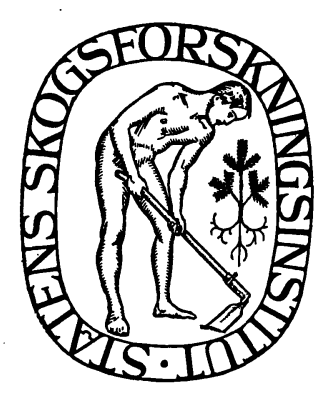

\title{
Introduction to Phyochorology of Norden
}

Nordens fyokorologiska grunddrag

by

STEN STURE PATERSON

\author{
MEDDELANDEN FR ̊N \\ STATENS SKOGSFORSKNINGSINSTITUT \\ BAND $50 \cdot$ NR 5
}




\section{Corrections to Description of the statistical computations by Olle Persson in Sten Sture Paterson: Introduction to Phyochorology of Norden}

Page

70 Line r2. Replace "have first been fitted graphically" by "have first been adjusted"

$7 \mathrm{I}-72$ In Tables 8-Io. For " $\Delta \mathrm{F}$ ” read "degrees of treedom"

73 Figure 27. Replace "The theoretical regression line" by "The regression line"

Line 6 from below. Replace "which are often fitted" by "which are often not satisfied"

74 Second column in Table II. The figure II means variable $\mathrm{y}_{1}$ 


\section{Preface}

The present work is an attempt to determine the timber producing capacity of the site by means of its natural conditions, particularly the features of climate. Investigations of this kind are of special importance for the evaluation of the potential productivity of areas lacking forests or where the forests have a structure rendering a direct determination of the productive capacity impossible. Research in this field may also strengthen our knowledge of the relationships between productive capacity and the natural conditions of the site.

In 1958 the International Union of Forest Research Organizations received a request from FAO to submit a statement concerning the method developed by St. St. PAterson for determining the yield potential of large forest areas. A working party under the chairmanship of Dr. J. Weck, professor of the Bundesforschungsanstalt für Forst- und Holzwirtschaft at Reinbek by Hamburg, was appointed with the object of studying the matter further. It was found most feasible to assign the treatment of various geographical regions to each member of the working party. Thus I received the task of investigating the problem as regards the Scandinavian countries and Finland.

The investigation is based partly on yield data obtained from the sample plots established by the Forest Research Institute of Sweden in virgin stands: and partly on yield data benevolently submitted by the forest research organizations in Denmark, Finland and Norway. On behalf of the Forest Research Institute of Sweden I want to express our sincere gratitude for the generous contributions made by our neighbour countries.

The material has been compiled by Dr. ST. St. PAterson who was employed by the Institute for the period Nov. Ist I959-June 3oth I96o and thereafter during shorter periods for complementary work. In the paper now presented he has reported on the investigation and its results.

Stockholm, March, I96r

Charles Carbonnier 


\section{LIST OF CONTENTS}

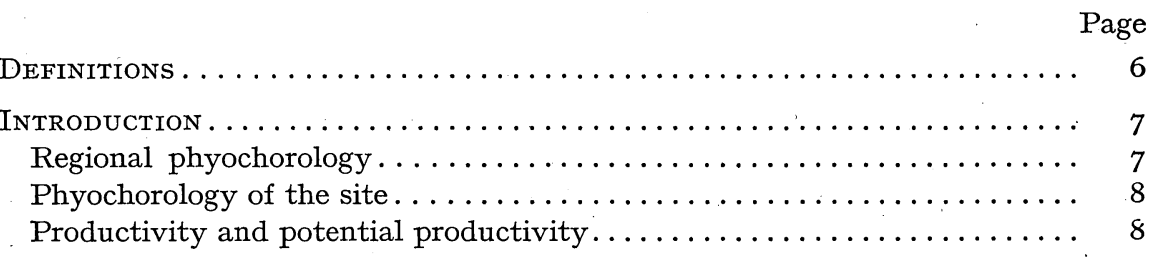

THE PLANT PHYSIOLOGICAL FEATURES OF FOREST PHYOCHOROLOGY . . . . . 9

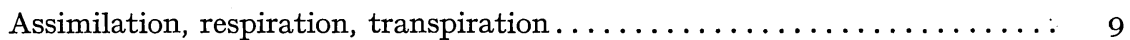

Carbodioxide assimilation ....................... Io

The plant physiological importance of light $\ldots \ldots \ldots \ldots \ldots \ldots \ldots$ ro

The plant physiological importance of temperature . . . . . . . . . II

The influence of solar radiation on the radial growth $\ldots \ldots \ldots \ldots \ldots \ldots$ I4

The influence of the annual temperature range on vigour . . . . . . . . I5

The influence of soil temperature on vigour $\ldots \ldots \ldots \ldots \ldots \ldots \ldots \ldots$ I7

The length of growing season and its influence on vigour $\ldots \ldots \ldots \ldots$

The importance of water for plant life $\ldots \ldots \ldots \ldots \ldots \ldots \ldots \ldots$ II

The occurrence of dry and arid periods within the area of investigation . . 23

The ombro-thermal regions of Norden $\ldots \ldots \ldots \ldots \ldots \ldots \ldots \ldots \ldots \ldots \ldots$

Hygro-thermal division $\ldots \ldots \ldots \ldots \ldots \ldots \ldots \ldots \ldots \ldots \ldots \ldots \ldots \ldots$ II

The MAterial of investigation $\ldots \ldots \ldots \ldots \ldots \ldots \ldots \ldots \ldots \ldots \ldots \ldots \ldots \ldots \ldots$

Forest data. ............................ 43

Yield data of the Swedish localities included in the investigation by Pro-

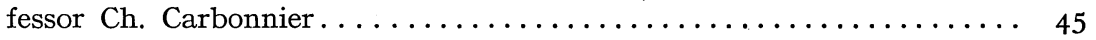

The meteorological material $\ldots \ldots \ldots \ldots \ldots \ldots \ldots \ldots \ldots \ldots \ldots \ldots \ldots$

Decrease in length of growing season at rising altitude $\ldots \ldots \ldots \ldots \ldots$

THE RELATIONSHIP BETWEEN CLIMATE AND FOREST YIELD .......... 6o

The plant physiological production balance................ 6 o

Photosynthesis and respiration in plant parts versus stands . . . . . . . 6 r

The investigation method concerning the relationship ........... 64

Report on the statistical computations by Mr. Olle Persson, Civ. Eng... . 69

The results of the statistical computations $\ldots \ldots \ldots \ldots \ldots \ldots \ldots \ldots$

Comparison with the potential productivity of other Nordic countries . . . 79

THE RELATIONSHIP BETWEEN SOME EDAPHIC FACTORS AND FOREST YIELD . . . . 90

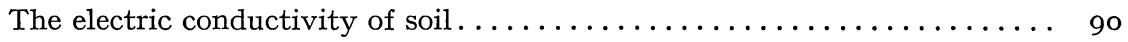

The influence of soil texture on the mean annual increment. . . . . . . 92

The influence of soil depth, depth of the humus cover and horizons . . . . . 93

The potential PRODUCTIVIty of NORdEn's forests $\ldots \ldots \ldots \ldots \ldots$

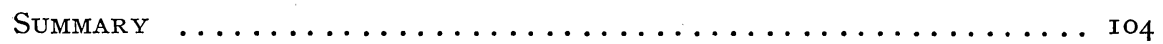

Sammanfattning (Summary in Swedish) $\ldots \ldots \ldots \ldots \ldots \ldots \ldots \ldots \ldots$ Io7

List of plates and illustrations $\ldots \ldots \ldots \ldots \ldots \ldots \ldots \ldots \ldots \ldots$ Iog

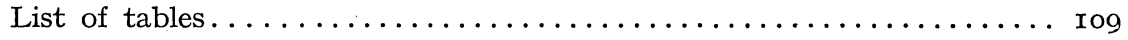

Published sources of information and literature used $\ldots \ldots \ldots \ldots \ldots$ I $\ldots \ldots$ 


\section{Acknowledgements}

Performing this research task, the author has enjoyed the opportunity of discussing arising problems with appropriate experts of the Forest Research Institute of Sweden as well as others. The author wishes to express his sincere gratefulness to the professors $\mathrm{CH}$. CARbonnier, E. Hagberg and C.-O. TAMM and to Mr. O. Persson, Civ. Eng. for their valuable comments on and critical scrutiny of this work.

Mr. A. Wiksten, MF. is responsible for the English translation, which was revised by Miss Juliet BlaIR. Maps and miscellaneous other exhibits have been drawn by Mrs. A. Neuschel. The tedious typing of tables etc. has been carried out by Mrs. J. KoltaI and Mrs. M. C. JosEPH. To all these persons the author is much indebted.

Stockholm, March, I96I

Sten Sture Paterson 


\section{Definitions}

Phyochorology,

Phyochor,

Solar radiation,

Isophyte,

Climato-isophyte,

Productivity, Potential productivity,

Dry period,

Arid period,
Gr. phyo-produce and choros-land; science of the ecology and the geographic occurrence pattern of areal production

land area with equal production potential and bounded by two isophytes

the total radiation energy received by the ground surface and comprising both direct and diffuse sunlight

line connecting places with equal growth potential

line connecting places with equal plant growth ability resulting from climate expressed by the CVP index (St. St. Paterson, I956, p. 8) production actually occurring a future, attainable production provided that certain conditions concerning the production factors are met with

(Germ. "Trockenzeit": Sw. "torrtid") that part of the year when the temperature $(t)$ curve in a climate graph is situated above the precipitation $(p)$ curve at the scale ratio $t=3 p$

(Germ. "Dürrezeit": Sw. "arid tid") that part of the year when the temperature curve in a climate graph is situated above the precipitation curve at the scale ratio $t=2 p$. 


\section{Introduction}

\section{Regional phyochorology}

In I955 J. WECK published his work "Forstliche Zuwachs und Ertragskunde" where he presented a mathematical expression of the climate in toto which was closely correlated with the average forest yield in Germany. Half a year later the present author submitted his paper "The Forest Area of the World and its Potential Productivity" where it was shown by means of the so called $C V P$ index that a similar globally valid aggregate expression of climate was closely correlated with the average forest yield. Although the papers were presented independent of each other, they both combine climate and areal production. The problem thereby assumes a distinct economical touch. The author is stressing this character by presenting a world map with phyochores exemplifying the silvan bio-effect of climate. The average timber production capacity expressed in cu.m. per hectare and annum can then be obtained directly.

The publication of the author's work in 1956 was followed by a discussion in which international experts seemed to agree (J. WECK, I957, I958; A. W. KüChler, I957; J. PARDÉ, I958, I959 a, and I959 b; F.A.O., I958, p. 25, f; C. J. Robertson, I958, and others) that the work provides interesting possibilities for an estimate of the sustained forest yield capacity and for probably valid comparisons (F.A.O. I958, p. 25) by means of values presented concerning the potential productivity of various regions. Among the critics are particularly those who question the method of omitting entirely the site factors (A. W. KÜCHLER, I957; E. RostLUND, I959). The reason for their standpoint seems to be that they make no difference between interregional investigations the mathematical basis of which is the mean value, and a detail investigation founded on individual data.

The interregional investigation attempts to construct a representative picture of the average yield capacity within each region specially separated. Each region is required to concur with a uniform area of production. Uniformity primarily pertains to the climatic conditions where the main body of the forest area is located. The method consequently requires a suitable regional division. The importance of this has been elucidated by the author's compilation of the forest yield values presented for Germany by WECK (I955, P. I24 ff) and their distribution by various areas. The climate factor has not been considered at the delineation of these areas since 20 per cent of the regions would appear directly unsuitable with regard to the $C V P$ index. If they are 
excluded from the material, the relationship between yield and CVP is strengthened from $r_{x y}=0.64^{1}$ to $r_{x y}=0.86$ (ST. St. Paterson, I957, p. $382 \mathrm{ff}$ ).

\section{Phyochorology of the site}

At the detail investigation the yield of the site constitutes the supplementary variable to the climate index applicable to the location. Each individual value used for both variables is absolute and concisely defined. This means that the influence of outside factors will affect the relationship to full extent. Consequently, variations in the edaphic conditions between various sites are expressed directly. Increased dispersion of data supporting the correlation is therefore a natural result. Simultaneously, the possibilities of studying the basic causes of this increase are improved as well as finding a mathematical expression thereof which can be combined with the climate index for the ultimate object of improving the correlation.

\section{Productivity and potential productivity}

It is of importance at phyochorological investigations of the kinds mentioned here to define closely the nature of the yield data supporting the compilation. Here it should be distinguished between productivity, which is expressing something actually achieved, and potentiality, which implies something possible in the future, assuming that certain conditions are met with. It should be stressed that the former expression will be the basis of the latter expression since productivity represents production values attained under ideal yield conditions. Local growth potential conditions are thus given regional validity.

The present investigation leads on naturally from the author's work of I956 with global aspects. The present work concerns the geographically delineated area of Norden ${ }^{2}$.

Leaving the large averages, we work instead with the individual data. By means of material now available it will be of special interest to investigate the extent to which the relationship previously found between climate and growth potential will prove valid. Attempts of improving the $C V P$ index further will also be made. In a later stage of the investigation it is tried to express the soil factor which is correlated with production in a way corresponding to that of climate.

\footnotetext{
1 According to E. STRIDSBERG (I958, p. 436) the correlation coefficient has erroneously been given the value 0.69 in the work cited.

2 In this work Norden includes Denmark, Finland, Norway, and Sweden. Iceland, also belonging to Norden, is here excluded.

3 In the following soil is used in the sense of loose soil layers; subsoil = uneffected mineral soils; and true soil (or solum) decomposed by influence of atmosphere, plants and animals.
} 
A combination of both variables, climate and soils, will then express the strongest relationship with the growth potential since they constitute the most important factors of production and the remaining contributory factors while chance will have a subordinate rôle.

According to the suggestion of the sponsor, the International Union of Forest Research Organizations permanent committee, on recommendation from FAO, the object of this investigation has been stated as "The study of site indices for determining the potential productivity of forests" (F. FIRAT, letter of March I8th, I959). The international research party appointed for this purpose has later through its chairman, Dr. J. WECK, formulated its task to "evolve a suitable index for determining the potential productivity of forests" (J. WECK, letter in March, I959). Thus the main research objects are partly to find a site index and partly to calculate the potential productivity of forest areas on the basis of this site index.

\section{The plant physiological features of forest phyochorology}

\section{Assimilation, respiration, transpiration}

The production of substance in the forests is governed by the plant physiological processes assimilation, respiration and transpiration (cf. H. Polster, I950). In terrestrial plants a close relationship exists between assimilation and transpiration since the processes occur by means of common canals of gas exchange (stomata), and between assimilation and respiration since the energy required for the metabolism of the assimilation products is produced by respiration (ibid. p. 74. f). At a given temperature assimilation is strongly dependent on light whereas respiration is mainly conditioned by temperature (ibid. p. 44). Transpiration requires supply of water and is also influenced by light according to the relationship with assimilation mentioned above.

For reasons of plant physiology meteorological data primarily concerning light, temperature and water supply are therefore of special interest. This was the standpoint of the author in 1956 (p. 46 and 68). The choice of climate data was then limited by the requirement that they should be available wherever meteorological records have been kept. Thus they were to consist of simple temperature and precipitation data. When the investigation comprises a limited region which is covered with a long established net of meteorological stations, it is reasonable to expect that considerably more detailed data on light, temperature and water supply are available. However, as shown in the following presentation, this is not the case. 


\section{Carbodioxide assimilation}

According to F. F. BLACKMAN (I905) the carbodioxide assimilation is composed of one photochemical process and a chemical process. Whereas the photo-chemical process is proportional to light intensity but independent of temperature, the chemical process, also called the "the Blackman reaction", is independent of light but increases with rising temperature. Assimilation is an interaction of these two processes (G. HYGEN, I939).

\section{The plant physiological importance of light}

A comparison between the curves representing the photosynthesis and respiration of the plants clearly shows how the carbohydrate balance of the plants is regulated by both these physiological processes. The intensity of the photosynthesis varies with light intensity and species. Among the species it is distinguished between light demanding species and shade tolerant species according to their capacity of maximum photosynthesis under various light conditions.

This makes it necessary to separate species with different light reactions, e.g. Norway spruce and Scots pine, at phyochorological investigations of detail nature, particularly if light is brought into the discussion as a special factor of production. The necessity of considering the influence of light on various species has been stressed e.g. by the LADEFOGED investigations (I956, p. 490) of the water consumption per sq. m. foliar surface of the trees. The water consumption of oak is $2 \frac{1}{2}$ times that of beech at approximately 80 per cent daylight and otherwise equal conditions, but equal at low light intensity (Io \%).

Light reaching the plants is composed of two kinds, direct and indirect light. Current meteorological observations are made at some Swedish stations only concerning the direct light. This is carried out by means of heliographs of various constructions, which register the duration of full sunlight. Expressions of the total light intensity and variations, however, are not obtained this way. The geographic occurrence and annual variations of the sunlight were treated by H. E. HAMBERG (I909), who developed a method of computing the number of sunlight hours from data on the basis of determinations of cloudiness collected at 3 rd class stations. By a method corresponding to that used by Hamberg for a presentation of cloudiness and frequency of sunlight on the Scandinavian peninsula it would be desirable also to elucidate the seasonal and regional variations of the light intensity. A basis for such a presentation is lacking, however, and thus it is practically impossible at present to develop a phyochorological relationship involving the factor of light. As a substitute we must use the general observation based on experience that the 
intensity of light is to some extent directly proportional to and correlated with temperature. The relationship between light intensity and temperature, however, varies with latitude as well as altitude. This further amplifies the rough approximation inherent in the substitution of a temperature value for the factor of light because of deficient material of observation in conjunction with bio-climatic relationships. The relationship between light intensity and temperature can be rather uniform only within a limited range of latitude with small altitudinal differences.

\section{The plant physiological importance of temperature}

Temperature belongs to the most well-known elements of climate. Various types of mean temperature values for Sweden have been presented by H. E. HAmberg (I908, I9I4, and I922) and A. AngSTröm (I938). The temperature value most suitable for plant physiological circumstances depends on the nature of the subject matter. The complex composition of the plant growth power means different temperature reactions for the various components. This can be studied by means of the utilization of the assimilation products in plants. Thus, the major portion of the assimiliation products are immediately used for growth at high temperature whereas low temperature mainly means a storage of the products (H. Polster, I950, p. 36). This also becomes obvious at a close study of the duration of e.g. the height and radial growth of the trees and their accumulation of stored nutrients. I. Hustich (I948) showed in his investigations of Scots pine in Finland that the height growth occurs in the late part of May and June in southern Finland and a month later in the northern parts of the country (ibid. p. 67). Radial growth is most vigorous in July (ibid. p. 66), foliage increment in July and in early August. In August the surplus of assimilation products are accumulated as stored nutrients. Other processes of differentiation in the cell division, too, are correspondingly tied to certain seasons. I. Hustich presented the following summary (p. 67): "During the first part of the spring the important generative processes occur while May-June is devoted to the cell elongation proper. July-August is the time for the cell differentiation and the formation and storage of reserve nourishments."

Earlier L. G. RoMELL (I925) carried out growth period investigations in Scots pine and Norway spruce. The observations made by S.-O. ANDERsson (I953), too, concerned the time of termination of the annual diameter growth in the same species. The results of these two investigations agree well with those presented by Hustich for Scots pine. The graphs published by Romell show that the strongest height increment in Scots pine occurs in May-June in southern Sweden and approximately ro days later in northern Sweden with respect to the initial stage. In Norway spruce the most intensive growth 
occurs in June and the first half of July in southern Sweden whereas the process is restricted to June in northern Sweden. The radial increment Romell found to be simultaneous with that of height, the former process, however, extending over a slightly Jonger period and reaching into the month of August. Romell's statement that shoot development and radial increment are initiated and terminated under the influence of entirely different factors (ROMELL, I925, p. I03) is remarkable in this context.

Diameter increment and its relationship with climate was also investigated by B. EKLUND (I957). He found the annual ring width variations in Norway spruce to be most strongly correlated with the number of days during the time May I6th-July 3Ist when the maximum temperature is at least $+\mathrm{I} 6^{\circ} \mathrm{C}$ $(r=0.72$, ibid. p. 24). Low temperature values for July-August exert influence by reducing the annual ring index in the next growing season (ibid. p. 53).

E. MoRK showed in his work (I94I) concerning the relationship between temperature and daily variations in the height increment of Norway spruce a remarkably strong correlation $(r=0.90 \pm 0.006$, E. MoRk, I94I, p. 83) between the temperature of the six warmest hours of the day and the height increment percentage (ibid. I96o, p. 235). He also stated good agreement between the curve for soil temperature at $2^{\circ \circ} \mathrm{P}$. M. at a depth of $10 \mathrm{~cm}$ and that for the height increment percentage (ibid., p. 52).

The various physiological processes affecting or influencing the volume increment of trees apparently represent a complex set of factors greatly varying in heat requirements with time. The volume increment is a suitable aggregate expression of the interaction of these factors. The relationships between the volume increment and the increment of height and diameter, and the temperature value of July treated by I. Hustich in I948 (p. 66), have been used as a basis for the following table. It should be noted that data pertain to Scots pine in northernmost Finland.

Table I. The correlation between radial growth, growth in length, growth in cu. $\mathrm{m}$. of the pine in Utsjoki-Enare and the mean temperature in Sodankylä

\begin{tabular}{|c|c|c|c|c|}
\hline & $\begin{array}{l}\text { Growth } \\
\text { in length }\end{array}$ & $\begin{array}{l}\text { Radial } \\
\text { growth }\end{array}$ & $\begin{array}{l}\text { Cubic } \\
\text { growth }\end{array}$ & $\begin{array}{l}\text { July } \\
\text { temp. }\end{array}$ \\
\hline Growth in length........ & - & $0.09 \pm 0.22$ & $0.72 \pm 0.1 I$ & $0.23 \pm 0.2 \mathrm{I}$ \\
\hline Radial growth.......... & $0.09 \pm 0.22$ & - & $0.63 \pm 0 . r_{4}$ & $0.86 \pm 0.06$ \\
\hline Cubic growth.......... & $0.72 \pm 0 . x x$ & $0.63 \pm 0.14$ & - & $0.6 \mathrm{I} \pm 0 . \mathrm{x}_{4}$ \\
\hline July temp............ & $0.23 \pm 0.2 \mathrm{I}$ & $0.86 \pm 0.06$ & $0.6 \mathrm{I} \pm 0 . \mathrm{I}_{4}$ & 二 \\
\hline
\end{tabular}

It is rather surprising that the good correlations between volume increment and height increment, and between volume increment and radial increment are no higher. The determination coefficient $\left(r^{2}\right)$ in the two cases is 0.52 and 0.40 , respectively, which means that the variance of volume growth is deter- 
mined by the variance of height and increment to an extent of 50 per cent and 40 per cent, respectively. The fact that no relationship between length increment and radial increment can be reported $(r=0.09 \pm 0.22)$ may be considered a vindication of the ROMELL statement, cited above, that the two increment processes are influenced by entirely different factors. While HusticH's measurements of the height growth were made on the shoots of the branches, the terminal leaders were measured by RoMELl (Norway spruce and Scots pine) and MoRk (Norway spruce). This difference in measurement technique clearly affects the results. Thus, Hustich found no appreciable relationship $(r=0.23 \pm 0.2 \mathrm{I})$ between height increment and July temperature, whereas MoRk (I94I, p. 52) was able to present a very strong correlation between increment and the mean temperature of the six warmest daily hours of the entire growing season, as well as that of July. The difference between the temperature values obtained by these two research workers, however, may not play any major rôle in this context. Mork (ibid., p. 73) arrived at the conclusion that the monthly mean temperature of the six warmest hours of the day closely agrees with the monthly mean value of temperature at $2^{\circ \circ} \mathrm{P}$. M. Since the latter value approximately equals the maximum temperature of the day, we can consider the statement of O. LANGLET (I935, p. 396 ff) that monthly mean values of the daily mean temperature and those of extreme temperature values exhibit a nearly, complete correlation. It is difficult to evaluate the importance of the difference in geographical location between the Hustich and the Mork areas of observation. A compilation of the observations of Romell, Hustich, and Mork seems to reveal no probable reasons for assuming that the difference in localities of observation should be of importance in this context. If the Hustich observations from a boundary forest region are applicable to a locality with more favourable climate, the conditions found by Hustich and Mork may indicate that the extension of branches and the height increment are influenced by entirely different factors. Thus, the importance of light for the height increment has been indicated by W. TRANQUILIINI (I959, p. I35), who found that increase in the height growth of Pinus cembra at an age of 25 years is a stimulus reaction caused by a reduction of the light supply in the densely and selfshading crown developed at that age.

The previous argumentation shows that an equalization of the responses of various species should be avoided in studies where height, length and volume growth are involved. This also pertains to Scots pine and Norway spruce as shown in the Romell investigation cited and in the analyses made here of the results obtained by Mork and Hustich. Detailed analyses of phyochorological work must consequently be treated separately for each species to produce satisfactory results and the dependence of primarily height and diameter growth on temperature should be closely investigated. According to 
HusticH's investigations, the volume growth appeared to be most strongly correlated with the height growth (0.72 $\pm 0 . \mathrm{II})$ and slightly more weakly with the radial growth (0.63土0.I4) and the July temperature (o.6I $\pm 0 . \mathrm{I} 4)$. Simultaneously, the relationship between the height growth and the July temperature was very weak (0.23 $\pm 0.2 \mathrm{I}$ ) but noticeably strong between the radial growth and July temperature (0.86土0.06). In agreement with the previous discussion, these correlation conditions show that the volume growth produced at a certain site is a function of a radial growth heavily influenced by temperature and a height growth presumably regulated by a climate factor varying with the species. Light is probably this factor for Scots pine and temperature for Norway spruce. E. MoRk provided evidences for the dependence of height growth of Norway spruce on temperature by presenting a close relationship between the six warmest hours of the day and the height increment percentage on fresh-moist sites with the correlation coefficient 0.855 . The relationship is weaker on dry sites due to insufficient moisture.

\section{The influence of solar radiation on the radial growth}

Associated problems were elucidated by TH. Wilhelmi (I959) in a work concerning the radial increment and its dependence on the solar radiation (direct + indirect light) and air temperature. The observation that the curves of solar radiation and temperature represented by relative numbers cross each other in the middle of the growing season seems to be most significant. Exhibiting high values during the first half of this time period, the solar radiation decreases rapidly during the latter half whereby its curve is changing position in relation to the temperature curve (Fig. I). Wilhelmi explained this by the maintenance of temperature at a high level during the latter half of the growing season by wind-born heat supply. This, however, can only be a part explanation. Studying the radiation curve, we find it to climb rapidly in spring and early summer; it declines more rapidly in the middle of the growing season (mid-July) subsequently to descend slowly and nearly congruently with the temperature curve. This course is probably closely associated with the distribution of precipitation during the growing season. At Reinbek spring has deficient precipitation in relation to other seasons. Abundant precipitation is recorded toward the end of June and in July, which means a large increase of cloudiness in relation to that in spring, i.e. a decrease of light in addition to that caused by the passing of summer solstice.

According to the changes of climate, this inversion of the relationship between the relative values for temperature and solar radiation indicated by Wilhelmi may be expected to occur at various occasions, varying strength, or fail to appear altogether. It must be considered an urgent task for re- 


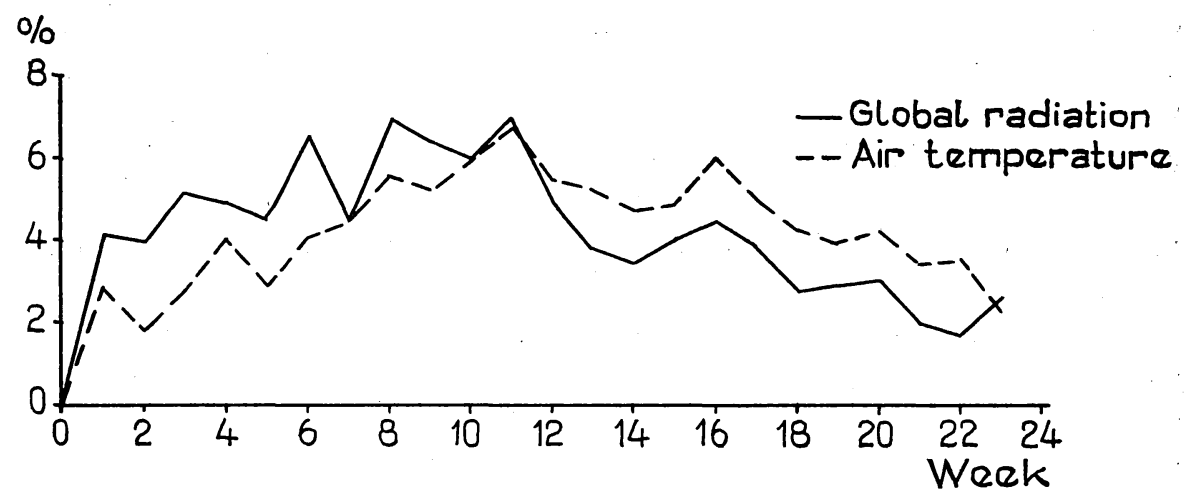

Figure I. Solar radiation and weekly mean temperature of air in per cent of the total value of the growing season of 1957 .

search in this field to enable a delineation of regions with equal temperature-light relationships by intensified collection of material. This would provide an opportunity to explore the potential specific features of the various species in their requirements concerning the factors discussed. It would be possible after such a delineation to incorporate for each species the results obtained into a bioclimatic regional division of the kind tried by the author in 1959 for forest cover types in general. A big step forward would then be taken toward a more definite knowledge of the formation of assimilated products and wood, which are two processes according to Wilhelmi (p. 209): "Zwei voneinander zu trennende Prozesse, die miteinander wohl verbunden sind, deren einer aber von Strahlung und Temperatur abzuhängen, deren andere nur temperaturbedingt zu sein scheint."

The influence of the annual temperature range on vigour

Ignoring the annual variations in the bioeffect of climate and their importance for the special plant physiological processes expressed in height (length), diameter and volume increment, accumulation of nutrients etc., it can be concluded on the basis of the present standpoint of research that the temperature of the warmest month during the standard period $\left(T_{v}\right)$ is the best and most easily available expression of the influence of the temperature climate on the forest growth power. The effect of the mean temperature of the warmest month, however, is dependent on the preceding and succeeding development of the vegetation. The temperature amplitude $\left(T_{a}\right)$ here enters the picture as an important factor. It expresses the range between the mean temperature values of the warmest and the coldest months of the year. The 
daily amplitude will not be used in this context since its influence seems to change from positive to negative. Thus, a small daily amplitude in climate with equal daily temperature and in one case equal length of day and night is expressing an inferior balance of substance production, but a superior balance in the second case with light during the main part of the day. The variability of the magnitude of nightly respiration with the conditions discussed is a reason for this.

According to the definition, the annual amplitude can have a minimum value of zero, i.e. the mean temperature values of the warmest and the coldest months are equal. In this situation $T_{v}$ is an expression of the most growth promoting temperature climate occurring within the equatorial regions. The ratio $\frac{T_{v}}{T_{a}}$ is then infinite. As the $\mathrm{T}_{a}$-value rises this ratio steadily decreases toward fractions of digits thus indicating the growth potential decreasing influence of the winter cold. If the mean temperature of the coldest month $\left(T_{k}\right)$ had instead been used in this case, the result would have been entirely different. At equal values of $T_{v}$ and $T_{k}$, i.e. equatorial conditions, the ratio equals one. If an example is taken for comparison from a temperature region where $t_{v}=\mathrm{I} 6^{\circ} \mathrm{C}$ and $T_{k}=\mathrm{I}^{\circ} \mathrm{C}$ are commonly associated temperature values, the ratio becomes sixteen times that obtained in the first example. This would mean a temperature climate in the temperate region more suitable for plant growth than in the equatorial regions.

This complex of matters has previously been discussed by the author, who then presented the following view points (ST. St. Paterson, I957, p. 384): "The higher the ratio $\frac{T_{v}}{T_{a}}$ the more even and higher is the heat supply during the year. In Germany $T_{a}$ varies between $I 6^{\circ} \mathrm{C}$ and $20^{\circ} \mathrm{C}$ whereas $T_{v}$ simultaneously changes but slightly, thus the ratio $\frac{T_{v}}{T_{a}}$ may be considered nearly constant. This explains why $T_{a}$ lacks importance according to Weck. In Sweden, however, $T_{a}$ fluctuates between the values $\mathrm{I} 7^{\circ} \mathrm{C}$ and $27^{\circ} \mathrm{C}$ (in the present material between $16^{\circ} \mathrm{C}$ and $29^{\circ} \mathrm{C}$, author's remark) and is associated with corresponding magnitude of differences between $T_{v}$ values for the extreme stations ( $10^{\circ} \mathrm{C}-\mathrm{I} 8^{\circ} \mathrm{C}$, author's remark). This will be still more accentuated in Soviet Asia, where $T_{a}$ varies between $23^{\circ} \mathrm{C}$ and $65^{\circ} \mathrm{C}$ and $T_{v}$ between $4^{\circ} \mathrm{C}$ and $32^{\circ} \mathrm{C}$. It is logical that the temperature ratio must decrease at increasing latitude and deepening continental situation as shown by the examples. We need only consider the heat quantities used in spring for the smelting of snow masses and thawing of frozen soil, i.e. heat otherwise available for plant growth." (cf. also F. LAUSCHER, I958, p. IO2.) 
The influence of soil temperature on vigour

Water and precipitation in solid form have great importance for growth power by releasing or binding large amounts of heat. Associated effects influence both air temperature and in a still larger extent soil temperature. The latter temperature has a direct and strong influence on the length growth of plant roots. The comprehensive investigations by K. LADEFOGED (I939) showed that the length growth increases according to a geometrical sequence between $2{ }^{\circ} \mathrm{C}$ and $14^{\circ} \mathrm{C}$, after an arithmetic succession between $\mathrm{I} 4^{\circ} \mathrm{C}$ and $24^{\circ} \mathrm{C}$ finally to culminate at $26^{\circ} \mathrm{C}$. The maximum mean soil temperature in Sweden at a depth of $20 \mathrm{~cm}$ is approximately $16^{\circ} \mathrm{C}$, in northernmost Sweden at Kiruna not even $10^{\circ} \mathrm{C}$ (A. AnGSTRöM, I946, p. 54). The main part of the country is consequently characterized by low soil temperature values that only exceptionally and for a short time of approximately one month reach the values most inductive to root growth. Root hairs are the tree organs most effectively absorbing water; occasionally mycorrhiza may be more important. Since their development is associated with the root growth, the relationship between the transpiration flow, i.e. the means of nutrient transport and the temperature regulator of the plant, and photosynthesis is clear.

Although sufficient material is lacking for a close investigation of the relationship between soil temperature and $\frac{T_{v}}{T_{a}}$, conclusions regarding the existence of such a dependence can be drawn logically. The relationship is strengthened as well as that with the growth potential if a factor describing the slope of the temperature curve at the annual flection between the turning points that define amplitude is added to the previous ratio. The range of the curve located above the temperature limit and expressing the lowest heat supply necessary for the existence of plants is then of particular interest. The factor sought is an expression of the length of the growing season.

\section{The length of the growing season and its influence on vigour}

The growing season is a term to be defined flexibly. Definition will change according to the character of investigation and the special view points attached to what shall be considered a plant physiological limit of the beginning and the end of the growing season. From a forestry point of view it may here be preferred to choose the time when the root activity is noticeable, time between bud bursting and leaf fall or between flowering and leaf fall. It is more difficult to establish the growing season according to the time when the basic life processes, photosynthesis, respiration and transpiration occur. Although these 
processes should logically constitute the safest basis, they cannot be used since they occur also during winter under certain conditions. This has been stated by e.g. L. IWANOFF (I924) in his classical work concerning the winter transpiration and by R. O. FREELAND (I944) in a study of photosynthesis and respiration.

Apparently, the principles for the computation of the growing season vary greatly. Here, only some examples will be mentioned:

E. A. MitscherLich found (I933) that the plants require a mean temperature of minimum $+5^{\circ} \mathrm{C}$ for their growth during the growing season.

K. RUBNER stated (I934) a close coincidence of the timber line and the 6o-day isotherm for $10^{\circ} \mathrm{C}$. These values have then been used as base minimum values for the heat requirements of forest trees as well as for the length of the growing season. Exceptions are the alpine areas, where these values are lower due to the increased importance of the solar radiation temperature at rising altitude.

A. ÅngstRöm (I946) considered the time of the year during which the mean daily temperature exceeds $+3^{\circ} \mathrm{C}$ to constitute the growing season. This temperature value was chosen on account of its close agreement in time with the start of spring farming and the end of autumn farming.

W. LAuer (I952) developed E. DE Martonnes aridity index of I926 for areas with arid season (s) to elucidate the moisture conditions of the individual months. The growing season thus comprises an aridity index of 20 , the latter value is computed from the function $i=\frac{\mathrm{I} 2 p}{t+\mathrm{IO}}$, where $p$ is the mean monthly precipitation and $t=$ the mean monthly temperature.

Scrutinizing the Rubner values described above, A. Austin Miller found superior agreement between the timber line and the isoline suggested by A. F. Schimper for the months exceeding $+6^{\circ} \mathrm{C}$. This value has subsequently been used for a computation of the minimum requirements of various forest types with respect to the length of the growing season.

F. BAGnouls and H. Gaussen (I953) and successors found the relationship $P \leq 2 T$ agreeing with the plant ecological conditions to indicate an arid month $(P=$ precipitation, $T=$ temperature, both factors pertaining to monthly mean values). The growing season will then comprise the number of months when $P>2 T$.

A large number of additional methods of computing the length of the growing season have been presented. Among the wellknown ones are those developed by C. W. Thornthwaite, D. Szyemliewics, C. H. Merriam, L. Emberger and A. Giaccobe. A closer discussion of these methods, however, would be superfluous in this context. Summary descriptions of works in this 
field are presented by L. EMBERGER (I955) and perhaps most comprehensively by K. KNOCH and A. Schulze (I954).

In the CVP index suggested for global aspects (I956), the author used two different, mutually supplementary systems for a determination of the length of the growing season. Depending on the minimum factor with respect to vegetation (heat or water), either the temperature limit of $+3^{\circ} \mathrm{C}$ developed by Ångström and cited above, or the Martonne-Lauer method of compiling the aridity was used. Furthermore, a minimum growing season of two months with a minimum mean temperature of $+\mathrm{IO}^{\circ} \mathrm{C}$ according to Rubner was required (cf. St. St. Paterson I956, pp. 93, 98, Ior, I02, I03, I06 a.s.o., foot note I and map, Fig. I7, p. I08). The work published by the author also showed " that a growing season of at least three months is necessary to make it possible for forests to exist at the border of the dry desert" (ibid., p. I83).

Reviewing the author's work of I956, J. Weck wanted to define the growing season according to Rubner $+I 0^{\circ} \mathrm{C}$ as follows (J. WECK, I957, p. 224): "Zur Vegetationszeit zählen die humiden Monate, woweit sie die Mindestdurchschnittstemperature von $+\mathrm{IO}^{\circ} \mathrm{C}$ erreichen: die Mindestvegetationszeit für Entwicklung und Dauer natürlicher Wälder beträgt 2 Monate." - According to a definition suggested by J. PARDÉ (I958, p. 20I; I959, p. 50) and based on the conditions prevailing in France the growing season is defined as follows:

" $I$ ' en zone non méditerranéenne, de compter comme mois de végétation active ceux pour lesquels la température moyenne mensuelle est d'au moins $7^{\circ}$;

$2^{\circ}$ en zone méditerranéenne, de porter cette limite inférieure à $\mathrm{IO}^{\circ}$, en défalquant de plus les mois pour lesquels la pluviosité en $\mathrm{mm}$ est inférieure à deux fois la température moyenne mensuelle en degrés centigrades."

Due to the detail character of the present work, the author has aimed at finding the most accurate material possible for further compilation. From this point of view, months are too crude time units for measuring the length of the growing season. A measurement in no. days would be desirable. An extraordinarily good method of computing the no. days is available in the climate graph developed by $\mathrm{H}$. Walter and in summarizing investigations by Bagnouls-Gaussen, Seljaninow and Walter (H. WALTER, I955). The number of days comprised in the growing season can here be obtained graphically whether thermally or hygrically limited.

The matter of choosing temperature most suitable for the computation of the number of days now remains. Methodically, the choice is determined by the covariable of temperature brought into the picture. A literature review shows that the most commonly used covariable has been based either on various 
kinds of plant ranges or on different kinds of fenological observations. Both methods have their disadvantages.

Concerning plant ranges there is a great inaccuracy in ascertaining the border lines since one is dependent on the current conditions. The conditions, however, need not represent the virgin state of nature but can be more or less influenced by man and animals. Thus, a relationship between such a boundary and a temperature value is not true but variably depending on chance.

Concerning the externally visible stages in the annual rhythm of vegetation which constitute the phenological observation material, the weaknesses are entirely different. As a variable we select one certain part process of the large complex of plant life. Our observations will pertain to a detail of plant growth of which we are unable to say definitely whether it expresses the most feasible relationship with the growing season. We need an expression of this time which is closely related with some general status of physiology.

In his studies of the relationships between climate and the physiological variability of Scots pine, O. LANGLET (I936) produced results, which are very interesting in this context. Using 39 Scots pine strains for which normal values of dry matter content had been determined, this worker found the best relationship with the number of days with $+6^{\circ} \mathrm{C}$ and $+8^{\circ} \mathrm{C}$ when comparing dry matter content and various temperature values. The number of days with higher and lower temperature values displays greater dispersion. According to Langlet, the choice between $+6^{\circ} \mathrm{C}$ and $+8^{\circ} \mathrm{C}$ is unimportant but he simultaneously stated that $+6^{\circ} \mathrm{C}$ better agrees with "the presumptive growing season" of the conifers (O. LANGLET, I936, p. 340, ff).

Resting on physiological reasoning, this temperature value of Langlet agrees with corresponding, differently calculated temperature values suggested by J. Pardé $\left(+7^{\circ} \mathrm{C}\right)$ for non- mediterranean regions and by A. F. Schimper $\left(+6^{\circ} \mathrm{C}\right)$. The author has therefore settled on $7^{\circ} \mathrm{C}$ as a limiting value for computing the length of the growing season. Moreover, the growing season must comprise at least three months with a mean temperature of $+6^{\circ} \mathrm{C}$. It should be noted, however, that this temperature value is calculated on the basis Scots pine material. It must therefore be assumed vaguely that the same physiological temperature reactions occur in Norway spruce and birch, which are also represented in this material.

The determination of the length of the growing season has been carried out by means of the climate diagram designed by $\mathrm{H}$. Walter and discussed above (p. I7). Such a climate diagram has been constructed for each meteorological station presented in Tab. II, a total of 467 . For reasons of limited space all of these have not been included here but are found on the sheet "Northwestern Europe" in "Klimadiagramm-Weltatlas" (Climate diagram-World Atlas) under edition by $H$. WALter and H. Lieth. One graph only, I4I 


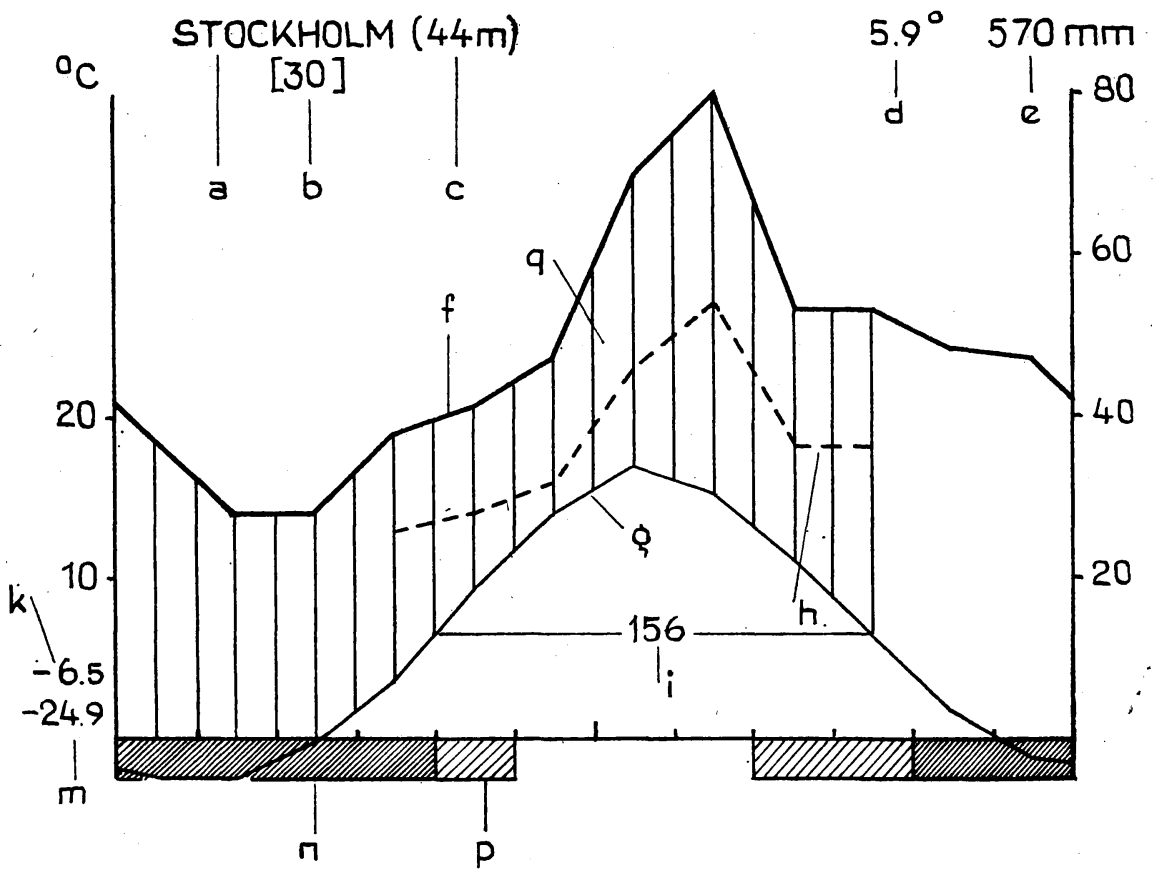

Fig. 2. Climate diagram of Stockholm. Design pattern of a climate diagram. The letters stand for:
$\mathrm{a}=$ station
$\mathrm{b}=$ no. years of observation
$\mathrm{c}=$ altitude
$\mathrm{d}=$ mean annual temperature $\mathrm{e}=$ mean annual total of precipitation $\mathrm{mm}$ in ${ }^{\circ} \mathrm{C}$
$\mathrm{f}=$ mean monthly values of
$\mathrm{g}=$ mean monthly values of temperature
$\mathrm{h}=$ precipitation curve in the
$i=$ growing season (no. days), Figures below scale of $\mathrm{I}: 3\left(\mathrm{I}^{\circ} \mathrm{C}=3 \mathrm{~mm}\right) \quad$ as $\mathrm{T} 25$ (Io) mark dry and arid period,
$\mathrm{k}=$ mean minimum of the respectively coldest month
$\mathrm{m}=$ absolute minimum
$\mathrm{n}=$ month with a mean minimum temperature below zero centigrades
$\mathrm{p}=$ month with absolute minimum below zero centigrades
$\mathrm{q}=$ humid period

Stockholm, is shown (Fig. 2) for a description of its contents and the practical procedure used when the length of the growing season has been determined.

\section{The importance of water for plant life}

Water is the last of our three factors presented as important for plant life. The importance of transpiration for the production of substance and the relationship between carbodioxide intake and transpiration has already been stressed in the introduction to this chapter against the background of both 
processes having common gas diffusion canals. Water furthermore constitutes the solvent for soil nutrients; it carries the assimilation products within the plant; it protects the organs of photosynthesis against damaging high temperature caused by heavy solar radiation, by releasing heat at the transpiration process, and it participates directly in the assimilation process since the formation of a carbohydrate molecule requires the presence of two molecules of water (E. C. WAssink, I956, p. 295).

The consumption of water is different in various plants and plant cover types. Moreover, one plant individual has the capacity of adapting its water requirements within certain limits, particularly with respect to temporary changes in the relationship between temperature and precipitation. Certainly, a genetical adaptation of the plants to their environment is the background of these circumstances. The natural water balance in vegetation has been subject to special investigations by e.g. K. LADEFoged (I956), O. STOcker (I93I, I933, I935, I956), M. G. StÅlfelt (I934, I935, I956) and H. WALter (I939). Similar studies carried out by A. Pisek and E. Cartellieri (I93I, I932, I933, I939, I94I), U. Berger-LANDEFELT (I935), M. Henrici (I937 ff) a.o. have had a more regional (Landschaft) ecological character. The figures presented regarding the requirements of the plant cover all lack accuracy with respect to the absolute figures, but as a basis of relative values they provide a good picture of the mutual magnitude (cf. P. FilzER, I95I, p. 82, ff).

The supply of water is better known than the plant consumption of water. The measurements of precipitation carried out at the meteorological stations are our most common source of information in this respect. This information is very important since it describes the hygrometric character of a region and thus also the shaping of plant cover types. Growth potential increases with rising precipitation to a certain upper limit, where additional humidity. has an opposite effect. It will then be questioned whether this influence on the growth potential is caused by the total annual precipitation or by certain parts thereof. This point may be elucidated and the following circumstances must be considered in particular: the length of the growing season, the ombrothermal situation and the condition and availability of the soil water reserve for plant growth during the same period of time. The length of the growing season varies for different plants. The possibilities of utilizing the soil water reserve during dry periods by means of the capillary movements are greater for a plant cover with deep root system than for plants with a shallow root system, cf. K. LADEFOGED, I956. Generally, too, the perennial plants are more dependent on the annual precipitation, which regulates the water table, than are the annuals, which are presumably most dependent on a certain period of precipitation. The level of the water table at various times is decisive in this context. Under ideal conditions this level is always sufficiently high to con- 
stitute a reserve of water. Simultaneously good drainage will prevent this soil water from becoming too high and detrimental to the respiration of the roots. The ideal situation, however, is rather uncommon in nature. Variably large fluctuations occur both as an annual rhythm and as temporary disturbances on account of e.g. abnormal rainfall or total deforestation within an area.

Both the annual precipitation and the precipitation during the growing season are consequently of importance from a silvan point of view. Considering purely Nordic conditions with current regional changes in the hygrometric climate, we find two different regions. The larger one is characterized by precipitation in sufficient amounts for plant growth during all the months of the year. The smaller region extends along the coast of the Gulf of Bothnia touching the Aland area when passing into the Baltic Sea and continuing southward along the coast all the way to the point of Falsterbo, swinging over on the south side of the isle of Sjaelland and northward along the strait of Stora Bält, further along the east side of Jylland finally to peter out at Læsö. Fig. I 8 shows it to be a narrow coast zone in one point only reaching a width sufficient to enclose the isles of Gotland and Öland. From a hygrometric point of view this zone is characterized by such low values of precipitation in relation to temperature during a variable part of the first half of the growing season that drought occurs.

\section{The occurrence of dry and arid periods within the area of investigation}

The ombro-thermal curve relationship such as presented in the $\mathrm{H}$. Walter climate diagram has served as an indicator at this regional division. This is primarily based on the observation made by $\mathrm{H}$. GAUSSEN within the mediterranean area that plant growth enters into dormancy because evapo-transpiration exceeds precipitation. This results in drought as soon as the ratio of temperature when doubled exceeds precipitation (cf.Fig.2). Seljaninow has shown for eastern Europe that a change of the ratio to I: 3 produces the limit between the humid forest region and the dry forest steppe (H. WALTER, I957, p. $224 \mathrm{f}$ ). The scale ratios express two degrees of drought both of which are termed separately in the German language. "Dürrezeit" thus is the extreme drought season, whereas "Trockenzeit" is a moderate drought. An adequate translation of these German terms to Swedish and English is difficult since no corresponding words can be found. The author, however, will here use the word arid in the meaning of "dürr" and dry for "trocken". In the English text "Klimadiagramm - Weltatlas" H. WALter and H. Lieth use the expression arid in the same sense as that suggested here, but no translation is given for "trocken". Consequently arid is strictly defined on ombro-thermal basis. 
According to the previous discussion, we may state that an ombro-thermal climate type corresponding to that of the forest steppe occurs within Norden. The drought season occurs in summer. In the extreme north of the Gulf of Bothnia the drought season occurs in July but is advanced with southerly latitude to comprise the month of June and even parts of May as at Falsterbo and Denmark. Small areas with drought period occur locally in Norway and in one location, Ulstad, even with arid spells. The dry locations in Norway are situated in the innermost parts of the fjords or in deep valley bottoms where high mountains deflect precipitation. The village of Lärdal, at the innermost Sognefjord has a drought period beginning in April and ending no sooner than July, i.e. a total of Io8 days. This is the longest drought season recorded in the Nordic countries. It usually amounts to maximum I $1 / 2-2$ months (yet, Hoburg on the isle of Gotland has $8 \mathrm{I}$ days, Ulstad in Norway 87 days and Kysthospitalet in Denmark 97 days). The map on p. 40 shows the number of days included in the drought period at the stations concerned.

The knowledge of the length of the drought period and its geographical location puts the relationship concerning the water management in forests in an informative light. The thermally determined growing season appears to be an insufficient definition of the time factor when included in a mathematical expression of the growth potential. A drought period, which occurs like here during the growing season, means a deficient supply of precipitation in the forest. If this deficit is not compensated, the growth will be reduced, i.e. yield lowered. The only possibility for the trees to cover their demand for water in a situation like this is a supply of either capillary soil water or of a reserve of free soil water. Both these types of water supply can consequently prevent a reduction of the growth potential caused by a drought period. The relationship between the length of the drought period and the amount of capillary water and free soil water will here be decisive. The importance of the capillary soil moisture for plant growth is great, which has been elucidated e.g. by H. HolsteneR-JørGENSEN's investigations (I955, I956). The discussion between him and C. M. MøLlER (I956), E. OksBJERG (I956) and M. G. STÅLfElT (I956) further shows a complicated relationship between the capillary water and the free water as influenced e.g. by the vegetative cover, soil texture, humus content and layer density. The argument indicated the necessity of continued research efforts in this field. Special importance is here attached to the amount and duration of the capillary supply of water under the influence of an ombro-thermal drought period. A methodically important contribution to our knowledge of the water consumption of the trees and its dependence on light, air humidity, wind, temperature and soil moisture was furnished by K. Ladefoged (I956). He showed 
e.g. how a sufficient amount of water for the trees in clayey, sandy and gravelly soils was consumed so rapidly after about three weeks in a drought period that the water intake decreased by 38 per cent on clayey soils and 44 per cent on gravelly and sandy soils for beech, by 67 per cent on gravelly and sandy soils for oak and by 59 per cent on clayey soils for ash (K. LADEFOGED, I956, p. 499).

As stressed in an other context, special attention must be paid to the seasonal changes in the water table when estimating the forest yield conditions of a site within the region of the drought period. Features such as topography, soil composition, depth of the soils and distance to the bedrock are influential in addition to precipitation.

Improved knowledge of the free soil water conditions therefore requires field investigations within the areas concerned. To elucidate the set of problems generally, it may be mentioned that the precipitation recorded prior to the drought period closely affects the supply of free soil water. Connection with humid areas by a variably developed system of rivers also has an influence.

Considering the conditions in Norden the following observations may be discussed here.

The longest drought periods in Denmark occur on the isle of Bornholm, in northwestern Sjælland, on the isles of Anholt and Læsö. The growing season there varies between I77 and I87 days, one seventh to half of which is drought period (27-97 days). In the extreme case, Kysthospitalet, Fig. 3, with a growing season of 186 days and a drought period of 97 days, this means reduced growth potential conditions from an ombro-thermal point of view from the beginning of the growing season to the month of August. Low values

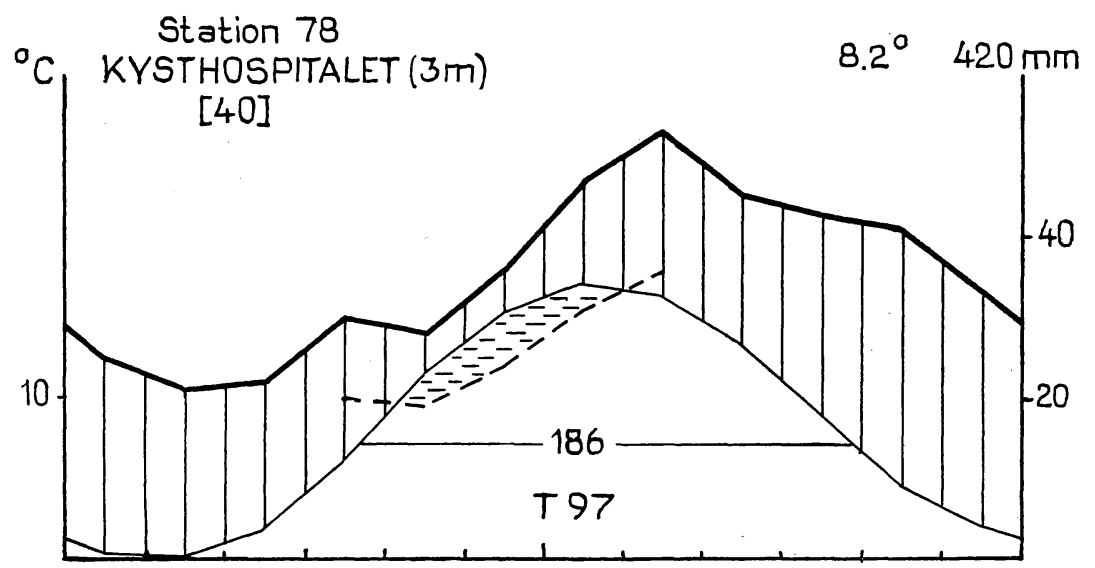

Figure 3. Climate diagram for Kysthospitalet, Denmark. 
of precipitation (between 20 and $30 \mathrm{~mm}$ ) occur earlier in the year and only November and December present slightly higher values, $4 \mathrm{I} \mathrm{mm}$ and $33 \mathrm{~mm}$, respectively. Moreover, the mean temperature of the coldest month is above $\mathrm{O}^{\circ} \mathrm{C}\left(+0 . \mathrm{I}^{\circ} \mathrm{C}\right)$.

No long lasting disturbances thus occur in the natural circulation of water by storage of moisture in the forms of snow or ice (frost). Sudden changes between periods of frost and thaw in winter may possibly cause increased surface runoff. The moderate rise of the water table in the autumn is consequently reverted during February or March to become normal at the beginning of the growing season, which means a low reserve of free soil water. The long drought period (over three months) will therefore exert a strong influence on the forest growth.

Although more moderately expressed, similar conditions are also encountered within other parts of the drought region, which surrounds Jylland almost entirely. Since we deal with mean values comprising 40 years, the delineation cannot be considered accurate but more of a centre line in a fluctuating boundary zone. The whole of Denmark is consequently exposed to the risk of years with variably long drought periods to a considerably greater extent than are regions situated farther away from the drought region.

To elucidate this matter, we will select two stations, one at Askov within the region in Denmark with the highest rainfall, and the other at Hammershus, belonging to the areas most typical for this drought region. We shall study the annual fluctuations of the ombro-thermal conditions for each station by drawing a number of climatograms (cf. H. WALTER, I955). Thus, we will investigate the extent to which drought periods affect the more humid station and how often they fail to appear where they are expected to occur normally.

The climate diagram for Askov (Fig. 4) gives the picture of an average climate with distinct humid conditions. Although spring has the lowest precipitation, it still has rainfall sufficient to provide a good margin over the limit of drought period. Details behind the 40-year mean values, however, exhibit rather frequent changes in the ombro-thermal conditions. This is shown in Fig. 5 by the climatogram for each of the years IgI6-I925 comprising a randomly selected Io-year span during the basic period I886-r925. Of the ten climatograms only one, that for I923, shows no drought period. Nearly similar is the year of I9I6, which has a drought period for almost a week in September. The remaining eight years all show a drought period as well as an arid spell of variably serious extent. The severest drought occurred in I92I when it comprised 96 days (63 of which arid) of the I95 days of growing season. The extent to which the soil water and free water may be able to protect tree growth from detrimental effects is a matter intimitely connected with the amount of previous precipitation. Depending on the rate of surface 


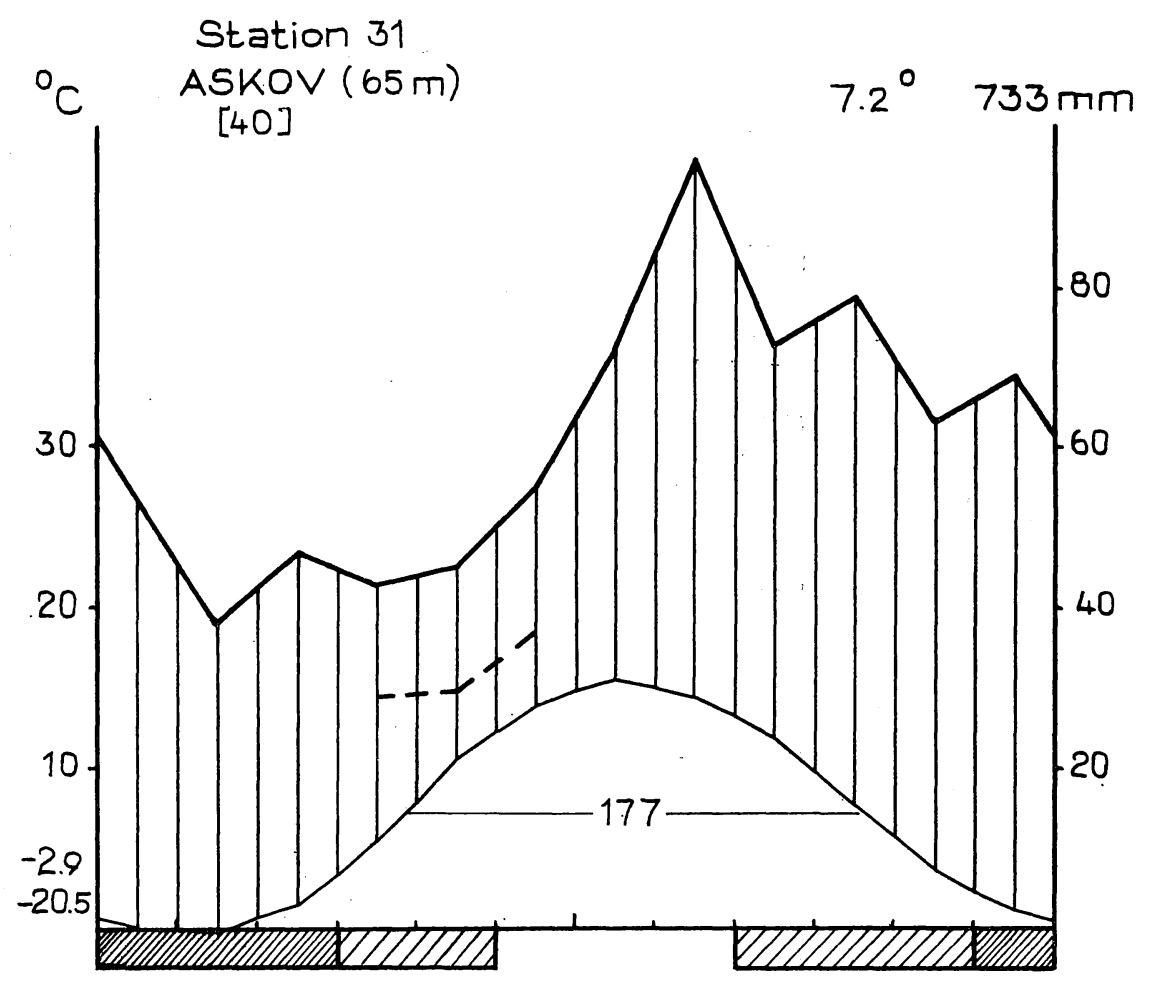

Figure 4. Climate diagram for Askov, Denmark.

runoff and the soil water movements, both autumn and winter rains will here be important and consequently show strong relationships with the growth potential manifested during a drought period. This relationship may then pertain either to one or several months.

Hammershus on the isle of Bornholm is represented by a climate diagram showing a drought of 36 days during the I8o days of growing season (Fig. 6). The drought period mainly occurs in the month of June. During the previous part of the year a very moderate precipitation amounting to about $35 \mathrm{~mm}$ a month is recorded. Minimum rainfall occurs in the period August-December. Whether the more abundant water supply of this period is able to replace entirely or partly the moisture deficit of the drought period is a matter not possible to analyze in this context. However, the question whether the drought period occasionally fails to appear during the climatic changes of the year may be elucidated. Moreover, the length of the drought spell during an extremely rain poor period of the year is of interest. The years of I92I and I923 will here be considered for comparison. The former year shows for Askov 


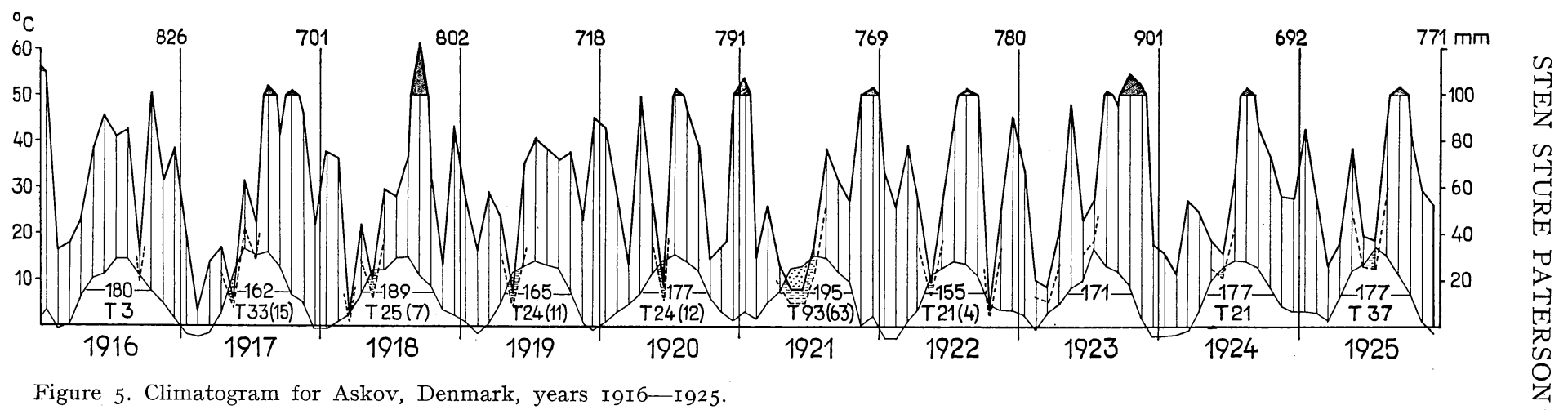




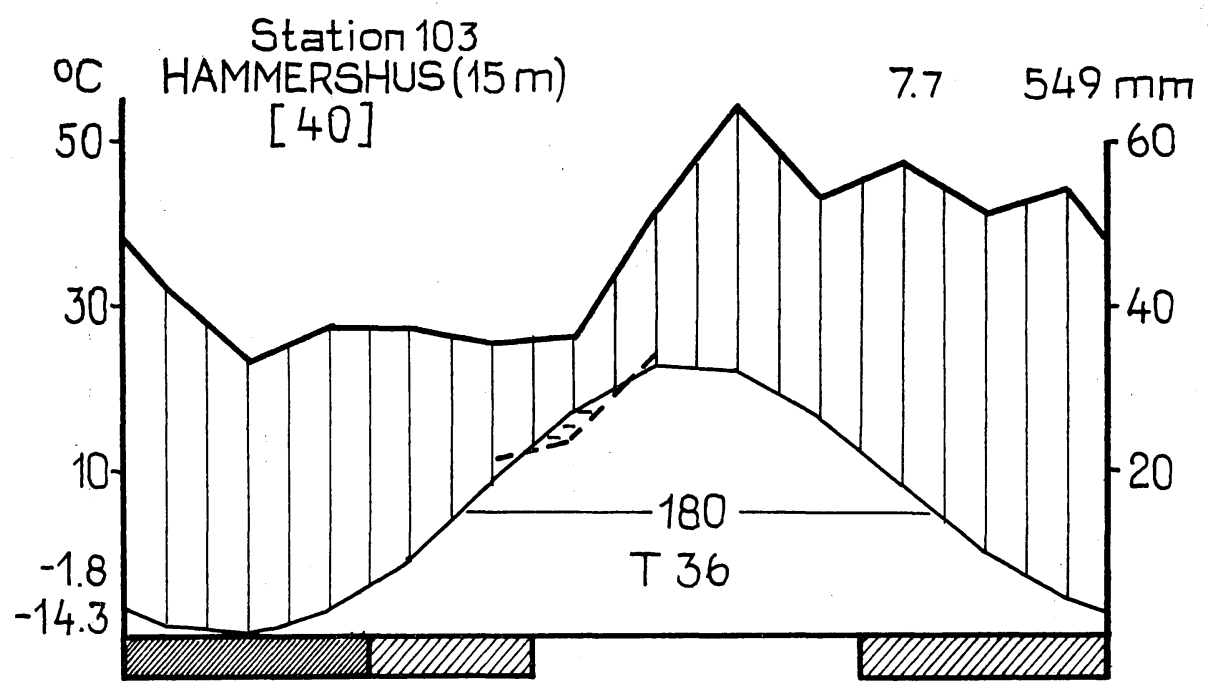

Figure 6. Climate diagram for Hammershus, Denmark.

the longest drought period of the Io-year span whereas the latter year has no such period at all. At Hammershus the year I92I contained a drought period of I35 days in a growing season of I92 days (cf. climatogram, Fig. 7). We must consequently count on such a long reduction of the growth potential that the minimum limit of tree existence is passed unless the supply of capillary moisture and free soil water is sufficient. This, however, does not seem to have been the case in I92I since this year was characterized by a very dry beginning where only the month of January displays a normal value of precipitation after the dry autumn of I920. The growing season I92I must therefore have been entered with an abnormally low soil moisture and low water table.

Unusually heavy precipitation was recorded at Hammershus, as at Askov, (cf. climatogram, Fig. 5,7) in r923. Nevertheless, the drought period is still noticeable although postponed to the month of July and comprising 9 days only. Its effect on tree growth may be judged as minor on account of the humidity surplus of the preceding months. During the 53-year observation period I873-I925 a study of temperature (Climate of Denmark, I933, p. II5) and precipitation (ibid., p. I92 f) shows that no single year displays an entirely humid growing season.

The ombro-thermal situation in Denmark may be summarized as follows: Parts of the country are located within a dry region with a drought period concentrated about the month of June. Other parts are strongly influenced by their closeness to this dry region as manifested by the frequency of years 
${ }^{\circ} \mathrm{C}$ HAMMERSHUS
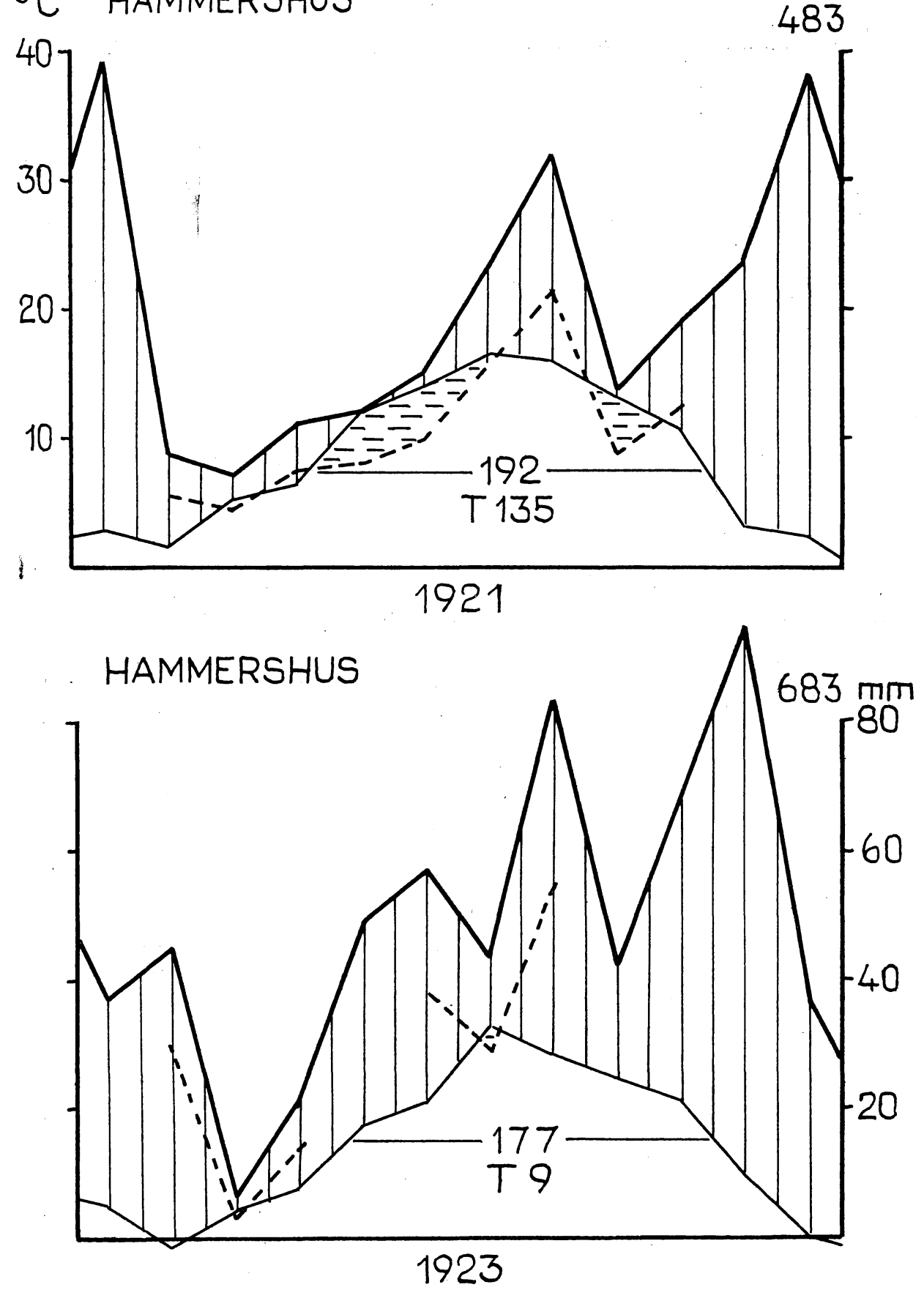

Figure 7. Climatogram for Hammershus, Denmark, years I921 and 1923. 
with drought periods. During the drought spells the growth potential of the trees is dependent on the supply of capillary moisture and free soil water. If this supply of water is deficient, the growth potential is reduced. Precipitation is consequently a periodic minimum factor which means that a certain relation may be expected between the precipitation of one or several months and some indicator of growth potential. This has been shown by E. HolmSGAARD (I955), who found a certain correlation between the variations of the annual ring width and those of precipitation for the month of June and July. Since the annual ring formation mainly occurs during this period, the result of Holmsgaard seems to be reasonable. It would be interesting in this context to check whether length growth, which mainly occurs in May and June, shows a corresponding correlation with the precipitation of these months.

The longest drought periods in Sweden occur on the isles of Gotland and Öland. They are most extreme at Hoburg on the southern point of Gotland, where they comprise $8 \mathrm{I}$ days. This is exactly half of the growing season in the first half of which the drought period occurs. This drought spell may consequently affect particularly the height growth of the trees but also the annual ring development. This situation is typical of the conditions prevailing on the isle of Gotland. The nearby isle of Öland immediately constitutes an improvement in this respect since the drought period here occurs no sooner than three weeks after the beginning of the growing season. Length growth can therefore continue relatively undisturbed. This is the case to a still greater extent within the northern part of the dry region where the drought period usually occurs in the month of July. Potentially, this may affect diameter growth only.

Views discussed above are based on values representing the average conditions of climate. A preliminary evaluation of the variably strong dependence of the growth potential on this medium is possible if the annual changes of the ombro-thermal curves are studied for both the dry and the humid regions. The author has therefore drawn a profile line from the dry region at Kalmar through the humid region over Växjö to Borås. For comparison and for later use in this investigation the locality of Östersund, too, was studied. This place is situated within an area with precipitation maximum in summer (August) - (ST. ST. Paterson, I959, p. II7). The frequency of dry periods within the humid region and the occurence of entirely humid growing seasons within the dry region will be discussed as has been done with regard to Denmark.

The climate diagram for Kalmar (Fig. 8) shows a 2I-day drought period in the month of July. Since the months of May and June furnish a very slight precipitation surplus, water table and soil moisture may be assumed low already at the beginning of the drought period. Especially on sites with 


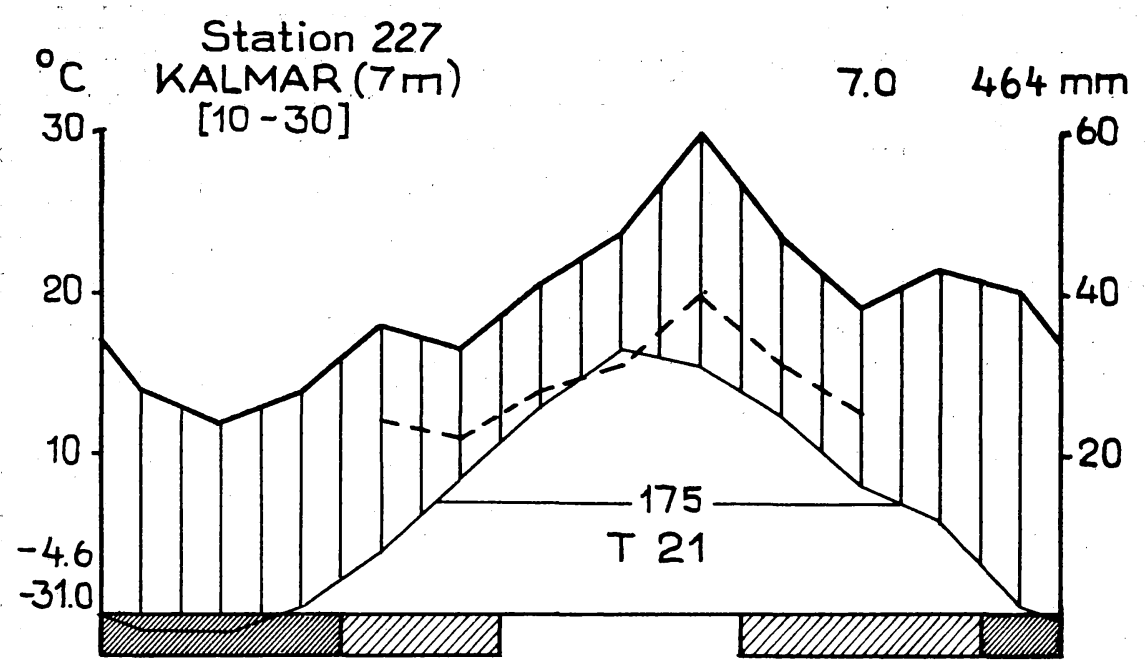

Figure 8. Climate diagram for Kalmar, Sweden.

shallow soil, drought must have a strongly reducing effect on the growth potential and particularly on its diameter growth component. The climatograms of the Io-year period I9I6-I925 (Fig. 9) confirm the validity of the average with respect to the individual years as well. No year lacks drought period. The humidity deficit in its ombro-thermal cover is so great that genuinly arid conditions occur in nine out of ten years. The length of the drought periods varies between 39 days (I922) and I56 days (I92I). The duration of the arid period fluctuates between o (I924) and II7 (I9I7, I92I). Thus, under extreme conditions only 30 days remain of the growing season when growth can proceed under favourable ombro-thermal conditions. The low annual precipitation and its seasonal distribution strongly confirm the assumption that capillary moisture and free soil water can eliminate only to a minor degree the negative effect of drought on plant growth.

The locality of Växjö, situated in the interior of the country shows a hygrometric status of genuinly humid character (climate diagram Fig. II). Although the ombro-thermal curves are well separated, their courses infer a certain risk of drought period also in September. The climatograms of this ro-year period show that this is the case (Fig. Io). Drought periods occurred during seven of the years, five of which in the month of May. Four years display arid spells the duration of which extends over maximum 72 days (I92I) in a drought period of I05 days. In the same year the growing season comprised I86 days. This extreme year thus shows an ombro-thermal situation when the trees are forced to a 72-day dormancy and a period of 33 days with reduced 


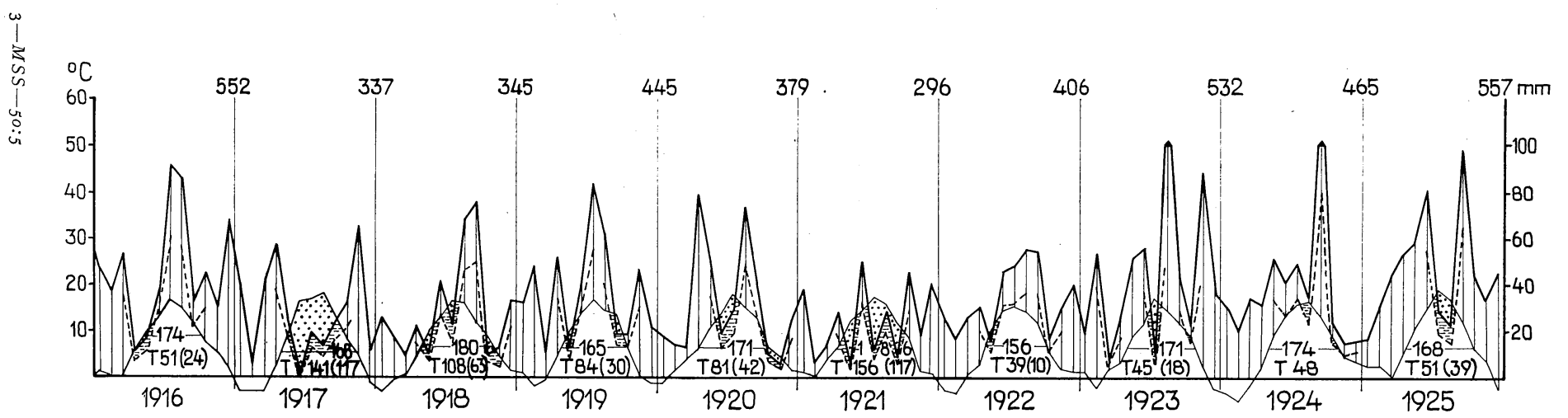

Figure 9. Climatogram for Kalmar, Sweden, years I916-r925.

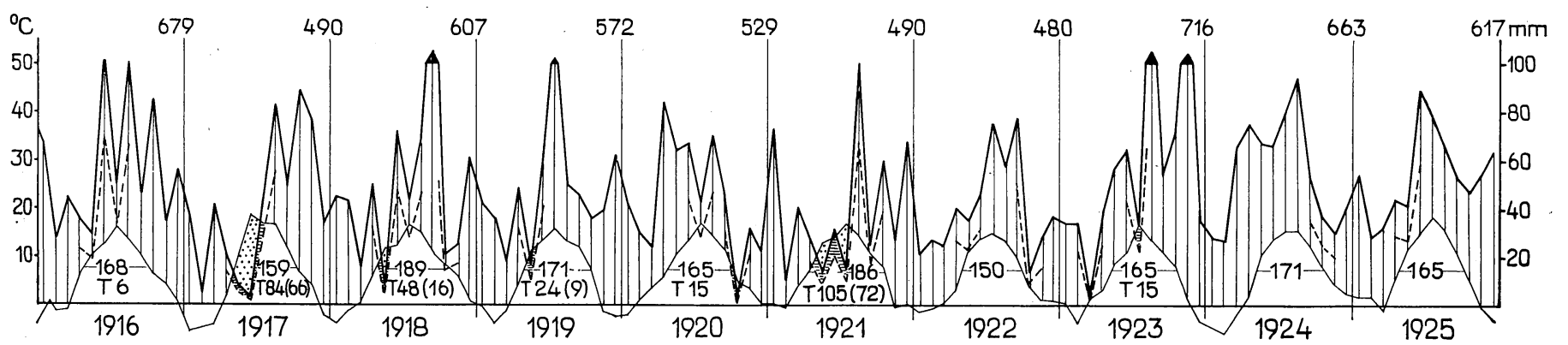

Figure Io. Climatogram for Växjö, Sweden, years I916-I925. 


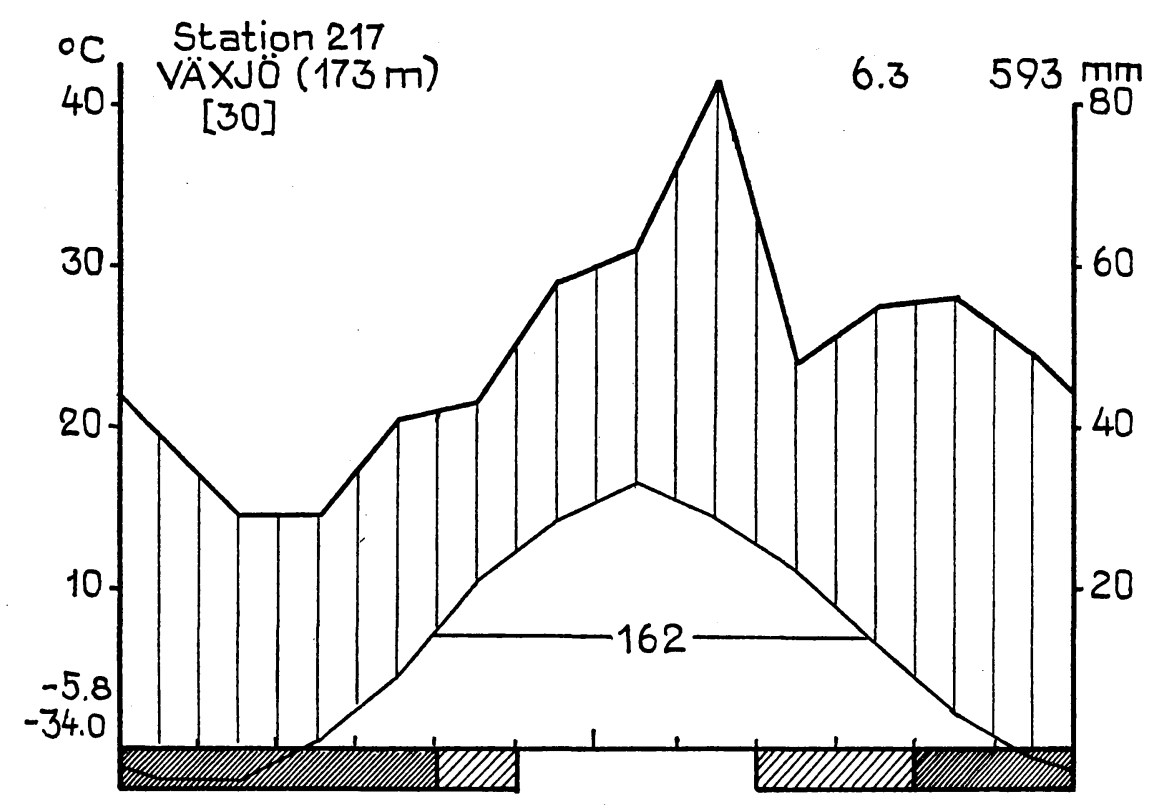

Figure II. Climate diagram for Växjö, Sweden.

functions-all during the beginning of the growing season. Only 8I days remain with conditions favourable for growth. It is again clear that the soil water will be the saving factor in a disastrous situation such as the one reviewed. The extent to which the soil water is able to fill this function can only be elucidated by a special field investigation. The climate diagram Fig. II can now be used only for a statement that winter constitutes a storage of approximately $200 \mathrm{~mm}$ precipitation. It is uncertain how large a portion of this amount remains in the form of soil water at the beginning of the drought period.

The city of Borås is located within the high precipitation area in southern Sweden. The climate diagram (Fig. I2) consequently describes highly humid conditions. The indentation of the rainfall curve in May, however, manifests a certain errancy of precipitation during this period, which is also shown by the climatograms, Fig. I3. During the ro-year span chosen, four years have had drought periods three of which had arid elements, frequently in the month of May. The longest drought period comprising 30 days, I7 of which were arid, occurred in I9I8. In comparison with Kalmar, Hammershus and Askov the humidity of Borås is a considerable fact. The incidence of drought periods is here more rare and of such a short duration that no risks occur with respect to growth potential reducing effects. The high amounts of precipitation recorded during the other parts of the year will be an insurance. 


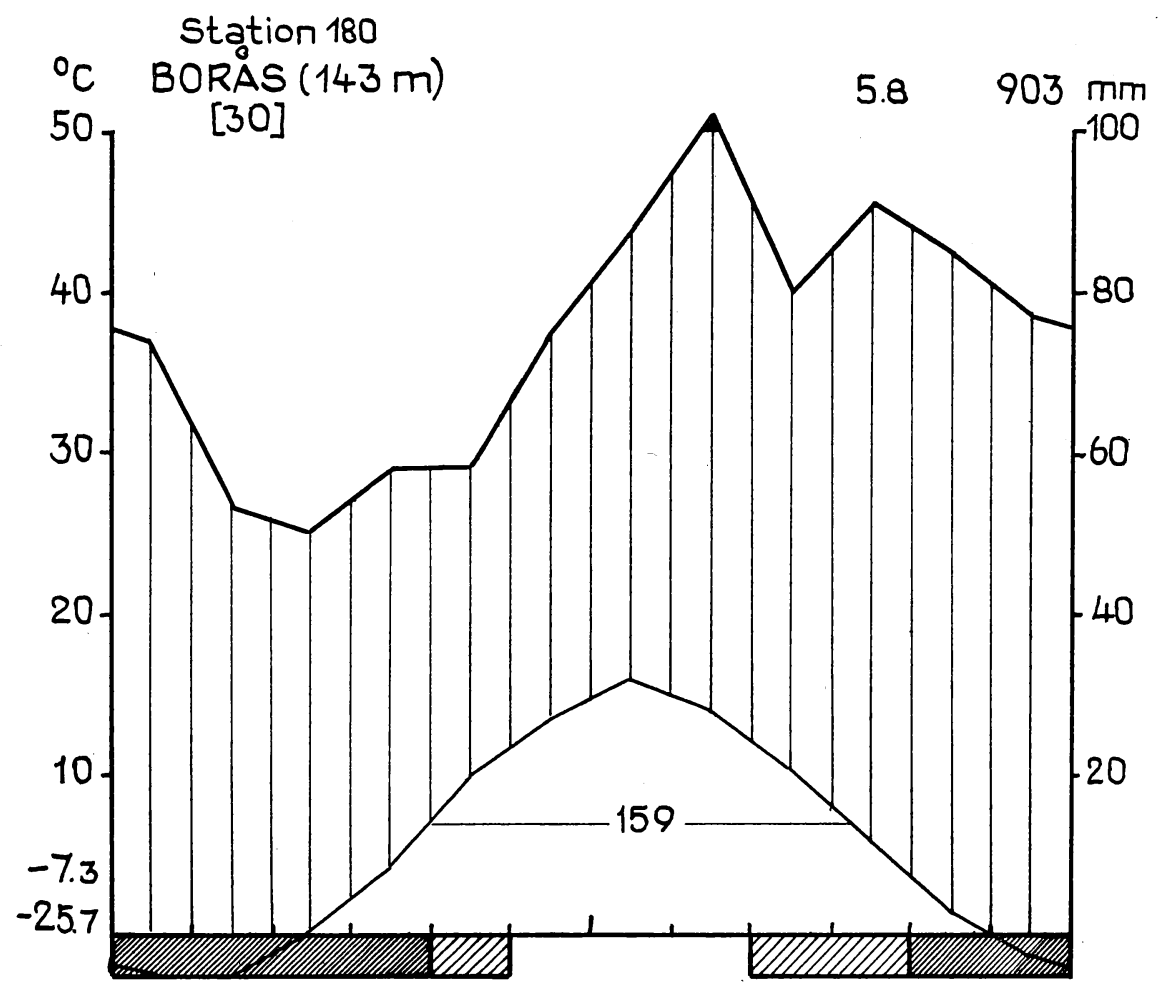

Figure I2. Climate diagram for Borås, Sweden.

The station of Östersund has here been considered for comparison mainly because it has an annual precipitation approximately equalling that of Kalmar, $496 \mathrm{~mm}$ as against $464 \mathrm{~mm}$. Simultaneously, it is located within another bioclimatic region according to the author's division of I959 (p. II7 f).

Precipitation is of a continental type with only one maximum occurring in summer. Previously we have discussed a transition region with two precipitation maxima during the year, one more pronounced in summer and one less pronounced in winter. The climate diagram, Fig. I5, shows that the growing season comprising I20 days is characterized by satisfactorily high humidity. The climatograms, Fig. I4, mainly display the same evidence but they may be read to imply that drought periods have occurred during four of the ten years investigated. The drought periods, however, are consistently weakly developed and they exhibit no arid components during the growing season. The longest drought period occured in I9I7, when it comprised I5 days. Yet, any great influence on tree growth could not be observed since soil contained sufficient amounts of water after the thawing of snow and ice accumulated during the five months' long winter. 


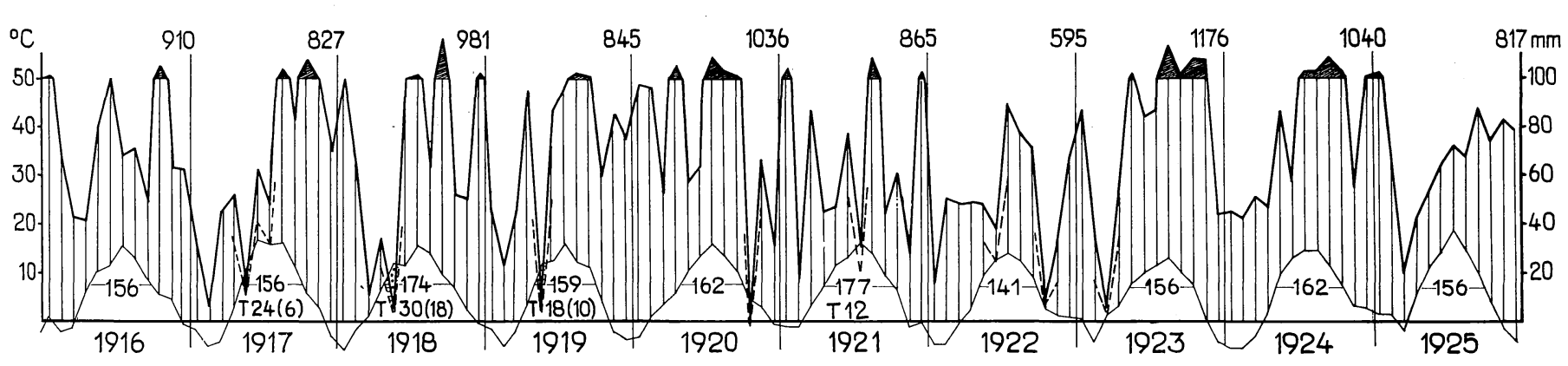

Figure 13. Climatogram for Borås, Sweden, years I916-I925.

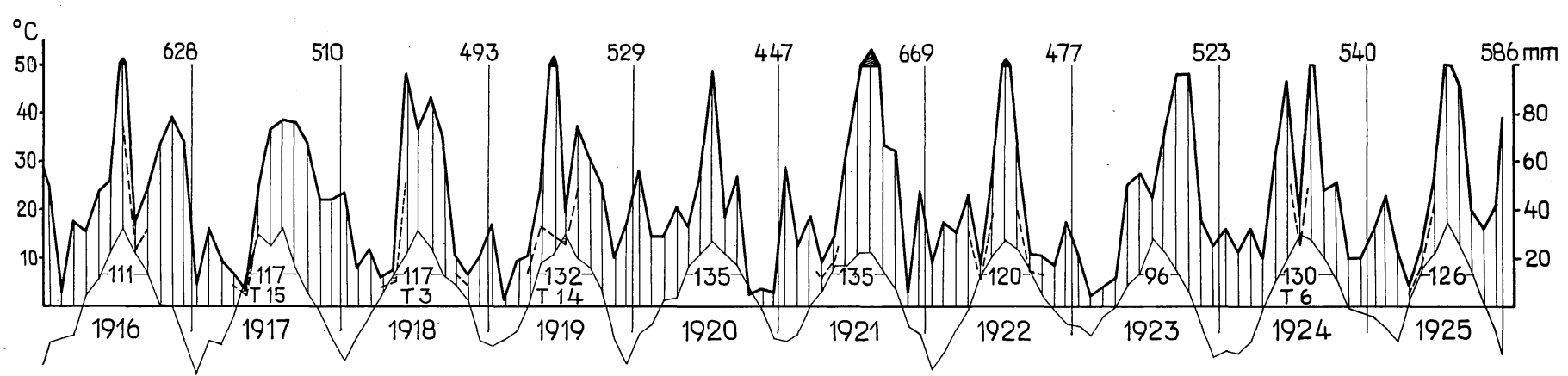

Figure I5. Climatogram for Östersund, Sweden, years r916-I925. 


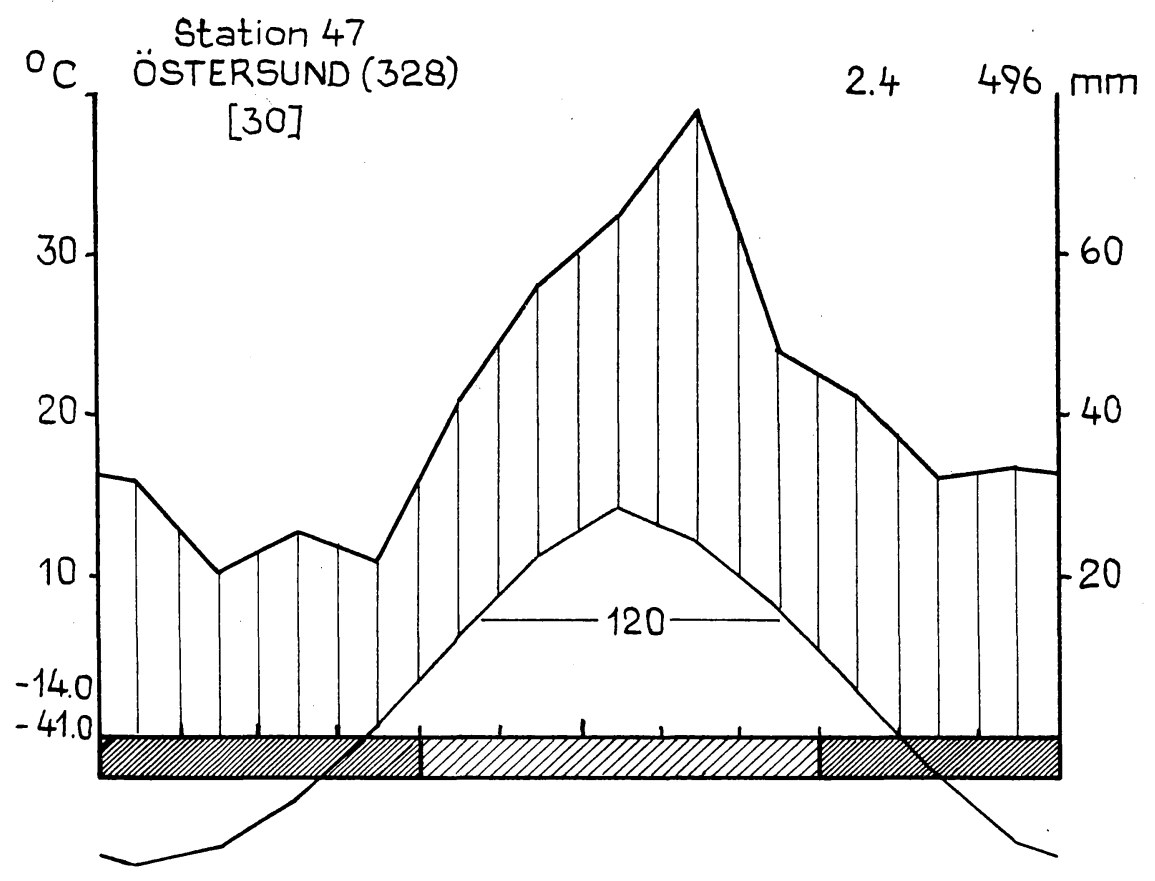

Figure I5. Climate diagram for Östersund, Sweden.

The Östersund area represents an ombro-thermal climate type where water is not a minimum factor from the point of tree growth. Humidity is steadily so high during the growing season that changes in the amount of precipitation cannot be expected to cause corresponding fluctuations in the growth potential or some of its components. This conclusion is also confirmed by the investigations of the relationship between the annual ring variations of spruce within the Östersund latitude and climate carried out by B. Eklund (I957). Contrary to Holmsgaard, Eklund could not find any influence of precipitation on the annual ring variations of Norway spruce which he interpreted as follows: "the humidity available for Norway spruce is sufficient for the assimilation processes during the period when the annual ring formation mainly occurs, even in summers low in precipitation". (B. EkLUND, I957, p. 35, cf. also ibid., I954, p. I20 f.). In the latter paper referred to, a similar result was presented for Scots pine.

A scrutiny of the author's climate diagrams published in "Klimadiagramm Weltatlas" reveals that humid conditions similar to those of Östersund occur in Norden within regions denoted with $D_{s}$ in the author's bioclimatic division, i.e. a boreal climate with precipitation maximum in summer. These areas comprise the Swedish inland north of the province of Dalecarlien and the 
whole of Finland with the exception of a wide coast zone along the Gulf of Bothnia and the Gulf of Finland. Some small isolated areas occur outside this large region in southern Norway and Sweden (cf. map Fig. I8). They are all classified in the perpetually biohumid region characterized by steadily humid conditions during the growing season.

The maritime location of Norway and her rough topography cause interference phenomena expressed by extreme variations in the ombro-thermal conditions even between places geographically very close. Wind-exposed places along the southern and western coast thus receive abundant precipitation all the year round, e.g. the city of Bergen (Fig. I6). The climate diagram shows that no month has less than Ioo $\mathrm{mm}$ precipitation. Nevertheless, the annual changes are so great that drought periods occur during the growing season. In the period r904-I943 twelve years contain drought spells, six of which in the Io-year span I93I-I94I. Some of the drought spells are so extreme that

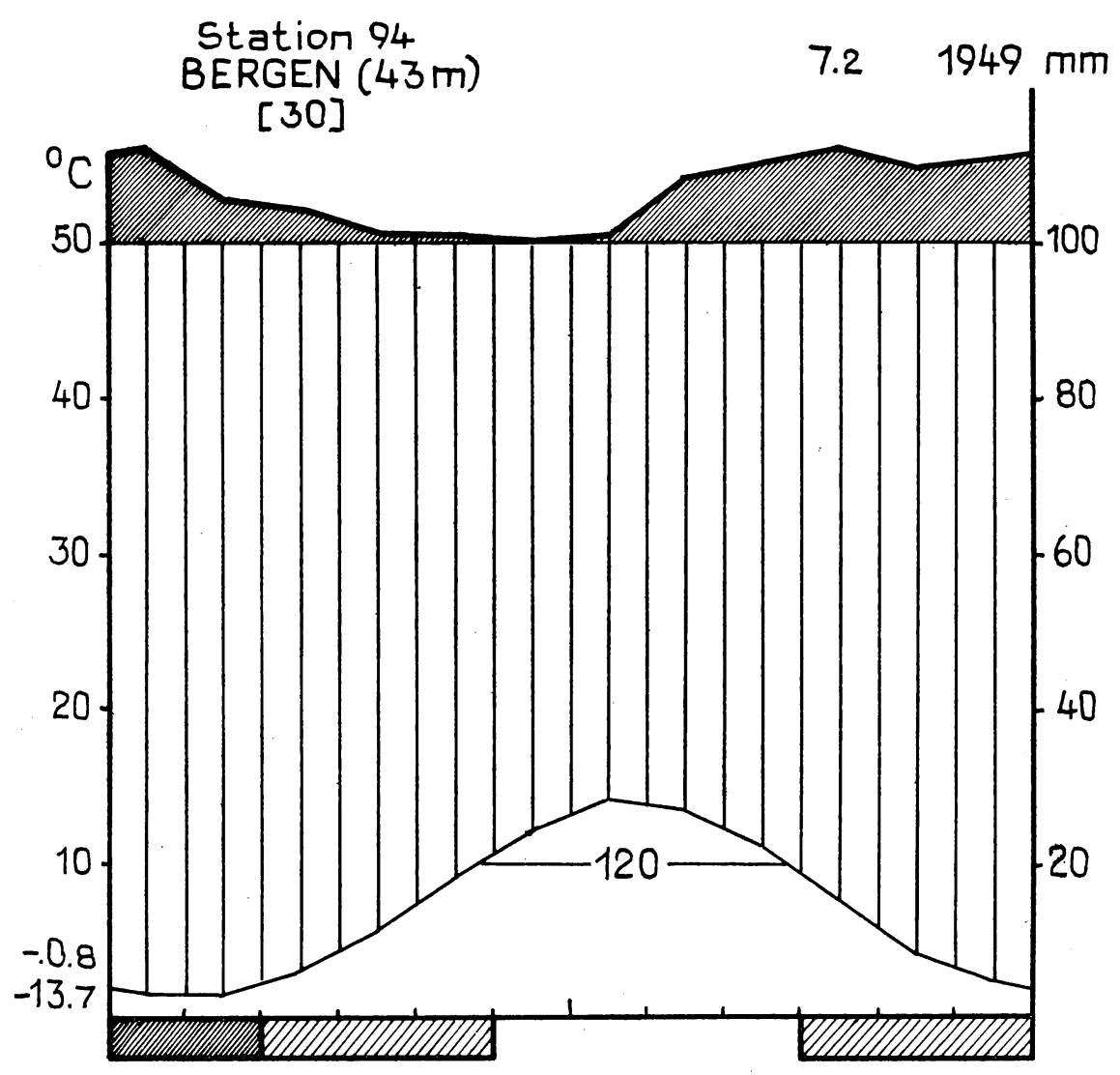

Figure I6. Climate diagram for Bergen, Norway. 
arid conditions occur (e.g. April I9I8, 5 mm; May I936, 9 mm; June I933, $25 \mathrm{~mm}$; July I9Io, $24 \mathrm{~mm}$ ). We may thus state that the southern and western coast of Norway belongs to our intermittent, partially dry region in spite of the high amounts of precipitation.

According to the map, Fig. I8, the perpetually, partially dry region is also found in Norway. However, it does not occur as a continuous area but as small, scattered localities. Generally these places are confined to deep valleys or to the innermost parts of the fjords where rain shadow occurs, in both cases due to deflecting mountaineous areas. An extreme location is represented by the meteorological station at Ulstad, which is outstanding in Norden by having an arid period. Occurring in the months of May and June, the spell comprises the first 36 days of the growing season and is followed by a 33-day drought period (cf. climate diagram, Fig. I7). The part of the growing season with ombro-thermal conditions favourable for tree growth is then only 57 days. The ombro-thermal conditions will here decide whether the existence minimum of forest trees is reached or not. Since the precipitation of autumn, winter and spring is light, the supply of surface water and soil water will be entirely decisive for the creation of a water reserve. Although not covered by meteorological data several places in Norway with locations and ombro-thermal conditions similar to those of Ulstad, must be expected.

As already mentioned, the perpetually biohumid region is also represented in Norway within a limited area in the province of Opland and Buskerud. In our map, Fig. I8, it has been presented as continuous for the sake of simplicity. Actually, it should be divided into small separate areas due to the orographic

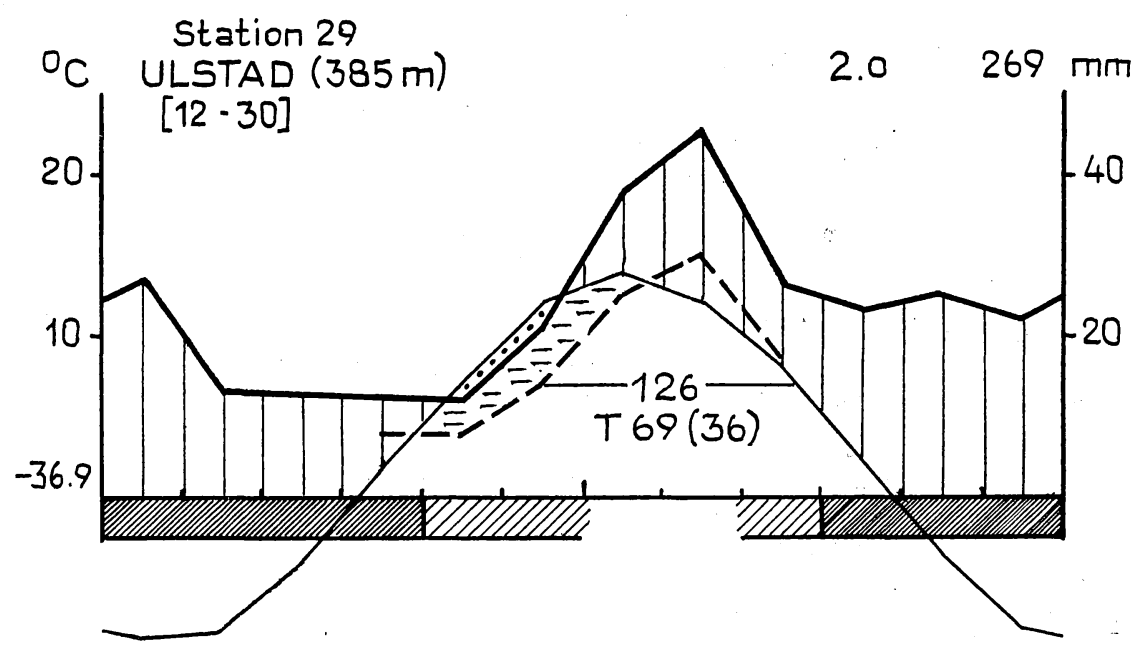

Figure I7. Climate diagram for Ulstad, Norway. 


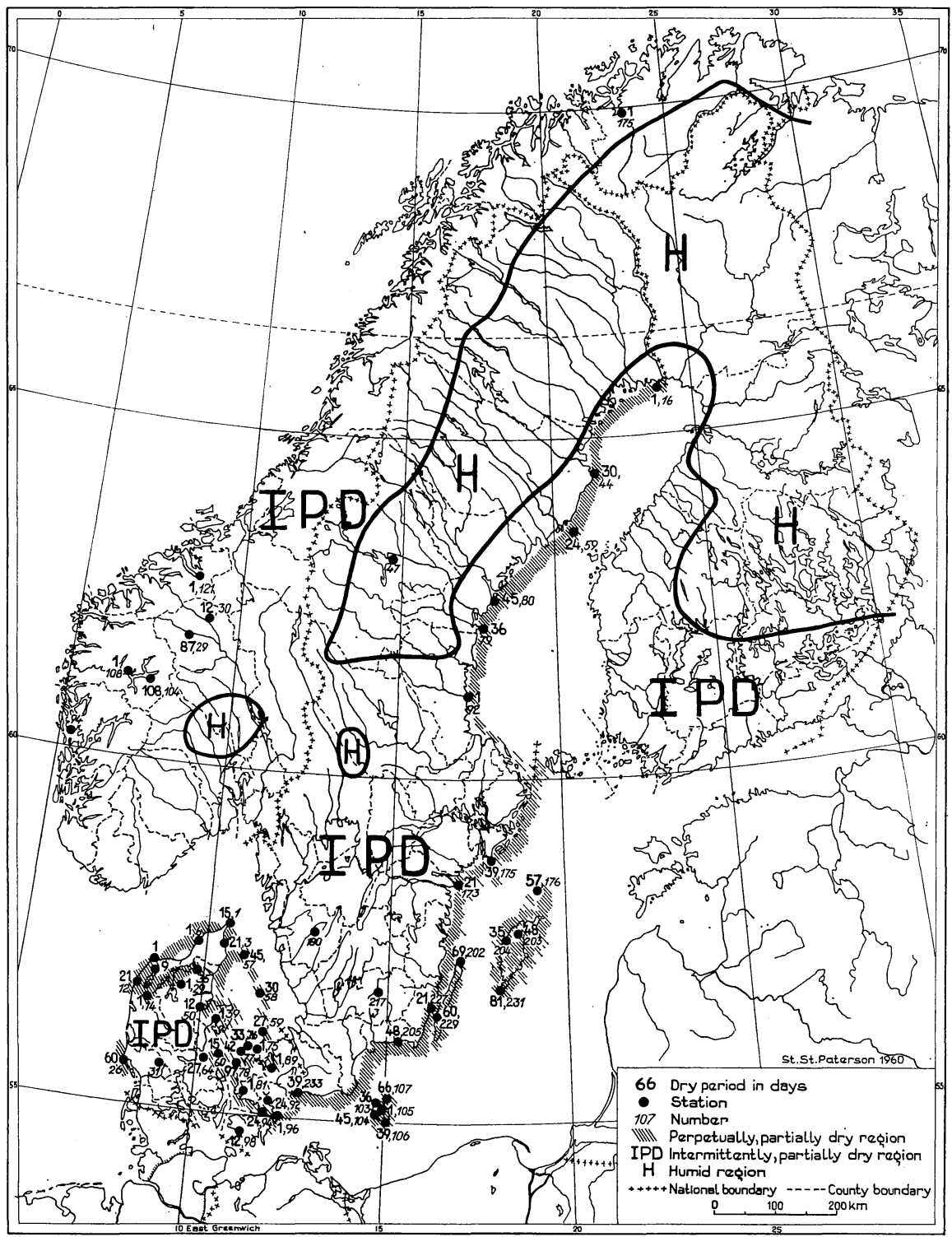

Figure I8. Map of the ombro-hygro-thermal regions of the Nordic countries.

conditions. It is also necessary to count on considerably greater local changes in the ombro-thermal conditions than those occurring within the corresponding region in Sweden.

Regarding ombro-thermal conditions, Finland shows an even transition from a coastal, intermittent, partially dry region to a humid region in the 
interior and northern parts of the country. The hygrothermal conditions of the latter parts correspond to our definition of the perpetually biohumid region. Places with drought period occur in Finland only in the coast regions, e.g. in the westernmost parts of the Aland archipelago and at Tornio in the northernmost part of the Gulf of Bothnia.

\section{The ombro-thermal regions of Norden.}

The investigation of the ombro-thermal conditions in Norden has produced three different regions. This is one region more than those which could initially be separated i.e. the partially dry and the humid regions. The regions are (cf. map, Fig. I8):

The perpetually, partially dry region with annually occurring drought period during the growing season. The drought spells occur during May-August or during parts of this period and may thus affect the genetic cell division, height (length) and diameter growth as well as the storage of nutrients.

The intermittent, partially dry region where years with entirely humid growing season alternate with years with partial drought period. Mostly the drought spell occurs in the latter half of May and in June and its effect on tree vegetation is limited primarily to the height growth assuming that height and diameter growth are independent of each other.

The humid region where drought spells certainly may occur but over such a short period as to preclude any, reducing effect on the growth potential of trees. Observing the edaphic factors, we find a water balance previously assumed as characteristic of the perpetually biohumid region.

It is of interest to compare this regional division with that obtained by O. F. S. Tamm in his study of the humidity of climate in Sweden. This research worker separates six regions of humidity: the sub-arid, the light-humid, the normal humid, the strongly humid, the super-humid and the mountaineous regions (O. S. F. TAMM), I959, p. 30). It is only the sub-arid region that displays an approximate similarity to our perpetually, partially dry region. The lack of similarity otherwise is natural on account of the different principles used for delineation with respect to both method and time (concerning the method used by Tamm, cf. further p. 65). In application the regional division suggested by Tamm, on the basis of his humidity values, gives a description particularly of the runoff conditions, whereas the present author's system is aiming at a definition of the plant physiological effects of precipitation.

\section{Hygro-thermal division}

In the discussion of the regional division presented here, the rôle of the capillary moisture and the free water in the soil as drought 
period compensation is repeatedly questioned. A fairly exhaustive answer requires a surrender of the climatic basis of evaluation used when studying the mutual position of the ombro-thermal curves, and a transition to a corresponding analysis of hygrothermal curves specially designed for the purpose. The hygrothermal curves would then represent the composite influence of climate and edaphic conditions on the supply of water.

The difficulty of transfer to the hygro-thermal method is inherent in the lack of data concerning the moisture status of the soil at various occasions and in various situations. Field investigations are needed concerning the annual changes of the water table (the depth of the water table is generally known within Sweden, e.g. by the investigations of O. Arrhenius, which show that the average depth of the water table varies between $\mathrm{I} 20 \mathrm{~cm}$ and $200 \mathrm{~cm})(\mathrm{O}$. Arrhenius, I956, p. 6) and, too, the soil moisture at various levels. The latter information would be obtained by measuring the resistance, technical equipment for which is available e.g. "Colman fiber glass resistance units". Current and geographically scattered observations of this kind must be considered compulsory for improved knowledge of the yield conditions of the site, particularly in regions with drought period.

The reason for our discussion of water supply and its relation to the forest yield capacity was to find the most feasible expression of the water factor in our yield index. The following conclusions may be drawn as a result of this discussion.

In phyochorological work of summary nature such as the author's global investigations of 1956 and similar work concerning Sweden in 1958, a satisfactory result is obtained with values for the annual precipitation as partial base data. Reservation must be made for extremely humid stations with a water surplus which cannot be utilized for forest growth but rather counteract it. On the basis of analysis of the scatter diagrams with production and $C V P$ as variables, the optimum precipitation in Norden seems to amount to $600 \mathrm{~mm}$.

At phyochorological detail investigations based on the yield conditions of the site, the annual precipitation is an all too vague expression of the hygrical conditions. Continued research in future must here be aimed at procuring values for soil moisture particularly in the root horizon, and the seasonal variations of the water table. Further compilation of the data obtained will produce an expression of the hygro-thermal growing season which is a component more adequate for a yield index than precipitation, particularly for areas with drought period. Due to varying water requirements and ability of adapting within certain limits their growth processes to prevailing water supply, each species must have a defined, 
hygro-thermal growing season of its own. Such a specification must be made with consideration of the time during which the trees function with reduced effect due to drought. It must then also be clarified whether this reduced effect is directly proportional to the simultaneously reduced transpiration. M. G. Stålfelt (I944) presented examples of the latter factor, which show that Norway spruce annually transpires 2 II $\mathrm{mm}$ on a dry site and $378 \mathrm{~mm}$ at high water table.

Data on water supply available for this investigation are composed of precipitation values pertaining to daily, monthly and annual averages. Due to the conditions in the Nordic countries, the annual precipitation probably is no better or worse an expression of humidity than precipitation during selected parts of the year. Lacking a hygro-thermal expression, we therefore choose to use the mean annual precipitation for the standard period I9OI-I930 as being the most easily available for practical purposes.

\section{Material of Investigation}

The basis of our investigation is partly composed of meteorological data and partly of forest yield data. In both cases the values have been computed for other purposes and they are therefore not fit to fill the special requirements of an investigation of this kind. A specification of these requirements at the outset would be impossible, however. Since new avenues are explored part results are obtained, which provide information on the special requirements regarding the basis of investigation.

\section{Forest data}

Yield data from I74 sample plots in Sweden are included in the study. Each plot contains an area of approximately $40 \times 40 \mathrm{~m}$. Material of lesser extent has been obtained from Denmark, Finland and Norway.

It should be stressed that the Swedish yield data represent sites, the yield conditions of which are well utilized by fully closed, natural stands. In other places where open stands have been established for various other reasons, the yield capacity of the site is less well utilized. The following compilation is consequently. based on values for well utilized sites. Due to the subjective choice of sites, however, the sample plots may not always be representative for average climatic conditions, but better than normal edaphic ones, which may result in too high yield data. This seems to be the fact especially in some parts of North Sweden. Nevertheless, our material offers a good basis for a computation of the potential productivity of the entire country.

Since the Swedish material is largest with respect to comprehensiveness and 


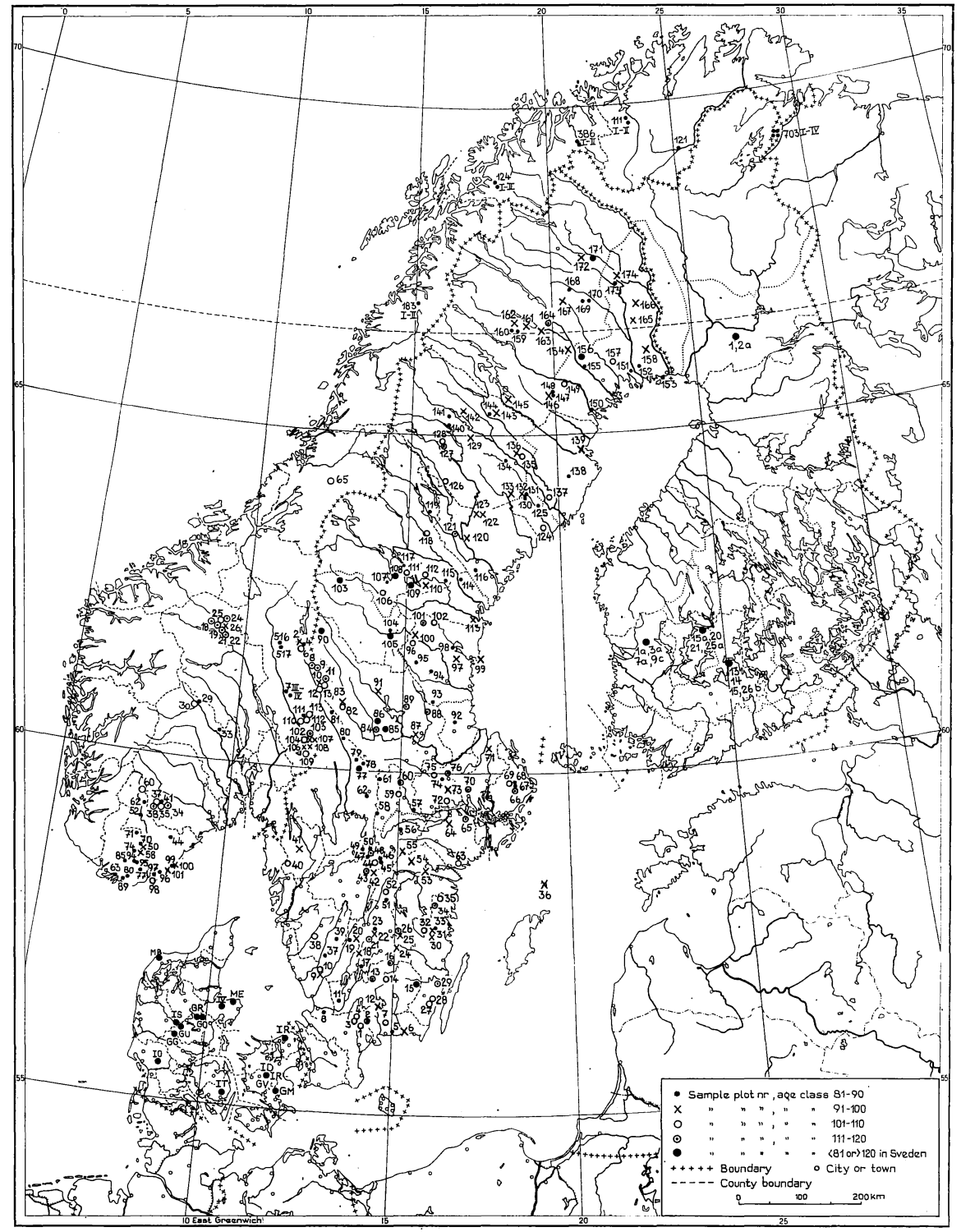

Plate I. The geographical location of the sample plots investigated.

geographical distribution, it has been found suitable to use it exclusively at the further compilation. The sample plot data from our neighbour countries will be used for comparisons at a later stage of the investigation and for a testing of the conclusions drawn from the Swedish data. The comparability 
of the various groups of material will then be discussed. The description of the Swedish yield data has been prepared by professor Charles Carbonnier. The locations of the sample plots are shown in the map, Plate I.

\title{
Yield data of the Swedish localities included in the investigation
}

\author{
By Charles CarbonNier
}

The yield capacity of the site has been characterized by the mean increment per hectare expressed in cu. m. stem wood over bark and above the stump. The mean increment of a site is inter alia dependent on species, method of stand establishment and management as well as length of rotation period. It has appeared that the highest yield of even-aged, pure stands is recorded after natural thinning or a thinning programme barely preceding the natural mortality. Heavy thinning, however, reduces the total yield (PetTerson, I95I and I955, CARBONNIER, I954, I957 and I959). Mean increment in virgin stands, e.g. stands which have not been thinned or otherwise managed, may consequently be considered a good expression of the yield capacity of a site.

The Forest Research Institute of Sweden has recorded a large number of observations made in sample plots scattered over the entire country. Fully closed, naturally established stands of Scots pine and mixed stands with Scots pine in the ages between 8I and I20 years have been utilized for this investigation. Outside these age limits a small number of plots have also been included to represent climatically extreme localities. The composition of the sample plots as regards species and ages is presented in Tab. I.

\section{Allowance for natural mortality}

The plots in virgin stands are of a temporary nature and they have been measured once only. The depletion caused by natural thinning prior to the measurements has consequently not been registered.

An evaluation of the amount of mortality has been based on studies of naturally thinned check plots in permanent thinning experiments. In nothern Sweden, including Norrland and the province of Kopparberg, 28 naturally thinned experimental plots in Scots pine stands and mixed stands with Scots pine have been utilized. In these plots the natural mortality has been recorded in conjunction with the revisions which are carried out with an interval of approximately 5 years. The total yield expressed in per cent of remaining green timber has been dotted over age in a graph at each revision. Although dispersion was considerable, a graphical fitting was attempted for each site class. 
The following series of relative numbers (Tab. 2) were obtained:

Table 2. Total yield in relation to the volume of green timber at various stand ages

\begin{tabular}{|c|c|c|c|c|c|}
\hline \multirow{2}{*}{$\begin{array}{c}\text { Scots pine } \\
\text { site index } \\
\mathrm{h}_{100} \\
\mathrm{~m}\end{array}$} & \multicolumn{5}{|c|}{ Total yield in relation to remaining green timber at age } \\
\hline & 80 & 90 & IOO & I Io & 120 \\
\hline I6 & I.05 & I.09 & I.I3 & I.I 8 & I. 22 \\
\hline I 8 & I.II & I. I6 & 1.20 & I.26 & I.30 \\
\hline 20 & I.I7 & 1.22 & I. 28 & I.34 & I.39 \\
\hline 22 & I.23 & 1.29 & I. 35 & $\mathrm{I} .4 \mathrm{I}$ & I. 48 \\
\hline
\end{tabular}

Site class expression $h_{100}$ indicates the height of the largest tree at an age of Ioo years.

Due to deficient material within the age interval of interest, no corresponding relative numbers could be deducted for site indices above $h_{\mathbf{1 0 0}}=22$ and for South Sweden. The numbers presented above have therefore been used as an allowance basis for the entire country, whereby plots with a site index higher than $h_{100}=22$ are adjusted according to the series for $h_{100}=22$.

\section{The comparability of the yield data}

Since the investigation is based on data from virgin, naturally established stands, it is reasonable to state that the influence of various methods of establishment and various treatments on yield is eliminated.

It would have been desirable to limit the investigation to pure stands of Scots pine or Norway spruce. This, however, was not possible on account of the composition of the material available and the rather limited interval of age considered to be covered by the investigation. The data reported are therefore representing both pure Scots pine stands and mixed stands with Scots pine, where Norway spruce and, although in minor proportions, broadleaved species also occur.

The method of investigation is i.a. based on the fact that variations in the mean increment are minor within a rather wide age interval around the culmination point of the mean increment. Within narrow age groups near the culmination point it is therefore reasonable to compare directly the mean increment values observed and to ascribe the increment variations to the site quality variations, if the stands are otherwise comparable.

At the statistical computations the material has been grouped in the following age classes: 8I-90 years, 9I-IOo years, IOI-IIO years, and IIII20 years. 


\section{The meteorological data}

According to results obtained in the preceding chapter, the following meteorological data are of current interest:

$T_{v}=$ mean temperature of the warmest month

$T_{a}=$ amplitude between the mean temperature values of the warmest and the coldest months

$N=$ the annual precipitation

$G=$ length of growing season in no. days per year when the mean temperature amounts to or exceeds $+7^{\circ} \mathrm{C}$. Moreover, at least three months should display a mean temperature of $+6^{\circ} \mathrm{C}$ or more.

$E=$ ratio for solar radiation according to the author's computations of I956, p. $36 \mathrm{f}$.

On the basis of the data presented above, the computation of the CVP index previously designed by the author is carried out by means of the formula:

$$
C V P=\frac{T_{v} \times N \times G \times E}{T_{a} \times 360 \times 100}
$$

The sole difference here from the formula introduced previously is the expression of the length of the growing season in days instead of months. The reason is that improved accuracy may logically be assumed. Furthermore, the previously used letter $\mathrm{P}$ (precipitation) has been replaced by $\mathrm{N}$ (German: Niederschlag, Sw. nederbörd) to avoid confusion with the $P^{4}$ used in $C V P$.

The meteorological material is gathered from stations for which values concerning mean monthly temperature and mean monthly precipitation are available in meteorological tables. The number of stations with complete data of this kind amounts to Io7 in Denmark, 3I in Finland, I9o in Norway and 139 in Sweden (cf. map, Plate II). In Finland and northern Sweden the number of meteorological stations is very low, which means large areas without observations.

Some condensation of the net of stations has been obtained in Sweden by a utilization of the denser net of precipitation stations. Temperature values have been calculated for 98 stations of this kind by means of a table for normal monthly values of air temperature at sea level and various altitudes. (A. ÅNGSTRÖM, I938) and after adjustments for altitude and potential temperature anomalies. The course of procedure is further described in conjunction with the determination of the sample plot climate values. Distinction between climate stations with complete data of observation and stations with partly computed values has been made in the map by different symbols, Plate II. CVP has been

4 This latter change has been made after that Professor H. Walter, Stuttgard-Hohenheim has drawn attention to this possibilitity of confusion. 
calculated for all the climate stations when sufficient as a basis for the construction of climate isophytes. Table II presents all the climate stations with their $C V P$ indices and data necessary for its computation.

A $C V P$ index was to be computed for each sample plot. Climate data needed for a computation of the $C V P$ indices of the sample plots have only exceptionally been obtained directly from existing meteorological tables since the locations of the sample plots and those of the meteorological stations seldom coincide (cf. the maps, Plate I p. 44 and Plate II p. 49).

The climate data for the sample plots have been computed according to the following method. For each sample plot two of the nearest climate stations are selected so that the line connecting the places is passing through or very close to the sample plot. The location of the sample plot on the line and the values observed at the climate stations are used for a computation of the temperature and precipitation values for the sample plot by interpolation. A generalized statement is also involved since it is assumed that the change of the climate factors between the known station values follows a linear scale, although this is generally not the case. Any great error, however, cannot occur with this method since the differences between the known station values are of moderate magnitude only, for temperature tenths of one centigrade, for precipitation some ten $\mathrm{mm}$. Differences in altitude between the meteorological stations and the sample plot have been compensated for by an adjustment of temperature on the basis of correction factors designed by Wild I88I (cf. A. ÅnGSTRöm, I938, p. 24). The adjustment occasionally concerns both the temperature of the warmest month and the temperature of the coldest month.

Values used here for the vertical temperature gradient were computed by Wild on the basis of Russian data. Since it may be questioned whether they are applicable also to conditions prevailing in Scandinavia, some investigations have been carried out. These investigations were initiated by O. V. JoHANsson in his treatise "Die Temperaturänderungen mit der Höhe an der Erdoberfläche in der Skandinavien" where the material was divided into three groups:

A. Well ventilated stations, relatively small height differences

B. Well ventilated stations, height differences $600 \mathrm{~m}$ or more

C. Valley stations, relatively small height differences (temperature inversion in winter).

The investigation by Johansson, which is interesting not least from a methodical point of view, was repeated by I. BRUUN in I957 on the basis of more recent and complete meteorological data. The material was divided into the same groups. A partial control of the Wild gradients was also carried out by S. RUDBERG, I957. The material was collected from stations located north of 6oth latitude (N) but excluding lighthouse stations (cf. Ångström, I938, 


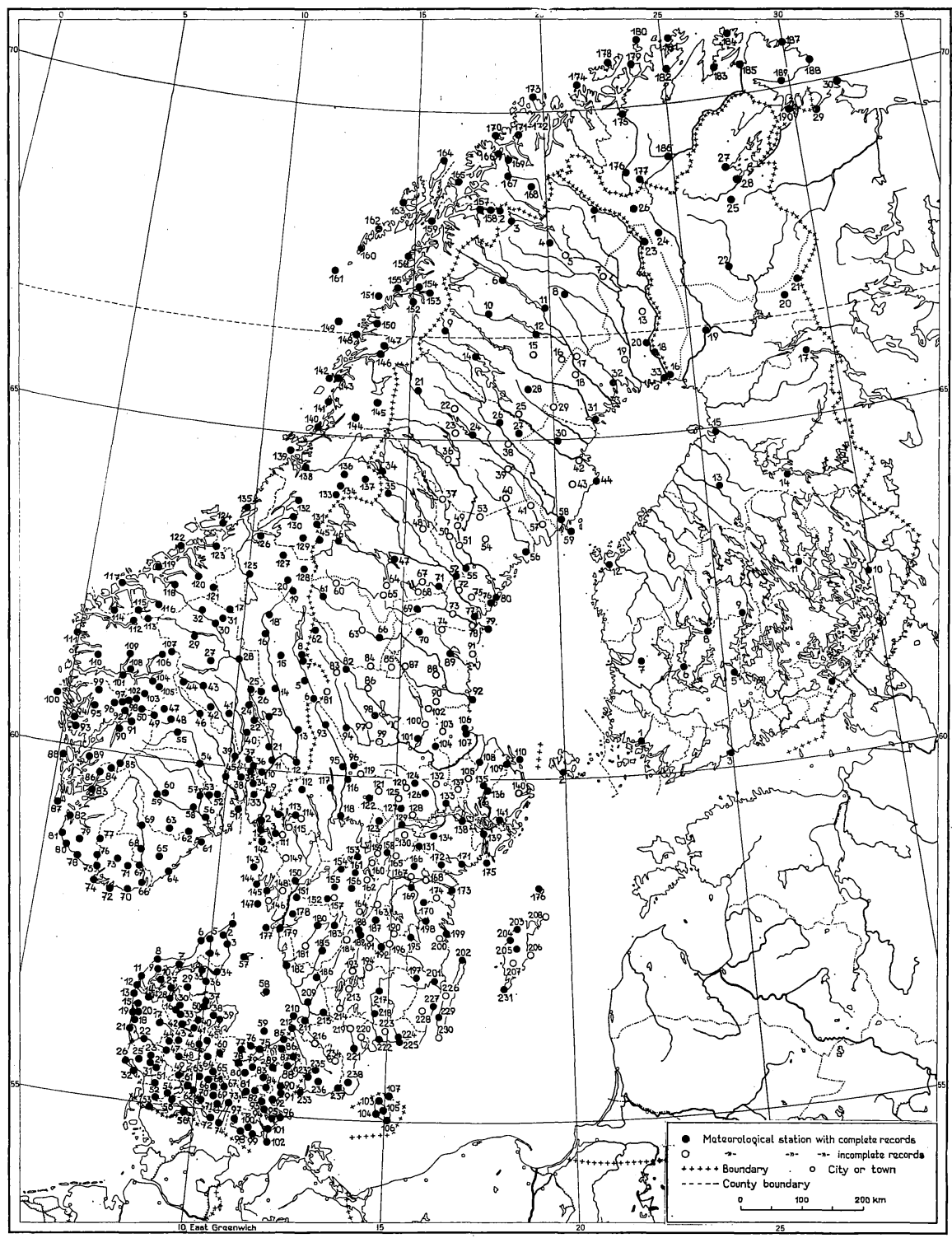

Plate II. The geographical location of the climate stations.

tab. I) and it was restricted to the months of April-September. The values presented by Wild (A. ÂnGström, I938, p. 9) are compared in the following table with the values obtained by BRUUN (I957, p. 45) and RUdBERG (I957, p. 4I). 
Table 3. Temperature decrease by altitude according to Wild, Bruun and Rudberg

\begin{tabular}{|c|c|c|c|c|c|c|c|c|c|c|c|c|c|}
\hline & $\mathrm{J}$ & $\mathrm{F}$ & M & A & M & $\mathrm{J}$ & $\mathrm{J}$ & A & $\mathrm{S}$ & $\mathrm{O}$ & $\mathrm{N}$ & $\mathrm{D}$ & $\begin{array}{l}\text { Year } \\
{ }^{\circ} \mathrm{C} \\
\text { roo } \mathrm{m}\end{array}$ \\
\hline WILD . . . . . . & 0.36 & 0.43 & 0.48 & 0.56 & $0.5^{8}$ & $0.6 \mathrm{I}$ & 0.59 & 0.60 & 0.53 & 0.46 & 0.20 & 0.25 & 0.47 \\
\hline BRUUN A . . . & 0.42 & 0.52 & 0.69 & 0.82 & 0.82 & 0.82 & 0.69 & 0.75 & 0.73 & 0.76 & 0.60 & 0.52 & 0.70 \\
\hline B... & 0.36 & 0.38 & $0.4^{8}$ & $0.6 \mathrm{I}$ & 0.70 & $0.7 \mathrm{I}$ & 0.69 & 0.63 & $0.6 \mathrm{I}$ & 0.55 & 0.47 & 0.37 & 0.55 \\
\hline$A \& B \ldots \ldots$ & $0.3^{8}$ & 0.42 & 0.54 & 0.68 & 0.74 & 0.74 & 0.69 & 0.67 & 0.64 & 0.62 & $0.5 \mathrm{I}$ & 0.42 & 0.60 \\
\hline RUDBERG . . . & & & & 0.37 & $0.4 \mathrm{I}$ & 0.53 & $0.6 \mathrm{I}$ & 0.57 & 0.52 & & & & \\
\hline
\end{tabular}

The comparison shows partly coinciding values for the Wild and Bruun mean values for the groups $\mathrm{A}$ and $\mathrm{B}$. This is particularly the case when one decimal is used, which is applied in this investigation for altitude adjustments. The differences are great between the Rudberg values and the others for the spring months, April and May but very close to the Wild values for the months June-September. Considering the properties of the material, the Bruun A-group seems to be comparable with the Rudberg data, but here the groups display quite a large discrepancy.

Our compilation shows that the temperature adjustment for altitude can be carried out on the basis of the Wild values since no essential deviations are obtained at the computation of the CVP index. Both the Bruun and the Rudberg investigations show that a grouping of the Nordic data according to the principles used by $\mathrm{O}$. V. Johansson is necessary for a computation of more accurate correlation factors. In the present case, however, the requirements of accuracy are such that a compilation of this kind is superfluous.

The procedure of computation when determining the temperature data of a sample plot or a precipitation station is shown in the following example.

Interpolated mean temperature values for the coldest $\left(T_{k}\right)$ and the warmest $\left(T_{v}\right)$ months are to be computed for the precipitation station I6 Puottaure. The station map, Plate II, shows that several possibilities occur when choosing adjacent stations with complete climate data. The stations I4 Vuonatjviken and 20 Övertorneå are located almost on a line with Puottaure in east-west direction. The meteorological tables (A. ÅnGström, I938, p. I8 f) show directly the mean temperature of these stations adjusted to sea level $(m k)$. An adjustment must be made for the difference in latitude $(\varphi)$ between the stations as well as for the altitude $(h)$ of the precipitation station. Both the latter adjustments are carried out by means of existing standard tables (cf. ÅGSTRÖM, I938, p. 24, tables Io and II). Our computations have been summarized in the following table.

The final values thus obtained for the stations I4 and 20 are the temperature values applicable to I6 Puottaure. Exactly equal values should have been obtained for corresponding temperature data but differences have occurred. 


\begin{tabular}{|c|c|c|c|c|}
\hline \multirow{2}{*}{$\begin{array}{c}\text { Station } \\
\text { No. }\end{array}$} & \multicolumn{2}{|c|}{ I 4} & \multicolumn{2}{|c|}{20} \\
\hline & $T_{k}$ & $T_{v}$ & $T_{k}$ & $T_{v}$ \\
\hline \multirow{4}{*}{$\begin{array}{l}m k \ldots \ldots \\
\varphi \ldots \ldots \ldots \\
h \ldots \ldots \ldots\end{array}$} & - II.40 & $\mathrm{I} 4.5 \mathrm{I}$ & - I I. 37 & I6.06 \\
\hline & o.IO & 0.02 & O.I 5 & 0.03 \\
\hline & - I.I3 & 一 I.86 & - I.I3 & $-\mathrm{I} .86$ \\
\hline & - 12.43 & I 2.67 & $-\mathrm{I} 2.35$ & I 4.23 \\
\hline
\end{tabular}

The $T_{k}$ values diverge with only $0.08^{\circ} \mathrm{C}$ which is a very slight discrepancy, particularly since the temperature values included in the CVP index are used only with one decimal. The agreement is less good between the $T_{v}$ values, the difference amounting to $\mathrm{I} .56^{\circ} \mathrm{C}$. The cause of this discrepancy is to be found in factors other than geographical latitude and altitude. These factors are joined in the term anomaly. The Angström anomaly map for the month of July (A. ANGSTRöm, I938, plate IV) shows that our station line is passing from an area in west with negative anomaly (- I. $5^{\circ} \mathrm{C}$ ) to the boundary areas adjacent to Finland in the east with a positive anomaly $\left(+0.06^{\circ} \mathrm{C}\right)$. The sum of the values presented represents the difference of the temperature values of the stations. We now adjust the $T_{v}$-values previously computed and obtain.

$\mathrm{I} 2.67^{\circ}+\mathrm{I} .5^{\circ}=\mathrm{I} 4 . \mathrm{I} 7^{\circ}$ and $\mathrm{I} 4.23^{\circ}-0.06^{\circ}=\mathrm{I} 4 . \mathrm{I} 7^{\circ}$, respectively. Thus complete agreement is obtained.

Assuming that the change of anomaly occurs linearly, we can now compute the temperature anomaly for the month of July at Puottaure. This place is located at a point dividing the line from Vuonatjviken to Övertorneå in the ratio 25: 3I. The difference in anomaly between the stations I4 and 20 is divided accordingly i.e. the temperature anomaly of Vuonatjviken (origin) - I. $5^{\circ} \mathrm{C}$ should be raised with $+0.69^{\circ} \mathrm{C}$ to give the anomaly for Puottaure, i.e. $-0.8 \mathrm{I}^{\circ} \mathrm{C}$. The actual July temperature thus is $\mathrm{I} 4 . \mathrm{I} 7^{\circ} \mathrm{C}-0.8 \mathrm{I}^{\circ} \mathrm{C}=$ $13.36^{\circ} \mathrm{C}$. The same value is obtained if the computations are based on the Övertorneå station.

The same procedure is used when the $T_{k}$-value is adjusted for the anomaly. The value of $T_{k}$ now calculated is subject to a certain criticism. The Ångström map of anomalies (ibid., plate I) shows that our station line is crossing over an area with negative anomaly exceeding those reported for the stations used (cf. Fig. I9). This means that the change of anomaly is non-linear, which contradicts the assumption needed for our computations. We must therefore try to find two other climate stations with a more suitable direction of the connecting line. This seems to be the case of the stations I2 Jokkmokk and 32 Högsön (cf. Fig. I9). They provide the following values: 


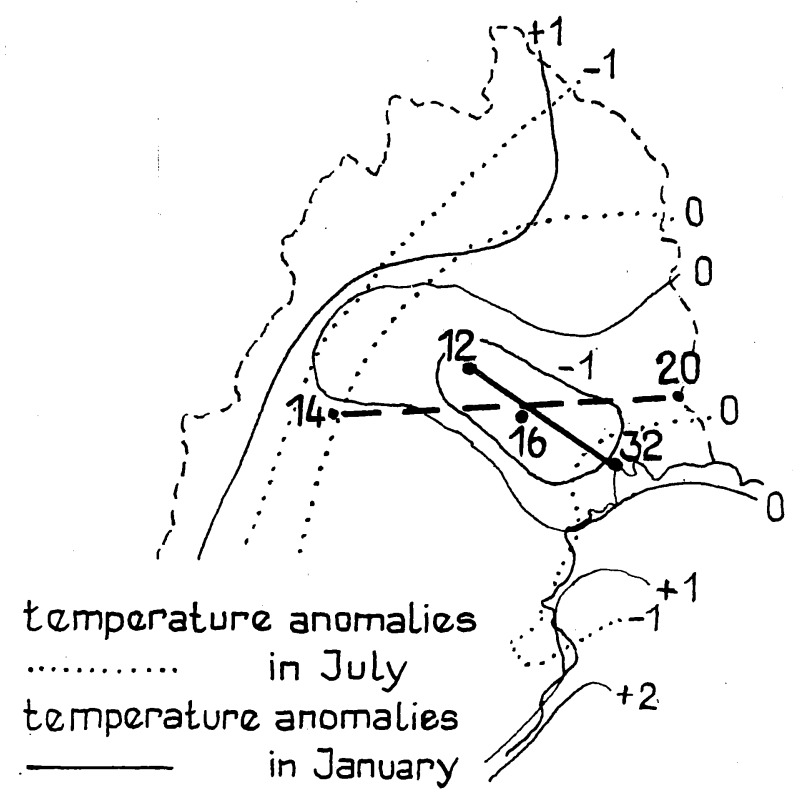

Figure r9. The location of the station lines in relation to anomalies.

\begin{tabular}{|c|c|c|c|c|}
\hline \multirow{2}{*}{$\begin{array}{c}\text { Station } \\
\text { No. }\end{array}$} & \multicolumn{2}{|c|}{ I 2} & \multicolumn{2}{|c|}{$3^{2}$} \\
\hline & $T k$ & $T_{v}$ & $T_{k}$ & $T_{v}$ \\
\hline$m k$. & - I3.OI & I6.22 & - II.36 & I 5.88 \\
\hline$\varphi \ldots \ldots$ & 0.30 & 0.07 & -0.50 & - o.10 \\
\hline$h \ldots \ldots$ & 一 I.I3 & 一 I.86 & - I.I3 & 一 1.86 \\
\hline \multirow[t]{2}{*}{ Anomaly. } & $2.2 \mathrm{I}$ & -0.32 & I.06 & 0.12 \\
\hline & $-11.63^{5}$ & $\mathrm{I} 4 . \mathrm{II}^{5}$ & $-\mathrm{II.93^{5 }}$ & $14.04^{5}$ \\
\hline
\end{tabular}

Corresponding temperature values are used for a computation of the mean value to which the temperature anomaly of the month calculated according to the method previously discussed, is added. We then obtain the following temperature values for Puottaure:

\begin{tabular}{|c|c|c|}
\hline \multirow{3}{*}{ Anomaly... } & $T_{k}$ & $T_{v}$ \\
\hline & $\begin{array}{r}\text { - II. } 78 \\
-\quad 1.83\end{array}$ & $\begin{array}{r}\text { I } 4.07 \\
\text { O.I } 7\end{array}$ \\
\hline & $-\mathrm{I} 3.6 \mathrm{I}$ & $\mathrm{I}_{4} .24$ \\
\hline
\end{tabular}

5 The difference from the other station is caused by the anomaly admitting a computation of mean temperature with an accuracy of about $\pm 0.2^{\circ} \mathrm{C}$ (A. ÅNGSTRöM, I938, p. 69). 
The values for $T_{v}$ and $T_{k}$ now obtained must be considered to reflect the influence of temperature anomaly better than the temperature values derived in the first attempt.

The method developed above for the computation of temperature has consistently been used in the following for the procurement of data needed for precipitation stations and for sample plots. Data thus obtained are reported in a special foot note in table II.

The influence of topography, exposure, altitude and gradient on the amount of precipitation is known as to its general features. The magnitude of this influence is determined for certain small localities of investigation. The results show that precipitation and light conditions vary widely within small areas (P. E. VÉzINA, I96o, p. I33). It is consequently impossible to generalize with the observations available and to arrive at correction factors applicable within other areas. We must therefore ignore the local variations of precipitation. The entailing disadvantages are not so serious in Denmark and in south and middle Sweden since the net of precipitation stations is relatively dense. In northern Sweden and in large areas of Norway and Finland where the stations are sparse and located mainly in valleys, however, the disadvantages are great. This means that observations are largely deficient in the highland areas which are important for forestry. It must here be pointed out that considerable differences may occur particularly between the precipitation climate of valleys and that of the highland, a difference the magnitude of which we have no means of evaluating.

The method used when the length of the growing season is computed has been described previously. Exceptions, however, have been made for practical reasons for climate stations and sample plots with interpolated temperature values. In these cases a determination of the length of the growing season would involve a computation of at least four temperature values, two for spring and two for autumn according to the procedure now described. This would be a very tedious work without a result corresponding in accuracy to the efforts since the errancy of the local climate remains. Thus the considerably simplified procedure with interpolation between the growing season of the known stations was applied to obtain the growing season of the locality concerned. Here, too, it is assumed that the change in the length of growing season between the climate stations is linear. Moreover, the interpolation must be preceded by an adjustment for altitude, which is influential in this context.

\section{Decrease in length of growing season at rising altitude}

Investigating the relationships between the length of the growing season and latitude as well as altitude, O. LANGLET (I936, p. 344 f) found that the growing 
season decreases by approximately 5 days per roo $\mathrm{m}$ increase in altitude. The computations are based on the assumption of a linear regression, and local conditions of climate were not considered, nor regional differences in air humidity, carbodioxide content of air, cloudiness and air pollution. The existence of such differences has been proved by e.g. Czech investigations (cf. M. NoseK, I958, p. 482). The weaknesses are discussed by Langlet who furthermore stressed that the method provides no expression of either change in height at various altitudes or a varying influence of northward transfer at various altitudes. It would be of interest to study the results of an arrangement and compilation of the Langlet material by altitude. The most important matter in this context is the influence of height changes at various altitudes and it will therefore be studied closer.

The reduction of the length of the growing season at rising altitude should be studied under conditions where altitude alone is the variable and factors such as continentality, maritimity, latitude, mass elevation and other influencing factors mentioned in this context are constant. This is most feasibly arranged in small areas with great altitudinal differences, where meteorological stations are established at nearly vertical distances from each other. Conditions of this kind are found in Norway.

Initially we shall select three comparably well situated station Oslo I, Oslo (Blindern) and Tryvasshögda. The distance between these stations is less than Io $\mathrm{km}$, which means that the meteorological differences between the stations are mainly to be considered caused by differences in altitude. The station Oslo $I$ is located in the park of the observatory at an altitude of $22 \mathrm{~m}$, whereas the Oslo-Blindern altitude is $94 \mathrm{~m}$. The latter station is considered by I. BRUUN, state meteorologist, (I957, p. 23) to be representative of the temperature conditions prevailing in the interior Oslo fjord at this altitude. The distance between these two places of observation is slightly more than three kilometers in north-south direction. Within this distance the growing season decreases from I62 days to I53 days, which means a reduction of one day per $8 \mathrm{~m}$ rise. The distance between Oslo-Blindern and Tryvasshöjda is approximately $7 \mathrm{~km}$ and the altitudinal difference is $4 \mathrm{I} 8 \mathrm{~m}$. Here the reduction of the length of the growing season amounts to 24 days, i.e. a reduction of one day per I7 $\mathrm{m}$ increase in altitude. Tryvasshögda is considered (ibid. p. 28) to provide representative temperature values for the area of Nordmarka at this level. Due to the topographic conditions great local variations may occur concerning the sub-zero temperature values. Their influence on the computation of the length of the growing season, however, must be considered minor only.

The station Holmenseter is located between Oslo-Blindern and Tryvasshögda. Altitude is here $294 \mathrm{~m}$ and the growing season thus decreases at a rate 
of one day per $15 \mathrm{~m}$ rise, but at a rate of one day per $20 \mathrm{~m}$ rise from Holmenseter to Tryvasshögda.

Observations concerning the relationship between the length of the growing season in the Oslo area and altitude are now supplemented with the stations listed in Table 4.

Tab. 4. Decrease in the length of growing season at increasing altitude for various stations

\begin{tabular}{|c|c|c|c|c|c|}
\hline \multirow{2}{*}{ Stations of comparison } & Altitude & $\begin{array}{l}\text { Difference } \\
\text { in altitude }\end{array}$ & $\begin{array}{l}\text { Growing } \\
\text { season }\end{array}$ & $\begin{array}{l}\text { Differ- } \\
\text { ence }\end{array}$ & \multirow[t]{2}{*}{$\mathrm{m} /$ day } \\
\hline & \multicolumn{2}{|c|}{ meter } & \multicolumn{2}{|c|}{ days } & \\
\hline Kongsberg II-Knutshytta. & I $55-7$ I 7 & 562 & I 43 - I I 4 & 29 & I9 \\
\hline Hamar-Vang på Hedmark. & I $39-2$ I9 & 80 & I $4 \mathrm{I}-\mathrm{I} 38$ & 3 & 27 \\
\hline Flisa-Åsnes . . . . . . . . . & $183-234$ & $5^{\mathrm{I}}$ & I37-133 & 4 & I3 \\
\hline Dovre-Dombås........... & $570-643$ & 73 & $105-\mathrm{IO} 2$ & 3 & 24 \\
\hline Engerdal I och II....... & $538-479$ & 59 & $100-108$ & 8 & 7 \\
\hline Dalen i Telemark I och II. & 102- 77 & 25 & $\mathrm{I}_{5} \mathrm{I}-\mathrm{I} 47$ & 4 & -6 \\
\hline Mandal I och II......... & $6-138$ & 132 & $I 73-I 68$ & 5 & 26 \\
\hline Ullensvang I och II . & $55-30$ & 25 & $165-\mathrm{r} 68$ & 3 & 8 \\
\hline Bergen I och II ........ & $20-43$ & 23 & $\mathrm{I}_{74}-\mathrm{I} 7 \mathrm{I}$ & 3 & 8 \\
\hline Bergen II-Rundemannen. . & $43-560$ & 517 & I $7 \mathrm{I}-\mathrm{IO} 8$ & 63 & 8 \\
\hline Bergen I-Rundemannen .. & $20-560$ & 540 & $174-108$ & 66 & 8 \\
\hline Molde I och II......... & $18-50$ & 32 & I $54-I_{50}$ & 4 & 8 \\
\hline Bodö III och IV... & $33-10$ & 23 & $122-119$ & 3 & 8 \\
\hline Tromsö I och II ... & $45-\mathrm{IO} 2$ & 57 & $98-9 I$ & 7 & 8 \\
\hline
\end{tabular}

Some of the stations listed in Table 4 are less representative from a meteorological point of view.

An increase of $27 \mathrm{~m}$ in altitude is required at Hamar-Vang in the Hedmark area to reduce the growing season by one day. This is nearly twice the value $(\mathrm{I} 5 \mathrm{~m}$ ) recorded in the Oslo area at the level of I0o-200 $\mathrm{m}$. The station description in "Lufttemperaturen i Norge" states that the lake of Mjösa has a distinctly smoothing effect on the temperature conditions of the surrounding lowland. This explains with great probability the essentially slower decrease of growing season with increasing altitude stated for Hamar-Vang.

At Engerdal I and II an increase of altitude by $7 \mathrm{~m}$ reduces the growing season by one day. This is considerably less than the expected difference in altitude for one day's increase or decrease of the growing season and seems to indicate locally pronounced climate conditions. Circumstances associated with the natural situation also indicate this to be the case. Engerdal I is located approximately $70 \mathrm{~m}$ above the valley bottom on a steep slope with ENE exposure. Engerdal II is located on the opposite side of the valley with WSW exposure. These locations cause the stations to provide data indicating a temperature climate deviating from the normal. Engerdal I displays lower temperature 
values than normal for this location on account of an abnormally oblique insolation angle whereas entirely different conditions occur at Engerdal II due to straight angle insolation. Here (Engerdal II) temperature is higher than normal with a positive anomaly particularly distinct in spring and autumn.

The valley in Telemark I and II constitutes an example of temperature inversion which develops under certain conditions. Here it is caused by the deep valley and associated special air movements. In winter the prevailing winds follow the valley downward. A certain foehn-effect arises through this simultaneously as a stagnation of the airmass with accompanying radiation cooling is prevented (I. BRUUN, I957, p. 9). In summer, air in this valley becomes locally heated, which creates a circulation characterized by warm rising air which is replaced by colder air entering along the valley bottom. This explains why a more favourable year-round temperature climate occurs at a higher altitude than at the bottom.

Mandàl I and II show a slowly decreasing growing season at increasing altitude, a $26 \mathrm{~m}$ rise gives a reduction of one day as against $8 \mathrm{~m}$ per day in the Oslo area. Bruun $($ I957, 9.20) stated that Mandal II is located $2.5 \mathrm{~km}$ north of the community of Mandal with the station Mandal I. The temperature data from Mandal II are considered representative for a large inland area, not so, however, for Mandal and the area south, east and west of this community. The latter area is affected by frosty mist from Mandals-elva (river) in winter and by coast fog in summer.

Bergen I and II and Rundèmannen show equal change of altitude for one day reduction of the growing season, viz. $8 \mathrm{~m}$, a value corresponding to about II $\mathrm{m}$ in the Oslo area. The value indicates faster changes in temperature climate than normal i.e. we pass from one local climate to another. This is also confirmed by meteorological authorities, who stress that Bergen II is representative only of the immediate surroundings of the harbour in calm winter weather (I. BRUUn, I957, p. 7). Comparison may here be made with the observations of W. A. Fairbairn in Scotland. He found that the growing season is decreasing by one day for each $8 \mathrm{~m}$ increase in altitude within the zone below $500 \mathrm{~m}$. For the zone $500-750 \mathrm{~m}$ he obtained I9 $\mathrm{m}$ per day reduction, but he considered the latter values less accurate (W. A. FaIRbairn, I955, p. I6). The resemblance to the Bergen conditions is striking.

No climatic discrepancies of this kind occur between the stations of comparison listed in table 4. The values presented for the reduction of growing season at increasing altitude can therefore be considered representative.

A compilation of the values for the remaining I4 representative stations results in the following table summary concerning the reduction of the growing season at increasing altitude within various zones (Table 5).

Table 5 shows that the reduction of the growing season at increasing altitudes 
Table 5. Reduction in no. days of the growing season at increasing altitude within various zones

\begin{tabular}{|c|c|}
\hline Zone & $\begin{array}{c}\text { Increase in altitude } \\
\text { per one day reduc- } \\
\text { tion of the growing } \\
\text { season, m }\end{array}$ \\
\hline o-100 & 8 \\
100-300 & I5 \\
$300-500$ & 20 \\
$500-600$ & 24 \\
\hline
\end{tabular}

is not linear but faster at low levels than at high levels. It may be of interest in this context to consider the statement made by I. Bruun in his discussion of the vertical temperature gradient for each month of the year and for four groups of stations selected according to altitude and ventilation conditions. Bruun found that temperature does not decrease linearly with increasing altitude. The gradient of well ventilated stations with relatively small differences is greater than that of stations with similar aeration but with altitudinal differences of $600 \mathrm{~m}$ or more.

Data concerning altitude and the length of the growing season of all the stations discussed are compiled in Fig. 20. In spite of its limitation, the material shows an obvious tendency to stronger curvature toward a longer growing season in the altitude zone below roo $\mathrm{m}$ than in the higher zones. The four northernmost stations at Bodö and Tromsö differ clearly from the other material. This and the conditions described by Fairbairn in Scotland, however, may be naturally explained by the fact that the decrease in temperature and length of the growing season at increasing altitude is assumed to be unequal within various latitudes. It would be desirable to add an expression of the frost frequency and its physiological importance for the length of the growing season. W. TRAnQuillini (I959, II6 pp.) showed for instance that the influence of night frost on photosynthesis in Pinus cembra is less in spring than in autumn. We also know the frost hardiness to be variable within a species. Improved knowledge in this field requires measurements of photosynthesis, and the site climate and values thus obtained should be tested in a yield index.

Since the material of O. LANGLET, in spite of its extent, is influenced by a number of not-zeroed factors and, furthermore, since it is treated according to the unconfirmed assumption of a linear temperature decrease with altitude, only a general picture of the main course of this decrease is obtained. Considering the observations made by Bruun and mentioned above and the author's observations made in this investigation, the latter observations seem 


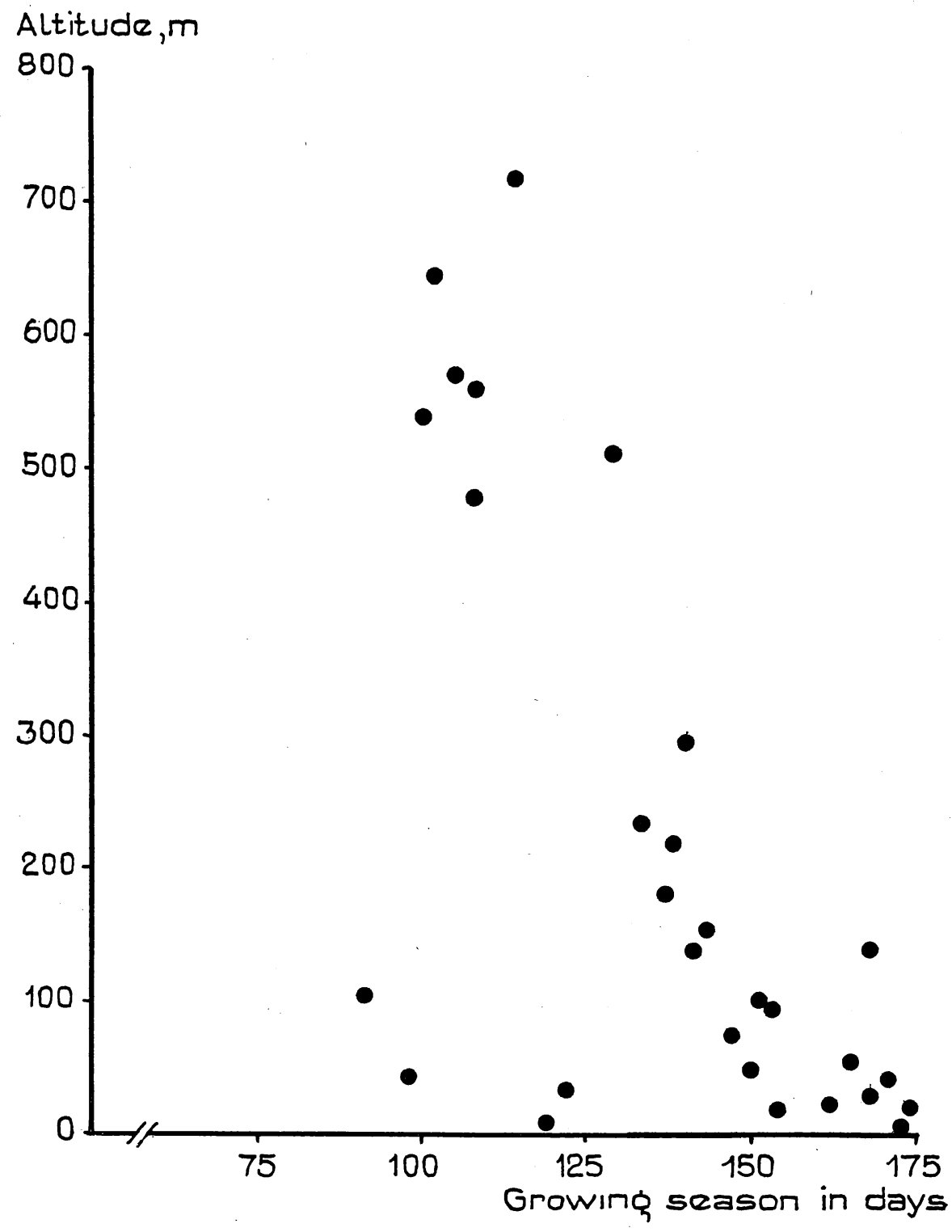

Figure 20. Scatter graph showing the reduction of the growing season at increasing altitudes.

to be most feasible in this context from a theoretical point of view. Practically, the use of one method or the other has no appreciable effect on the CVP index.

Observations made concerning the reduction of the growing season at increasing altitudes will be used for a computation of the growing season of 
climate stations and sample plots which entirely or partly lack meteorological data. Procedure used is according to that described above. Two complete climate stations are selected on each side of the sample plot (or corresponding) and with its connecting line passing through the plot. The growing season of each station is recalculated to the level of the plot according to the proportion of the location of the sample plot on the line connecting the stations. The equal values adjusted in this way constitute the growing season of the sample plot.

The individual sample plots obtain the values presented in Tab. III after necessary adjustments have been made.

The influence of deficiencies remaining in the material in spite of the adjustments made will vary depending on the further treatment. Errors are expressed normally when each climate element is treated separately. When the climate elements are combined, however, the individual errors will enforce or counteract each other. An example will here be presented to show how the errors enforce each other when several climate elements interact.

If a precipitation station situated within a locally and distinctly continental climate area is computed with respect to temperature values it means that values obtained for the mean temperature of the warmest and the coldest months are too low and too high, respectively. These errors are added to each other when the temperature amplitude is computed. A determination of the growing season in no. days on the basis of temperature is also affected by errors in the temperature data. It can generally be stated that the growing season computed will be too short under locally maritime conditions since adjustments for the latter occurrences have not been possible to introduce. Certainly, it would be desirable to eliminate the errors involved. More definite knowledge of the local climate conditions, however, is required and this is possible by means of a meteorological observation station located on the sample plot. 


\section{The relationship between climate and forest yield}

Data compiled in Table III enable a statistical treatment aimed at an establishment of the relationship between climate and yield. As previously stressed the matematical analysis will comprise only the Swedish data on account of their comprehensiveness. Certain general problem complex associated with the concept of production will be discussed before entering into an explanation of the work procedure.

\section{The plant physiological production balance.}

Considering the work methods of the author, J. WECK (I957, p. I24) found that "Zur Gewinnung einer Kennziffer für forstliches Produktionspotential genügt es nicht den Vorgang der Assimilation zu bewerten". The same author returned to this way of reasoning in a later work (I959, p. I2).

WECK supported his statement by means of results from investigations of the production balance of forest stands carried out by P. Boysen-Jensen (I952), C. M. Møller (I945, I954), D. Müller (I954), J. Nielsen (I954), B. Huber (I955), H. Polster and S. Fuchs (I956). WECK obtained data on the distribution of the real production on roots, branches, foliage, respiration and stem for a beech stand on site quality II from Møller, Müller and Nielsen. Special emphasis is thereby given to the remarkable fact that only a third of the real assimilation (gross production) is deposited as utilizable wood.

Using the distribution percentage according to Møller, Müller and Nielsen, WECK is exploratorily computing values for the real production within various climate regions (ibid., I957, p. 225). He then arrived at the statement that respiration is essentially higher in the tropics than in Denmark, but its relative amount in per cent of the real production is not necessarily different. A yield table developed for Pinus merkusii, site class II, by J. H. A. Ferguson (I954) provides an original information for the compilation of the real production of a tropical area (Sumatra). Assuming a certain magnitude of the entire respiration and the ratio between day and night respiration varying with growing season, WECK obtained directly or interpolated yield figures which multiplied by the real production provided a value for the empirically established utilizable portion of assimilation.

The review above is a very concentrated presentation of Weck's attempts to improve the relationship between the $C V P$-index and the forest yield potential. The views presented should be considered for dual reasons; partly they tie in with the geographic variation in this context and partly they emphasize the 
very essential matter of the distribution of the real production by various assimilation products and respiration. It is of importance here to consider the changes in the rate of photosynthesis which are caused for instance by varying geographic latitude and difference in the length of the growing season as well as the intensity of respiration varying at different conditions.

The ratio between the total yield of photosynthesis and respiration $(\mathrm{H}$. Polster: "Ökonomische Atmung”, I95I, p. 54) is of decisive importance for the magnitude of the apparent assimilation, i.e. the amount of carbohydrates made available for the development of various plant parts.

\section{Photosynthesis and respiration in plant parts versus stands}

The process of photosynthesis as well as that of respiration under various conditions with respect to supply of light, heat, moisture and carbodioxide have been explored by the work of several workers e.g. Boysen-Jensen, Burns, Henrici, Heinicke, Holdheide, Huber, Kozlowski, Lundegårdh, Pisek, Polster, Stocker, Stålfelt, Tranquillini, and Zeller. Inspite of the intensive development within this field there are certain gaps in our knowledge which occur as great deficiencies in phyochorological investigations. This is particularly the case of the relationship between the process of photosynthesis in individual plant parts and that of entire tree stands. Investigations carried out by Heinicke and Hoffman and by Heinicke and CHILders seem to indicate that the processes in this respect need not necessarily be similar. Whereas the former research workers found that individual leaves from the apple reached maximum photosynthesis at a light intensity corresponding to a third to a fourth of full sun light, the latter workers stated that the entire apple tree achieved the highest photosynthetic effect only at noon in clear days. A. Pisek and W. Tranguillini (I954) found that the light requirements in dense stands of a species are considerably greater than those of solitary branches from the same tree. The American as well as the Austrian research workers thus confirm the statements made by Boysen-Jensen long ago.

Concerning respiration, too, we know its magnitude under certain conditions (cf. Polster, I95I). However, the same deficiency occurs here as in the case of photosynthesis. Observations made pertain to short time periods, parts of the plants investigated or tender plants and the investigations have usually been made under the periods of the growing season which are most favourable for photosynthesis from a climatic point of view (ibid.). The values obtained are therefore representative only to the limited extent determined by the primary data used. The greatest caution must be exercised when attempts are made to compute values of photosynthesis and respiration for entire forest stands from data obtained from branches or solitary seedlings. Too little is yet known of the simultaneous, physiological processes in a branch, 
a seedling, a tree and an entire stand. The investigations carried out by Heinicke-Hoffman-Childers and Pisek-Tranquillini and mentioned above seem to indicate that the results will be different. Difficulties to find data valid for entire stands from present detail information are further enhanced in view of knowledge provided by micro-climatology concerning the vertical temperature layering in stands. This layering means that the tree crowns are vertically distributed by various temperature zones. Light conditions, too, are different within various parts of the canopy. The interacting influences of the various conditions are not yet sufficiently known to allow the computation of a dependable mean value of the total photosynthesis and respiration of a stand at a given time, and still less with respect to the entire growing season. If feasible equipment is available, analyses of gaseous processes under macro-conditions seem to be avenues that would lead toward a solution.

Previous investigations concerning photosynthesis and respiration comprise only a minor portion of the growing season, i.e. they are made in the course of two-three months and not continuously but in periods of one to several days. A computation of values for the total photosynthesis and respiration from these time-limited data, which furthermore are affected by the methodical deficiencies discussed above, can produce but rough approximations.

Although stating that data now available on photosynthesis and respiration in forest stands per hectare and annum still lack a degree of accuracy sufficient for detailed phyochorological research, we must stress the value of results obtained particularly by comparative investigations of photosynthesis and respiration which have enabled a grouping of our most common species according to their capacity of photosynthesis and economy of respiration. Differences between the species expressed in grams per green-weight, in sq. $\mathrm{cm}$. foliage surface, or for entire stands, are obvious. In conjunction with these comparisons it should be remarked that stand data provide proper relations if the various species display the same yield physiology pattern for the individual tree as well as the stand. The relative values of the annual yield

Table 6. Relative values of the apparent photosynthesis expressed in $\mathrm{kg} \mathrm{C} / \mathrm{ha} / \mathrm{an}-$ num for various species in Germany

\begin{tabular}{|c|c|}
\hline Species & $\begin{array}{c}\text { Relative } \\
\text { values }\end{array}$ \\
\hline Pseudotsuga Douglasii . . & Ioo \\
\hline Fagus silvatica ........ & 73 \\
\hline Picea excelsa $\ldots \ldots \ldots \ldots$ & 60 \\
\hline Larix europea......... & $5^{8}$ \\
\hline Betula verrucosa....... & 48 \\
\hline Quercus robur........ & 34 \\
\hline Pinus silvestris $\ldots \ldots \ldots \ldots$ & 25 \\
\hline
\end{tabular}


of some common species is elucidated by the following table which is computed from values presented by H. POLSTER (I95I, p. 80) for the assimilation surplus (the apparent photosynthesis) calculated in $\mathrm{kg}$ carbon per hectare and annum. The apparatent photosynthesis is obtained by subtracting respiration from the real photosynthesis. The species with the highest surplus has been given the value Ioo and other species proportional values (Table 6).

A somewhat changed order is obtained if corresponding relative values are instead computed on the basis of "Derbholzzuwachs" expressed in $\mathrm{kg} \mathrm{C} / \mathrm{ha} / \mathrm{an}$ num (ibid., p. 8I) for various species in Tab. 7.

Table 7. Relative values of "Derbholzzuwachs" (expressed in $\mathrm{kg} \mathrm{C} / \mathrm{ha} /$ annum for various species in Germany)

\begin{tabular}{|c|c|}
\hline Species & $\begin{array}{c}\text { Relative } \\
\text { values }\end{array}$ \\
\hline Pseudotsuga Douglasii... & xoo \\
\hline Picea excelsa ......... & 59 \\
\hline Fagus silvatica . . . . . . & 53 \\
\hline Larix europea........ & 44 \\
\hline Pinus silvestris . . . . . . & $4 \mathrm{I}$ \\
\hline Quercus robur......... & 40 \\
\hline Betula verrucosa....... & 33 \\
\hline
\end{tabular}

In spite of the changed order the tables show clearly the great mutual differences between the species with respect to yield. The relative values in other climate areas, as well as the mutual order of species typical of other climate types, are still beyond our knowledge.

Computing his reduction values, WECK thus used data on the yield balance of beech and assumed values of photosynthesis and respiration within various climate areas. Against the background of this presentation Weck's procedure seems to produce values of a low degree of dependability. However, the method developed by Weck is of great theoretical interest and it will also be practically valuable as soon as the basis of yield physiological data necessary is developed.

At present phyochorological research must be based on yield data in forestry expressed in cu. m. wood or tons of dry matter. Within uniform climate areas we may expect consistent relationships between photosynthesis, respiration and an "economic" yield measured in cu.m. (tons) of wood. Detailed phyochorological investigations may give information whether the relationships are different for other climate areas. However, it is important to collect the yield data from local strains. 


\section{The investigation method concerning the relationship}

The investigation of the relationship between yield potential and climate has proceeded as follows: a number of scatter graphs were drawn to obtain an exploratory information concerning the relationship; the most suitable graphs were then considered for a regression analysis and determination of the correlation strength.

Experiment I. Initially a scatter graph was established for each age class on the basis of the author's original equation (I956) for the computation of the CVP index where the growing season is expressed in months. All the distribution pictures here show a clear relationship between the variables. No parameters were computed for a determination of this relationship but the pictures obtained were used for a visual comparison with the corresponding presentation in the following experiment.

Experiment 2. It would be desirable from a practical point of view to express already in the formula for $C V P$ the prevailing conditions associated with the computation of the length of the growing season and the minimum requirements of its length. In other words it should be clear from the equation that the growing season is determined by the no. days with a temperature of $+7^{\circ} \mathrm{C}$ or more and that it furthermore must have a minimum duration of 90 days. As stated previously, it may be assumed for logical reasons that a definition in terms of days must give a more accurate value than an expression in months. An equation established on this basis will have the following appearance:

$$
C V P=\frac{T_{v} \times N \times(G-90) \times E}{\left(T_{a}+7\right) \times 270 \times 100} .
$$

For values of $G<90$ this expression of $C V P$ becomes negative, which means that the climate conditions are unsuitable for tree growth. According to the previous discussion $G=90$ would indicate conditions occurring at the tree limit. The advantage of increasing $T_{a}$ by 7 shows particularly for equatorial areas, where the difference between $T_{v}$ and $T_{a}$ is slight. Considerably lower index values are obtained. The dispersion graphs show, however, that a somewhat weakened relationship is obtained for Sweden in comparison with that in experiment I, particularly within the range of low $C V P$-values. This procedure of computation was therefore considered less suitable.

Experiment 3. The next step in the investigation was to study the relationship when $C V P$ was determined according to the formula

$$
C V P=\frac{T_{v} \times N \times G \times E}{T_{a} \times 360 \times 100}
$$


The dispersion graphs established on the basis of this formula for various age classes show a picture very similar to that obtained in experiment I. Further testing by means of statistical computation for the establishment of potential differences was therefore not considered necessary. The latter expression presented here, however, appears most suitable on account of the more distinct definition of composite factors.

Experiment 4. The author stated in his work of I956 (p. 73) that precipitation particularly within the A- and C-climate regions according to the Köppen scheme exert too great an influence on the CVP-index in relation to its effect on the growth potential. The growth appears to show a purely negative response to superhumid amounts of precipitation. It will be shown in the following presentation that the same effect can occur in Norden as well. In this context the annual precipitation consequently gives an unrealistic expression of the growth promoting influence of the water. To correspond to the growth power, the annual precipitation must be reduced by a value representing the surplus water and its negative effects in the form of nutrient leaching etc. However, great difficulties are involved in the establishment of such a reduction factor since it is also dependent on variable factors such as e.g. temperature and site conditions.

O. F. S. TAMM treated in a work (I959) the climatic humidity of Sweden. Humidity $(H)$ was defined as the difference between the annual precipitation and the mean value of the evapo-transpiration. To compute the latter factor Tamm succeeded in establishing a functional relationship with the mean annual temperature. Thus it is possible to establish the evapo-transpiration for each individual point with known temperature value. It would be desirable in this investigation to test an expression of transpiration only in our relationship. The plant physiologically active part of the moisture available would then be represented. Since no such value has been established, it would be interesting to use the Tamm value for evapo-transpiration $(E)$ as a substitute. However, since this value is a function of temperature, we then introduce a new temperature factor and no improvement of the relationship can be expected. Although the humidity values express a humidity where the influence of temperature has been eliminated to the greatest extent possible, they are less useful in this context since they lack the plant physiological influence desired. A weakened relationship was obtained when $E$ and $H$ were tested.

The equation used in experiment 3 appears to be the most suitable one for a computation of the $C V P$-value corresponding to the yield. The relationship obtained in this way is given an exploratory presentation in the dispersion graphs, Fig. 2I-24, one for each age class.

A comparison between the graphs seems to reveal that the function lines have a slightly different position as expressed by the inclination in relation 


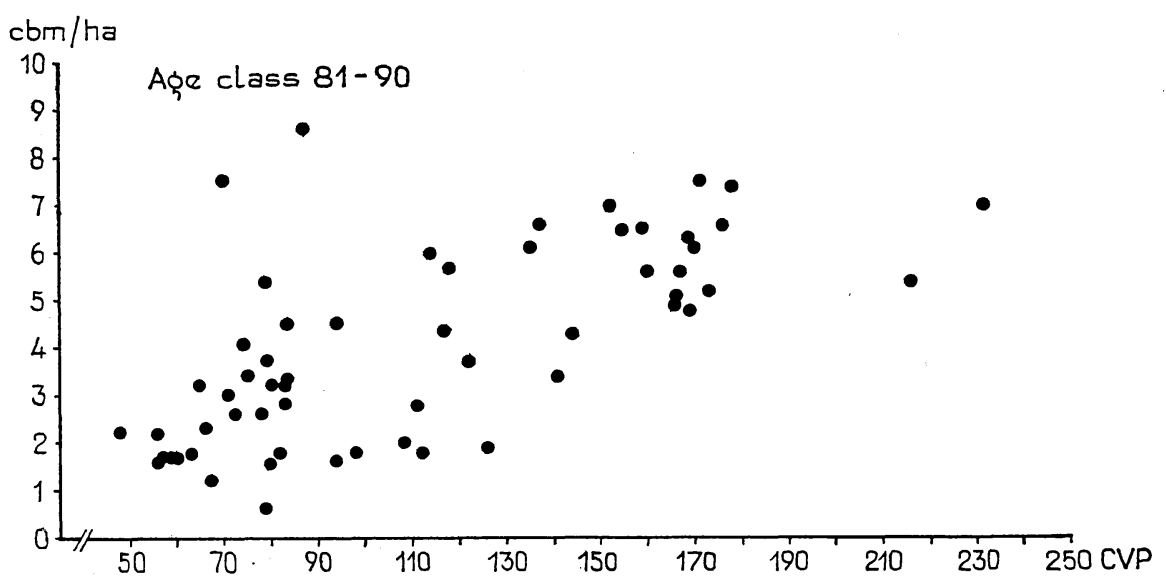

Figure 2r. Scatter graph showing the relationship between $C V P$ and yield, age class $8 \mathrm{I}-90$ years.

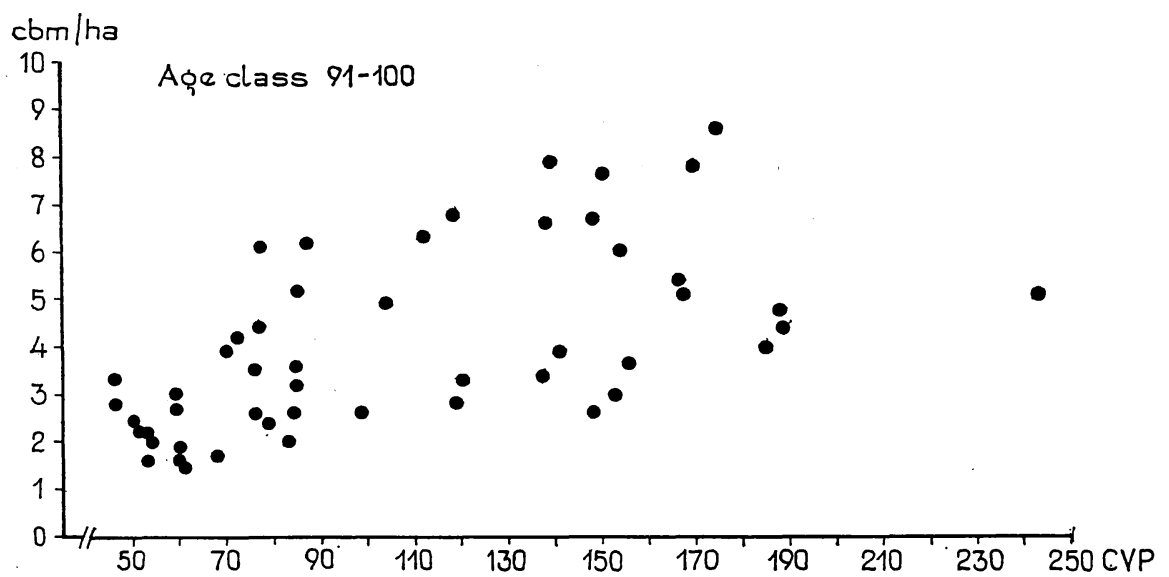

Figure 22. Scatter graph showing the relationship between $C V P$ and yield, age class $9 \mathrm{I}$ - Ioo years.

to the $X$-axis. To ascertain the actual status exactly, the regression function was calculated for each age and for the total material. The functions are presented in Fig. 25, which reveals certain differences. The curve of the age group 9I-Ioo years is most level whereas those of the groups 8I-90 years and III-I20 years are steeper and nearly parallel to each other. The maximum difference at $C V P$-value 200, a point determined by sufficient statistical data, does not fully reach a value of one cu.m per hectare. Discrepancies between the age classes may partly be interpreted as expressions of the fact that the 
$\mathrm{cbm} / \mathrm{ha}$

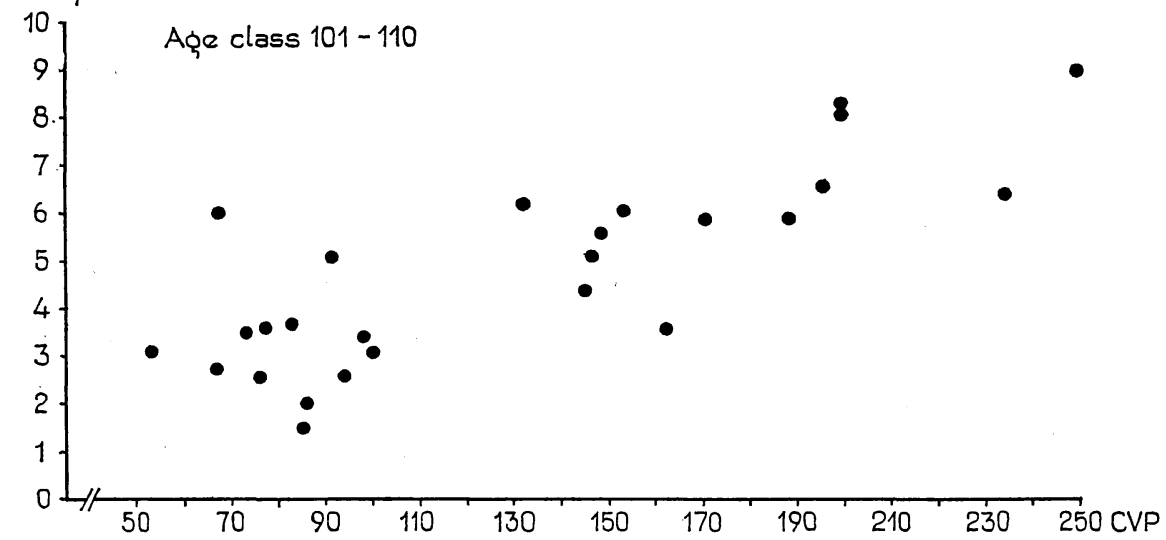

Figure 23. Scatter graph showing the relationship between $C V P$ and yield, age class roI-I Io years.

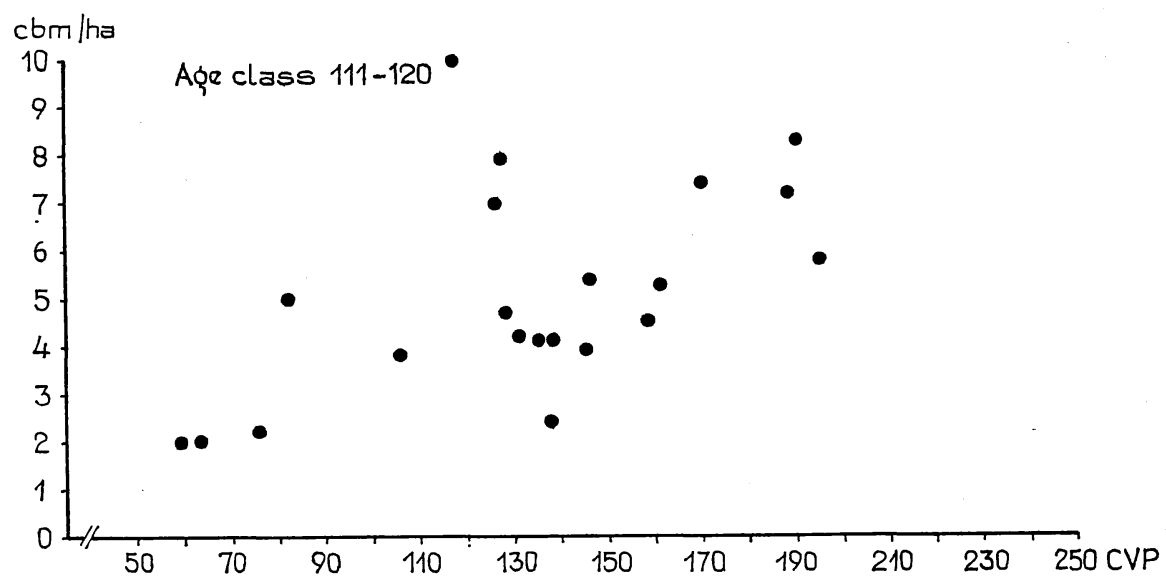

Figure 24: Scatter graph showing the relationship between $C V P$ and yield, age class I I I-I 20 years.

mean increment of the stand culminates at various age in different climate types.

The differences between age classes, however, may also be caused by irregularities in the material of the various age groups. Primarily, the non-climatic yield factors i.e. the edaphic factors, may then be considered. Differences between the age groups may thus be caused by dissimilar distribution of sample plots by soil types, sites of different hydrological properties and sites with different nutritional status etc. To procure 


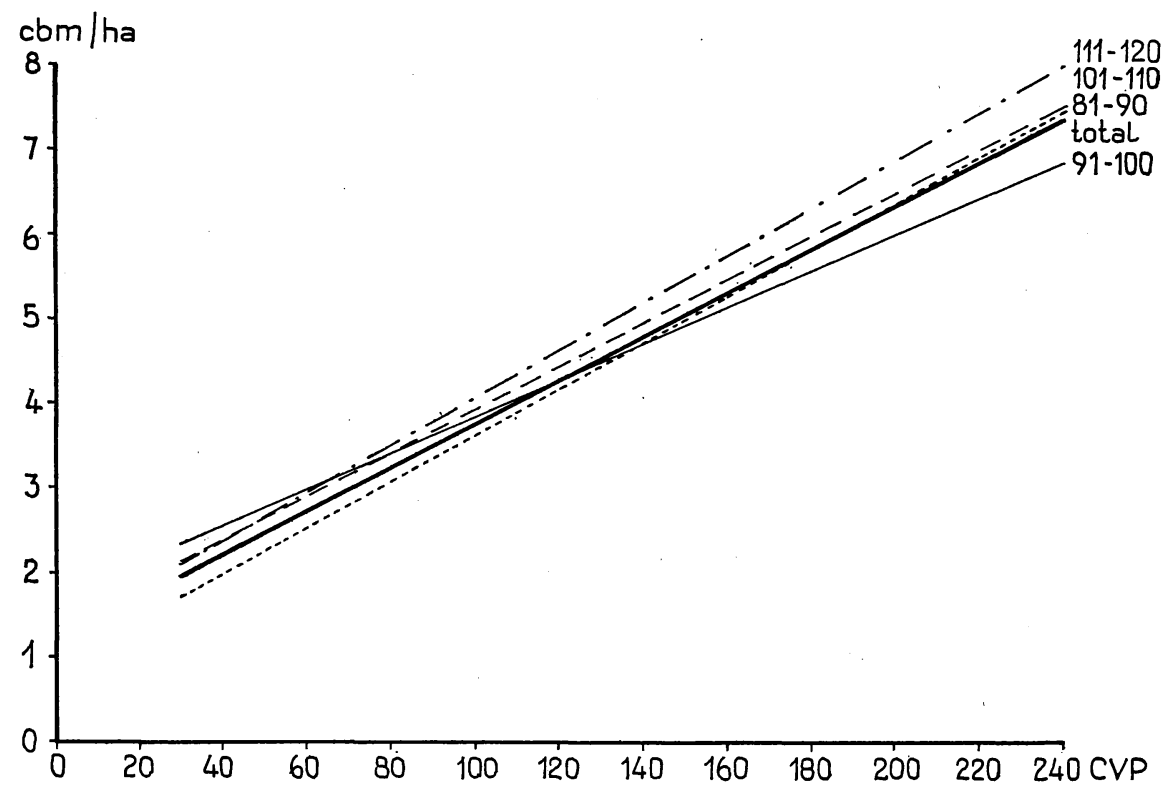

Figure 25. Regression functions for each age class and for the total material.

a survey of our data in these respects, we have investigated their distribution by forest types according to a preliminary physiognomic division carried out by the Forest Research Institute of Sweden on the basis of the scheme classification designed by C. Malmström. This will give an expression of i.a. variations in the hydrological conditions of our plots since the forest types show a clear relationship with the water supply of the sites (C. Malmström, I949, p. I00, f.; ibid., I949, p. 233). The relative distribution of the sample plots by forest types within each age class is shown in the graph, Fig. 26. Displaying great variations between the groups, however, the graphs do not show the geographical distribution of the forest types. If all the plots with Geranium type in an age class are found within the range of low $C V P$-values in our function, this distribution must reduce the slope of the corresponding regression line. This may possibly explain why the age group $9 \mathrm{I}$ - Ioo years displays a deviating position in relation to other age groups. However, further elucidation of this matter requires a more detailed investigation not possible in this context.

After the comparative studies of the dispersion graphs had been concluded to find the best expression suitable for a computation of $C V P$, a complete statistical treatment of the data could be undertaken. The intention was to clarify by regression analysis the importance of each of the factors included in the $C V P$-index for the relationship between the yield and climate. The 


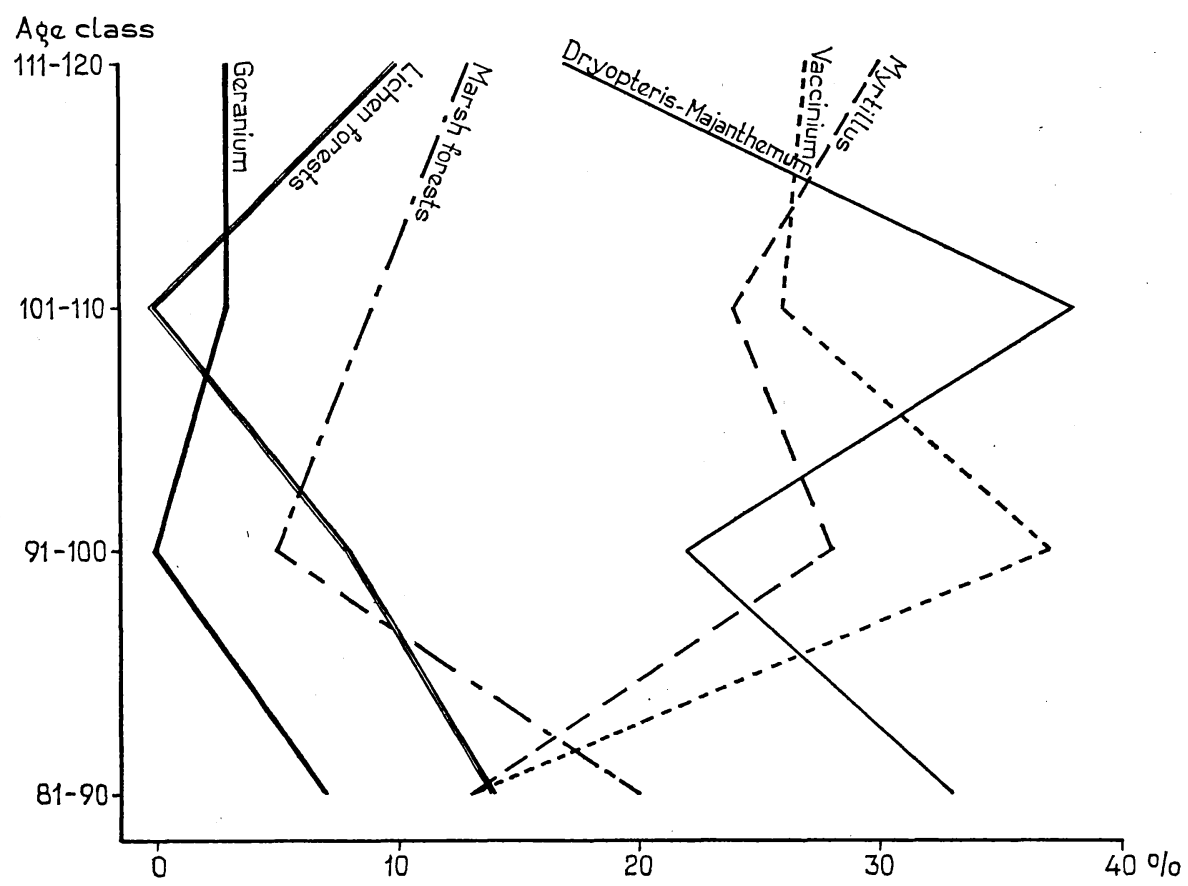

Figure 26. Frequency of the sample plots by forest types in each age class, per cent.

establishment of a correlation matrix would then in addition to the relationship enable a study of the mutual relationships between the composite factors. The statistical computations necessary were carried out under the guidance of Mr. O. Persson, Civ. Eng. at the Forest Research Institute of Sweden, who has also written the following report concerning this work. The meaning of the term $S$, which is an expression of the electric conductivity of the soil, is discussed in a following chapter. The term $E$ has not been included in the computation since it was clear from the very beginning that its importance for an improved fit is slight within the relatively limited area covered by this investigation.

\section{Description of the statistical computations}

By Olle Persson, Civ. Eng.

Notation:

Yield potential in $\mathrm{m}^{3} \mathrm{sk}$ per hectare and annum, allowance made for

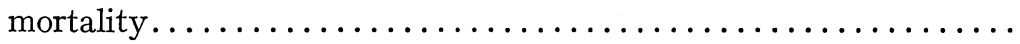

Yield potential in $\mathrm{m}^{3} \mathrm{sk}$ per hectare and annum, allowance not made $y_{1}$ for mortality $\ldots \ldots \ldots \ldots \ldots \ldots \ldots \ldots \ldots \ldots \ldots \ldots . \quad y_{2}$ 
Mean temperature of the warmest month, ${ }^{\circ} \mathrm{C} \ldots \ldots \ldots \ldots \ldots \ldots T_{v}$

Temperature range (difference between the mean temperature values of the warmest and the coldest months) $\ldots \ldots \ldots \ldots \ldots \ldots \ldots, T_{a}$

Precipitation (mean annual value in $\mathrm{mm}$ ) $\ldots \ldots \ldots \ldots \ldots \ldots \ldots, N$

Length of growing season in days.................... $G$

Electric conductivity of the site...................... $S$

Paterson's index $\frac{T_{v} \cdot N \cdot G \cdot E}{T_{a} \cdot 360 \cdot \text { I00 }}: \ldots \ldots \ldots \ldots \ldots \ldots \ldots \ldots \ldots \ldots \ldots$

( $E=$ insolation according to pages 47 and 69 ).

Observations are made concerning $y_{1}, y_{2}, T_{v}, T_{a}, N, G, S$ and $C V P$ for a total of I74 plots.

\section{Computations.}

Both series of $y_{1}$ and $y_{2}$ have first been fitted graphically by means of a number of regression functions the most important of which are reported in the following presentation (Tables 8-9). Quadratic terms of $N$ and $S$ and $\frac{T_{v}}{T_{a}} \cdot G$ have also been tested in thel investigation but they have not improved the fit. Fit is approximately equal in both series, and this is shown by the dispersion of the function in per cent of that of the total mean value decreasing similarly. The absolute dispersion, however, is greater for the $y_{1}$-series than that for the $y_{2}$-series. Only the $y_{1}$-series was therefore investigated in some supplementary analyses. This was also carried out for the four age classes 8I-90 years, $9 \mathrm{I}-\mathrm{IOO}$ years, IOI-IIO years, and III-I20 years, which are represented by $60,49,3 \mathrm{I}$, and 22 plots, respectively (Table Io). Within these groups some functions which had produced significant indications at the first tests, were investigated. The regression analysis has been supplemented with a computation of both the total and the partial correlation coefficients up to third order. The correlation coefficients could be derived from the regression coefficients and their standard errors by simple computations. The analysis has been carried out for the total material by means of a standard programme for regression analysis with the electronic computing machine, Facit EDB; the subgroups have been calculated by means of manual computations.

In the following presentation not only the functions but also the standard errors of the coefficients and the standard deviations of the $y_{1}$ - and $y_{2}$-values of the functions are reported. Dispersion may be considered a measurement of the variations of observational errors and the influences of various unknown factors that may affect the yield. Moreover, dispersion values are presented in per cent of the dispersion of the total mean values of the $y_{1}$ - and the $y_{2}$-series. The functions obtained within the groups for the relationship between $y_{1}$ 
Table 8. Regression functions, yield potential adjusted for natural thinning (volume of mortality).

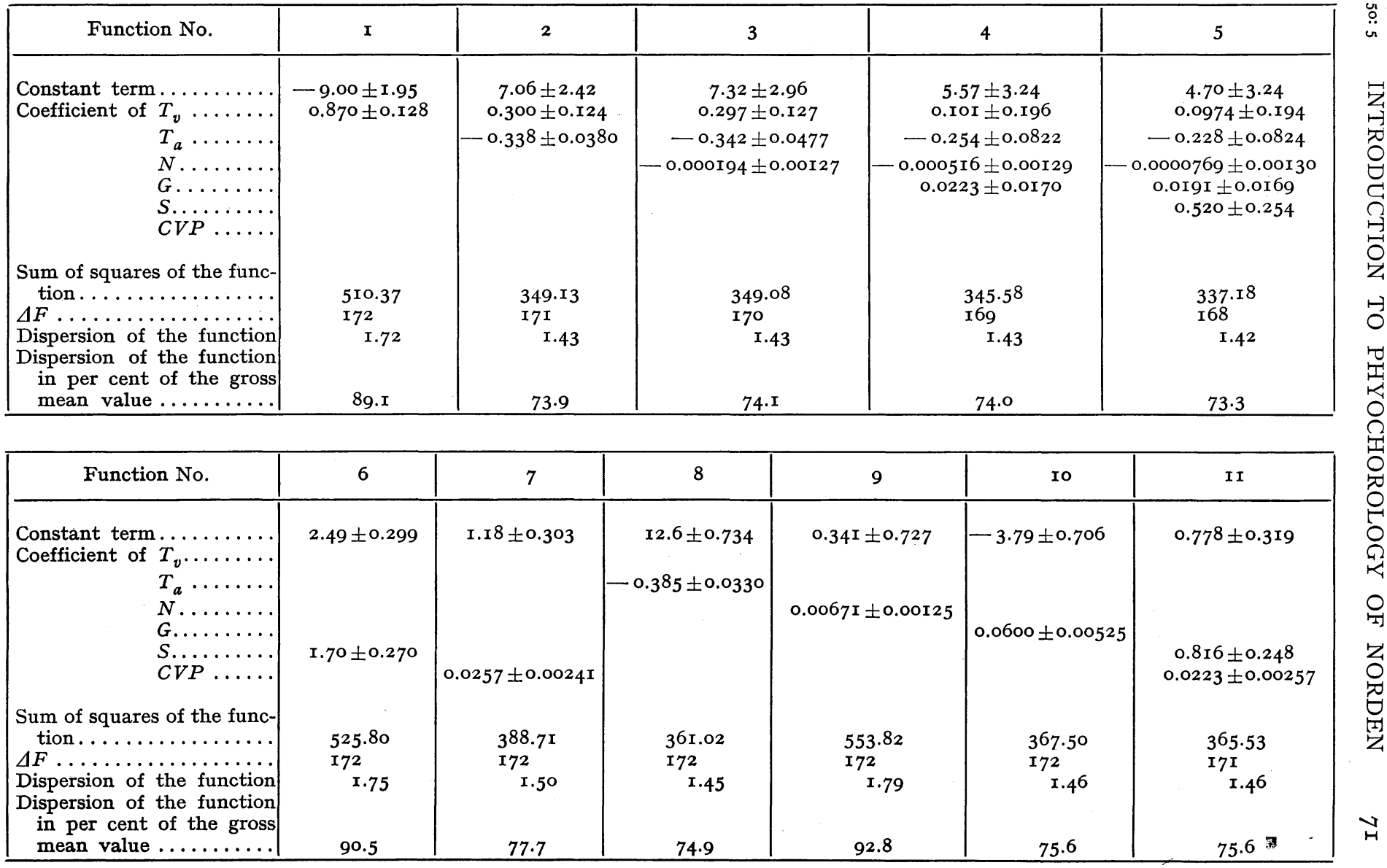


Table 9. Regression functions, yield potential not adjusted for natural thinning (volume of mortality).

\begin{tabular}{|c|c|c|c|c|c|c|c|}
\hline Function No. & $\mathbf{I}$ & 2 & 3 & 4 & 5 & 6 & 7 \\
\hline 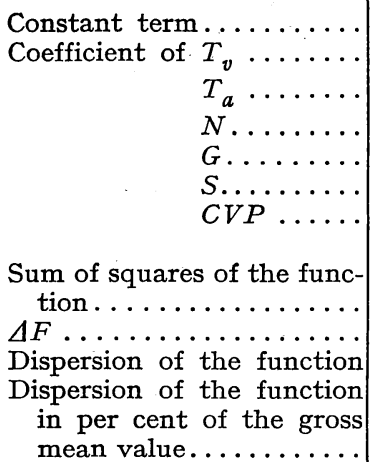 & $\begin{array}{l}269.69 \\
172 \\
\quad I, 25 \\
\\
90.6\end{array}$ & $\begin{array}{l}\text { I } 87 \cdot 39 \\
\text { I } 7 \mathrm{I} \\
\quad \text { I,05 }\end{array}$ & $\begin{array}{c}5.62 \pm 2.17 \\
0.179 \pm 0.0927 \\
-0.236 \pm 0.0349 \\
0.000235 \pm 0.000933\end{array}$ & $\begin{array}{c}4.65 \pm 2.38 \\
0.0704 \pm 0.144 \\
-0.187 \pm 0.0603 \\
0.0000562 \pm 0.000950 \\
0.0124 \pm 0.0125 \\
\\
\\
186.24 \\
169 \\
1,05\end{array}$ & $\begin{aligned} & 4.05 \pm 2.38 \\
& 0.0677 \pm 0.142 \\
&-0.169 \pm 0.0606 \\
& 0.000361 \pm 0.000957 \\
& 0.0102 \pm 0.0124 \\
& 0.361 \pm 0.187 \\
& \\
& \text { I82.18 } \\
& \text { I68 } \\
& \mathrm{I}, 04 \\
& 75.3\end{aligned}$ & $2.12 \pm 0.215$ & $\begin{array}{c}\text { I.I } 7 \pm 0.219 \\
0.018 \mathrm{I} \pm 0.00 \mathrm{I} 74\end{array}$ \\
\hline
\end{tabular}

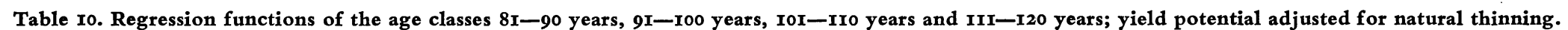

\begin{tabular}{|c|c|c|c|c|}
\hline Age class & $8 I-90$ years & 9I-Ioo years & IOI-IIo years & III-I20 years \\
\hline $\begin{array}{l}\text { Constant term } \ldots \ldots \ldots \ldots \\
\text { Coefficient of } C V P \ldots \ldots \ldots \\
\text { Sum of squares of the func- } \\
\text { tion } \ldots \ldots \ldots \ldots \ldots \ldots \ldots \ldots \ldots \\
\Delta F \ldots \ldots \ldots \ldots \ldots \\
\text { Dispersion of the function } \\
\text { Dispersion of the function } \\
\text { in per cent of the gross } \\
\text { mean value............. }\end{array}$ & $\begin{array}{c}0.906 \pm 4.836 \\
0.0272 \pm 0.00422 \\
\\
\text { I33.89 } \\
58 \\
1.52\end{array}$ & $\begin{array}{c}\mathrm{x} .692 \pm 4.834 \\
0.02 \mathrm{I} 4 \pm 0.00445 \\
\\
\mathrm{x} 03.73 \\
47 \\
\mathrm{I} .49 \\
82.8\end{array}$ & $\begin{array}{c}\text { I.343 } \pm 0.616 \\
0.0254 \pm 0.00467 \\
\\
5 \text { r.04 } \\
29 \\
\text { I.33 } \\
7 \text { r.6 }\end{array}$ & $\begin{array}{c}\mathrm{I} .262 \pm \mathrm{I} .240 \\
0.0280 \pm 0.00939\end{array}$ \\
\hline
\end{tabular}




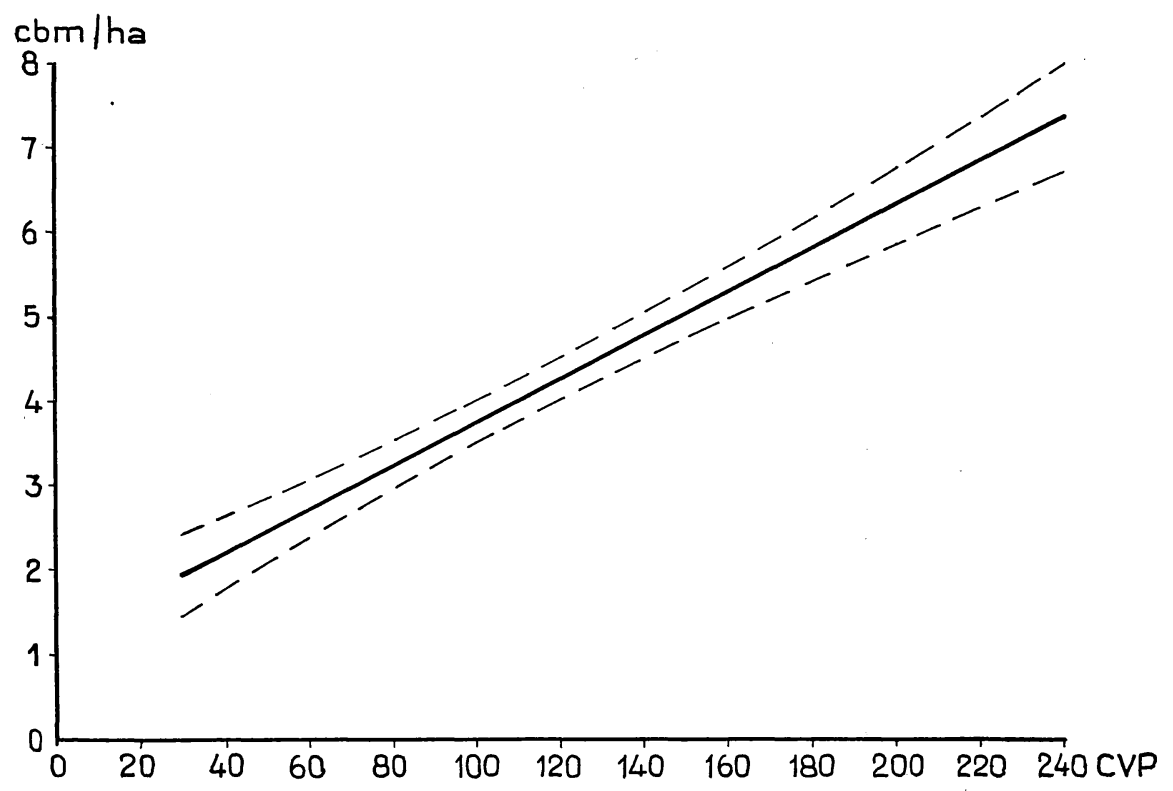

Figure 27. The theoretical regression line of the total material and the 95 per cent confidence belt.

and CVP are drawn in Fig. 25, which also shows this relationship for the total material. In Fig. 27 there is also a 95 per cent confidence belt for the theoretical regression line of the total material. No testing of the hypothesis that the groups can be totalled has been carried out since the total material contains some additional observations which have been too few to be totalled into independent groups. An ocular evaluation of the figure, however, does not seem to disprove the hypothesis. The correlation coefficients are finally reported in a matrix for the total material (Table II), where most of the factors have been compiled, and in four smaller matrices (Tables I2-I5) for the groups with but a few factors.

Nor have the hypotheses of the correlation coefficients been tested. Finally, it must be stressed that significance criteria used at regression analysis are based on certain assumptions which are often fitted in series of observations of the kind presented here. These assumptions also underlie the estimates reported for the standard errors and the correlation coefficients. One must therefore often make the reservation in a context of this kind that a significance may be more formal than real. In spite of this reservation the analysis still has its value when compared with other results obtained on a logical basis. 
Table Ir. Partial and total correlation coefficients for the total material.

\begin{tabular}{|c|c|c|c|c|c|c|c|c|c|c|c|c|c|c|c|c|c|c|c|c|c|c|}
\hline & & .2 & $\cdot 3$ & $\cdot 4$ & .6 & .8 & .IO & .23 & .24 & .26 & .28 & .210 & $\cdot 34$ & $\cdot 36$ & $\cdot 38$ & .3IO & .46 & .48 & .410 & .68 & $6 \mathrm{Io}$ & .810 \\
\hline$T_{v}$ & II 2 & - & 0.18 & 0.42 & -0.08 & 0.36 & 0.12 & - & - & - & - & 一 & 0.18 & 0.05 & o.16 & o.14 & -0.07 & 0.34 & - 0.12 & -0.08 & -0.05 & -0.09 \\
\hline$T_{a}$ & II 3 & -0.56 & - & -0.59 & -0.24 & $-0.5^{8}$ & -0.30 & - & -0.48 & -0.23 & -0.50 & -.030 & - & - & - & - & -0.24 & -0.50 & -0.20 & -0.22 & $-0.2 \mathrm{I}$ & -0.25 \\
\hline$N$ & II 4 & 0.33 & -0.04 & - & 0.04 & 0.35 & $-0.3 \mathrm{I}$ & $-0.0 \mathrm{I}$ & - & $0.0 \mathrm{I}$ & 0.32 & $-0.3 \mathrm{I}$ & - & -0.04 & -0.01 & -0.22 & - & - & - & 0.07 & -0.17 & -0.25 \\
\hline$G$ & II 6 & 0.53 & 0.20 & 0.62 & 一 & 0.57 & 0.26 & o.I0 & 0.44 & - & 0.48 & $3 \mid 0.24$ & 0.20 & - & 0.18 & o.I5 & - & 0.48 & 0.03 & - & - & $0.2 \mathrm{I}$ \\
\hline$S$ & II 8 & 0.33 & o.19 & $0.4 \mathrm{I}$ & 0.18 & - & 0.24 & 0.16 & $0.3 \mathrm{I}$ & O.I8 & - & 0.23 & 0.18 & 0.16 & - & o.r9 & O.I9 & - & 0.16 & - & o.19 & - \\
\hline$C V P$ & II IO & 0.50 & 0.13 & 0.60 & 0.12 & 0.55 & -1 & 0.07 & 0.49 & 0.10 & 0.45 & - & 0.25 & 0.03 & 0.13 & -1 & 0.20 & $0.5 \mathrm{I}$ & -1 & o.13 & -1 & - \\
\hline
\end{tabular}

\begin{tabular}{|c|c|c|c|c|c|c|c|c|c|c|c|c|c|c|c|c|c|c|c|c|c|c|}
\hline & & .234 & .236 & $.23^{8}$ & $.23 \mathrm{I}$ & .246 & .248 & .2410 & .268 & $.26 \mathrm{IO}$ & $.28 \mathrm{IO}$ & $\cdot 34^{6}$ & $\cdot 348$ & $\cdot 3410$ & $\cdot 368$ & $\cdot 3610$ & $\cdot 3810$ & .468 & .4610 & $.48 \mathrm{Io}$ & $.68 \mathrm{Io}$ & $\begin{array}{l}\text { Total } \\
\text { corr. }\end{array}$ \\
\hline$T_{v}$ & II 2 & - & 一 & - & - & - & - & - & 一 & - & - & 0.04 & 0.16 & -0.03 & 0.04 & 0.05 & 0.12 & -0.06 & -0.12 & - o.ro & -0.05 & $0.4^{6}$ \\
\hline$T_{a}$ & II 3 & - & - & 一 & - & -0.23 & -0.42 & - o.16 & $-0.2 \mathrm{I}$ & $-0.2 \mathrm{I}$ & -0.26 & - & - & - & - & - & - & $-0.2 \mathrm{I}$ & -0.20 & -0.18 & - o.19 & -0.66 \\
\hline$N$ & II 4 & - & -0.03 & $0.0 I$ & -0.16 & - & - & - & 0.04 & -0.20 & -0.25 & - & - & - & -0.02 & - o.15 & -0.18 & - & - & - & -0.14 & $0.3^{8}$ \\
\hline$G$ & II 6 & o.Io & - & 0.09 & 0.07 & - & 0.38 & 0.05 & - & - & 0.20 & - & 0.18 & -0.02 & - & - & 0.12 & - & - & 0.03 & - & 0.66 \\
\hline$S$ & II 8 & 0.16 & 0.16 & - & o.r7 & 0.19 & - & 0.15 & - & o.19 & - & 0.16 & - & o.I 4 & - & o.16 & - & - & 0.16 & - & 一 & 0.43 \\
\hline$C V P$ & II IO & 0.18 & 0.03 & 0.08 & - & 0.23 & 0.42 & -1 & O.12 & - & - & O.I5 & 0.22 & - & 0.04 & - & - & 0.18 & - & - & - & 0.63 \\
\hline
\end{tabular}


Table r2. Correlation matrix for age class $81-90$ years.

\begin{tabular}{|c|c|c|c|c|c|c|c|c|}
\hline & & Total & .2 & $\cdot 3$ & . 10 & .23 & .210 & .310 \\
\hline$T_{v}$ & II 2 & 0.39 & - & 0.23 & 0.12 & - & - & 0.22 \\
\hline$T_{a}$ & II 3 & -0.72 & -0.68 & 一 & $-0.4 \mathrm{I}$ & - & -0.45 & - \\
\hline CVP & II IO & 0.65 & 0.57 & 0.04 & - & -0.05 & - & - \\
\hline
\end{tabular}

Table 13. Correlation matrix for age class 91-I00 years.

\begin{tabular}{|c|c|c|c|c|c|c|c|}
\hline & Total & .2 & $\cdot 3$ & . IO & .23 & .210 & .310 \\
\hline II 2 & 0.46 & - & o.I 6 & 0.12 & 一 & 一 & 0.12 \\
\hline II 3 & -0.57 & $-0.4 \mathrm{I}$ & - & $-0 . I_{4}$ & 一 & -0.14 & - \\
\hline II IO & 0.57 & $0.4 \mathrm{I}$ & o.I7 & - & 0.12 & $\longrightarrow$ & 一 \\
\hline
\end{tabular}

Table I4. Correlation matrix for age class ror-Iro years.

\begin{tabular}{|c|c|c|c|c|c|c|c|}
\hline & Total & .2 & $\cdot 3$ & . ro & .23 & .210 & .310 \\
\hline II 2 & $0.3 I$ & - & -0.27 & -0.27 & - & - & -0.36 \\
\hline II 3 & -0.72 & $-0.7 \mathrm{I}$ & 一 & -0.30 & - & -0.38 & - \\
\hline II IO & $0.7 \mathrm{I}$ & 0.70 & 0.26 & 工 & 0.36 & - & - \\
\hline
\end{tabular}

Table 15. Correlation matrix for age class III-I20 years.

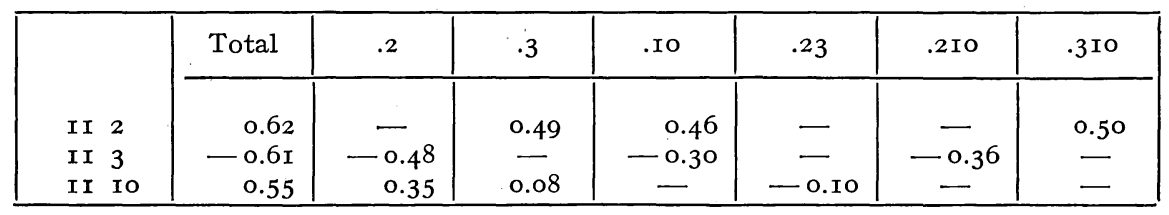

\section{The results of the statistical computations}

The computations carried out by $\mathrm{O}$. Persson show that the temperature amplitude has the strongest influence on the yield of the climate factors considered. A similar feature, although appreciably weaker, is characteristic of $T_{v}$ and $N$, to the same extent of $T_{a}$ and the growing season $G$. On account of the interdependence between terms, their influence on the yield is best described only by $T_{v}$ and $T_{a}$ according to function No. 2 .

$$
\text { (2) } y=7.06+0.300 T_{v}-0.338 T_{a}
$$

Function No. 2 is valid within the limits of the geographical space where the sampling is made with its mutual relationships between the components of climate. This relationship is not constant and thus not generally valid for all climate areas. It must instead be conceived of as varying to the same extent 
as one or other of the climate elements diminishes toward the limit where it acquires the nature of a minimum factor. According to general experience, temperature is the climate element most decisive for growth in Sweden. The functional relationship in equation 2 must therefore be considered entirely logical. Yet, it is covering only 26 per cent of the variations in the material whereas the remaining 74 per cent refer to not observed factors and measurement errors. It is interesting against the background of views expressed to study the degree of fit when $C V P$ is used as variable. We then obtain function No. 7 .

$$
\text { (7) } y=\mathrm{I} . \mathrm{I} 8+0.0257 \mathrm{CVP}
$$

The parameters of the dispersion of this function show slightly inferior values in comparison with corresponding values for function 2. From a statistical point of view, however, function 2 appears as the better one of all those established here on the basis of climate data. It has previously been shown (St. St. Paterson, I956) how the CVP-index covers the mutually varying relationships of the composite factors to give them comparable expression. The best example is provided by the conditions prevailing at the boundaries of dry deserts and cold deserts. Although these areas are conditioned by entirely different minimum factors, precipitation and temperature, respectively, the $C V P$-index presents the same value for both boundaries. In spite of the changed mutual order of the magnitude of the influence of these climate elements on the growth power, they give the same result if entered in the equation for $C V P$.

With the exception of certain strongly humid areas in relation to their surroundings, the discussion above pertains to interregional comparisons based on mean values for yield and on the data of a generalized macro-climate. In the present investigation, where absolute yield values have been used, it has appeared necessary to produce data for the local climate of each site. As shown in a previous chapter these are essential requirements not least with respect to water supply. The division of the Nordic countries into three ombro-hygro-thermal regions shows that the water supply and annual precipitation of individual localities do not run parallel to each other. Nor do they constitute synonymous expressions of the bio-effect since they instead exhibit great variations in this respect. To achieve a better fit, it is necessary to find a suitable expression of the hygrometric conditions of the sites during the growing season and then to replace the annual precipitation with this value in our function.

Table Io contains the regression functions in the four most important age classes for yield with respect to the $C V P$-index. The best relationship occurs within the group IOI-IIO years, which appears to have both the lowest 
dispersion parameters and the highest correlation coefficient, $r=0.7$ I. Its function is:

$$
y=\mathrm{I} .343+0.0254 C V P
$$

This function shows by means of a determination coefficient $\left(r^{2}\right)$ of 0.50 that the factors included cover 50 per cent of the variation of the yield values. The reason for the superior fit in this age group cannot be interpreted as a special age dependence but may be considered dependent on the reduced influence of not included factors on account of the selection.

The relationship of the individual climate elements with the growth potential has been analysed for the total material in Table II.

The total correlation coefficient of $T_{v}, r=0.46$, represents a weak relationship. The partial correlation coefficients inform that $T_{v}$ is strongly correlated with both $T_{a}$ and $G$.

$$
r_{11 \text { 2,3 }}=0.18 \quad r_{112.6}=-0.08 \text { and } \quad r_{11 \text { 2.3.6. }}=0.05
$$

The temperature range and the growth potential are obviously correlated, the correlation coefficient being $r_{113}=0.66$. It is interesting to find that this correlation is considerably less influenced by $T_{v}, r_{113.2}=-0.56$, than the latter factor is correspondingly influenced by $T_{a}$ according to the previous paragraph. Considerable influence is exerted by $G$ on $T_{a}$ since the correlation coefficient decreases to $r_{11 \mathbf{3 . 6}}=-0.24$, if $G$ is kept constant. Accessory correlation coefficients of the second and third order cannot impair the latter correlation to any appreciable extent.

Of all climate factors considered, precipitation has the weakest influence on the variation of yield, $r_{114}=0.38$. The correlation coefficients of higher order show that precipitation is a variable depending on temperature range and growing season to a considerably larger extent than the latter factors are depending on precipitation.

The growing season shows a clear relationship with the growth potential, $r_{116}=0.66$. This relationship is strongly influenced by $T_{a}, r_{116.3}=0.20$ and weakly by $T_{v}, r_{116.2}=0.53$. Precipitation has no pronounced influence.

Observations now made concerning the correlation conditions are supported by the partial coefficients for yield and $C V P$-index as variables, shown on the last line in the matrix (Table II).

The partial and total correlation coefficients presented in Table Ir are based on correlation conditions valid for the site. If corresponding correlation coefficients are available and valid for average yield conditions within approximately the same area, i.e. that of Sweden, a comparison between the coefficients of the two groups would provide valuable information particularly concerning the general influence of the edaphic factors. Correlation coef- 
fients of the kind desired, except for the growing season, have been computed by the author with the benevolent assistance of Mr. U. Zachrisson, Ph. Lic. of the statistical institution at the University of Gothenburg (ST. ST. Paterson, manuscript p. 20). The material comprises a total of $4 \mathrm{I}$ yield data, 27 of which orginate from Sweden, I from Norway and Denmark, respectively, 3 from U.S.A. I from each of Canada, Cameroun, Nigeria and Java, and 5 from Germany. On account of the dominance of the Swedish material and the closely similar Norwegian, Danish, German and Canadian data, the statistical comparability with the present site material should be satisfactory, although not complete. The two groups of material have been compiled in the following table, Table I6.

Table I6. Partial and total correlation coefficients for the relationships between some climate elements and the yield of the site $(L)$ and that of the average (M)

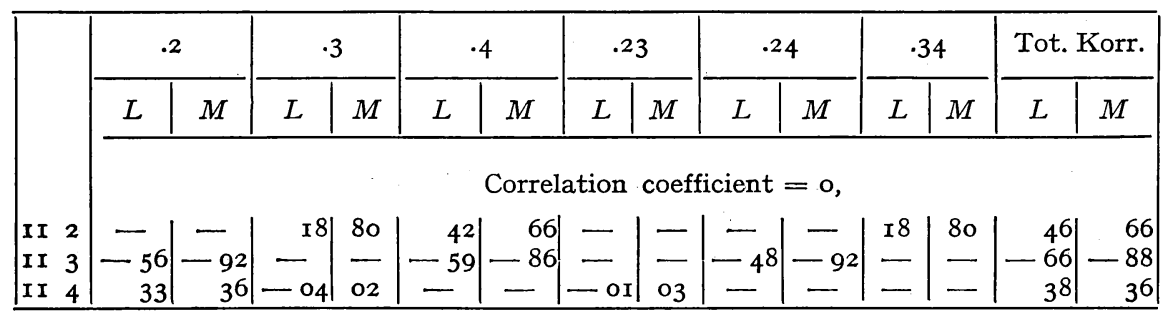

The total correlation coefficients indicate a considerably stronger relationship within the $M$ groups for the two temperature variables, whereas precipitation has an almost equally weak influence on the variation of yield within both the groups. This feature of precipitation is further evidenced by the partial correlation coefficients. One of the correlation coefficients, $r_{114.3}=-0.04$ and 0.02 respectively, indicates that precipitation is so strongly related to the temperature range that the importance of the former factor for the correlation is already expressed by $T_{a}$. This observation, however, is not to be generalized but is valid only for conditions within the limits of the material. This condition is valid for all the comparisons made in this context. The total correlation coefficients for II.2 and II.3 are both lower in the $L$-group than those in the $M$-group. The influence of unconsidered factors has thus been greater within the former group. The partial correlation coefficients indicate this increased influence to affect the $T_{a}$-factor to the greatest degree. This influence primarily pertains to the edaphic conditions. Observations now made consequently indicate that the two expressions of temperature describe the general yield conditions better than the conditions prevailing on the local site. Improved fit should be achieved by means of direct data on the site climate. 
The partial and the total correlation coefficients presented in the tables I2-I5 give a picture of the correlations studied which is more similar to the total material. Here, too, the strong influence of the factor $T_{a}$ is clearly manifested within each age group.

The weakness in our data on yield caused by the stand composition factor $(Z)$ has repeatedly been mentioned in the preceding discussion. This influence will be elucidated as a completion of our statistical analysis. On the basis of the values presented in Table I for the stand composition, the portion of Scots pine is computed and entered as a new variable after which we obtain the regression functions presented in Table I7.

The regression functions show that the stand composition has an obvious influence on the mean increment. The lowest parameter values for dispersion found in this study are recorded in function I7. This is the case also with the functions 18 and 19 in comparison with corresponding functions where $C V P$ index is included and obtained previously (Table 8). Function I7, however, cannot be used since three fourths of its values are not significant.

\section{Comparison with the potential productivity of other Nordic countries}

The applicability of the regression functions now obtained may be tested by a comparison with yield data for localities in Denmark, Finland and Norway. The comparison, however, cannot be expected to provide complete agreement because of deviating features in the material which will be elucidated in the following presentation. Since no data concerning the electric conductivity of the sites are available from the other Nordic countries, no equations containing this term have been applicable. The best regression function then appeared to be function No. I6 (Table I7).

$$
y=6.80-0.019 T_{v}-0.177 T_{a}-0.0013 N+0.0295 G-0.0217 Z
$$

However, as shown by the table, several of the values included in this function are not significant. For this reason and to avoid the time-consuming data processing involved in the solving of the next best function No. I4 for each sample plot and the subsequent comparison of the value obtained with that recorded, the author has found it most suitable to use the function No. I8 in which the CVP-index is included. The slightly greater dispersion of this latter function is not so great that the comparison is appreciably impaired. Since it is impossible to express an opinion of the probability of one function or the other and since they are not directly comparable, it is not possible on statistical basis to say which is the most suitable one to use. The choice must rest on logical arguments.

Function No I8: $y=3.47+0.0204$ CVP $-0.0222 Z$

Omitting $Z$, we have previously (Table 8, p. 7 I) obtained function No. 7 
Table I7. Regression functions showing the influence of stand composition on the yield potential. Allowance made for mortality (natural thinning).

\begin{tabular}{|c|c|c|c|c|c|c|c|c|}
\hline Function No. & I2 & I3 & I4 & I5 & I6 & I7 & I 8 & I9 \\
\hline 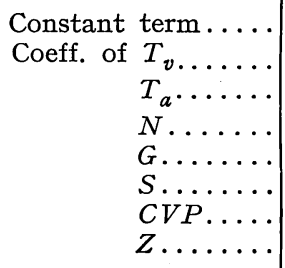 & $+7.210 \pm 0.407$ & $\begin{array}{r}-3.066 \pm x .973 \\
+0.6399 \pm 0.1206\end{array}$ & $\begin{array}{r}+7.9156 \pm 2.3156 \\
+0.2573 \pm 0.1187 \\
-0.277 \pm 0.0387 \\
\\
-0.020 \pm 0.0047\end{array}$ & $\begin{array}{l}+9.0427 \pm 2.8380 \\
+0.2424 \pm 0.1209 \\
-0.2950 \pm 0.0466 \\
-0.0008 \pm 0.0012 \\
\\
-0.0208 \pm 0.0048\end{array}$ & $\begin{array}{l}+6.8026 \pm 3.0745 \\
-0.0187 \pm 0.1868 \\
-0.1769 \pm 0.0796 \\
-0.0013 \pm 0.0012 \\
+0.0295 \pm 0.0162 \\
-0.0217 \pm 0.0047\end{array}$ & $\begin{array}{l}+5.9669 \pm 3.0727 \\
-0.02 \mathrm{II} \pm 0.185 \mathrm{I} \\
-0.1529 \pm 0.0797 \\
-0.0009 \pm 0.0012 \\
+0.0264 \pm 0.016 \mathrm{I} \\
+0.4929 \pm 0.2403 \\
-0.0215 \pm 0.0047\end{array}$ & $\begin{array}{l}+3.465^{8} \pm 0.5^{866} \\
\\
+0.0204 \pm 0.0026 \\
-0.0222 \pm 0.0050\end{array}$ & $\begin{array}{l}+3.0272 \pm 0.5850 \\
\\
+0.7830 \pm 0.2352 \\
+0.0172 \pm 0.0027 \\
-0.0217 \pm 0.0048\end{array}$ \\
\hline $\begin{array}{l}\text { Sum of squares of } \\
\text { the function .... } \\
\text { Degrees of freedom } \\
\text { Dispersion of the } \\
\text { function } \ldots \ldots \ldots \\
\text { Dispersion of the } \\
\text { function in rela- } \\
\text { tion to that of the } \\
\text { total mean value, } \\
\text { per cent ....... }\end{array}$ & 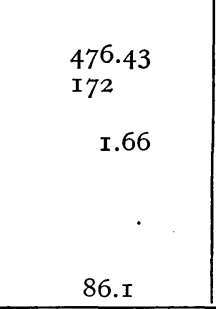 & $\begin{array}{l}408.69 \\
\text { I } 71 \\
\quad \text { I. } 55\end{array}$ & $\begin{array}{l}3 \mathrm{I} 4.49 \\
\mathrm{I} 7 \mathrm{O} \\
\quad \mathrm{I} .36\end{array}$ & $\begin{array}{l}313 \cdot 32 \\
\text { I } 69 \\
\\
\text { I.36 }\end{array}$ & $\begin{array}{l}\begin{array}{l}307.30 \\
\text { I } 68\end{array} \\
\quad \text { I.35 }\end{array}$ & $\begin{array}{l}\begin{array}{l}299.76 \\
\text { I } 67 \\
\text { I. } 34\end{array} \\
\end{array}$ & 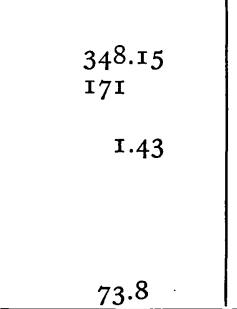 & $\begin{array}{l}326.74 \\
\text { I } 70 \\
\quad \text { I.39 }\end{array}$ \\
\hline
\end{tabular}




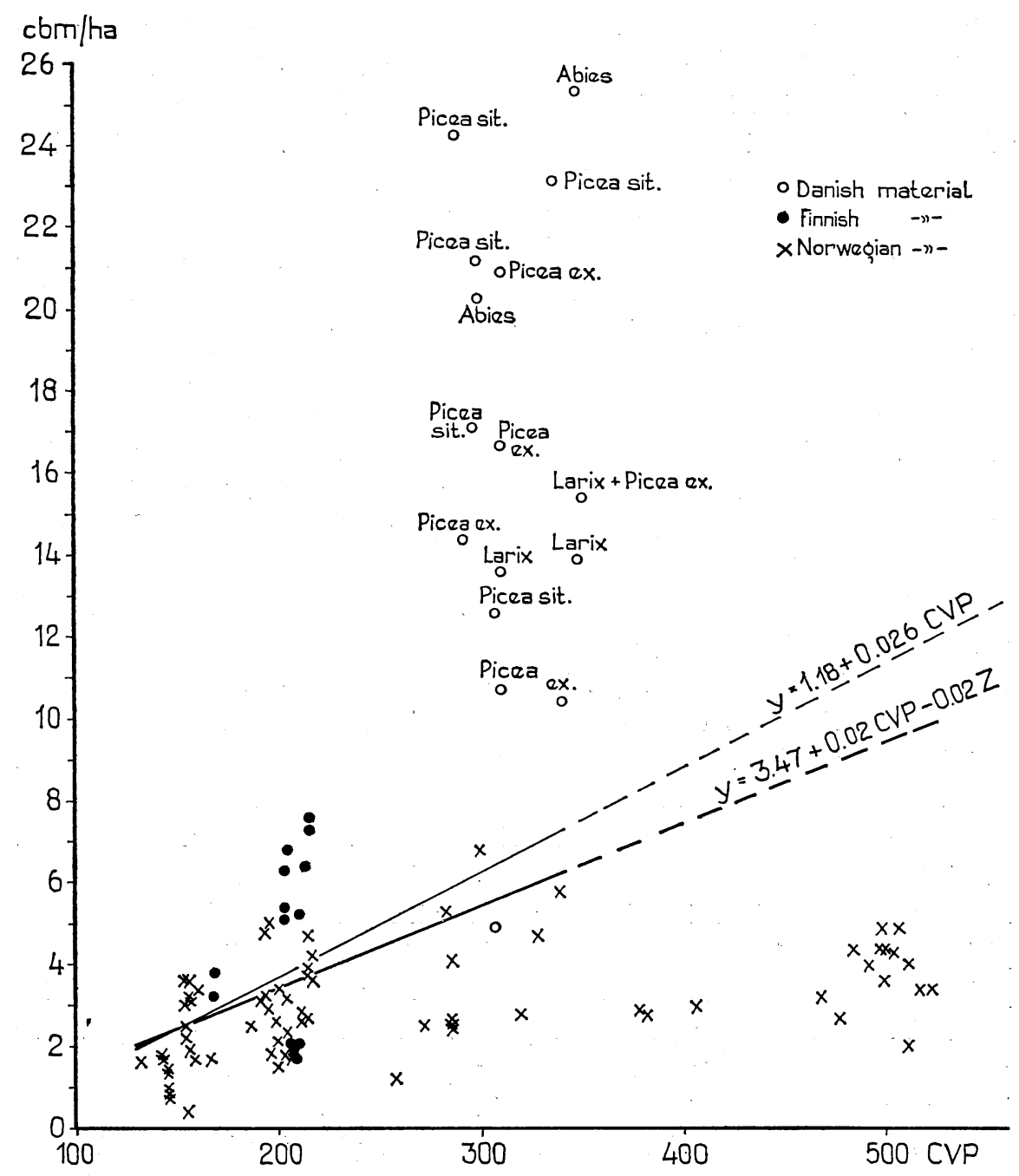

Figure 28. Relationship between the yield and climate of the site in the Nordic countries. Comparisons between scatter graphs and regression functions.

for the total Swedish material, $y=$ I.I8 + 0.026 CVP. Its relationship to function No. $I 8$ is of interest to study in this context.

The functions Nos. 7 and $I 8$ as well as the material representing the countries of comparison are expressed in Fig. 28 by means of a scatter graph for yield with respect to $C V P$.

The material representing Denmark comprises I5 sample plots with I6 increment values. With one exception the latter values are found in Fig. 28 
to be decidedly higher than the other material of comparison. Moreover, the Danish yield values are scattered in the graph without obvious relationship to $C V P$. Dispersion is considerable. The reasons for this are to be found primarily in two circumstances; species and rich soil. The sample plots represent four species, all of which are exotics. Since the stands are also established by planting, they are alien to this investigation.

Data on the mean increment from I4 sample plots in virgin stands have been made available from Finland. The values deviate slightly from the Swedish ones by being based on volume above the ground whereas the Swedish values are computed for the volume above the stump. The Finnish values are therefore estimated to exceed the Swedish values by $\mathrm{I}-2$ per cent. Allowance has been made for mortality. The stand composition is more heterogeneous than that in the Swedish material. Thus, six of the plots are representing pure Scots pine stands, two plots contain more than 50 per cent Scots pine whereas the other plots contain spruce or birch as predominant species (cf. notes to Table III). The plots have the variable soil texture composition typical of the moraine with the exception of four plots where sand is predominant. (Y. VuokILA, acc. to letter). The statistically limited material thus displays great differences. Nevertheless, it shows a certain agreement with the Swedish regression functions according to Fig. 28. The best agreement is obtained for the pure Scots pine stands on moraine soils. The lowermost points are referring to the Scots pine plots on sand. The influence of the edaphic factors on dispersion is obvious. Due to the small extent of the material it is unknown whether it represents average or extreme yield conditions. A comparison between Finnish and primarily Swedish mean yield seems to indicate that extreme elements may be involved in the Finnish data, cf. author's scatter graph of I956 (ST. ST. PATERson, I956, p. 79)". This comparison shows that the Finnish mean yield of various forest districts is lower than the material of comparison in most cases.

The Norwegian data originate from 73 sample plots in virgin stands. The stands are pure Scots pine with the exception of eight plots with inmixture of spruce or broad-leaved species not exceeding four per cent. This maximum inmixture pertains to one plot only whereas the other plots display an admixture of only some promille. The volume computation has been carried out according to certain standards at the Forest Research Institute of Sweden. The material has benevolently been made available by the Norwegian Forest Research Institute under the supervision of A. BRANTSEG. As shown in the map, Plate I, the sample plots are not evenly distributed over the country but more in groups. To obtain a more even geographical distribution, some attempt's were made to include some plots in virgin spruce stands. This appeared impossible, however, since the spruce stands were too young. Con- 
cerning the northernmost plots in the upper part of the Pasvik river, it should be noticed that the culmination age is approximately 200 years. In the case of western Norway no suitable material is available.

The dispersion of the Norwegian material in our graph, Fig. 28, shows certain essential, specific features. We generally find for Scots pine a closer agreement with the adjusted function than with the unadjusted one. More especially it appears that the point scatter at $C V P$-values up to about I30 is rather evenly distributed on both sides of the function and with moderate dispersion. At still higher $C V P$-values, however, the points are increasingly situated below the function and its continuation which is statistically unsupported and in the figure is dashed. We here have an obvious proof of the influence of precipitation. In the $C V P$-range $130-260$ are plots, all of which are located in the interior of South Norway, i.e. largely the province of Telemarken, where precipitation ranges between 800 and I,000 $\mathrm{mm}$. CVP-values above 260 obtain their high value on account of abundant precipitation exceeding $I, 000$ $\mathrm{mm}$ a year. The high values of precipitation mean that the real forest yield will be 25 per cent below the level indicated by $C V P$ as a climatic potential. This great difference is caused by the dual effect of precipitation. Partly it affects $C V P$ to a far greater extent than that corresponding to its growth power promoting effect and partly it impairs the site conditions particularly by a leaching of easily soluble nutrients. The latter effect of high amounts of precipitation has been elucidated by $\mathrm{O}$. Arrhenius in an investigation of the chemical denudation in the mountaineous regions (O. ArRHENIUS, I957). In spite of favourable, mineralogically rich rock, the sites are here the poorest sites in Scandinavia and the nutrient concentration display a clear decrease at increasing amounts of precipitation. Similar conditions are most likely prevailing within the parts of Norway now discussed. Another reason contributing to the gap between yield and CVP may be the incompatibility of the species to the site. Our discussion is based on yield data of Scots pine which prefers light and not too moist sites. It is therefore reasonable to suggest that sample plots represented in the graph by $C V P$ values higher than I6o would be higher yielding with other species, assuming they are suitable from an edaphic point of view as well.

The excessively strong influence of high precipitation values on the CVP. index stated above, shows that precipitation should be introduced as a variable in the expression of index at a reduced value. During attempts to find a suitable form of reduction, $\sqrt{N}$ instead of $N$ was introduced in the expression of CVP. Simultaneously, the yield values were cleaned from data pertaining to sample plots situated on sedimentary soils. The no. sample plots useful for this investigation was thereby reduced from I74 to I49. The ulterior motive of this measure was an attempt to produce a more uniform material from an edaphic 
point of view. As a result dispersion of $C V P$ decreased more (6 per cent) than that of the individual climate elements (4 per cent).

In the following regression analysis some signs of radicals other than $\sqrt{N}$ were also tested (Table I8). The analysis shows that only $\sqrt{N}$ affects the relationship and then by improvement. The subsequent equation is thus obtained for the material treated.

$$
C V P_{1}=\frac{T_{v} \cdot \sqrt{N} \cdot G \cdot E}{T_{a} \cdot 360 \cdot 100}
$$

The effect of substituting $N$ for $\sqrt{3}^{3} \bar{N}$ on the relationship has not been tested. An improvement does not appear probable if Fig. 29 and Fig. 30 are compared. A division of the material into two groups representing southern and northern Sweden is made in the graphs simultaneously with a report of the entire material. Northern Sweden here comprises Norrland and the province of Kopparberg, southern Sweden the rest of the country. It appears that the curves representing the functions with $C V P_{1}$ are very closely located whereas those with $C V P$ obviously part, particularly with respect to South Sweden in relation to the other curves. The graphs also show that the functional relationship for northern Sweden is climbing faster than that for southern Sweden, which implies a curvilinear relationship. The curvature, however, is largely

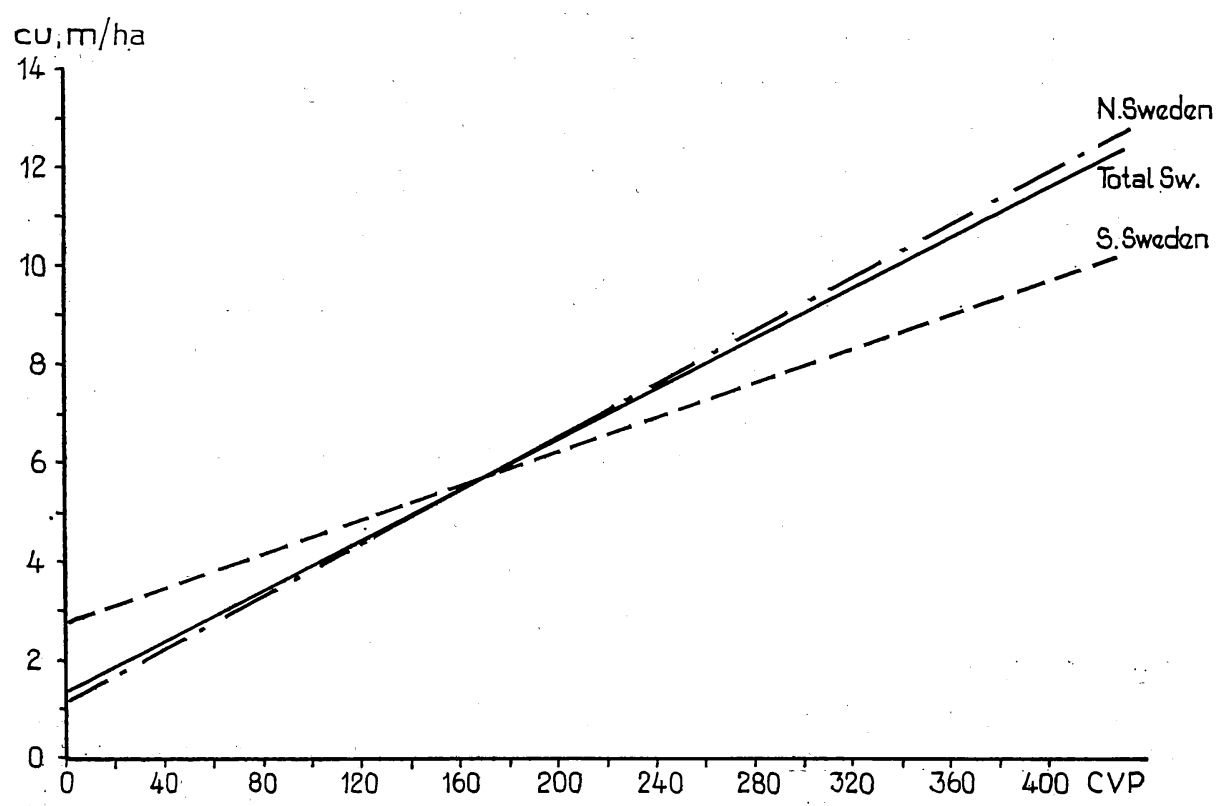

Figure 29. Relationships between yield and CVP for southern and northern Sweden, respectively, and for the whole of the country. 
straightened by the introduction of $\sqrt{N}$ in the graphic presentation shown in Fig. 30. The regression line for the whole of Sweden entered in Fig. 30 provides a better and more realistic picture of the relationship than function No. 7 (Table 9) previously obtained. Our new function No. 6 (Table I8) is written as follows:

$$
y=0.443+0.8 \mathrm{I}_{4} C V P_{1}
$$

Being most suited methodically, this function will be applied in the computation of the potential yield in a subsequent chapter.
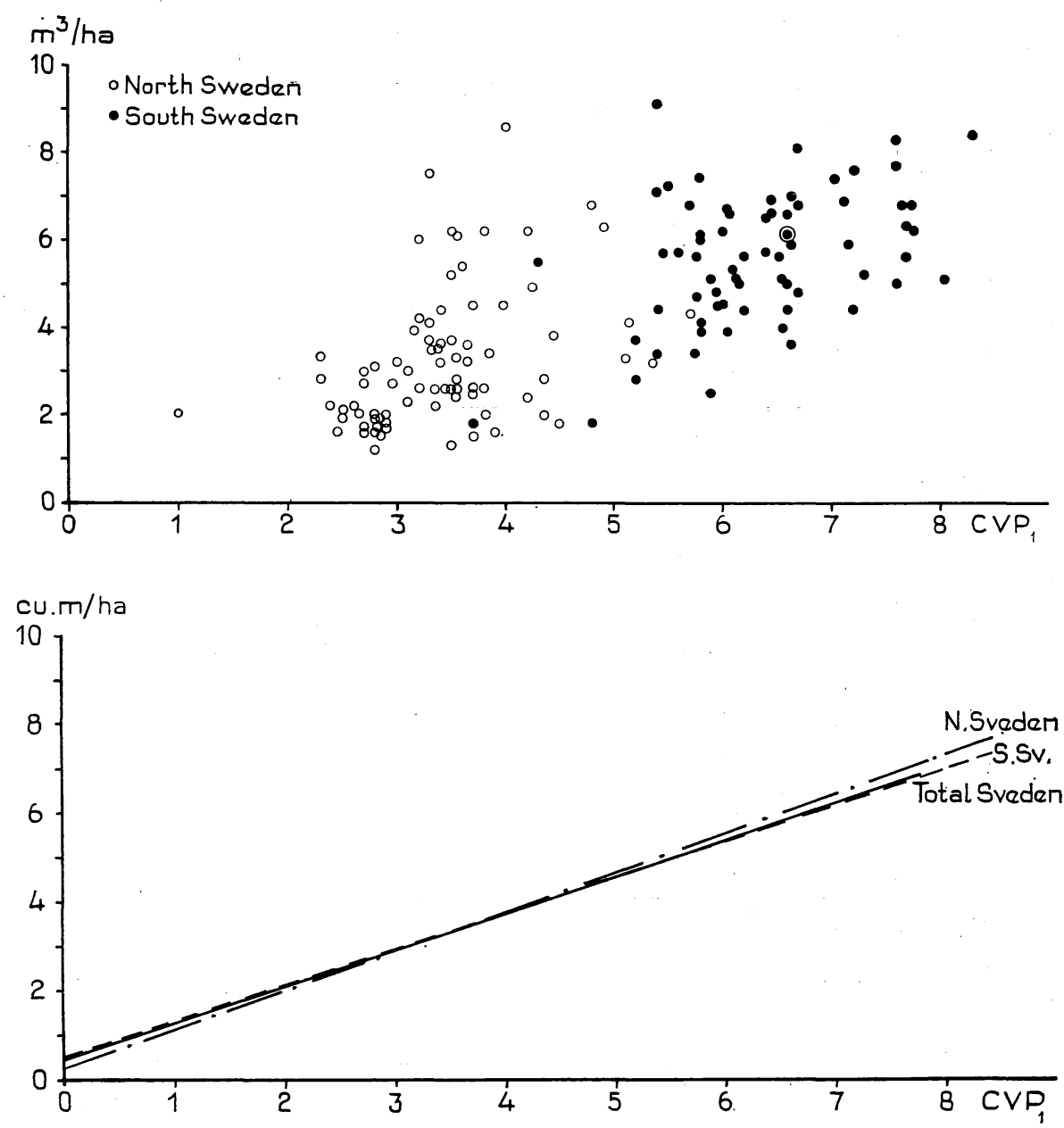

Figure 30. Relationships between yield and $C V P_{1}$ for southern and northern Sweden, respectively, and for the whole of the country. 


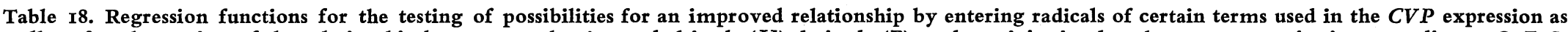

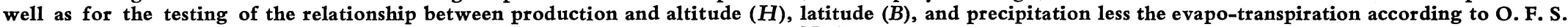
Tamm (N-E).

\begin{tabular}{|c|c|c|c|c|c|c|c|}
\hline Function No. & $\mathrm{I}$ & 2 & 3 & 4 & 5 & 6 & 7 \\
\hline 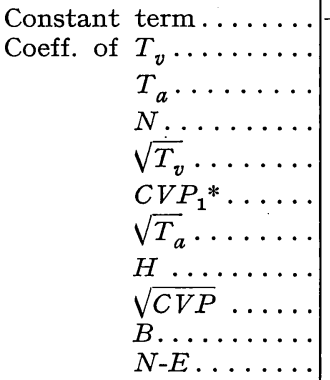 & $\begin{array}{r}\text { II } .0 \pm 2.00 \\
\text { I.OI } \pm 0.132\end{array}$ & $\begin{array}{r}\mathrm{r} 3.3 \pm 0.746 \\
-0.408 \pm 0.0334\end{array}$ & $\begin{array}{l}0.590 \pm 0.769 \\
0.0065 \pm 0.00131\end{array}$ & $\begin{array}{r}-26.1 \pm 3.98 \\
7.83 \pm 1.02\end{array}$ & $\begin{array}{l}22.3 \pm \mathrm{r} \cdot 48 \\
-3.84 \pm 0.3 \mathrm{I} 5\end{array}$ & $\begin{array}{l}0.443 \pm 0.344 \\
0.8 \mathrm{r}_{4} \pm 0.0685\end{array}$ & $0.559 \pm 0.0522$ \\
\hline 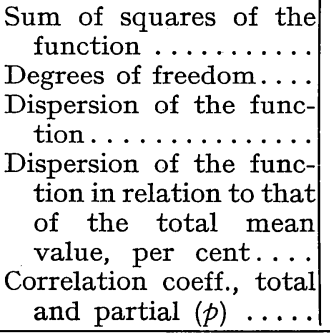 & $\begin{array}{l}399.29 \\
\text { I } 47 \\
\quad \text { I. } 65\end{array}$ & 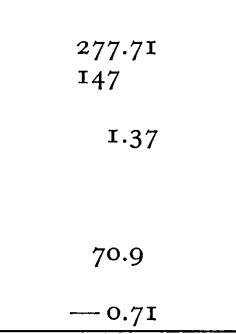 & 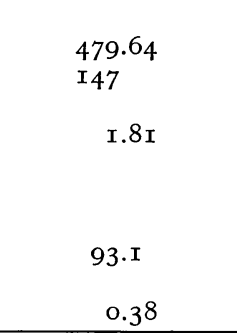 & $\begin{array}{l}400 . \mathrm{II} \\
\mathrm{I} 47 \\
\quad \mathrm{I} .65\end{array}$ & 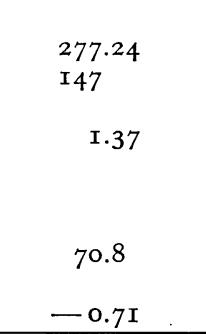 & 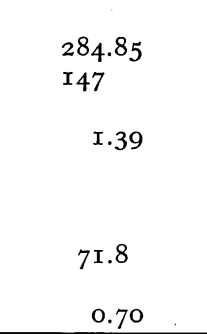 & $\begin{array}{l}313.79 \\
\text { I } 47 \\
\quad 1.46\end{array}$ \\
\hline
\end{tabular}

*CVP $1=\frac{T_{i} \cdot \sqrt{N} \cdot G \cdot E}{T_{a} \cdot 360 \cdot 100}$ 


\begin{tabular}{|c|c|c|c|c|c|c|c|}
\hline Function No. & 8 & 9 & Io & II & 12 & I3 & I 4 \\
\hline 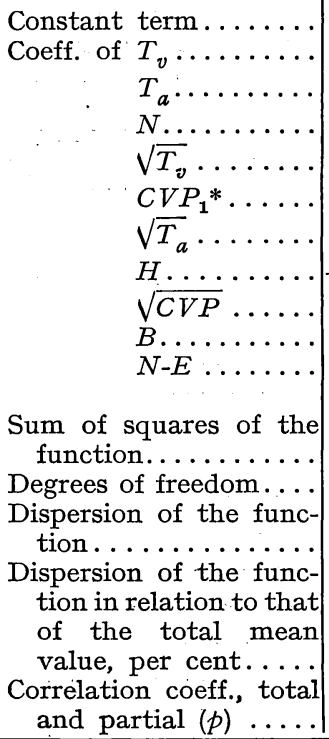 & $\begin{array}{r}6.07 \pm 0.273 \\
-0.00776 \pm 0.00104\end{array}$ & $27 \cdot 9 \pm 2.10$ & $\begin{array}{c}4.84 \pm 0.487 \\
-0.00205 \pm 0.00176 \\
553 \cdot 76 \\
\text { I } 47 \\
\text { I. } 94\end{array}$ & $\begin{array}{c}-4 . \mathrm{I} 3 \pm 4.0 \mathrm{I} \\
0.6 \mathrm{I} 5 \pm 0.242 \\
\\
-0.0037 \mathrm{I} \pm 0.00189\end{array}$ & $\begin{array}{c}-0.3 \mathrm{I} 7 \pm 0.0420 \\
287.08 \\
\mathrm{I} 46 \\
\mathrm{I} .40\end{array}$ & $\mid \begin{array}{c}\text { o.00I } 42 \pm 0.00157 \\
397.04 \\
146 \\
1.65 \\
\\
85.0 \\
0.08(p)\end{array}$ & $\begin{array}{c}\text { I } 2.7 \pm 0.733 \\
-0.34^{2} \pm 0.0364 \\
-0.0035^{6} \pm 0.000940\end{array}$ \\
\hline
\end{tabular}

${ }^{*} C V P_{1}=\frac{T_{v} \cdot \sqrt{N} \cdot G \cdot E}{T_{a} \cdot 360 \cdot 100}$ 


\begin{tabular}{|c|c|c|c|c|c|c|c|}
\hline Function No. & I 5 & I6 & I 7 & I 8 & I9 & 20 & $2 x$ \\
\hline 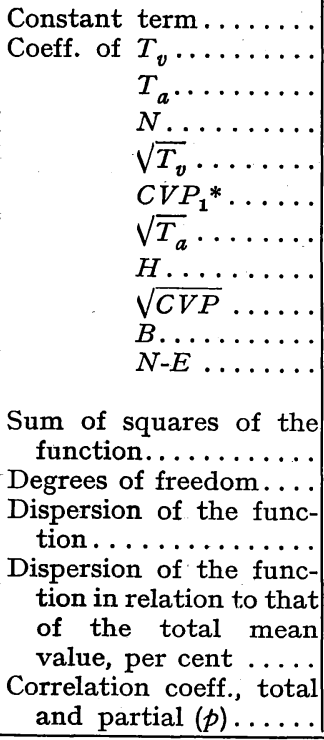 & $\begin{array}{c}-14.7 \pm 4.29 \\
-0.374 \pm 0.107 \\
-0.0344 \pm 0.105 \\
277.5 \mathrm{I} \\
\mathrm{I} 46 \\
\text { I.38 }\end{array}$ & $\begin{array}{c}-0.00294 \pm 0.00123 \\
267.28 \\
146 \\
\mathrm{r} .35\end{array}$ & $\begin{array}{l}\text { 355. I7 } \\
\text { I } 46 \\
\quad \text { I.6o }\end{array}$ & $\begin{array}{c}-0.00262 \pm 0.00140 \\
-0.442 \pm 0.0460 \\
293.67 \\
146 \\
1.42 \\
73.1 \\
-0.62(p)\end{array}$ & $\begin{array}{c}\text { I.35 } \\
-0.02 \text { I0 } \pm 0.00195 \\
267.76 \\
\text { I } 46 \\
69.8 \\
-0.67(p)\end{array}$ & $\begin{array}{l}252.46 \\
\mathrm{I} 45 \\
\mathrm{I} \cdot 3^{2} \\
68.0 \\
-0.16(p)\end{array}$ & $\begin{array}{r}0.98 \mathrm{I} \pm 5.83 \\
0.454 \pm 0.136 \\
-0.427 \pm 0.105\end{array}$ \\
\hline
\end{tabular}

- $C V P_{1}=\frac{T_{v} \cdot \sqrt{N} \cdot G \cdot E}{T_{a} \cdot 360 \cdot 100}$ 


\begin{tabular}{|c|c|c|c|c|c|c|}
\hline Function No. & 22 & 23 & 24 & 25 & 26 & 27 \\
\hline 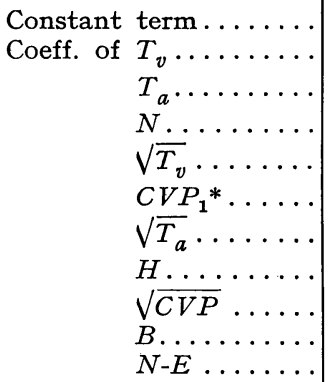 & $\begin{array}{c}7.37 \pm 2.82 \\
0.344 \pm 0.137 \\
-0.354 \pm 0.0397\end{array}$ & $\begin{array}{c}-0.00282 \pm 0.00163 \\
0.0294 \pm 0.115\end{array}$ & $\begin{array}{c}\mathrm{Ir} .6 \pm 3.75 \\
0.082 \mathrm{I} \pm 0.205 \\
-0.347 \pm 0.0396 \\
\\
-0.00267 \pm 0.00156 \\
-0.00122 \pm 0.00133\end{array}$ & $\begin{aligned} 4.23 & \pm 6.57 \\
0.379 & \pm 0.152 \\
-0.407 & \pm 0.106\end{aligned}$ & $\begin{array}{c}-0.00266 \pm 0.00164 \\
0.00415 \pm 0.119 \\
-0.00120 \pm 0.00137\end{array}$ & $\begin{aligned} 5.63 & \pm 2.47 \\
0.4 \mathrm{Ir} & \pm 0.127 \\
-0.34 \mathrm{I} & \pm 0.0383\end{aligned}$ \\
\hline $\begin{array}{l}\text { Sum of squares of the } \\
\text { function............ } \\
\text { Degrees of freedom ... } \\
\text { Dispersion of the func- } \\
\text { tion } \ldots \ldots \ldots \ldots \ldots \ldots \\
\text { Dispersion of the func- } \\
\text { tion in relation to that } \\
\text { of the total mean } \\
\text { value, per cent } \ldots \ldots \\
\text { Correlation coeff., total } \\
\text { and partial }(p) \ldots \ldots .\end{array}$ & $\begin{array}{l}256.09 \\
\mathrm{I} 45 \\
\mathrm{I} .33\end{array}$ & 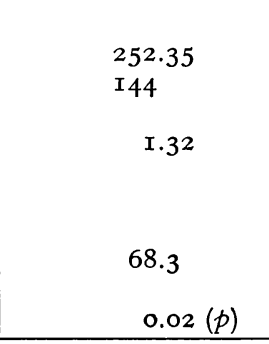 & 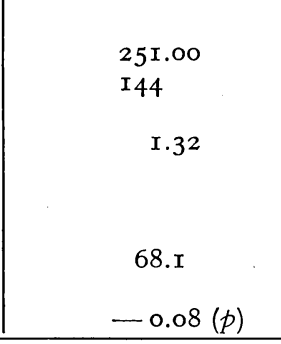 & 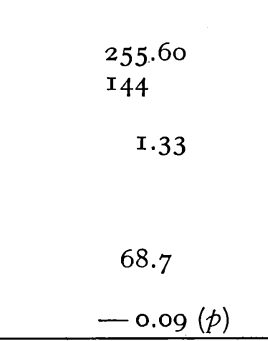 & $\begin{array}{l}25 \mathrm{I} .00 \\
\mathrm{I} 43 \\
\mathrm{I} .32 \\
\\
68.3 \\
-0.07(p)\end{array}$ & $\begin{aligned} & 68.7 \\
- & 0.59(p)\end{aligned}$ \\
\hline
\end{tabular}

${ }^{*} C V P_{1}=\frac{T_{v} \cdot \sqrt{N} \cdot G \cdot E}{T_{a} \cdot 360 \cdot \text { I00 }}$ 


\section{The relationship between some edaphic factors and forest yield}

In the preceding chapter it has been shown how the $C V P$-index and the individual composite climate factors excluding precipitation display impaired relationships with the growth potential when the variable changes from an expression of average yield within a certain area to an expression of the yield of a particular site. The reason is primarily to be found in the increased influence of edaphic factors.

To arrive at a practically useful index for the yield capacity of an individual site, it is therefore necessary to combine an expression of the one or the most important edaphic factors with an expression of climate. Some attempts to that affect will be made in the following presentation.

The dependence of plant growth on the moisture conditions of a site during various periods of the growing season has been discussed in a previous chapter. The need for continued and expanded research in this field thereby appeared very great. Knowing of the hygrometric conditions of the site, we may add that it will then be possible to cover part of the influence of topography by means of the influence of the site gradient on the movements of the soil water. Since the moisture retaining capacity of the site is related to the soil texture, the importance of the latter feature in this context would be considered in this way.

Attempts made in this investigation to find an expression of the site factor feasible to incorporate with our climate function have been tied to material already available and collected in conjunction with the lay-out of the experimental plots. Moreover, we have soil samples from the $C$-horizon, descriptions of the soil structure and notes describing whether the $B$-horizon rests directly on the bedrock.

\section{The electric conductivity of soil}

One method has been tested in particular to find a mathematical expression of the site factor. The method is based on the procedure used by D. R. HoAGLAND and J. S. BURD for the measurement of the electric conductivity of the site. Thus, an expression of the concentration of soluble nutrients available in the soil is obtained. The method has recently been used in Sweden by O. Arrhenius, who found a strong relationship between the conductivity and the forest yield as well as the crop of winter wheat (O. ARRHENIUS, I957, p. 322, f). These relationships have been stated on the basis of mean values from a very 
comprehensive material after the omission of all places with soil depth less than one meter ("either to the bedrock or to constant water surface have been omitted", ibid., p. 32I). Arrhenius further found that the top soil (corresponding to the $A+B$-horizons) has a conductivity considerably higher than that of the subsoil (approximately the $C$-horizon) - (ibid., I956, p. I0). The latter observation is of particular interest in this context since we have samples from the $C$-horizon only.

Conductivity has been determined in the soil laboratory of the Forest Research Institute. The values obtained are reported in column $S$, Table III, and expressed in the form of conductivity values defined by $\mathrm{IO}^{4} \times$ the specific conductivity (Kungl. Lantbruksstyrelsen, I950).

The introduction of conductivity $(S)$ as a special term in our regression functions (Tables 8 and 9) effects a slightly improved fit. In association with function No. 4 the dispersion of the function is reduced by 0.7 per cent. This function, however, does not show any statistical improvement of significance in relation to function No. 2 .

$C V P_{1}$ has not been tested in this context since it was developed in the final stage of this work. The statistical processing presented here was then completed. Since the relative importance of the conductive capacity for the relationship cannot be expected to display any great variation in combination with $C V P_{1}$, an investigation of this factor was not expected to produce a result justifying associated costs. Neither has an investigation of the influence of the stand composition on the relationship with $C V P_{1}$ for the same reason been found necessary.

Combined with the $C V P$-index, too, $S$ reduced the dispersion parameter by 2.I per cent to 75.6 per cent. The regression function is presented by function No. II.

$$
y=0.778+0.8 \mathrm{r} 6 S+0.0223 C V P
$$

The total correlation coefficient of $S$ is 0.43 (Table II) corresponding to a determination coefficient of 0.18 . The partial correlation coefficients seem to indicate certain relationships between $S$ and $T_{a}, G$ and $C V P$. It is remarkable that precipitation has no influence on $S$.

By means of two kinds of scatter graphs, one type with the CVP-index alone as an independent variable, the second type with $C V P \times S$ as an independent variable - the mean annual increment is the dependent variable in both cases-it has been possible to investigate the change of position of the individual points from one graph to the other. It appears that conductivity values below 0.5 effect an improved fit, conductivity values of 0.8 and above give an impaired fit, whereas intermediate values have no distinct influence. The observations may be interpreted to mean that a nutrient 
concentration for conductivity values below 0.5 is too low for the trees to exploit the climatic bioeffect of its site. Equilibrium between the latter property and the supply of nutrients occurs at conductivity values between 0.5 and 0.8 whereas the bioclimatic effect is insufficient for the forest to utilize the good nutrient status of the sites at still higher conductivity values. A final establishment of the correctness of these conclusions requires strengthened research efforts in this field. The importance will be of great practical value since the results will indicate avenues to follow toward an improvement of the yield conditions of the site in artificially established stands.

Investigations of the conductivity of the site provide some, though minute, explanations of the yield variations. However, it must be stressed that we have used values for the nutrient status obtained from the $C$-horizon, which is not entirely representative for the supply of nutrients in the root zone. Continued work along this line should primarily concentrate on investigations of the conductivity of the $B$-horizon, possibly also of the effect of the arithmetic mean value of $A-, B$-, and $C$-horizons on the relationships with the mean increment. The results obtained here as well as those originating from the investigations carried out by $\mathrm{O}$. Arrhenius provide strong indications that a further developed method can make conductivity a feasible and easily reproducible expression of the site factor; which may promise to give a satisfactory description of the productivity of the site in combination with the CVP-index.

\section{The influence of soil texture on the mean annual increment}

The influence of soil texture on the mean increment has been studied in a summary way by means of dispersion graphs with the $C V P$-index and the mean increment as variables. The soil texture has been classified for each sample plot according to the grain of the main fraction. When soil texture is noted for each point in the dispersion graphs, a certain tendency appears in the position of the various soils. The coarse-grained, relatively sorted soils, e.g. gravel and sand, are generally associated with low yield values. Loam with light inmixture of sand is mostly coupled with high yield values. Other soils in various mixtures are combined with yield of an average magnitude. Continued investigations should be aimed at finding an expression of the mean grain size per volume unit of soil within the $B$-horizon. The relationship between this expression and the hygrometric properties of the soil should be examined simultaneously by the application of formulas for the relationship between the soil texture and the water retaining capacity of the soil. It is probable that the expression of texture can be defined adequately by the hygrometric properties of the soil (cf. Holstener-Jørgensen, I958). 
The influence of soil depth, depth of the humus cover and horizons

Among the sample plots originally selected were some plots which subsequently were omitted since they differed markedly from the others. Since the environment of their sites displayed great differences only with respect to the depth of the soil, the latter factor must be considered as causing the deviations. It is a known fact that shallow soil generally means that the site is easily subject to drought as well as inferior yield conditions in general. An expressive proof is provided by J. Låg in his investigations of the relationship between soil depth and site quality. The relationships obtained are presented in the following tables (J. LÅG, I958, p. 7I, f).

Table I9. Relationships between soil depth and site quality in the forests of Telemark

\begin{tabular}{|c|c|c|c|c|c|c|}
\hline \multirow{2}{*}{$\begin{array}{c}\text { Total soil } \\
\text { depth }\end{array}$} & \multicolumn{5}{|c|}{ Frequency of plots by site classes, per cent } & \multirow{2}{*}{$\begin{array}{l}\text { Total no } \\
\text { plots }\end{array}$} \\
\hline & $I^{1}$ & 2 & 3 & 4 & 5 & \\
\hline $0-20 \mathrm{~cm}$ & - & 0.4 & I 7.5 & 47.I & 34.5 & $I, 986$ \\
\hline $20-70 \mathrm{~cm}$ & 0.8 & 6.1 & 40.1 & 38.6 & I 4.4 & 4,699 \\
\hline$>70 \mathrm{~cm} \ldots$ & 6.4 & 21.0 & 48.8 & I9.6 & 4.7 & 5,589 \\
\hline
\end{tabular}

Table 20. Relationship between soil type and site quality in the forests of Agder

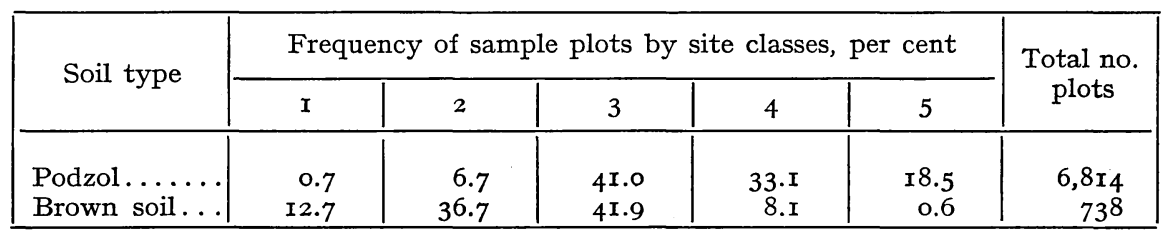

Table 2r. Relationship between humus layer and site class in the forests of Sør-Trøndelag

\begin{tabular}{|c|c|c|c|c|c|c|c|}
\hline \multirow{2}{*}{$\begin{array}{l}\text { Total soil } \\
\text { depth }\end{array}$} & \multirow{2}{*}{$\begin{array}{c}\text { Humus cover } \\
\mathrm{cm}\end{array}$} & \multicolumn{5}{|c|}{$\begin{array}{c}\text { Frequency of sample plots by site classes } \\
\text { per cent }\end{array}$} & \multirow{2}{*}{$\begin{array}{c}\text { Total no. } \\
\text { plots }\end{array}$} \\
\hline & & I & 2 & 3 & 4 & 5 & \\
\hline \multirow[t]{3}{*}{$0-20 \mathrm{~cm}$} & $0-3$ & I.O & I0.2 & 39.8 & 26.5 & 22.5 & 98 \\
\hline & 3 -10 & - & 2.1 & 20.8 & 43.8 & 33.3 & 384 \\
\hline & $>$ IO & - & 0.7 & I 3.4 & 40.8 & $45 \cdot \mathrm{I}$ & $I_{42}$ \\
\hline \multirow[t]{3}{*}{$20-70 \mathrm{~cm}$} & $0-3$ & 4.0 & 24.2 & 49.9 & I $7 \cdot 3$ & 4.6 & 7 II \\
\hline & 3 -10 & O.I & 5.I & $44 . I$ & 36.3 & $\mathrm{x} 4.4$ & I 5 I9 \\
\hline & $>$ ro & o.I & I. 2 & $25 \cdot 3$ & $47 \cdot x$ & 26.3 & 724 \\
\hline \multirow{4}{*}{$\begin{array}{l}\text { exceeding } \\
70 \mathrm{~cm} .\end{array}$} & & & & & & & \\
\hline & $0-3$ & $7 \cdot 5$ & 24.9 & 37.1 & I7.6 & 12.9 & I I 85 \\
\hline & 3 -10 & I.O & 9.4 & 48.9 & 26.6 & I4.I & 849 \\
\hline & $>$ I0 & 0.2 & 3.4 & 36.1 & 39.5 & 20.8 & 499 \\
\hline
\end{tabular}

1 Site class I indicates a mean annual increment exceeding $6.8 \mathrm{cu} . \mathrm{m}$ per hectare whereas site class 5 corresponds to a mean annual increment of $1.2-1.9 \mathrm{cu} . \mathrm{m}$ per hectare. 
The tables show clearly a concentration of plots with low site classes to the shallow soils (Table I9) and to sites with heavy humus cover (Table 2I). The high productivity of the brown soils in relation to that of the podzols is also clear (Table 20). It must be stressed, however, that differences are not exclusively caused by soil depth, humus cover and soil type but also by other factors such as climate, altitude, slope etc. In spite of the latter factors, soil depth has a great influence on yield and it should therefore be determined for depths less than one meter at each site examination. In this respect, too, it should be investigated in the future whether soil depth is reflected by the hygrometric properties of the soil. 


\section{The potential productivity of Norden's forests}

The relationships previously shown to exist between climate and to some extent the edaphic conditions on one side and the forest yield on the other have been possible to express in two different forms or functions. One function presents yield directly in figures on the basis of the individual contribution of the participating terms. With the knowledge of the magnitude of the participating terms of a site, it is thus possible to compute the potential yield. The second procedure involves relating yield to a complex climate factor, the CVP and $C V P_{1}$ index, respectively. Among the functions established and tested, three functions emerge as being superior. In function No. I4, Table I7, where the electric conductivity of the soil and the species mixture have been considered, a minimum standard deviation of the function amounting to 70,3 per cent of that of the total mean value has been obtained. If the species mixture and the electric conductivity are disconsidered, corresponding parameter amounts to 74.0 per cent in function No. 4, Table 8 and for CVP 77.7 per cent (function No. 7, Table 8) and for $C V P_{1} 7$ I. 8 per cent (function No. 6 Table I8). It should be stressed, however, that the value of $C V P_{1}$ is not fully comparable with the two others since it is based on a different selection from the material.

The multiple regression functions each give a yield value, the $C V P$ and $C V P_{1}$ index, respectively, which reflects the climatic conditions and associated changes. Presenting a value of the climatic bioeffect expressed in figures, our index therefore provides great advantages methodically. The regional occurence of the climatic bioeffect may be studied by means of climatoisophytes entered on a map according to a method developed previously by the author (ST. ST. Paterson, I956, p. I2I). Since the climatic bioeffect must be considered to vary with species from a hypothetical point of view, the index enables a simplified study of such variations as well as a presentation of a regional productivity relief map valid for each species (ibid., I959, p. I60). A simplified map of this kind without intensity shading of the various phyochores is presented in the map enclosed, Fig. 3I, which shows two different systems of climato-isophytes. One of the systems pertains to CVP and a choice of iso-lines based on function No. I8, where the admixture of Scots pine is considered. The second system refers to $C V P_{1}$ and its function No. 6, Table I8, in which the influence of species mixture is disconsidered. Comparative numbers of both the systems are shown in Table 22.

After application of the author's method of I956 (ibid., I956, p. I23 f.), half the interval between the index values above is added to or subtracted 


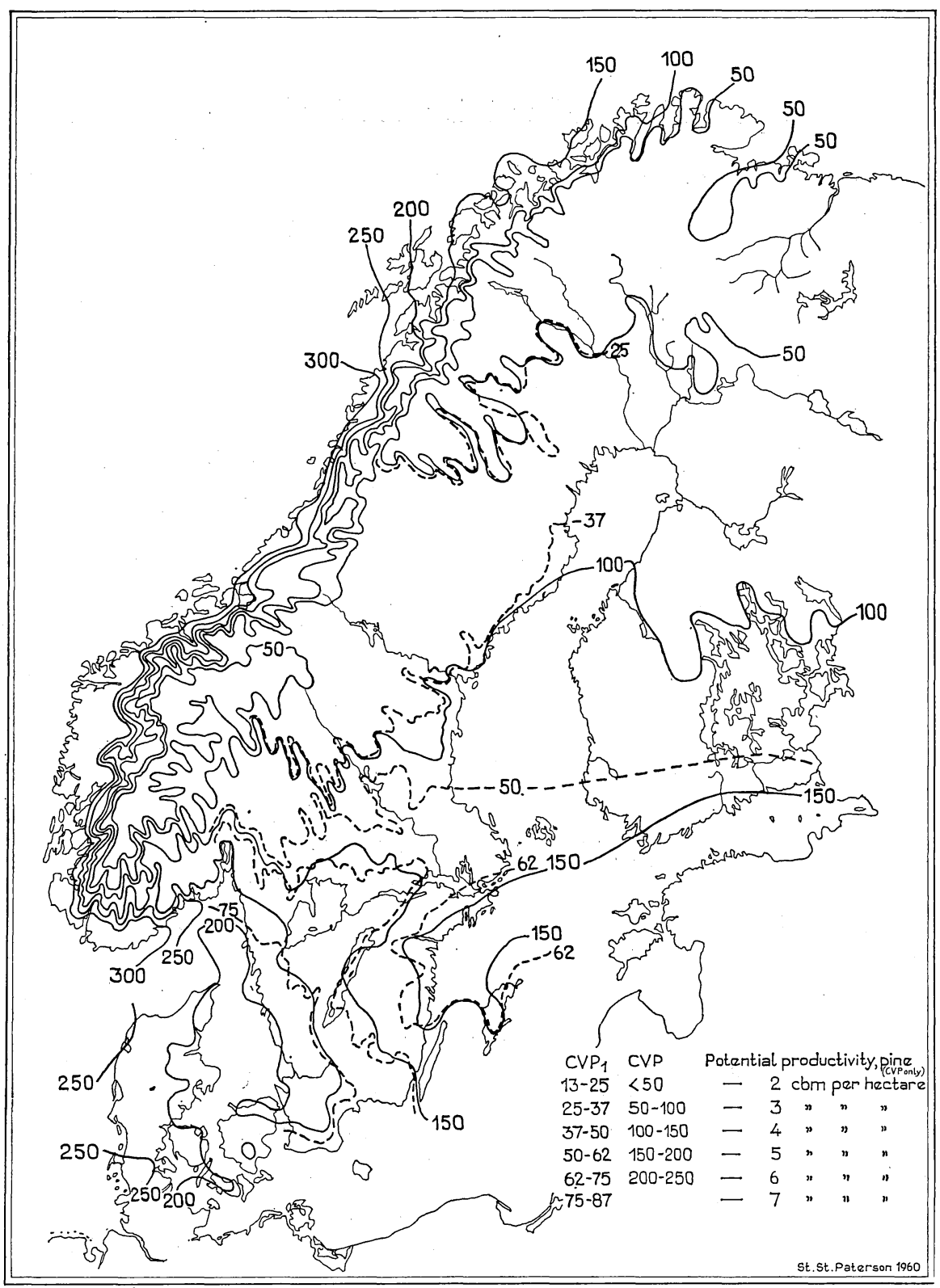

Figure 3r. Regional relief map of productivity. 
Table 22. The potential yield of pure Scots pine stands and Scots pine stands with light admixture of Norway spruce and deciduous species, and the $C V P$ and $C V P_{1}$ values corresponding to these yield values

\begin{tabular}{|c|c|c|}
\hline $\begin{array}{c}\text { Potential yield } \\
\text { cu.m/ha }\end{array}$ & $\begin{array}{c}\text { Scots pine stands } \\
C V P\end{array}$ & $\begin{array}{c}\text { Stands with } \\
\text { admixture of Scots } \\
\text { pine, CVP }\end{array}$ \\
\hline & & \\
I & - & 0.68 \\
2 & 27 & I.9I \\
3 & 77 & 3.14 \\
4 & $\mathrm{I27}$ & 4.37 \\
5 & $\mathrm{I} 77$ & 5.60 \\
6 & 227 & 6.83 \\
7 & 277 & 8.06 \\
8 & 327 & 9.29 \\
\hline
\end{tabular}

from each index value. Values so derived represent the limit values of a productivity, the mean value of which corresponds to the figures presented in the table above. The limit values correspond to the climato-isophytes sought, which, entered on the map, will delineate a number of phyochores. The method now requires a determination of the forest land area situated within each phyochor. The total potential yield is easily obtained if this area is multiplied by the mean yield of the phyochor concerned.

Being the function most suitable for this purpose, function No. 6, Table I8, was finally chosen as a basis for the computation of the potential productivity of the Nordic countries conducted here. The following table has been established.

Table 23. Relationship between potential productivity and median $C V P_{1}$ index value

\begin{tabular}{|c|c|c|}
\hline Range & $\begin{array}{c}C V P_{1} \text { index } \times \text { Io } \\
\text { centre }\end{array}$ & $\begin{array}{c}\text { Potential productiv- } \\
\text { ity cu. m/ha }\end{array}$ \\
\hline o-I3 & 6.8 & I \\
I3-25 & I9.I & 2 \\
$25-37$ & 3 I.4 & 3 \\
$37-50$ & 43.7 & 4 \\
$50-62$ & 56.0 & 5 \\
$62-75$ & 68.3 & 6 \\
$75-87$ & 80.6 & 7 \\
\hline
\end{tabular}

Particular difficulties affect the determination of the forest land area within the individual phyochores which do not generally follow statistically reported divisions. For the purpose of statistics concerning area, access is required to accurate, detailed information regarding the distribution of forest land on each side of a bordering climato-isophyte. In the present case the forest land area within our phyochores could be ascertained by means of material 
available in the department of forest survey at the Forest Research Institute of Sweden. This material has been compiled as a basis for "Atlas of Sweden" and its presentation of forest land according to the method of absolute squares. Statistically reported areas entirely located within a phyochor could be directly determined with respect to area on the basis of this material. The areas situated on each side of the border line were computed by counting corresponding squares in the "Atlas of Sweden". This work was carried out by Mr. O. KRONESTEDT, forest technician, benevolently supervised by Mr. V. ARman, M.F. The area distribution obtained is reported in Table 24 .

Table 24. Area of productive forest land and mountainous conifer forests in sq. $\mathrm{km}$ distributed by phyochores within regions

\begin{tabular}{|c|c|c|c|c|c|c|c|c|c|c|}
\hline \multirow[b]{2}{*}{ Region } & \multicolumn{2}{|c|}{-25} & \multicolumn{2}{|c|}{$25-37$} & $37-50$ & $50-62$ & $62-75$ & $75+$ & \multicolumn{2}{|c|}{ Total } \\
\hline & $\begin{array}{c}\text { Forest } \\
\text { land }\end{array}$ & $\begin{array}{c}\text { Moun- } \\
\text { tain- } \\
\text { ous } \\
\text { coni- } \\
\text { fer } \\
\text { forest }\end{array}$ & $\begin{array}{c}\text { Forest } \\
\text { land }\end{array}$ & $\begin{array}{c}\text { Moun- } \\
\text { tain- } \\
\text { ous } \\
\text { coni- } \\
\text { fer } \\
\text { forest }\end{array}$ & & Fores & $t$ land & & $\begin{array}{l}\text { Forest } \\
\text { land }\end{array}$ & $\begin{array}{c}\text { Moun- } \\
\text { tain- } \\
\text { ous } \\
\text { coni- } \\
\text { fer } \\
\text { forest }\end{array}$ \\
\hline $\begin{array}{l}\mathrm{I} \ldots \\
\mathrm{II}+\mathrm{I} \\
\mathrm{IV}+\end{array}$ & $\begin{array}{c}\text { I3, I } 75 \\
-\end{array}$ & $\begin{array}{l}4,075 \\
-\end{array}$ & $\begin{array}{c}52,466 \\
48,521 \\
-\end{array}$ & $\begin{array}{r}488 \\
3,080 \\
-\end{array}$ & $\begin{array}{r}2,850 \\
22,700 \\
4,942\end{array}$ & $\begin{array}{c}- \\
8,450 \\
30,410\end{array}$ & $\overline{2}_{29,853}$ & - & $\begin{array}{l}68,491 \\
79,671 \\
75,295\end{array}$ & $\begin{array}{l}4,563 \\
3,080 \\
-\end{array}$ \\
\hline $\mathrm{I}-\mathrm{V}$ & $\mathrm{I} 3, \mathrm{I} 75$ & 4,075 & 100987 & 3,568 & 30,492 & 38,860 & 29,853 & 10,090 & 223457 & 7,643 \\
\hline
\end{tabular}

The corresponding area distribution by phyochores in Denmark, Finland and Norway has been compiled by considerably simplified methods, which entailed larger generalization. As a basis the author has utilized his map of the forest area of the world (I956), which was compiled according to the method of absolute squares by entering the climato-isophytes of current interest. This method may be considered to provide satisfactory estimates for Denmark and Finland where the climato-isophytes are located far apart. The distribution of the Norwegian forest land area, however, is less accurately determined. The heavily cut-up topography of this country effects rapid, vertical changes of the phyochores which will thus be very narrow. A determination of the distribution of the forest land area with greater accuracy on the basis of these narrow phyochores would require maps with a large scale providing an abundance of details corresponding to that of the topographic map. This tedious procedure is considered beyond the object of this chapter which is to give a broad presentation.

The lack of meteorological stations and the generalization enforced by the map scale (Fig. 3I) will mean that mountainuos conifer forests are also found within the phyochores $25-37$ in Table 24 . It is known, however, that their 
geographic location is associated with the occurrence of mountainous areas. Placing the montainous, coniferous forests within the phyocohores o-I3 and on the basis of this experience, we obtain the following picture (Table 25) of the potential yield conditions within the main forest regions of Sweden (cf. map, Fig. 32).

Table 25. The potential productivity of the Swedish forest land area distributed by regions and phyochores

\begin{tabular}{|c|c|c|c|c|c|c|c|}
\hline \multirow{2}{*}{ Region } & \multicolumn{7}{|c|}{ Phyochor } \\
\hline & $0-x_{3}$ & I $3-25$ & $25-37$ & $37-50$ & $50-62$ & $62-75$ & $75+$ \\
\hline & \multicolumn{7}{|c|}{ cu. $m$ per hectare } \\
\hline & I & 2 & 3 & 4 & 5 & 6 & 7 \\
\hline I mill ha.............. & 0.46 & 1.32 & 5.25 & 0.29 & - & - & - \\
\hline$\| \quad$ cu. m............ & 0.46 & 2.64 & I 5.75 & I.I6 & - & - & - \\
\hline II/III mill ha $\ldots \ldots \ldots \ldots \ldots$ & $0.3 I$ & - & 4.85 & 2.27 & 0.85 & - & - \\
\hline 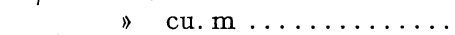 & $0.3 \mathrm{I}$ & - & $\mathrm{I} 4.55$ & 9.08 & 4.25 & - & - \\
\hline IV $/ V$ mill. ha $\ldots \ldots \ldots \ldots \ldots$ & - & - & - & 0.49 & 3.04 & 2.99 & I.OI \\
\hline$\gg$ cu.m........... & - & - & - & I.96 & $\mathrm{I} 5.20$ & I 7.94 & 7.07 \\
\hline Total, mill ha............. & 0.77 & 1.32 & IO.IO & 3.05 & 3.89 & 2.99 & I.OI \\
\hline 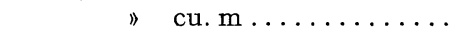 & 0.77 & 2.64 & 30.30 & $\mathrm{I} 2.20$ & I9.45 & I 7.94 & 7.07 \\
\hline
\end{tabular}

Figure 32. Regional division used by The National Forest Survey in Sweden.

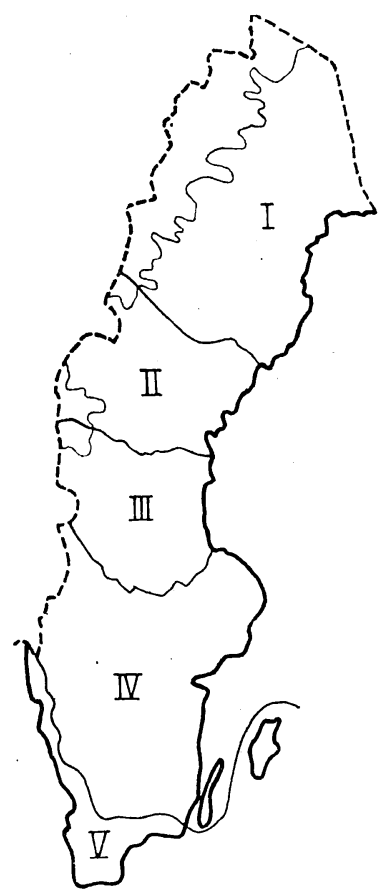


If the country is divided into a northern and a southern part and including as usual the regions IV and $\mathrm{V}$ in the latter part, area and potential yield are distributed as follows.

$$
\begin{array}{r}
\text { Area, mill. ha } \begin{array}{c}
\text { Potential yield, } \\
\text { mill. cu. m. }
\end{array}
\end{array}
$$

Northern Sweden............... I5.60

Southern $"$. ............ 7.53

The whole of Sweden ............ 23.13

It appears from the summary above that slightly less than a third of the national forest area is located in the southern part of Sweden. This minor part simultaneously represents 47 per cent of the total potential productivity. A division of the country into two equal halves would mean that the southern part would contain about two thirds of the total potential yield.

It may be interesting to compare the values for potential yield now presented with the mean annual increment at normal age class distribution according to the national forest survey.

According to Table 26 the mean annual increment at normal age class distribution in the Swedish forests would amount to 65.28 mill. cu.m. Of these 32.57 mill. cu.m. would be found in the northern part and 32.7 I mill. cu.m. in the southern part, i.e. 50 per cent in each.

The annual increment has been computed with a high degree of accuracy on the basis of systematic sampling. It represents the increment at the current status of forest resources.

The potential productivity has been obtained on the basis of yield recorded in sample plots in fully stocked, virgin stands. Particularly on the high grounds of northern Sweden, these stands must be considered as examples of yield attainable under not too unfavourable conditions. Experience has shown that calamities of various kinds, e.g. attacks of fungi and insects and seedling mortality directly associated with the severe climate often cause open stands in practice. These circumstances mean that many yield values obtained from sample plots in northern Sweden are probably higher than can normally be expected in this geographic region.

According to the national forest survey, increment is equally distributed by northern and southern Sweden. Provided this distribution is accepted, the calculated potential yield of Sweden would be reduced from 48.20 mill. cu.m. to $42 . \mathrm{I} 7$ mill. cu.m., or by $\mathrm{I} 2.5$ per cent and thus the total national potential yield would be established at 84 mill. cu.m. Corresponding adjustment should also be made with respect to Norway and Finland. 
Table 26. Mean annual increment. All species. Forest-land and range land*.

\begin{tabular}{|c|c|c|c|c|c|c|c|c|c|c|c|c|c|c|}
\hline \multirow{2}{*}{ Region } & \multirow[b]{3}{*}{$\begin{array}{l}\text { Increment, cu. m./ha.. } \\
\text { Area distribution, } \\
\text { current, per cent ... } \\
\text { normal, per cent .... } \\
\text { (rotation period } 135+ \\
5 \text { years) }\end{array}$} & \multicolumn{9}{|c|}{ Age class } & \multirow{2}{*}{$\begin{array}{l}\% \\
\text { per } \\
\text { cent }\end{array}$} & \multirow{2}{*}{$\begin{array}{l}\text { Mean } \\
\text { incre- } \\
\text { ment } \\
\text { per } \\
\text { hectare }\end{array}$} & \multirow{2}{*}{$\begin{array}{c}\text { Area } \\
\text { sq. km. }\end{array}$} & \multirow{2}{*}{$\begin{array}{l}\text { Total } \\
\text { yield } \\
\text { capacity } \\
\text { I,ooo } \\
\text { cu. m. }\end{array}$} \\
\hline & & o & I & II & III & IV & $\mathrm{V}$ & VI & $\begin{array}{l}\text { VII- } \\
\text { VIII }\end{array}$ & IX & & & & \\
\hline I & & $\begin{array}{c}0.230 \\
9 \\
4\end{array}$ & $\begin{array}{c}0.355 \\
4 \\
14\end{array}$ & $\begin{array}{c}\text { I.5I } 7 \\
9 \\
\text { I } 4\end{array}$ & $\begin{array}{c}\text { I.906 } \\
8 \\
\text { I } 4\end{array}$ & $\begin{array}{l}2.190 \\
\text { I } 3 \\
\text { I } 4\end{array}$ & $\begin{array}{c}2.30 \mathrm{I} \\
\mathrm{I} 7 \\
\mathrm{I} 4\end{array}$ & $\begin{array}{l}\text { I. } 848 \\
\text { I3 } \\
\text { I4 }\end{array}$ & $\begin{array}{l}\mathrm{I} .26 \mathrm{I} \\
\mathrm{I} 4 \\
\mathrm{I} 2\end{array}$ & $\begin{array}{c}0.90 \mathrm{I} \\
\mathrm{I3} \\
\end{array}$ & $\begin{array}{l}\text { IOO } \\
\text { IOO }\end{array}$ & $\begin{array}{l}\mathrm{I} .533 \\
\mathrm{I} .577\end{array}$ & 68,700 & $\begin{array}{l}\text { I0, } 530 \\
\text { Io, } 830\end{array}$ \\
\hline$I I+I I I$ & $\begin{array}{l}\text { Increment, cu. m./ha.. } \\
\text { Area distribution, } \\
\text { current, per cent ... } \\
\text { normal per cent .... } \\
\text { (rotation period I I } 5+ \\
5 \text { years) }\end{array}$ & $\begin{array}{c}0.403 \\
6 \\
4\end{array}$ & $\begin{array}{c}0.874 \\
4 \\
\mathrm{I} 7\end{array}$ & $\begin{array}{c}2.700 \\
\text { I0 } \\
\text { I } 7\end{array}$ & $\begin{array}{c}3.455 \\
\text { I3 } \\
\text { I7 }\end{array}$ & $\begin{array}{c}3.843 \\
20 \\
\text { I } 7\end{array}$ & $\begin{array}{c}3.6 \mathrm{I} 7 \\
\mathrm{I} 8 \\
\mathrm{I} 7\end{array}$ & $\begin{array}{l}2.992 \\
\text { I4 } \\
\text { II }\end{array}$ & $\begin{array}{l}2.304 \\
\text { I I } \\
-\end{array}$ & $\begin{array}{c}\text { I.467 } \\
4 \\
\end{array}$ & $\begin{array}{l}\text { roo } \\
\text { I0o }\end{array}$ & $\begin{array}{l}2.929 \\
2.809\end{array}$ & 77,400 & $\begin{array}{l}22,670 \\
21,740\end{array}$ \\
\hline $\mathrm{IV}+\mathrm{V}$ & $\begin{array}{l}\text { Increment, cu. m./ha } . \\
\text { Area distribution, } \\
\text { current, per cent } \ldots \\
\text { normal per cent } \ldots \\
\text { (rotation period } 90+5 \\
\text { years) }\end{array}$ & $\begin{array}{c}0.593 \\
5 \\
5\end{array}$ & $\begin{array}{c}\text { I. } 873 \\
9 \\
2 \mathrm{I}\end{array}$ & $\begin{array}{c}5 . \mathrm{I} 73 \\
20 \\
2 \mathrm{I}\end{array}$ & $\begin{array}{c}5 \cdot 547 \\
25 \\
2 \mathrm{I}\end{array}$ & $\begin{array}{l}5.257 \\
22 \\
2 \mathrm{I}\end{array}$ & $\begin{array}{c}4.527 \\
\text { I I } \\
\text { I I }\end{array}$ & $\begin{array}{c}3.893 \\
5 \\
-\end{array}$ & $\begin{array}{c}3.297 \\
2 \\
-\end{array}$ & $\begin{array}{c}2.36 \mathrm{I} \\
\mathrm{I} \\
-\end{array}$ & $\begin{array}{l}\text { IOO } \\
\text { IOO }\end{array}$ & $\begin{array}{l}4.544 \\
4.276\end{array}$ & 76,500 & $\begin{array}{l}34,760 \\
32,7 \text { 10 }\end{array}$ \\
\hline & & & & & & & $\begin{array}{l}\text { Acc. } \\
\text { Tot. } \\
\text { Acc. }\end{array}$ & $\begin{array}{l}\text { to cur } \\
\mathrm{I}-\mathrm{V} \\
\text { norma }\end{array}$ & $\begin{array}{l}\text { rent as } \\
\ldots \ldots \ldots \\
\text { a age }\end{array}$ & $\begin{array}{l}\text { distr } \\
\ldots \ldots \ldots \\
\text { istribu }\end{array}$ & $\begin{array}{c}\text { oution } \\
\ldots . . . \\
\text { on... }\end{array}$ & $\begin{array}{l}3.053 \\
2.934\end{array}$ & $\begin{array}{r}* * \\
222,600\end{array}$ & $\begin{array}{l}67,960 \\
65,280 \\
\end{array}$ \\
\hline
\end{tabular}

* The table has been compiled by Mr. V. ARMAN

** Mountainous forests not included. 
As a result of the preceding discussion, the regression lines previously presented will be situated too high in the graph within the range below approximately I25 CVP and $4.4 C V P_{1}$, respectively.

Summarized, the comparison made shows that the mean annual increment at normal age class distribution according to the material of the national forest survey amounts to 65 mill. cu.m., whereas the sample plots in virgin, fully stocked stands present a value of 84 mill. cu.m. for the climatically conditioned potential yield.

Based on $C V P_{1}$ a summary of the potential productivity of the Nordic forests is compiled in table 27 .

Table 27. The potential productivity of Norden

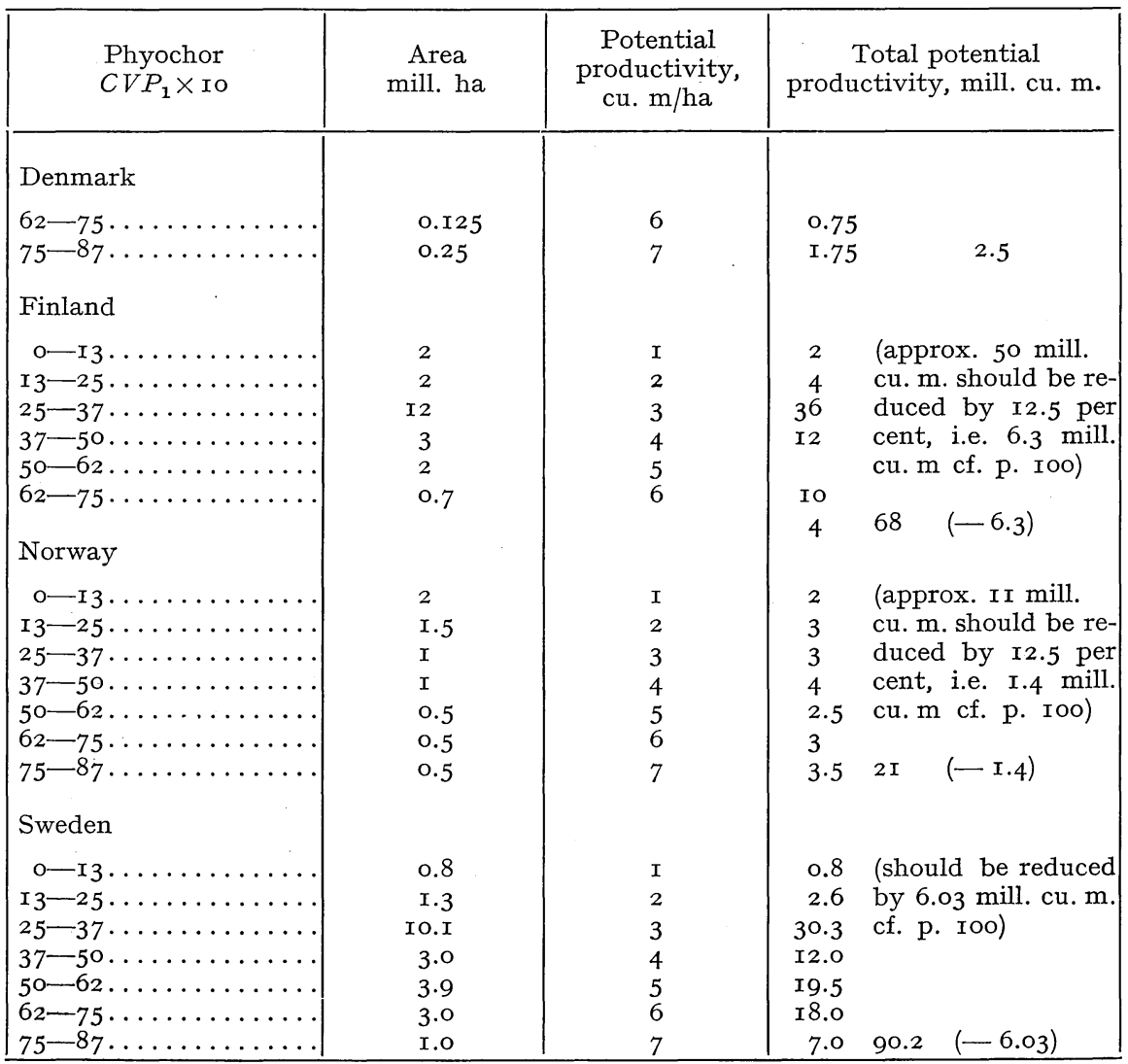


It may be of interest to compare the values obtained for the total potential productivity with the previous determination made by the author and with the official estimates of the mean annual increment and the annual depletion by felling operations. Excluding Denmark, the latter estimate is too low since timber removed for private consumption is not included.

Table 28. Comparison between estimated values of the potential productivity, mean annual increment and annual depletion

\begin{tabular}{|c|c|c|c|c|}
\hline \multirow{2}{*}{ Country } & \multicolumn{2}{|c|}{$\begin{array}{l}\text { Potential productivity } \\
\text { acc. St. St. Paterson }\end{array}$} & \multirow[t]{2}{*}{ Increment } & \multirow{2}{*}{$\begin{array}{l}\text { Depletion } \\
\text { I957-58 }\end{array}$} \\
\hline & I956 & I96I & & \\
\hline & \multicolumn{4}{|c|}{ mill. cu. $\mathrm{m}$} \\
\hline Denmark. . . & $(\mathrm{I} .8)$ & $(2.5)$ & 2 & 2 \\
\hline Finland $\ldots \ldots \ldots \ldots \ldots$ & $67 \cdot 5$ & 62 & .55 & $36^{1}$ \\
\hline Norway $\ldots \ldots \ldots \ldots \ldots \ldots$ & 27.5 & 20 & I6 & 9 \\
\hline Sweden ............... & 84.8 & 84 & 68 & $44^{2}$ \\
\hline
\end{tabular}

In the case of Denmark the figures concerning the potential productivity have been placed in brackets since they do not represent a forest natural to Denmark.

The relationship between increment and depletion, respectively, and the potential productivity according to $C V P_{1}$ provides an idea of the current degree of utilization of the climatically conditioned growth potential of the present forests. The highest degree of utilization is found in the case of Finland, where both increment and the potential productivity exceed depletion by 53 per cent and 72 per cent, respectively. Then follows Sweden where increment exceeds depletion by approximately 55 per cent while the potential productivity exceeds the latter by 90 per cent. Increment and the potential productivity in Norway exceed depletion by 78 per cent and I22 per cent respectively. In the latter country, however, reservations must be made due to the importance of the negative influence of precipitation.

\footnotetext{
1 mean value of the 1954 and 1957 estimates. 》 of the I954, I957, and I958 estimates.

Sources: F A O. Yearbook of Forest Products Statistics 1955 and 1959. HAGBERG, E. I959. Status of the Swedish Forests. Paterson, St. St., I956.
} 


\section{Summary}

Due to deficient material of observation the great importance of light as plant physiological factor cannot be considered at investigations of the relationships between climate and yield. The climate of light of the site, particularly at the upper part of the plant cover facing the atmosphere should be investigated by measurements of the solar radiation. A feasible instrument for this purpose is for example the Robitzsch automatic recording radiation meter (cf. Th. Wilhelmi I959, p. 205).

The volume increment produced at a certain site is a function of a strongly temperature dependent radial growth and a length and height growth probably governed by a climate factor varying for different species.

The relationship between light and heat must be studied by measurements on the site which may be expected to provide more accurate knowledge of the formation of assimilation products (radiation dependent) and the formation of wood (temperature dependent).

The length increment of tree roots is dependent on the soil temperature. Associated with the length growth of roots is the formation of root hairs, which are the most effective water absorbing organs of the trees. Strong relationships can therefore be assumed between the soil temperature and photosynthesis as well as transpiration. The soil temperature of the site should therefore be subject to continuous observations.

The author elucidates the unfeasibility of determining the length of the growing season by means of conditions prevailing at plant range boundaries or during some special vegetative development stage in the annual rhythm An expression describing some general, physiological condition is a better basis. The author finds that dry matter content and the relationship stated by O. LANGLET between the normal value of dry matter content and the no. days with a temperature exceeding $+6^{\circ} \mathrm{C}$ or $+8^{\circ} \mathrm{C}$ are expressions of this kind. Accordingly, and considering the views expressed by J. PARDÉ and A. F. Schimper, the author has chosen a temperature of $+7^{\circ} \mathrm{C}$ as the most suitable limit for a computation of the length of the growing season in forestry. The determination of this season is made by means of climate diagrams compiled by $\mathrm{H}$. WALTER.

Discussing the water as plant physiological factor, the author elucidates the great importance of an annual drought period. Such a period occurring, the thermally determined growing season is not a proper definition of the time factor. The ombro-thermal situation must also be considered as well as the 
hygro-thermal status. The water table and especially the capillary soil water have great importance for the growth potential by constituting a reserve during drought periods. Values particularly for the soil moisture of the root zone, the free water and their seasonal variations must be established 'by field observations. This provides a possibility of expressing the hygro-thermal growing season, which will be a more adapted component in a yield index for the site than the annual precipitation. Each species should be given a defined, hygro-thermal growing season of its own.

Since precipitation displays great local variations, the precipitation climate of the site should be determined by direct measurements. Adjustment for altitude must be made when interpolated temperature values are to be calculated for a sample plot or a precipitation station. Scrutinizing various correction factors, the author states some difference between the values computed by I. BRUun for Norway and those presented by WILD for Russia. The difference, however, is not of a magnitude justifying a denouncing of Wild's values for use in Sweden.

Studying the conditions of adjacent climate stations in Norway, the author has found that the reduction of the growing season at increasing altitude is presumably not linear but faster at a low level than the decline occurring at a high altitude zone (Table 5 ).

On the basis of J. WECK's discussion of the need for a judgement of the forest yield potential by means of the magnitude of the real assimilation, the author presents a summary of our present knowledge of the rates of assimilation, respiration and transpiration. The author finds that our knowledge of these important processes is still based on approximate values affected by methodical deficiencies. Data on photosynthesis and respiration now available therefore lack accuracy sufficient for their use in detailed phyochorological investigations. However, differences between various species can be established by comparative investigations of photosynthesis and respiration. Here, too, examples showing the necessity of treating each species separately are found. The transpiration, respiration and photosynthesis of the stand should be subject to strengthened research efforts.

With reservations made on account of the limited material, the statistical computations have shown that:

The $C V P$-value of the site is equally utilized in all the age classes invetigated here.

The volume increment of the trees increases with rising age in the age classes investigated.

The temperature amplitude is the climate factor covering most of the variation of the relationship between climate and yield in Sweden. Although showing nearly equal effect, the length of the growing season is strongly 
correlated with the temperature amplitude and more strongly than vice versa according to the partial correlation coefficients (Table II). Precipitation has a hardly noticeable influence. When other climate conditions are kept constant an increase in precipitation beyond a certain point effects reduced yield. A value of $600 \mathrm{~mm}$ seems to be the turning point.

The climate of the site must be subject to direct observations to provide accurate analyses of the yield factors by means of phyochorology.

The stand composition has an apparent influence on the magnitude of the mean increment.

Comparisons between the Swedish and the Norwegian material show the latter data to display a considerably lower yield potential, particularly at high index values. This may be explained by the reduction of yield caused by the leaching of soil nutrients on account of large amounts of precipitation and by the fact that Scots pine is a species less suited to sites of this type.

The electric conductivity of the soil in the $C$-horizon shows a weak influence on yield. An improved relationship may be obtained, however, if conductivity is measured in the $B$-horizon or if a mean value representing the $A-, B$ - and $C$-horizons is used. Certain observations made in this investigation may be interpreted to mean that nutrient concentrations indicated by conductivity values below 0.5 are too low for the forest to utilize the climatic bioeffect of the site while complete utilization occurs at conductivity values between 0.5 and o.8; at still higher conductivity values the forest is unable to utilize the favourable nutrient status of the soil. Continued research in this field is required to reach a final conclusion.

The influence of soil texture on the mean increment seems to have the following general tendencies: coarse, relatively sorted soils are associated with low yield values whereas loam with light inmixture of sand is coupled with high yield.

Investigations made in Norway show a clear correlation between i.a. soil depth and site quality to the effect that shallow sites show low quality. The soil depth should therefore be determined at site examinations at least for soil depths of less than one meter.

After a choice of suitable climato-isophytes, the $C V P$-, resp. $C V P_{1}$-index enables the establishment of regional relief maps showing productivity for each species. Such a map is presented in this report for Scots pine. The potential forest yield (potential productivity) is finally computed for the Nordic countries (Table 27) and compared with the annual values of increment and timber removed in felling observations (Table 28). 


\section{Sammanfattning \\ Nordens fyokorologiska grunddrag}

Fyokorologi är läran om den areella produktionens ekologi och geografiska spridningsbild. I denna undersökning är närmast sambandet mellan klimat och skoglig produktion föremål för bearbetning.

Förf. ger först en kort översikt över den skogliga fyokorologiens växtfysiologiska grunder. Här påtalas att ljusets betydelse ej kan beaktas vid en sambandsundersökning av ifrågavarande slag på grund av bristande observationsmaterial. Ståndortens ljus- och temperaturklimat måste bli föremål för närmare undersökningar, om säkrare kännedom skall vinnas rörande assimilatbildning (strålningsbunden) och träbildning (temperaturbetingad).

Ett starkt samband synes föreligga mellan marktemperaturen, som reglerar trädrötternas längdtillväxt, och fotosyntesen ävensom transpirationen. Ståndortens marktemperatur bör därför bli föremål för fortlöpande observation.

Olika tillvägagångssätt diskuteras rörande bestämning av vegetationsperiodens längd. På grundval av arbeten gjorda av O. Langlet, J. Pardé och A. F. Schimper finner förf. $+7^{\circ} \mathrm{C}$ vara den lämpligaste temperaturgränsen för beräkning av den skogliga vegetationsperiodens längd. Metodiskt utföres beräkningen med hjälp av H. Walters klimatdiagram.

Vid behandlingen av vattnet som växtfysiologisk faktor understryker förf. den stora betydelsen av förekomsten av en årlig torrtid. Uppträder en sådan blir den termiskt bestämda vegetationsperioden ej riktig ur växtfysiologisk synvinkel. Hänsyn bör tagas till såväl den ombrotermiska situationen som till den hygrotermiska. Grundvattnet och det kapillära markvattnet förs här in i bilden såsom varande av stor betydelse för växtkraften genom att tjänstgöra som reserv under torrtider. Värden på främst rotskiktets markfuktighet ävensom på grundvattennivån samt på dessa bådas säsongvariationer måste fastställas genom framtida fältundersökningar. Först härefter ges möjlighet till att finna ett uttryck för den hygro-termiska vegetationsperioden, vilken blir en mera rättvisande komponent i ett produktionsindex för ståndorten än vad årsnederbörden är. Varje trädslag bör givas sin egen definierade hygro-termiska vegetationsperiod.

Genom att studera förhållandena vid varann närbelägna klimatstationer i Norge finner förf. stöd för att vegetationsperiodens avtagande med stigande höjd ej sker lineärt utan med större hastighet på lägre nivå än på högre (tabell 5).

Vi sakna ännu tillräckliga data rörande fotosyntes och respiration för att dessa skall vara direkt användbara vid detaljerade fyokorologiska undersökningar.

Med reservation för materialets begränsning framgår ur den statistiska bearbetningen att:

Ståndortens $C V P$ utnyttjas lika i alla här berörda åldrar;

Volymökningen hos träden stiger med tilltagande ålder inom här berörda åldrar; Temperaturamplituden är den klimatfaktor, som i Sverige fångar upp mest av spridningen inom sambandet mellan klimat och produktion. Nära nog samma effekt visar vegetationsperiodens längd. Denna är emellertid starkt korrelerad med temperaturamplituden och starkare än motsatsen enligt vad som kan utläsas ur de partiella korrelationskoefficienterna (tab. II). 
Nederbörden har ett föga märkbart inflytande. En ökning av nederbörden vid i övrigt konstanta klimatförhållanden innebär sjunkande produktion. Vändpunkten härför synes ligga vid ca $600 \mathrm{~mm}: \mathrm{s}$ årsnederbörd.

Ståndortsklimatet måste bli föremål för direkta observationer för att man skall kunna nå fram till säkra analyser av produktionsfaktorerna genom fyokorologisk metod.

Beståndsblandningen har en tydlig inverkan på medeltillväxtens storlek.

Jämförelse mellan det svenska och norska materialet visar, att det senare vid framför allt högre indexvärden har en betydligt lägre produktionspotential. Förklaringen kan tänkas ligga i en genom höga nederbördsmängder orsakad urlakning av markens närsalter med åtföljande produktionsnedsättning, samt i att tallen är ett för dessa ståndorter mindre lämpligt trädslag.

Markens elektriska ledningsförmåga inom $C$-skiktet visar ett svagt samband med produktionen. Ett förbättrat samband kan dock förväntas uppkomma, om ledningsförmågan inom $B$-skiktet, eventuellt dess medelvärde för $A$-, $B$ - och $C$-skikten lägges till grund istället. Vissa nu gjorda iakttagelser kunna tolkas så, att en närsaltskoncentration på upp till ledningstalet 0,5 är för lågt för att skogen skall kunna utnyttja sin ståndorts klimatiska bioeffekt, ett fullt utnyttjande av den senare föreligger vid ledningstal mellan 0,5 och o,8, medan vid ännu högre ledningstal klimatets bioeffekt framstår som otillräcklig för att skogen skall kunna utnyttja markens goda näringstillstånd. Ett slutgiltigt bekräftande av dessa antaganden kräver fortsatta forskningar på området.

Jordartssammansättningens inflytande på medeltillväxten synes ha följande allmänna tendens: grovkorniga, relativt oblandade jordarter följas av låga produktionsvärden; som motsats härtill står mjäla med svag inblandning av sand med åtföljande höga produktionssiffror.

I Norge gjorda undersökningar visa en tydlig samvariation mellan bl. a. markdjup och bonitet på så sätt, att grund mark ger låga boniteter. Vid varje ståndortsundersökning bör därför markdjupet bestämmas på ned till minst en meters djup.

$C V P_{1}$-indexet - skiljer sig från $C V P$-indexet genom att nederbörden ingår med sitt rotvärde - möjliggör, efter lämpligt val av klimatoisofyter, upprättande av en för ett givet trädslag anpassad produktivitetsrelieflandskapskarta. Som avslutning beräknas den skogliga potentiella produktiviteten i de nordiska länderna (tab. 27) och jämföres med den årliga tillväxten och avverkningen (tab. 28). 


\section{Plates and figures}

Figure I. Solar radiation and weekly mean temperature of air in per cent of the

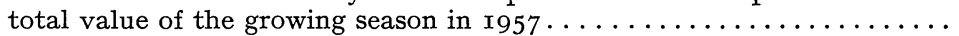

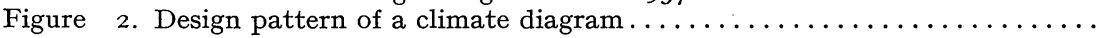

Figure 3. Climate diagram for Kystehospitalet, Denmark . . . . . . . . . . . .

Figure 4. Climate diagram for Askov, Denmark . . . . . . . . . . . . . .

Figure 5. Climatogram for Askov, Denmark, years I9I6-1925 ..........

Figure 6. Climate diagram for Hammershus, Denmark . . . . . . . . . . . .

Figure 7. Climatogram for Hammershus, Denmark, years I92 I and I923 ......

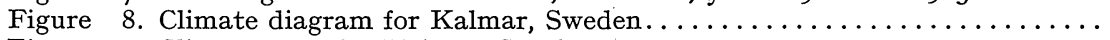

Figure 9. Climatogram for Kalmar, Sweden, years I9r6-1925 . . . . . . . .

Figure ı. Climatogram for Växjö, Sweden, years I9ı 6 I925 $\ldots \ldots \ldots \ldots \ldots \ldots$

Figure Ir. Climate diagram for Växjö, Sweden . . . . . . . . . . . . . . .

Figure I2. Climate diagram for Borås, Sweden $\ldots \ldots \ldots \ldots \ldots \ldots \ldots \ldots \ldots$

Figure 13 . Climatogram for Borås, Sweden, years I9I6-I925 ..........

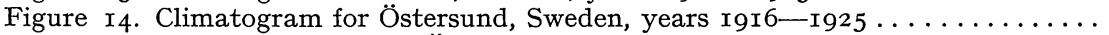

Figure I5. Climate diagram for Östersund, Sweden . . . . . . . . . . . . . . . .

Figure r6. Climate diagram for Bergen, Norway $\ldots \ldots \ldots \ldots \ldots \ldots \ldots \ldots \ldots \ldots$

Figure 17 . Climate diagram for Ulstad, Norway . . . . . . . . . . . . . . .

Figure 18. Map of the ombro-hygro-thermal regions of the Nordic countries.......

Figure 19. The location of the station lines in relation to anomalies ...........

Figure 20. Scatter graph showing the reduction of the growing season at increasing

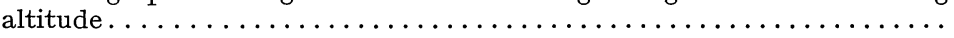

Figure 21. Scatter graph showing the relationship between $C V P$ and yield, age class

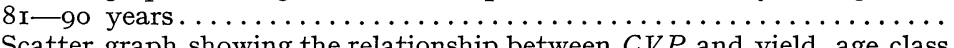

Figure 22. Scatter graph showing the relationship between $C V P$ and yield, age class

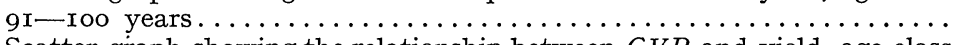

Figure 23. Scatter graph showing the relationship between $C V P$ and yield, age class

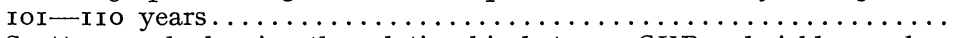

Figure 24. Scatter graph showing the relationship between $C V P$ and yield, age class III-I 20 years . . . . . . . . . . . . . . . . . . . . . .

Figure 25. Regression functions for each age class and for the total material....

Figure 26. Frequency of the sample plots by forest types in each age class, per cent

Figure 27. The theoretical regression line of the total material and the 95 per cent confidence belt.

Figure 28. Relationship between the yield and climate of the site in the Nordic countries. Comparisons between scatter graphs and regression functions.

Figure 29. Relationships between yield and $C V P$ for southern and northern Sweden,

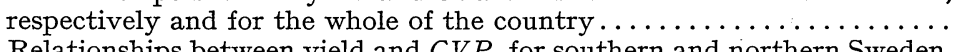

Figure 30 . Relationships between yield and $C V P_{1}$ for southern and northern Sweden, respectively, and for the whole of the country $\ldots \ldots \ldots \ldots \ldots \ldots$

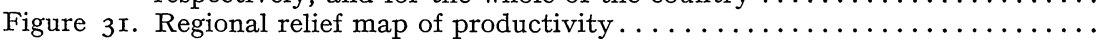

Figure 32. Regional division used by The National Forest Survey in Sweden.......

Plate I. The geographical location of the sample plots investigated..........

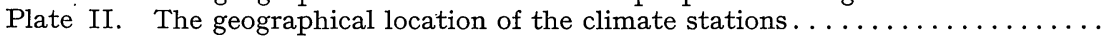

\section{Tables}

Table I. The correlation between radial growth, length growth and growth in cu. $\mathrm{m}$ of the pine in Utsjoki-Enare and the mean temperature at Sodankylä

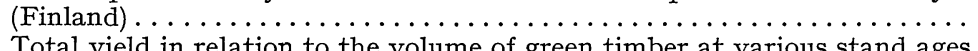

Table 2. Total yield in relation to the volume of green timber at various stand ages

Table 3. Decline of temperature at increasing altitude according to various authors

Table 4. Reduction of the growing season at increasing altitude for various stations

Table 5. Decrease in length of growing season at increasing altitude for various altitudinal zones, no. days . . . . . . . . . . . . . . . . . 
Table 6. Relative values of the apparent photosynthesis expressed in $\mathrm{kg} \mathrm{C}$ per hectare and annum for some species occurring in Germany ............

Table 7. Relative values of "Derbholzzuwachs" expressed in $\mathrm{kg} \mathrm{C}$ per hectare and annum for some species occurring in Germany.................

Table $\cdot 8$. Regression functions, yield potential adjusted for natural thinning (volume

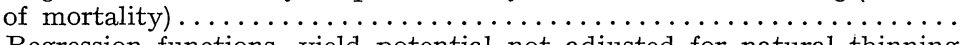

Table 9. Regression functions, yield potential not adjusted for natural thinning

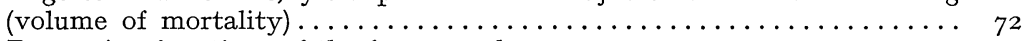

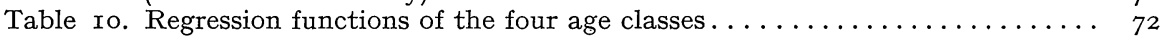

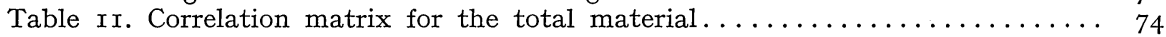

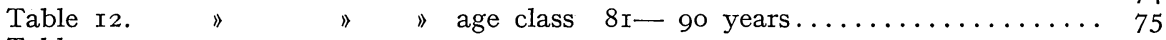

Table I3. " " " " $"$ "

Table I4. " " " $"$ IOI-IIO $" \ldots \ldots \ldots \ldots \ldots \ldots \ldots \ldots 75$

Table I5. " " " $"$ " III-I20

Table I6. Partial and total correlation coefficients of the relationships between certain climate elements and the yield values of the individual sites and

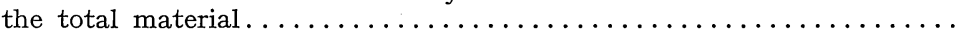

Table I7. Regression functions showing the influence of stand composition.......

Table $x$. Regression functions for the testing of possibilities for an improved relationship by entering radicals of certain terms used in the $C V P$ expression

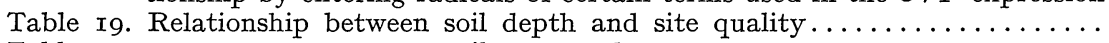

Table 20. " " soil type and " $" \ldots \ldots \ldots \ldots \ldots \ldots \ldots$

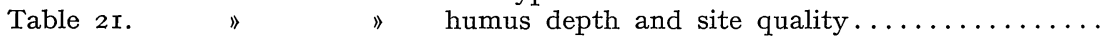

Table 22. The potential yield of pure Scots pine and Scots pine with admixture, and the $C V P$ and $C V P_{1}$ values corresponding to these yield values $\ldots \ldots \ldots$

Table 23. Relationship between the potential productivity and the median $C V P_{1^{-}}$

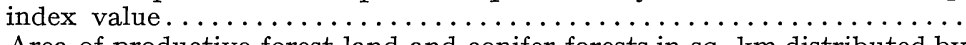

Table 24. Area of productive forest land and conifer forests in sq. $\mathrm{km}$ distributed by phyochores within regions. . . . . . . . . . . . . . . . . . . . .

Table 25. The potential productivity of the Swedish forest land area distributed by

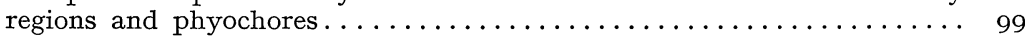

Table 26. Mean annual increment. All species, forest land and range land ....... IO

Table 27. The climatically conditioned potential productivity in Norden ........ IO2

Table 28. Comparisons between estimated values of the potential productivity and annual values of increment and timber volume removed in felling opera-

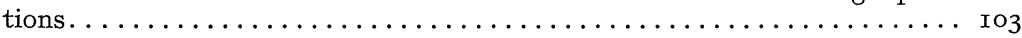

Table I. Yield data of the Swedish sample plots $\ldots \ldots \ldots \ldots \ldots \ldots \ldots \ldots \ldots \ldots \ldots \ldots$ Ir 5

Table II. Climatological data of the meteorological stations in the Nordic countries:

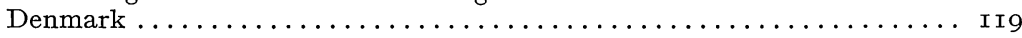

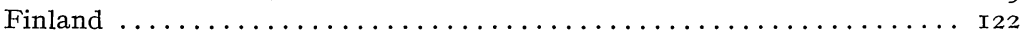

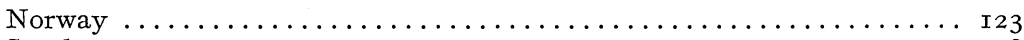

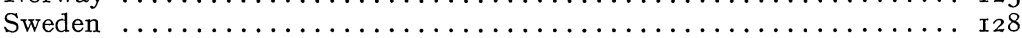

Table III. Yield, climate data and $C V P$-index of forest sample plots in the Nordic countries:

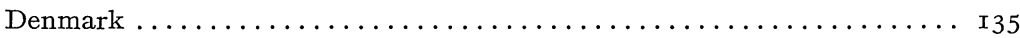

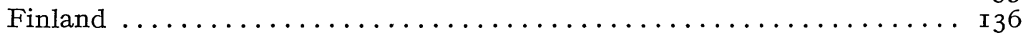

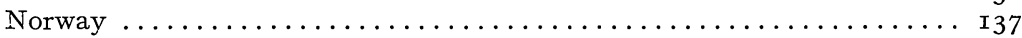

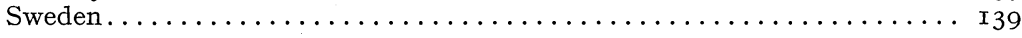

\section{Published sources of information and literature used}

ANDERsson, S.-O., I953, Om tidpunkten för den årliga diametertillväxtens avslutande hos tall och gran (On the date of completion of annual diametral growth in pine and spruce). Meddelanden frä Statens Skogsforskningsinstitut, Band 43, Nr 5, Stockholm.

ARrheniUs, O., I956. The corrosion of steel in soil. Tekniska Skrifter utg. av Svenska Teknologföreningen, $\mathrm{nr}$ I 59. Stockholm.

- I957 a, Plant-food from decayed leaves and conifer needles. Acta Agriculturae Scandinavica, VII: 4. Stockholm.

- I957 b, Kemisk denudation i fjällregionen. Geologiska Föreningens Förhandlingar 79: 4. Stockholm. 
Austin Miller, A., I953, Climatology. London.

Bagnouls, F. \& Gaussen, H., I953, Saison sèche et indice xérothermique. Documents Pour Les Cartes Des Productions Végétales, Tome III, Vol. I, Art. VIII. Toulouse..

Bratihe, P., I957, Thinnings in Even-Aged Stands. Faculty of Forestry, University of New Brunswick. Fredericton.

BRuUn, I., I957, se Det Norske Meteorologiske Institutt, r957.

CARbonnier, CH., I954, Några exempel på produktionen i planterad granskog i södra Sverige. Meddelanden frän Statens Skogsforskningsinstitut, Band 44, Nr 5. Stockholm.

- I957, Ett gallringsförsök i planterad granskog. Meddelanden frän Statens Skogsforskningsinstitut, Serien uppsatser $\mathrm{nr}$ 55. Also in Sv. Skogsvairdsfören. Tidskr. I957: 5 . Stockholm.

CARbonnier, Ch., I959, Gallringsförsök i naturbestånd av tall i Norrbottens län. Meddelanden frän Statens Skogsforskningsinstitut, serien uppsatser nr 67. Also in Sv. Skogsvårdsföreningens Tidskrift. I959: 3. Stockholm.

Det Danske Meteorologiske Institut. I933, Danmarks Klima, København.

Det Norske Meteorologiske Institutr, I949, Nederbøren i Norge I895-I943. Bind I-II. Oslo.

Det Norske Meteorologiske Institutt, I958, Lufttemperaturen i Norge I86I-I955. Bind I-II. Oslo.

EkLUND, B., I954. Årsringsbreddens klimatiskt betingade variation hos tall och gran inom norra Sverige åren I900-I944. (Variation in the Widths of the Annual Rings in Pine and Spruce due to Climate Conditions in Northern Sweden during the Years I9ooI944). Meddelanden frain Statens Skogsforskningsinstitut, Band 44, $\mathrm{Nr} 8$. Stockholm.

- I957, Om granens årsringsvariationer inom mellersta Norrland och deras samband med klimatet. Meddelanden frän Statens Skogsforskningsinstitut, Band 47, $\mathrm{Nr} \mathrm{I}$. Stockholm.

EMberger, L., I955, Une classification biogéographique des climats. Recueil des Travaux des Laboratoires de Botanique, Géologie et Zoologie de la Faculté des Sciences de l'Université de Montpellier. Montpellier.

FABER, F. C., I935, see Schimper, A. F. I898.

Fairbairn, W. A., \& M. L. Anderson, I955, Division of Scotland into Climatic SubRegions as an aid to Silviculture. Bulletin of the Forestry Department University of Edinburgh, Scotland. No. I. I955.

Filzer, P., I95I, Die natürlichen Grundlagen des Pflanzenertrages in Mitteleuropa. Stuttgart.

Food AND Agriculture Organization, 1955 and I959, Yearbook of Forest Products Statistics. Rome.

Food And Agriculture Organization, I958, The Growth of Forest Industries And Their Impact On The World's Forests. Reprinted from "The State of Food and Agriculture I958". Roma.

Freeland, R. O., I944, Apparent photosynthesis in some conifers during winter. Plant Physiology, Vol. I9 No 2.

Gaussen, H., see Bagnouls, F. \& Gaussen, H. I953.

Hagberg, E., I959, Tillståndet i Sveriges skogar. Sv. Skogsvårdsfören. Tidskr. I959: 2. Norrtälje.

HAMBERG, H. E., I909, Molnighet och solsken på den skandinaviska halvön (Nébulosité et soleil dans la Péninsule Scandinave). Bihang till Meteorologiska Iakttagelser $i$ Sverige. Vol. 50. I908. Uppsala.

- I9r4, Storleken av temperaturens dagliga variation på den skandinaviska halvön (Grandeur de la variation diurne de la temperature dans la péninsule Scandinave). Bihang till Meteorologiska Iakttagelser $i$ Sverige. Vol. 54. r9r2. Uppsala.

- I922, Termosynkroner och termoisokroner på den skandinaviska halvön (Thermosynchrones et thermoisochrones dans la péninsule scandinave). Bihang till Meteorologiska iakttagelser $i$ Sverige. Vol. 6o. 1918. Uppsala.

HolmsGaARD, E., I955, Årringsanalyser af danske skovtrær (Tree-Ring Analyses of Danish Forest Trees). Det Forstlige Forsøgsveesen $i$ Danmark. Bd. XXII, Hft I. København.

Holstener-Jørgensen, H., r955, Vattnets Bevægelse i Jorden. Dansk Skovforenings Tidskrift, Bind XL. København.

- I956, Nedbøren og grundvandet. Dansk Skovforenings Tidskrift, Bind XLI. København. 
Hustich, I., I948, The Scotch pine in northernmost Finland and its dependence on the climate in the last decades. Acta Botanica Fennica 42. Helsinki.

HyGEN, G., Kullsyreassimilasjon og kvanteteori. Naturen. Bergen og København.

INSTRUKTION FÖR AVFATTNING AV VÄDERLEKSTELEGRAM, I94O, Statens MeteorologiskHydrografiska Anstalt, Stockholm.

IwanOFF, L., 1924, Über die Transpiration der Holzgewächse im Winter. Bevichte Dev Deutschen Botanischen Gesellschaft. Band XLII.

Kмосн, K. \& Schulze, A., I954, Methoden der Klimaklassifikation. Bad Kissingen.

KUNGL. LANTBRUKSSTYRELSENS KUNGÖRELSER m. m. I95o Nr 8. Stockholm.

KÜChler, A. W., I957, Sten Sture Paterson: The Forest Area of The World and Its Potential Productivity. Economic Geography, Vol. 33 No 2. Worcester, Mass.

LADEFoGED, K., I939, Untersuchungen über die Periodizität im Ausbruch und Längenwachstum der Wurzeln bei einigen unseren gewöhnlichsten Waldbäume. Det Forstlige Forsøgsvesen $i$ Danmark. København.

- I956, Undersøgelser over Træernes Vandforbrug. Dansk Skovforenings Tidskrift, Bind XLI. København.

LANGLET, O., I935, Till frågan om sambandet mellan temperatur och växtgränser (Über den Zusammenhang zwischen Temperatur und Verbreitungsgrenzen von Pflanzen). Meddelanden från Statens Skogsförsöksanstalt, hf. 28, N:r 3. Stockholm.

- r936, Studier över tallens fysiologiska variabilitet och dess samband med klimatet. Ett bidrag till kännedomen om tallens ekotyper. (Studien über die physiologische Variabilität der Kiefer und deren Zusammenhang mit dem Klima. Beiträge zur Kenntnis der Ökotypen von Pinus Silvestris L.). Meddelanden från Statens Skogsförsöksanstalt, hf. 29, N:r 4. Stockholm.

LAUER, W., I952, Humide und aride Jahreszeiten in Afrika und Südamerika und ihre Beziehung zu den Vegetationsgürteln. Bonner Geographische Abhandlungen, Heft 9. Bonn.

Lauscher, F., I958, Der CVP-Index, ein Versuch der Klassifikation der Erdklimate auf Grund der forstlichen Produktivität. Wetter und Leben, Jahrg. I2, Hf. 5-6. Wien.

Lieth, H., see Walter, H. \& Lieth, H.

LÅG, J., I958, Noen refleksjoner omkring begrepet bonitet. Norsk Tidskrift for Jordskifte og Landmålning, $\mathrm{nr} \mathrm{I}-2$, 1958.

Malmström, C., I949, Studier över skogstyper och trädslagsfördelning inom Västerbottens län. Meddelanden frän Statens Skogsforskningsinstitut, Band 37, $\mathrm{Nr}$ Ir. Stockholm.

- I949, Om betydelsen av hänsynstagande till skogstypen inom skogsskötseln. (The forest type and its importance in silviculture). Kungl. Lantbruksakademiens Tidskrift Årg. 88 .

Matérn, B., se Tamm, O. F. S. I959.

Meteorologiska Centralanstalten, i956, Månadsöversikt av väderleken i Finland. N:ris I-I2, Årgång 50. Helsinki.

Meteorologiska iAktTAGelser I SVerige I9I4-I9I8, Vol. 56-6o. Meteorologiska Centralanstalten. Stockholm.

Meteorologiska iAkTtagelser I Sverige ÅREN I9I9-I925. Sveriges Meteorologiska och Hydrologiska Institut, Årsbok, Del IV. Stockholm.

Mitscherlich, E. A., r933, Der Einfluss klimatischer Faktoren auf die Höhe des Pflanzenertrages. Halle.

MøLler, C. M., 1956, Nedbøren og grundvandet. Dansk Skovforenings Tidskrift, Bind XLI. København.

Mork, E., I94I, Om sambandet mellom temperaturen og vekst (Über den Zusammenhang zwischen Temperatur und Wachstum). Meddelelser fra Det Norske Skogsforsøksvesen, $\mathrm{Nr}$ 27. (Bind VIII, Hefte I). Oslo.

Mork, E., I960, Om sambandet mellom temperatur, toppskuddtillvekst og årringens vekst och forvedning hos gran. (Picea abies (L.) Karst.) (On the relationship between temperature, leading shoot increment and the growth and lignification of the annual ring in Norway spruce). Meddelelser fra det Norske Skogsforsøksvesen,Sv. Nr 56 (Bind XVI: 4). Vollebekk.

Noser, M., I958, Vlhkost ovzduší na Moravě a ve Slezsku. (Die Luftfeuchtigkeitsverhältnisse in Mähren und Schlesien (ČSR)). Spisy Vydávané Prírodovédeckou Facultou Masarykovy University, I958/10. Brno. 
OksBJerg, E., I956, Nedbøren og grundvandet. Dansk Skovforenings Tidskrift, Bind XLI. København.

PARDÉ, J., 1958, Une Notion Nouvelle Et Fructueuse: L’Indice C. V. P. Revue Forestière Française No 3, mars 1958 .

PARDÉ, J., I959 a, Retour sur l'Indice C. V. P. de Paterson. Revue Forestière Française No I, Janvier I959.

- I959 b, Production ligneuse et indice de Paterson. Journal Forestier Suisse No 4, Avril I959.

Paterson, St. St., I956, The Forest Area of the World and its Potential Productivity. Diss. Göteborg.

- I957, Några centrala skogliga begrepp i globala sammanhang. Sv. Skogsvårdsfören. Tidskr., hf. 4. Norrtälje.

- I958, Fyokorologiskt bidrag till kännedomen om några grundfaktorer för Sveriges skogliga produktivitet. Festskrift till Olof Jonassons 65-airsdag. Göteborg.

- I959, Förslag till bioklimatisk regionindelning av Norden (A Scheme for a Bioclimatic Regional Classification of Scandinavia). Svensk Geografisk Arsbok 35. Lund.

- r960, Klimadiagramm-Karte von Norden. Klimadiagramm-Weltatlas, edit. by $\mathrm{H}$. WALter \& H. Lieth. Jena.

- Växtkraft och klimat ur fyokorologisk synpunkt. Manuscript.

Petterson, H., I95I, Beståndsvårdens ekonomi. Meddelanden från Statens skogsforskningsinstitut. Serien uppsatser $\mathrm{nr}$ 20. Also in Skogsvårdsfören. Tidskr. I95I: 2.

- I955, Barrskogens volymproduktion. Meddelanden frän Statens skogsforskningsinstitut, Band 45, Nr I. Stockholm.

Pisek, A. \& Tranguillini, W., I954, Assimilation und Kohlenstoffhaushalt in der Krone von Fichten- (Picea excelsa Link) und Rotbuchenbäumen (Fagus silvatica L.). Flova, Jahrg. I4I. Jena.

Polster, H., I950, Die physiologischen Grundlagen der Stofferzeugung im Walde. Untersuchungen über Assimilation, Respiration und Transpiration unserer Hauptholzarten. München.

Robertson, C. J., I958, Sten Sture Paterson: The Forest Area Of The World And Its Potential Productivity. The Geographical Journal, September I958.

RoMelL, L.-G., I925, Växttidsundersökningar å tall och gran. (Recherches sur la marche de l'acchoissement chez le pin et l'épicéa durant la période de végétation). Meddelanden frän Statens Skogsförsöksanstalt, hf. 22, N:o 2. Stockholm.

Rostlund, E., I959, Potential Productivity Of The World's Forests. Geographical Review, Vol. XLIX, No 2. New York.

Rubner, K:, I934, Die pflanzengeographisch-ökologischen Grundlagen des Waldbaus. Neudamm.

Rudberg, S., I957, Ödemarkerna och den perifera bebyggelsen i inre Nordsverige. En diskussion av vissa orsakssamband bakom fördelningen bygd-obygd (Unsettled Areas and Frontier Settlement Areas in Inner Northern Sweden). Geographica, Nr 33, Uppsala.

Schimper, A. F., I898, Pflanzengeographie auf physiologischer Grundlage. 3. Aufl., hrsg. V. F. C. Faber. 2 Bde. Jena 1935.

StridsberG, E., I958, Några synpunkter på bonitetsbegreppet och dess internationella jämförbarhet. Sv. Skogsvairdsfören. Tidskr., I958: 4. Norrtälje.

StÅLfELT, M. G., I944, Granens vattenförbrukning. Kungl. Lantbruksakad. Tidskrift, 83. Stockholm.

- I956, Vattnets rörelse i moränjord och marktäcke. Dansk Skovforenings Tidskrift, Bind XLI. København.

SöDERSTRÖM, V., I959, Några orienterande studier angående marktemperatur och barrträdsplantors rottillväxt i plantrutor och under hyggesvegetation. Sv. Skogsvårdsföreningens Tidskrift, Årg. 57, Nr I o. 2. Norrtälje.

TAMm, O. F. S., I959, Studier över klimatets humiditet i Sverige (Studien über die Humidität des Klimas in Schweden). Kungl. Skogshögskolans Skrifter, Nr 32. Stockholm.

Tranguillini, W., see Pisek, A. \& Tranquillini, W., I954.

- I959, Die Stoffproduktion der Zirbe (Pinus Cembra L.) and der Waldgrenze während eines Jahres. Planta 54. Würzburg.

WALlÉN, C. C., I95I, Nederbörden i Sverige. Medelvärden I9oI-I930. (Precipitation in Sweden). Meddelanden fran Sveriges Meteorologiska och Hydrologiska Institut. Ser. A. Nr. 4. Sthlm.

8-MSS, $50: 5$ 
WALter, H., I955, Die Klimadiagramme als Mittel zur Beurteilung der Klimaverhältnisse für ökologische, vegetationskundliche und landwirtschaftliche Zwecke. Ber. Deutsch. Bot. Ges. 68.

- I957, Die Klima-Diagramme der Waldsteppen- und Steppengebiete in Osteuropa. Lautensach-Festschrift, Stuttgarter Geographische Studien, Band 69. Stuttgart.

- \& Lieth, H., Klimadiagramm - Weltatlas. Jena.

Wassink, E. C., I956, The Mechanism of Photosynthesis. Radiation Biology, Vol. III: Visible and Near-Visible Light. Edit. by Alex. Hollænder.

WECK, J., I955, Forstliche Zuwachs- und Ertragskunde. Radebeul und Berlin.

- 1957, Neuere Versuche zum Problem der Korrelation: Klima und forstliches Produktionspotential. Forstarchiv, 28. Jahrg., Heft II. Hannover-Waldhausen.

- I958, Sten Sture Paterson: The Forest Area Of The World And Its Potential Productivity. Die Erde, Heft 2. Berlin.

- I959, Regenwälder, eine vergleichende Studie forstliches Produktionspotentials. Die Erde, Heft I. Berlin.

VÉzINA, P.-E., r96o, Recherches sur les conditions de lumière et de précipitations dans les forets traitées par la coupe progressive par groupes. Mitteilungen der Schweizerischen Anstalt für das Forstliche Versuchswesen. Bd. 36, Heft 2. Zürich.

Wilhelmr, Tн., I959, Ein Testversuch über die Abhängigkeit des Dickenwachstums der Bäume von der Globalstrahlung und Lufttemperatur. Allgemeine Forst-und JagdZeitung, I30. Jahrg., H. 7. Frankfurt A/M.

ÅNGSTRÖM, A., I938, Lufttemperatur och temperaturanomalier i Sverige I90I-r93o. Meddelande frän Statens Meteorologisk-Hydrografiska Anstalt. Band 7. N:o 2. Stockholm.

- I946, Sveriges Klimat. Stockholm. 
Table I. Yield data of the sample plots.

\begin{tabular}{|c|c|c|c|c|c|c|c|c|c|c|}
\hline \multirow{3}{*}{$\begin{array}{l}\text { Cur- } \\
\text { rent } \\
\text { No. }\end{array}$} & \multirow{3}{*}{$\begin{array}{l}\text { Sam- } \\
\text { ple } \\
\text { plot } \\
\text { No. }\end{array}$} & \multirow{3}{*}{ Province } & \multirow{3}{*}{$\begin{array}{c}\text { Site } \\
\text { index } \\
\text { of } \\
\text { Pine } \\
\mathrm{h}_{100} 1 \\
\text { meter }\end{array}$} & \multirow{3}{*}{ Age } & \multicolumn{4}{|c|}{ Volume of green timber } & \multicolumn{2}{|c|}{$\begin{array}{c}\text { Annual mean } \\
\text { increment }\end{array}$} \\
\hline & & & & & Pine & Spruce & $\begin{array}{l}\text { Broad- } \\
\text { leaved } \\
\text { species }\end{array}$ & Total & $\begin{array}{r}\text { Green } \\
\text { timber }\end{array}$ & $\begin{array}{c}\text { Green } \\
\text { timber } \\
+ \text { esti- } \\
\text { mated } \\
\text { mor- } \\
\text { tality }\end{array}$ \\
\hline & & & & & \multicolumn{6}{|c|}{$\mathrm{m}^{3}$ per hectare over bark } \\
\hline I & 725 & Kristianstad & 24.2 & IO4 & 387.2 & $93 \cdot 7$ & 0.0 & 480.9 & 4.6 & 6.3 \\
\hline 2 & $9^{8}$ & $»$ & $24 \cdot 7$ & 112 & 219.5 & $224 \cdot 9$ & 0.0 & $444 \cdot 4$ & 4.0 & 5.6 \\
\hline 3 & 300 & 》 & 29.6 & $\mathrm{IO}_{4}$ & 234.2 & $345 \cdot 5$ & $4 \cdot 2$ & 583.9 & 5.6 & $7 \cdot 7$ \\
\hline 4 & 3OI & $»$ & 28.7 & 106 & I72.3 & 450.4 & II.O & 633.7 & 6.0 & 8.3 \\
\hline 5 & 506 & Blekinge & 23.0 & 85 & 272.9 & 74.4 & I. 8 & 349.1 & $4 . I$ & 5.2 \\
\hline 6 & 508 & " & 27.4 & IOO & 257.9 & $293 \cdot 7$ & 0.0 & 55 I. 6 & $5 \cdot 5$ & $7 \cdot 4$ \\
\hline 7 & 502 & ' & 24.9 & Io6 & I 47.9 & I 83.7 & I05.9 & $437 \cdot 5$ & $4 . I$ & $5 \cdot 7$ \\
\hline 8 & 708 & Halland & 29 & 72 & 416.2 & 0.0 & 0.3 & 416.5 & 8 & 6.8 \\
\hline 9 & $7 \mathrm{I} 4$ & i) & $25 . \mathrm{I}$ & $9 \mathrm{I}$ & 82.8 & 302.4 & - & 385.2 & 4.2 & $5 . \mathrm{I}$ \\
\hline Io & 7 I0 & $"$ & 23.5 & 105 & 316.2 & $\mathrm{II} 4.8$ & $47 \cdot 5$ & 478.5 & 4.6 & 6.2 \\
\hline I I & 740 & Kronoberg & $25 \cdot 4$ & 84 & 335.4 & 2.2 & O.I & 337.7 & 4.0 & 5.0 \\
\hline I2 & I69 & 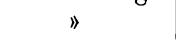 & 24.4 & 97 & 360.3 & 0.2 & 6.7 & 367.2 & 3.8 & 5.0 \\
\hline I3 & 549 & $»$ & 24.9 & I 6 & 344.4 & 205.5 & - & 549.9 & $4 \cdot 7$ & 6.9 \\
\hline I 4 & $54 \mathrm{I}$ & " & 20.4 & 105 & I 26.9 & 142.5 & 23.0 & 292.4 & 2.8 & 3.6 \\
\hline I 5 & 746 & $»$ & 25.9 & 80 & $217 \cdot 3$ & 93.0 & O.I & 310.4 & $3 \cdot 9$ & 4.8 \\
\hline I6 & 804 & Jönköping & I 8.8 & II 7 & I 53.5 & I77.9 & 7.8 & 339.2 & 2.9 & $3 \cdot 9$ \\
\hline I7 & I 16 & $\gg$ & $25 \cdot 5$ & $8 \mathrm{I}$ & I 83.2 & $2 \times 2.6$ & $7 \cdot 7$ & $403 \cdot 5$ & 5.0 & 6.1 \\
\hline I 8 & I I I & $"$ & 24.6 & 93 & 52.5 & 339.I & - & 391.6 & 4.2 & $5 . \mathrm{I}$ \\
\hline I9 & 822 & $\gg$ & $25 \cdot 3$ & 89 & I 79.7 & I 7 1.6 & I.8 & $353 . \mathrm{I}$ & 4.0 & $5 . \mathrm{I}$ \\
\hline 20 & 823 & 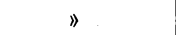 & 22.2 & 98 & I62.I & I 88.8 & I3.3 & 364.2 & $3 \cdot 7$ & 4.8 \\
\hline $2 \mathrm{I}$ & I09 & 》 & $2 \mathrm{I} .5$ & II 3 & I 53.6 & 212.0 & 5.7 & $37 \mathrm{I} \cdot 3$ & $3 \cdot 3$ & $4 \cdot 5$ \\
\hline 22 & 108 & 》 & 23.0 & $9 \tilde{6}$ & 99.8 & 365.6 & - & 465.4 & 4.8 & 6.0 \\
\hline 23 & IOO & $"$ & $25 \cdot 7$ & 82 & I92.5 & 223.0 & O.I & 4 I 5.6 & 5. I & 6.2 \\
\hline 24 & $80 I$ & ») & 25.8 & 93 & 356.0 & I 54.7 & I7.0 & 527.7 & $5 \cdot 7$ & $7 \cdot 4$ \\
\hline 25 & $\mathrm{IO}_{4}$ & $\gg$ & 21.0 & 96 & $77 \cdot 4$ & I 74.2 & - & 25 I.6 & 2.6 & 3.4 \\
\hline 26 & I03 & $\gg$ & $2 \mathrm{I} .4$ & I I 5 & 280.3 & 53.0 & - & $333 \cdot 3$ & 2.9 & $4 . I$ \\
\hline 27 & I73 & Kalmar & 20.8 & IO3 & 273.7 & I.7 & 0.0 & 275.4 & 2.7 & $3 \cdot 5$ \\
\hline 28 & I74 & " & 25.0 & IIO & 339.6 & I 12.8 & 0.0 & $45^{2.4}$ & 4.I & 5.8 \\
\hline 29 & 519 & » & 24.6 & I 6 & 359.6 & $44 \cdot 4$ & O.I & $404 . \mathrm{I}$ & $3 \cdot 5$ & 5.0 \\
\hline 30 & 50 & » & I 7.5 & IOO & 252.2 & I. 5 & - & 253.7 & 2.5 & 3.0 \\
\hline $3 I$ & 49 & $\gg$. & 20.7 & 94 & 259.5 & 0.0 & 6.0 & 265.5 & 2.8 & 3.6 \\
\hline 32 & $5^{\mathrm{I}}$ & $»$ & $23 \cdot 3$ & 107 & 3 I 2.5 & II2.I & - & 424.6 & 4.0 & 5.6 \\
\hline 33 & 53 & $"$ & 28.3 & 85 & 48.4 & 342.2 & $53 \cdot 4$ & 444.0 & 5.2 & 6.5 \\
\hline 34 & 60 & $»$ & 25.5 & 120 & 309.8 & I 55.2 & 0.0 & 465.0 & $3 \cdot 9$ & $5 \cdot 7$ \\
\hline 35 & $6 I$ & $»$ & 22.9 & IO4 & $37 \mathrm{I} . \mathrm{I}$ & 0.4 & 5.I & 376.6 & 3.6 & 5. I \\
\hline 36 & 397 & Gotland & I $7 . \mathrm{I}$ & 99 & $220 . I$ & - & - & $220 . \mathrm{I}$ & 2.2 & 2.6 \\
\hline 37 & 306 & Älvsborg & 27.0 & 82 & I 12.3 & 320.6 & 21.6 & $454 \cdot 5$ & $5 \cdot 5$ & 6.8 \\
\hline $3^{8}$ & 312 & " & 27.7 & 107 & 309.5 & 312.0 & 30.7 & $\begin{array}{l}4 J 4 \cdot J \\
652.2\end{array}$ & 6.1 & 8.4 \\
\hline 39 & 303 & $"$ & 29.9 & 82 & 221.0 & 237.8 & - & $45^{8.8}$ & 5.6 & 6.9 \\
\hline 40 & $75^{\circ}$ & $"$ & 20.8 & IOI & 272.6 & I $8 \mathrm{I} .8$ & 0.2 & 454.6 & 4.5 & 5.9 \\
\hline $4 I$ & 764 & $»$ & 20.2 & 95 & II0.8 & I9I.7 & $4 \cdot 4$ & 306.9 & 3.2 & 4.0 \\
\hline 42 & $\mathrm{I}_{4} \mathrm{I}$ & Skaraborg & 22.2 & 98 & 283.0 & 36.2 & - & 319.2 & $3 \cdot 3$ & $4 \cdot 4$ \\
\hline 43 & 645 & $\|$ & 26.3 & II 4 & $455 \cdot 3$ & $\mathrm{r} 48.8$ & - & $604 . I$ & $5 \cdot 3$ & 7.6 \\
\hline 44 & 644 & $»$ & 23.7 & 108 & 306.8 & I 45.6 & - & $45^{2.4}$ & 4.2 & 5.9 \\
\hline 45 & 385 & $"$ & 25.4 & 82 & 90.6 & 2 I2.6 & I 34.5 & 437.7 & $5 \cdot 3$ & 6.6 \\
\hline
\end{tabular}

1 Height of the largest tree at Ioo years. 


\begin{tabular}{|c|c|c|c|c|c|c|c|c|c|c|}
\hline \multirow{3}{*}{$\begin{array}{l}\text { Cur- } \\
\text { rent } \\
\text { No. }\end{array}$} & \multirow{3}{*}{$\begin{array}{l}\text { Sam- } \\
\text { ple } \\
\text { plot } \\
\text { No. }\end{array}$} & \multirow{3}{*}{ Province } & \multirow{3}{*}{$\begin{array}{c}\text { Site } \\
\text { index } \\
\text { of } \\
\text { Pine } \\
\mathrm{h}_{100}{ }^{1} \\
\text { meter }\end{array}$} & \multirow{3}{*}{ Age } & \multicolumn{4}{|c|}{ Volume of green timber } & \multicolumn{2}{|c|}{$\begin{array}{c}\text { Annual mean } \\
\text { increment }\end{array}$} \\
\hline & & & & & Pine & Spruce & $\begin{array}{c}\text { Broad- } \\
\text { leaved } \\
\text { species }\end{array}$ & Total & $\begin{array}{c}\text { Green } \\
\text { timber }\end{array}$ & $\begin{array}{l}\text { Green } \\
\text { timber } \\
+ \text { esti- } \\
\text { mated } \\
\text { mor- } \\
\text { tality }\end{array}$ \\
\hline & & & & & \multicolumn{6}{|c|}{$\mathrm{m}^{3}$ per hectare over bark } \\
\hline 46 & 749 & Skaraborg & 26.I & 86 & $24 \mathrm{r} \cdot 5$ & 3.8 & 54.9 & 300.2 & $3 \cdot 5$ & 4.4 \\
\hline 47 & 126 & $\|$ & $29 \cdot 3$ & 83 & $293 \cdot 5$ & I60.9 & - & $454 \cdot 4$ & $5 \cdot 5$ & 6.8 \\
\hline $4^{8}$ & I 25 & $》$ & $25 \cdot 5$ & II 2 & 393.8 & I 56.2 & - & 550.0 & 4.9 & 7.0 \\
\hline 49 & I 24 & $»$ & 26.7 & $8 \mathrm{I}$ & 86.3 & $34 I .9$ & $4 \cdot 3$ & 432.5 & $5 \cdot 3$ & 6.6 \\
\hline 50 & 319 & $\therefore \quad "$ & 22.4 & 86 & I39.8 & $237 \cdot 5$ & I.I & 378.4 & $4 \cdot 4$ & 5.6 \\
\hline $5 \mathrm{I}$ & 66 & Östergötl. & $2 I .4$ & 88 & 242.6 & 2.5 & I 8.4 & 263.5 & 3.0 & $3 \cdot 7$ \\
\hline $5^{2}$ & $7 \mathrm{I}$ & . . 1 & 25.9 & 107 & 402.5 & 34.6 & o.I & 437.2 & $4 . I$ & $5 \cdot 7$ \\
\hline 53 & 78 & $"$ & 26.8 & 98 & 448.9 & 56.0 & o.r & 505.0 & 5.2 & 6.9 \\
\hline 54 & 76 & .. $\gg$ & 26.2 & 92 & 353.4 & $8 \mathrm{I} .8$ & - & 435.2 & $4 \cdot 7$ & 6.1 \\
\hline 55 & $65^{8}$ & Örebro & 26.0 & 97 & 476.3 & II0.6 & - & 586.9 & 6.I & 8. I \\
\hline $5^{6}$ & 653 & 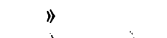 & $25 \cdot 5$ & 85 & $309 \cdot 3$ & I 35.2 & - & $444 \cdot 5$ & 5.2 & 6.6 \\
\hline 57 & 732 & i) & $25 \cdot 3$ & 84 & 7 I.I & 278.8 & 65.4 & $4 \times 5.3$ & $4 \cdot 9$ & 6.1 \\
\hline $5^{8}$ & $26 I$ & " & $24 \cdot 7$ & 85 & I 8.6 & 260.8 & $3 \cdot I$ & 382.5 & $4 \cdot 5$ & 5.6 \\
\hline 59 & $28 \mathrm{I}$ & " & 23.0 & $\operatorname{II} 4$ & 282.6 & I 47.8 & -1 & 430.4 & 3.8 & $5 \cdot 3$ \\
\hline 60 & 284 & $》$ & I6.6 & 117 & $225 \cdot 5$ & 1.6 & - & $227 . I$ & r.9 & 2.4 \\
\hline $6 \mathrm{I}$ & 276 & $»$ & $\mathrm{I} 7.7$ & 84 & 91.6 & I36.9 & 8.0 & 236.5 & 2.8 & 3.2 \\
\hline 62 & 259 & 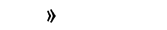 & 26.5 & 85 & $2 \mathrm{I} 5 \cdot 7$ & 35.5 & $5 \mathrm{I} \cdot 3$ & 302.5 & 3.6 & 4.5 \\
\hline 63 & 208 & Södermanl. & 23.0 & I03 & 268.8 & I 23.2 & 0.0 & 392.0 & 3.8 & $4 \cdot 7$ \\
\hline 64 & 200 & » & $24 \cdot 3$ & 96 & $\mathrm{I} 74 . \mathrm{I}$ & 285.0 & 26.6 & 485.7 & $5 . \mathrm{I}$ & 6.7 \\
\hline 65 & 223 & $\|$ & 24.0 & I I 5 & 345.4 & I97.7 & 0.0 & 543.I & $4 \cdot 7$ & 6.8 \\
\hline 66 & $24 \mathrm{I}$ & Stockholm & $27 \cdot 7$ & I 16 & $55^{8.5}$ & 169.4 & 0.4 & 728.3 & 6.3 & 9.I \\
\hline 67 & 245 & " & 22.6 & 87 & I 80.4 & I02.9 & 24.9 & 308.2 & 3.5 & 4.4 \\
\hline 68 & 242 & ॥ & 23.6 & 89 & $64 . I$ & 339.7 & $3 \cdot 7$ & 407.5 & 4.6 & $5 \cdot 7$ \\
\hline 69 & 240 & $"$ & 26.2 & I Io & $503 \cdot 5$ & 46.2 & 6.4 & $55^{6 . I}$ & 5.1 & 7.1 \\
\hline 70 & 327 & Uppsala & 22.0 & I I 8 & $335 \cdot 7$ & 45.9 & - & 381.6 & 3.2 & $4 \cdot 7$ \\
\hline $7 x$ & 324 & , & 19.5 & 93 & 107.6 & 106.5 & 一 & $2 \mathrm{I} 4 . \mathrm{I}$ & 2.3 & 2.8 \\
\hline 72 & 3 & Västmanl. & 22.0 & 109 & 231.9 & IO9.I & - & 341.0 & $3 . \mathrm{I}$ & $4 \cdot 4$ \\
\hline 73 & I & 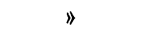 & $2 \mathrm{I} .2$ & 96 & 126.5 & 160.7 & - & 287.2 & 3.0 & $3 \cdot 9$ \\
\hline 74 & I3 & $»$ & 23.6 & $8 I$ & 255.2 & I38.9 & - & $394 . I$ & $4 \cdot 9$ & $6 . I$ \\
\hline 75 & 39 & 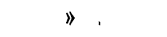 & I 4.4 & IIO & I $4 \mathrm{I} . \mathrm{O}$ & I. & 4.2 & 146.2 & 1.3 & 1.5 \\
\hline 76 & 32 & . & $27 \cdot 4$ & I 3 & 392.2 & I82.2 & - & $574 \cdot 4$ & 5. I & 7.9 \\
\hline 77 & 493 & Värmland & 20.0 & 72 & I 56.4 & 0.0 & I.9 & I 58.3 & 2.2 & 2.5 \\
\hline 78 & 492 & $\|$ & I6.5 & 84 & I $42 . \mathrm{I}$ & - & 0.5 & 142.6 & $\mathrm{x} .7$ & I. 8 \\
\hline 79 & 489 & 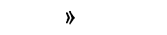 & 21.4 & 82 & 219.4 & 6.7 & - & $226 . I$ & 2.8 & $3 \cdot 4$ \\
\hline 80 & $45^{2}$ & 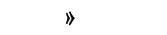 & 27.4 & 85 & $243 . I$ & 89.5 & $4 \mathrm{I} .2$ & 373.8 & $4 \cdot 4$ & $5 \cdot 5$ \\
\hline $8 I$ & 299 & $\gg$ & I 4.8 & 85 & I09.0 & $32 . \mathrm{I}$ & $5 \cdot 3$ & I 46.4 & 1.7 & I. 8 \\
\hline 82 & 418 & Kopparberg & I 7.1 & 102 & 221.5 & 0.4 & I. 5 & 223.4 & 2.2 & 2.6 \\
\hline 83 & 419 & 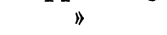 & I8.o & 100 & 206.4 & 0.0 & 5.6 & 212.0 & $2 . I$ & 2.6 \\
\hline 84 & $42 I$ & $»$ & 21.0 & II 5 & 302.7 & o.I & $8 . I$ & 310.9 & 2.7 & 3.8 \\
\hline 85 & I294 & $»$ & 22.7 & 72 & I65.8 & I 27.8 & 80.2 & 373.8 & 5.2 & 6.2 \\
\hline 86 & I 297 & 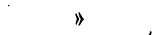 & I 4.0 & 80 & I90.9 & I.8 & 2.7 & I 95.4 & 2.4 & 2.4 \\
\hline 87 & x99 & » & I 7.2 & 95 & 272.6 & I.O & - & 273.6 & 2.9 & $3 \cdot 3$ \\
\hline 88 & 693 & " & 20.6 & II3 & 279.0 & $47 \cdot 7$ & I5.7 & 342.4 & 3.0 & 4.2 \\
\hline 89 & 408 & " & $2 \mathrm{I} .3$ & II6 & 328.5 & 2.4 & -1 & 330.9 & 2.9 & $4 . I$ \\
\hline 90 & I 328 & " & I8.0 & I 24 & $\mathrm{I} 64.0$ & I2.0 & 6.3 & 182.3 & I. 5 & I. 9 \\
\hline $9 I$ & 405 & " & 22.9 & 96 & 339.6 & 5.9 & 0.2 & 345.7 & 3.6 & 4.9 \\
\hline
\end{tabular}

1 Height of the largest tree at roo years. 


\begin{tabular}{|c|c|c|c|c|c|c|c|c|c|c|}
\hline \multirow{3}{*}{$\begin{array}{l}\text { Cur- } \\
\text { rent } \\
\text { No. }\end{array}$} & \multirow{3}{*}{$\begin{array}{l}\text { Sam- } \\
\text { ple } \\
\text { plot } \\
\text { No. }\end{array}$} & \multirow{3}{*}{ Province } & \multirow{3}{*}{$\begin{array}{l}\text { Site } \\
\text { index } \\
\text { of } \\
\text { Pine } \\
\mathrm{h}_{100}{ }^{1} \\
\text { meter }\end{array}$} & \multirow{3}{*}{ Age } & \multicolumn{4}{|c|}{ Volume of green timber } & \multicolumn{2}{|c|}{$\begin{array}{c}\text { Annual mean } \\
\text { increment }\end{array}$} \\
\hline & & & & & Pine & Spruce & $\begin{array}{l}\text { Broad- } \\
\text { leaved } \\
\text { species }\end{array}$ & Total & $\begin{array}{c}\text { Green } \\
\text { timber }\end{array}$ & $\begin{array}{c}\text { Green } \\
\text { timber } \\
+ \text { esti- } \\
\text { mated } \\
\text { mor- } \\
\text { tality }\end{array}$ \\
\hline & & & & & \multicolumn{6}{|c|}{$\mathrm{m}^{3}$ per hectare over bark } \\
\hline 92 & I 89 & Gävleborg & $22 . I$ & 87 & 213.4 & 52.4 & $25 \cdot 5$ & $29 I \cdot 3$ & $3 \cdot 3$ & $4 \cdot 3$ \\
\hline 93 & 335 & $\gg$ & I 5.4 & 84 & I 39.8 & 0.2 & 0.0 & I 40.0 & I.7 & I. 8 \\
\hline 94 & 638 & $\gg$ & I 8.I & 89 & I 50.6 & 2.9 & I.9 & I55.4 & I.7 & 2.0 \\
\hline 95 & 687 & 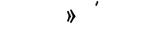 & I9.7 & 87 & I80.4 & O.I & I 7.2 & I97.7 & 2.3 & 2.8 \\
\hline 96 & $33^{8}$ & $»$ & 19.2 & I03 & 200.9 & $63 \cdot 3$ & I0.4 & 274.6 & 2.7 & $3 \cdot 4$ \\
\hline 97 & 677 & 》 & $2 I .9$ & 98 & $274 \cdot I$ & I73.6 & 0.0 & $447 \cdot 7$ & 4.6 & 6.1 \\
\hline 98 & 675 & 》 & 27.9 & 83 & $507 \cdot 7$ & 67.9 & x.6 & 577.2 & 7.0 & 8.6 \\
\hline 99 & 662 & » & $24 \cdot 3$ & 98 & I $57 \cdot 4$ & I30.6 & I 70.7 & $45^{8.7}$ & $4 \cdot 7$ & 6.3 \\
\hline IOO & 685 & " & I8.I & 100 & $269 . I$ & I 5.4 & $3 \cdot 3$ & 287.8 & 2.9 & $3 \cdot 5$ \\
\hline IOI & 680 & » & I 5.9 & I I 4 & I93.2 & 0.0 & I.I & I94.3 & I. 7 & 2.0 \\
\hline 102 & $68 \mathrm{I}$ & 1 & $\mathrm{I} 8.6$ & 107 & $287 . \mathrm{I}$ & 28.6 & 0.5 & 316.2 & 3.0 & 3.7 \\
\hline IO3 & I022 & Jämtland & I 2.0 & 122 & 122.3 & I.8 & 2.6 & I 26.7 & I.O & I.I \\
\hline 104 & 623 & " & I0.9 & $8 \mathrm{I}$ & $5 \mathrm{I} \cdot 7$ & 0.0 & O.I & $5 \mathrm{r} .8$ & 0.6 & 0.6 \\
\hline I05 & 624 & » & I $4 . I$ & 72 & 9I.o & -1 & - & 9r.o & I. 3 & I.3 \\
\hline I06 & 339 & 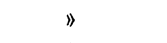 & I 7.7 & IOI & 255.8 & 0.3 & $4 \cdot 3$ & 260.4 & 2.6 & $3 \cdot I$ \\
\hline 107 & IOI 6 & " & 28.7 & 90 & 212.4 & 305.4 & 2.0 & 5 I9.8 & 5.8 & 7.5 \\
\hline 108 & I025 & $»$ & 25.6 & 79 & 339.9 & 56.8 & 0.8 & 397.5 & 5.0 & 6.2 \\
\hline IO9 & 847 & $»$ & I6.4 & $7 I$ & I 59. I & 3.4 & I. 6 & I64.I & 2.3 & 2.5 \\
\hline I Io & $84 \mathrm{I}$ & " & $23 \cdot 3$ & 94 & 260.8 & I I 4.0 & 0.8 & 375.6 & 4.0 & 5.2 \\
\hline I I I & 849 & $》$ & 20.3 & IOI & $359 . \mathrm{I}$ & 70.8 & 42.8 & 472.7 & $4 \cdot 7$ & 6.0 \\
\hline I I 2 & $85 I$ & $"$ & I9.4 & I02 & $407 \cdot 4$ & 0.5 & 3.6 & $4 \mathrm{II} \cdot 5$ & 4.0 & $\begin{aligned} 5.1 \\
5.8\end{aligned}$ \\
\hline I I 3 & 880 & Västernorrl. & $25 \cdot 3$ & 97 & 249.5 & 245.4 & - & 494.9 & $5 . I$ & 6.8 \\
\hline I I 4 & 613 & " & 22.6 & 83 & I 53.2 & $207 \cdot 3$ & - & 360.5 & $4 \cdot 3$ & $5 \cdot 4$ \\
\hline I I 5 & 858 & Jämtland & I9.I & $8 I$ & I 75.9 & 0.0 & - & I75.9 & 2.2 & 2.6 \\
\hline I 6 & 896 & Västernorrl. & 20.6 & 89 & $242 . I$ & 6.7 & 0.4 & 249.2 & 2.8 & $3 \cdot 4$ \\
\hline I I 7 & Io3o & Jämtland & 23.2 & 88 & 306.3 & $7 \cdot 9$ & - & 314.2 & 3.6 & $4 \cdot 5$ \\
\hline I I 8 & IO44 & $»$ & I 8.7 & I07 & 200.9 & $95 . I$ & I 2.6 & 308.6 & 2.9 & 3.6 \\
\hline I I9 & 1036 & " & 20.9 & 90 & $254 \cdot 3$ & 8.7 & 0.4 & 263.4 & 2.9 & $3 \cdot 7$ \\
\hline 120 & III3 & Västernorrl. & 23.0 & 97 & $347 \cdot 5$ & $95 \cdot 3$ & I I.I & 453.9 & $4 \cdot 7$ & 6.2 \\
\hline I 2 I & IIO4 & $»$ & I9.9 & I 14 & $4 \mathrm{I} 6.2$ & $3 \cdot 4$ & I.7 & $421 \cdot 3$ & $3 \cdot 7$ & 5.0 \\
\hline 122 & III 7 & 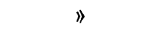 & 22.0 & 93 & 226.5 & $0 . \mathrm{I}$ & I.5 & $228 . \mathrm{I}$ & 2.5 & 3.2 \\
\hline I 23 & III 6 & 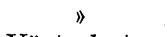 & $23 \cdot 3$ & 95 & 248.6 & o.I & I. 7 & 250.4 & 2.6 & 3.6 \\
\hline I 24 & 1284 & Västerbot. & I9.6 & I09 & I 36.7 & I 28.7 & - & 265.4 & 2.4 & 3.1 \\
\hline 125 & 555 & $\gg$ & 20.4 & 85 & I 73.9 & I5.4 & $35 \cdot 7$ & 225.0 & 2.6 & 3.2 \\
\hline 126 & II 48 & $»$ & I 5.0 & I09 & I $13 \cdot 3$ & 26.3 & I2.6 & $\mathrm{I} 5^{2.2}$ & $\mathrm{x} .4$ & I. 5 \\
\hline 127 & $77 x$ & $»$ & I6.9 & I I 2 & I96.0 & 6.8 & - & 202.8 & I. 8 & 2.2 \\
\hline I 28 & 772 & 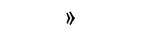 & I 7.6 & 107 & 209.6 & I4.6 & $5 \cdot 4$ & 229.6 & $2 . I$ & 2.6 \\
\hline 129 & 773 & $"$ & 21.3 & $9 \mathrm{I}$ & 311.6 & 0.7 & $4 \cdot \mathrm{I}$ & 316.4 & $3 \cdot 5$ & $4 \cdot 4$ \\
\hline 130 & 560 & $"$ & 22.2 & 85 & $227 \cdot 7$ & 20.5 & 26.3 & $274 \cdot 5$ & 3.2 & 4. I \\
\hline I 3 I & 564 & $"$ & I9.8 & 90 & 127.2 & - & - & 127.2 & I. 4 & I. 7 \\
\hline I 32 & 565 & $»$ & I 7.0 & 95 & I 86. I & II.I & - & I97.2 & $2 . I$ & 2.4 \\
\hline I33 & $57 \mathrm{I}$ & $"$ & $2 \mathrm{I} .2$ & IOO & 257.0 & $65 \cdot 3$ & - & 322.3 & 3.2 & $4 \cdot 2$ \\
\hline I34 & 579 & $"$ & $x 6.6$ & 90 & I $29 . \mathrm{I}$ & I.2 & - & 1 30.3 & I. 4 & I. 6 \\
\hline I35 & I $25^{8}$ & " & I9.6 & IOI & $I_{40.5}$ & $4^{8.5}$ & 88.0 & 277.0 & 2.7 & 3.5 \\
\hline I36 & I 257 & 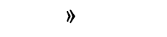 & 2 I. 6 & 95 & $\mathrm{I} 55 . \mathrm{I}$ & 5.9 & 31.8 & I92.8 & 2.0 & 2.6 \\
\hline I 37 & I 280 & 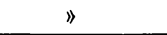 & I6. 5 & 108 & $\mathrm{I} 84.2$ & -1 & - & I 84.2 & I. 7 & 2.0 \\
\hline
\end{tabular}

1 Height of the largest tree at roo years. 


\begin{tabular}{|c|c|c|c|c|c|c|c|c|c|c|}
\hline \multirow{3}{*}{$\begin{array}{l}\text { Cur- } \\
\text { rent } \\
\text { No. }\end{array}$} & \multirow{3}{*}{$\begin{array}{l}\text { Sam- } \\
\text { ple } \\
\text { plot } \\
\text { No. }\end{array}$} & \multirow{3}{*}{ Province } & \multirow{3}{*}{$\begin{array}{c}\text { Site } \\
\text { index } \\
\text { of } \\
\text { Pine } \\
\mathrm{h}_{100}{ }^{1} \\
\text { meter }\end{array}$} & \multirow{3}{*}{ Age } & \multicolumn{4}{|c|}{ Volume of green timber } & \multicolumn{2}{|c|}{$\begin{array}{c}\text { Annual mean } \\
\text { increment }\end{array}$} \\
\hline & & & & & Pine & Spruce & $\begin{array}{l}\text { Broad- } \\
\text { leaved } \\
\text { species }\end{array}$ & Total & $\begin{array}{l}\text { Green } \\
\text { timber }\end{array}$ & $\begin{array}{l}\text { Green } \\
\text { timber } \\
+ \text { esti- } \\
\text { mated } \\
\text { mor- } \\
\text { tality }\end{array}$ \\
\hline & & & & & \multicolumn{6}{|c|}{$\mathrm{m}^{3}$ per hectare over bark } \\
\hline I38 & I 290 & Västerbot. & $23 \cdot 3$ & 83 & 279.0 & 22.7 & 2.5 & 304.2 & $3 \cdot 7$ & $4 \cdot 5$ \\
\hline I 39 & $\mathrm{I} 204$ & $"$ & I 5.2 & 93 & 163.3 & 8.3 & - & I 71.6 & I. 8 & 2.0 \\
\hline I 40 & I 453 & $»$ & I 8.4 & $8 I$ & I 70.0 & 8.7 & 20.5 & I99.2 & 2.5 & 2.8 \\
\hline I 4 I & I 434 & 》 & I $8 \cdot 3$ & 89 & 239.8 & $2 \cdot 3$ & 5.8 & $247 \cdot 9$ & 2.8 & $3 \cdot 3$ \\
\hline I 42 & I $44 \mathrm{I}$ & $\gg$ & 22.6 & $9 I$ & 265.8 & $\mathrm{I} .5$ & $9 . \mathrm{I}$ & 276.4 & 3.0 & $3 \cdot 9$ \\
\hline I 43 & 776 & $》$ & I6.8 & 92 & $213 \cdot 7$ & - & - & $2 \mathrm{I} 3 \cdot 7$ & 2.3 & 2.6 \\
\hline I 44 & 775 & 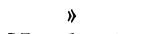 & I9.I & 82 & I9I.7 & I0.5 & $27 \cdot 7$ & 229.9 & 2.8 & 3.2 \\
\hline I 45 & 967 & Norrbotten & I 5.6 & 92 & III.3 & I 8.5 & - & I 29.8 & I. 4 & I. 5 \\
\hline I 46 & $973 \mathrm{~A}$ & " & I6.7 & 96 & $\mathrm{I} 44.6$ & 0.4 & I.I & I 46.I & I. 5 & I. 7 \\
\hline I 47 & 973 & $»$ & I6.I & 90 & I00.6 & I.2 & 0.4 & I02.2 & I.I & I. 2 \\
\hline$I_{48}$ & 970 & 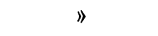 & 20.0 & 83 & 90.0 & 92.3 & 27.8 & 2 IO.I & 2.5 & 3.0 \\
\hline I 49 & 905 & $»$ & I 8.7 & 107 & 2OI.I & $4 \cdot 4$ & 17.0 & 222.5 & $2 . I$ & 2.6 \\
\hline I 50 & 9 I 3 & $"$ & I 4.7 & 88 & I36.8 & - & - & I36.8 & I. 6 & I. 6 \\
\hline I 5 I & 933 & $\gg$ & I 7.8 & 83 & $54 \cdot 7$ & 29.2 & 39.9 & I 23.8 & I. 5 & I. 7 \\
\hline I 52 & 930 & $»$ & I9.0 & 86 & I 75.9 & -1 & I 5.9 & I9I.8 & 2.2 & 2.6 \\
\hline I 53 & 935 & " & 14.2 & 84 & I 13.7 & $\mathrm{I}_{4.4}$ & -1 & I $28 . \mathrm{I}$ & I. 5 & I. 6 \\
\hline I 54 & 1087 & " & 23.8 & 93 & I 5 I. 7 & $5 \cdot 9$ & 80.5 & $238 . I$ & 2.6 & $3 \cdot 3$ \\
\hline I 55 & 1078 & $"$ & I 7.4 & 85 & I I6.6 & o.I & $4 \cdot 4$ & I 2 I.I & I. 4 & I. 6 \\
\hline I 56 & I082 & 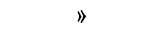 & I 7.6 & 79 & I39.9 & - & 9.0 & $\mathrm{I}_{48} 8.9$ & I. 9 & 2.1 \\
\hline I 57 & $95^{8}$ & $"$ & I9.9 & IIO & I98.9 & 4.6 & I 7.5 & 221.0 & 2.0 & 2.7 \\
\hline I 58 & 947 & " & I 7.0 & 96 & 69.5 & 23.9 & 59.8 & I 53.2 & I. 6 & I. 9 \\
\hline I 59 & 987 & $"$ & I 5.7 & 88 & IO3. 3 & $2 \mathrm{I}, \mathrm{I}$ & I $4 \cdot 3$ & I 38.7 & I. 6 & I. 7 \\
\hline I 60 & 994 & 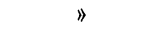 & I7.I & 89 & I 72.9 & -1 & - & I 72.9 & I. 9 & 2.2 \\
\hline I6I & $99 I$ & " & I $5 . \mathrm{I}$ & 97 & I 22.8 & 7.8 & I 4.5 & I $45 . \mathrm{I}$ & I. 5 & г. 6 \\
\hline I62 & 992 & $"$ & I6.0 & $9 I$ & I67.7 & I.I & I6.2 & I 85.0 & 2.0 & 2.2 \\
\hline 163 & 995 & " & I 5.4 & 94 & I36.7 & - & - & I 36.7 & I. 5 & I. 6 \\
\hline I64 & 989 & 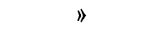 & I6.6 & I I 3 & I 24.4 & 34.9 & 30.6 & I 89.9 & I. 7 & 2.0 \\
\hline I65 & I 422 & 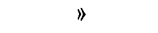 & 22.0 & 96 & I92.0 & $3 \cdot I$ & 23.9 & 219.0 & 2.3 & 3.0 \\
\hline I66 & I $43^{\circ}$ & " & I6. 4 & 99 & 220.6 & 0.4 & II. 5 & 232.5 & 2.3 & 2.7 \\
\hline I 67 & 1404 & $"$ & I6.I & 93 & I69.5 & 2.9 & 12.3 & I 84.7 & 2.0 & 2.2 \\
\hline I 68 & 997 & $"$ & I 5.4 & 89 & I $44 \cdot 3$ & 0.8 & $4 \cdot I$ & I 49.2 & I. 7 & I. 8 \\
\hline I69 & I 062 & $\gg$ & $2 \mathrm{I} \cdot 7$ & 90 & $20 \mathrm{I} .5$ & $4 \cdot 7$ & I6.5 & 222.7 & 2.5 & 3.2 \\
\hline 170 & Io63 & $»$ & I 8.9 & 90 & 92.4 & I.I & 75.8 & I69.3 & I. 9 & 2.3 \\
\hline I7I & I069 & $"$ & I 7.0 & 72 & I 29.2 & - & - & I 29.2 & I. 8 & I. 9 \\
\hline I 72 & I 405 & " & I 6.7 & 95 & I 53.4 & - & I3.2 & I66.6 & I. 8 & 2.0 \\
\hline I 73 & I 4 I 6 & $\gg$ & I 7.4 . & 84 & I64.5 & -1 & - & I64.5 & 2.0 & 2.2 \\
\hline I 74 & $I_{4} I_{4}$ & 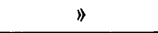 & I9.8 & 92 & $205 . \mathrm{I}$ & I.7 & I.7 & 208.5 & 2.3 & 2.8 \\
\hline
\end{tabular}

1 Height of the largest tree at roo years. 
Table II. Climatological data of the meteorological stations in the Nordic countries

$$
\text { D e } n \text { m.a } \mathbf{r} \text { k }
$$

\begin{tabular}{|c|c|c|c|c|c|c|c|c|}
\hline$N r$ & Station & $\begin{array}{c}\text { A.lt. } \\
\text { m. }\end{array}$ & $\begin{array}{l}{ }_{\mathrm{T}} \\
{ }^{\circ} \mathrm{C}\end{array}$ & $\begin{array}{l}\mathrm{T} \\
\cdot \mathrm{a} \\
{ }^{\circ} \mathrm{C}\end{array}$ & $\begin{array}{l}\mathrm{N} \\
\mathrm{mm}\end{array}$ & $\begin{array}{c}G \\
\text { days }\end{array}$ & $\begin{array}{l}\mathrm{E} \\
\%\end{array}$ & CVP \\
\hline 1 & Skagen Fyr & 3 & 16,0 & 15,7 & 573 & 183 & 70 & 208 \\
\hline 2 & Gaardbogaard & 8 & 15,7 & 16,5 & 625 & 168 & 70 & 194 \\
\hline 3 & Fredrikshavn & 5 & 16,0 & 16,0 & 579 & 177 & 69 & 196 \\
\hline 4 & Raunstrup & 15 & 16,2 & 16,8 & 615 & 171 & 69 & 194 \\
\hline 5 & H jørring & 24. & 15,3 & 15,9 & 646 & 171 & 69 & 204 \\
\hline 6 & Rubjerg Knude Fyr & 67 & 15,3 & 15,6 & 587 & 174 & 69 & 192 \\
\hline 7 & Aagaard & 12 & 15,6 & 15,8 & 671 & 174 & 69 & 221 \\
\hline 8 & Hans tholm $\dot{F} y x$ & 46 & 14,9 & 14,9 & 628 & 174 & 69 & 209 \\
\hline 9 & Thisted & 12 & 15,5 & 15,5 & $7 \cdot 16$ & 178 & 69 & $244^{\circ}$ \\
\hline 10 & $T \phi d s \phi$ & 34 & 15,3 & 15,3 & 695 & 177 & 69 & .236 \\
\hline 11 & Vestervig & 19 & 15,2 & 14,8 & 701 & 183 & 69 & 253 \\
\hline 12 & Thybor $\phi n$ & 3 & 15,4 & 14,8 & 632 & 186 & 68 & 231 \\
\hline 13 & Bovbjerg Fyx & 41 & 15,3 & 15,2 & 709 & 183 & 68 & 247 \\
\hline 14 & Humlum & 25 & 15,3 & 15,3 & 652 & 177 & 68 & 218 \\
\hline 15 & Bœkmarksbro & 8 & 15,4 & $15 ; 4$ & 710 & 175 & 67 & 231 \\
\hline 16 & Bodholt & 90 & 15,6 & 16,4 & 681 & 164 & 67 & 198 \\
\hline 17 & Herning & 54 & 15,6 & 15,9 & 730 & 174 & 67 & 232 \\
\hline 18 & Birkebok Dal & 39 & 15,4 & 16,0 & 762 & 176 & 68 & 244 \\
\hline 19 & Husby & 8 & 15,3 & 15,0 & 7.19 & 180 & 68 & 249 \\
\hline 20 & Staby & 14 & 15,1 & 14,9 & 760 & 177 & 67 & 254 \\
\hline 21 & Lyngrig Fyr & 18 & 15,5 & 15,0 & 687 & 188 & 67 & 248 \\
\hline $2 \dot{2}$ & Tarm & 7 & 15,5 & 15,4 & 713 & 178 & 67 & 238 \\
\hline 23 & Grindsted & 41 & 15,8 & 16,3 & 700 & 175 & 67 & 221 \\
\hline 24 & H $\phi 1$ lund-S $\phi$ gaard & 77 & 15,4 & 15,9 & 758 & 174 & 67 & 238 \\
\hline 25 & Varde & 12 & 15,3 & 15,1 & 755 & 180 & 67 & 256 \\
\hline 26 & Blaavandshuk Fyr & 15 & 15,3 & 14,7 & 504 & 183 & 67 & 179 \\
\hline 27 & As trup & 22 & 15,7 & 15,7 & 654 & 177 & 68 & 219 \\
\hline 28 & Sørang & 3 & 15,0 & 15,4 & 641 & 171 & 68 & 202 \\
\hline 29 & Aalestrup & 23 & 15,4 & 16,0 & 595 & 171 & 68 & 185 \\
\hline 30 & Viborg & 24 & 15,8 & 15,9 & 632 & 178 & 68 & 211 \\
\hline 31 & Askov & 65 & $1.5,6$ & 15,7 & 733 & 177 & 67 & 240 \\
\hline 32 & $\operatorname{Fan} \phi$ & 5 & 15,7 & 15,2 & 687 & 186 & 67 & 246 \\
\hline 33 & Palstrup & 53 & 15,4 & 15,6 & 639 & 174 & 68 & 207 \\
\hline 34 & $\mathrm{Hals}$ & 3 & 16,1 & 16,4 & 556 & 177 & 69 & $185^{\circ}$ \\
\hline 35 & Aalborg I & 3 & 16,4 & 16,3 & 611 & 180 & 69 & 212 \\
\hline 36 & Terndrup & 22 & 15,6 & $16 ; 3$ & 653 & 171 & 69 & 205 \\
\hline 37 & Gjerlev & 34 & 15,7 & 16,0 & 596 & 174 & 68 & 192 \\
\hline 38 & Morke & 42 & 15,7 & 16,0 & 583 & 174 & 68 & 188 \\
\hline
\end{tabular}


$D$ e $n$ m a $r$ (cont.)

Nr Station

$\begin{array}{ccccccc}\text { AIt. } & \mathrm{T}_{\mathrm{v}} & \mathrm{T}_{\mathrm{a}} & \mathrm{N} & \mathrm{G} & \mathrm{E} & \mathrm{CVP} \\ \mathrm{m} \cdot & { }^{\circ} \mathrm{C} & { }^{\circ} \mathrm{C} & \mathrm{mm} & \text { days } & \% & \end{array}$

39 Kolindsund

$\begin{array}{lllllll}3 & 16,2 & 16,5 & 593 & 174 & 68 & 191\end{array}$

40 Norringure

$\begin{array}{lllllll}71 & 15,2 & 15,7 & 650 & 171 & 68 & 203\end{array}$

$4 i$ Kalbygaard

$\begin{array}{lllllll}91 & 15,5 & 16,3 & 670 & 171 & 68 & 206\end{array}$

42 Silkeborg

43 Bryrup

44 Fruergaard

45 Maliing

46 Tringstrup

47 Givskud

48 Vejle

49 Stenderup

50 Randers

51 Gram

52 I 6 gumkloster

53 Tönder

54 Rugbjerg

55 Aabenraa

56 sфinderborg.

5.7 L๓sö

58 Anholt

59 Hessel $\varnothing$

60 Sams $\phi$

61 Baag $\phi$

62 Assens

63 Etterup

64 ABbelф Fyr

65 Hofmansgave

66 Odense

67 Knudshoved

68 Aarsler

69 Egeskov

7.0 Hredholm

71 Svendborg

72 Marstal

73 Stensgaard Mö1l egaard

$\begin{array}{lllllll}30 & 16,1 & 16,3 & 672 & 177 & 68 & 222 \\ 60 & 15,1 & 15,9 & 695 & 169 & 67 & 208\end{array}$

$\begin{array}{lllllll}79 & 15,1 & 15,8 & 696 & 168 & 67 & 208\end{array}$

$\begin{array}{lllllll}50 & 15,6 & 15,7 & 573 & 177 & 67 & 188\end{array}$

$\begin{array}{lllllll}66 & 15,6 & 16,0 & 621 & 174 & 67 & 196\end{array}$

$\begin{array}{lllllll}85 & 15,3 & 16,0 & 680 & 168 & 67 & 203\end{array}$

$\begin{array}{lllllll}3 & 16,8 & 16,4 & 714 & 186 & 67 & 253\end{array}$

$\begin{array}{lllllll}3 & 15,8 & 15,5 & 681 & 183 & 67 & 236\end{array}$

$\begin{array}{lllllll}5 & 16,0 & 16,3 & 58.3 & 174 & 68 & 188\end{array}$

$\begin{array}{lllllll}20 & 15,5 & 15,3 & 740 & 180 & 66 & 247\end{array}$

$\begin{array}{lllllll}14 & 15 ; 4 & 15,1 & 736 & 180 & 66 & 248\end{array}$

$\begin{array}{lllllll}4 & 15,8 & 15,4 & 750 & 182 & 66 & 257\end{array}$

$\begin{array}{lllllll}64 & 15,5 & 15,5 & 747 & 177 & 66 & 242\end{array}$

$\begin{array}{lllllll}5 & 16,1 & 15,7 & 762 & 183 & 66 & 262\end{array}$

$\begin{array}{lllllll}15 & 16,0 & 15,6 & 665 & 186 & 66 & 233\end{array}$

$\begin{array}{lllllll}4 & 16,7 & 17,1 & 576 & 180 & 69 & 194\end{array}$

$\begin{array}{lllllll}5 & 16,8 & 17,0 & 555 & 185 & 68 & 192\end{array}$

$\begin{array}{lllllll}16 & 16,3 & 16,4 & 474 & 183 & 68 & 163\end{array}$

$\begin{array}{lllllll}15 & 16,1 & 15,6 & 537 & 186 & 67 & 192\end{array}$

$\begin{array}{lllllll}3 & 16,0 & 15,6 & 572 & 183 & 67 & 200\end{array}$

$\begin{array}{lllllll}6 & 16,3 & 16,0 & 645 . & 186 & 66 & 224\end{array}$

$\begin{array}{lllllll}70 & 15,7 & 15,9 & 637 & 177 & 67 & 207\end{array}$

$\begin{array}{lllllll}6 & 16,1 & 15,9 & 521 & 186 & 67 & 183\end{array}$

$\begin{array}{lllllll}4 & 16,0 & 15,6 & 576 & 183 & 67 & 201\end{array}$

$\begin{array}{lllllll}15 & 16,4 & 16,3 & 621 & 186 & 67 & 216\end{array}$

$\begin{array}{lllllll}3 & 16,2 & 15,9 & 500 & 183 & 66 & 171\end{array}$

$\begin{array}{lllllll}48 & 15,8 & 16,0 & 636 & 177 & 66 & 204\end{array}$

$\begin{array}{lllllll}60 & 15,8 & 16,0 & 666 & 174 & 66 & 210\end{array}$

$\begin{array}{lllllll}32 & 16,4 & 16,2 & 631 & 183 & 66 & 214\end{array}$

$9 \quad 16,4 \quad 16,2 \quad 627 \quad 182 \quad 66 \quad 212$

$\begin{array}{lllllll}8 & 16,4 & 15,8 & 591 & 189 & 66 & 213\end{array}$

74 sфndenbro

$22 \quad 16,5 \quad 16,4 \quad 563 \quad 184 \quad 66 \quad 191$

75 Nyk $\phi$ bing

76 odden

$\begin{array}{lllllll}7 & 16,8 & 16,2 & 551 & 189 & 66 & 198\end{array}$

$\begin{array}{lllllll}9 & 16,8 & 16,7 & 626 & 184 & 67 & 216\end{array}$

$\begin{array}{lllllll}2 & 16,5 & 16,4 & 509 & 186 & 67 & 177\end{array}$ 
D e n mark (cont.)

\begin{tabular}{|c|c|c|c|c|c|c|c|c|}
\hline$N r$ & Station & $\begin{array}{c}\text { Alt. } \\
\text { m. }\end{array}$ & $\begin{array}{l}{ }^{\mathrm{T}} \mathrm{V} \\
{ }^{\circ} \mathrm{C}\end{array}$ & $\begin{array}{l}\mathrm{T}_{\mathrm{a}} \\
{ }^{\circ} \mathrm{C}\end{array}$ & $\begin{array}{c}\mathrm{N} \\
\mathrm{mm}\end{array}$ & $\begin{array}{c}\text { G } \\
\text { days }\end{array}$ & $\begin{array}{l}E \\
\%\end{array}$ & CVP \\
\hline 77 & Sejr $\varnothing$ Fyr & 4 & 16,3 & 16,1 & 428 & 186 & 67 & 150 \\
\hline 78 & Kys thospitalet & 3 & 17,2 & 17,1 & 420 & 186 & 67 & 146 \\
\hline 79 & s $\phi$ nders ted & 33 & 16,0 & 16,5 & 570 & 174 & 67 & 179 \\
\hline 80 & Frihedslund & 28 & 16,6 & 17,1 & 575 & 181 & 67 & 188 \\
\hline 81 & Tystofte & 13 & 16,7 & 16,8 & 522 & 183 & 66 & 174 \\
\hline 82 & Hindholm & 27 & 16,2 & 16,7 & 584 & 178 & 66 & 185 \\
\hline 83 & Ringsted & 55 & 16,5 & 17,2 & 622 & 175 & 67 & 194 \\
\hline 84 & Hasler & 50 & 16,6 & 16,7 & 640 & 177 & 66 & 206 \\
\hline 85 & $s \phi b \circ r g s$ & 3 & 16,5 & 17,0 & 585 & 177 & 67 & 187 \\
\hline 86 & Iille Dyrehavegaard & 40 & 16,6 & 17,3 & 659 & 179 & 67 & 211 \\
\hline 87 & Rungsted & 6 & 16,6 & 16,7 & 601 & 182 & 67 & 202 \\
\hline 88 & Landboh $\phi j s k o l e n$ & 13 & 17,0 & 17.3 & 579 & 183 & 67 & 194 \\
\hline 89 & Boserup Sanatorium & 13 & 16,2 & 16,6 & 539 & 177 & 67 & 173 \\
\hline 90 & Gjorslev & 20 & 16,6 & 16,8 & 555 & 192 & 66 & 193 \\
\hline 91 & Fakse & 50 & 16,3 & 17,1 & 598 & 177 & 66 & 185 \\
\hline 92 & Faksinge Sanatorium & 17 & 16,9 & 16,9 & 578 & 183 & 66 & 194 \\
\hline 93 & Salierup & 3 & 16,4 & 16,6 & 532 & 183 & 66 & 176 \\
\hline 94 & Vordingborg & 9 & 17,1 & 17,1 & 536 & 187 & 66 & 184 \\
\hline 95 & B०g $\phi$ & 27 & 16,4 & 16,4 & 573 & 183 & 66 & 192 \\
\hline 96 & Stege & 3 & 16,9 & 16,6 & 548 & 186 & 66 & 190 \\
\hline 97 & Mariebjerg & 9 & 16,4 & 16,0 & 591 & 186 & 66 & 207 \\
\hline 98 & $\operatorname{Iids} \phi$ & 1 & 16,7 & 16,7 & 567 & 183 & 66 & 190 \\
\hline 99 & Egholm & 3 & 16,4 & 16,6 & 551 & 183 & 66 & 183 \\
\hline 100 & Maribo & 16 & 16,8 & 16,7 & 653 & 186 & 66 & 224 \\
\hline 101 & Sфnder Alsler & 16 & 16,5 & 16,4 & 566 & 183 & 66 & 191 \\
\hline 102 & Gedser Fyr & 6 & 16,5 & 16,4 & 532 & 185 & 65 & 179 \\
\hline 103 & Hammershus & 15 & 16,3 & 16,1 & 549 & 180 & 66 & 183 \\
\hline 104 & Rønne & 10 & 16,5 & 16,5 & 539 & 180 & 66 & 178 \\
\hline 105 & Udenfor Almindingen & 116 & 15,8 & 17,1 & 651 & 1.71 & 66 & 189 \\
\hline 106 & Dueodde Fyr & 5 & $16, \dot{6}$ & 16,8 & 516 & 177 & 66 & 165 \\
\hline 107 & Christians $\phi$ & 6 & 16,3 & 16,0 & 419 & 179 & 66 & 140 \\
\hline
\end{tabular}


i n 1 a $n$ d

\begin{tabular}{|c|c|c|c|c|c|c|c|c|}
\hline $\mathrm{Nr}$ & Station & $\begin{array}{c}\text { Alt. } \\
\text { m. }\end{array}$ & $\begin{array}{l}\mathrm{T}_{\mathrm{v}} \\
{ }^{\circ} \mathrm{C}\end{array}$ & $\begin{array}{l}\mathrm{T}_{\mathrm{a}} \\
{ }^{\circ} \mathrm{C}\end{array}$ & $\begin{array}{c}\mathrm{N} \\
\mathrm{mm}\end{array}$ & $\begin{array}{c}G \\
\text { days }\end{array}$ & $\begin{array}{l}E \\
\%\end{array}$ & C VP \\
\hline 1 & Åbo (Turku) & 14 & 17,0 & 22,7 & 612 & 149 & 74 & 140 \\
\hline 2 & Mariehamn(Maarianhamina) & 1 & 15,6 & 19,0 & 558 & 143 & 73 & 1.33 \\
\hline 3 & Helsinki (Helsingfors) & 9 & 17,0 & 20,0 & 699 & 151 & 73 & 182 \\
\hline 4 & Lap peenranta (Villmans trand) & 108 & 17,4 & 25,9 & 653 & 141 & 75 & 129 \\
\hline 5 & Padasjoki & 110 & 17,0 & 25,0 & 541 & 136 & 75 & 104 \\
\hline 6 & Tampere(Tammerfors) & 84 & 16,8 & 23,8 & 628 & 141 & 75 & 130 \\
\hline 7 & Lavia & 40 & 16,6 & 24,6 & 567 & 134 & 76 & 108 \\
\hline 8 & Vilppula & 100 & 16,8 & 25,2 & 596 & 139 & 76 & 117 \\
\hline 9 & Jyväskylä & 109 & 16,2 & 24,7 & 638 & 134 & 77 & 120 \\
\hline 10 & Joensuu & 81 & 16,6 & 26,1 & 605 & 129 & 77 & 106 \\
\hline 11 & Kuopio & 110 & 16,4 & 25,9 & 618 & 132 & 78 & 112 \\
\hline 12 & Vasa (Vaasa) & 4 & 13,5 & 20,1 & 585 & 129 & 78 & 110 \\
\hline 13 & Haapavesi & 100 & 15,0 & 25,8 & 512 & 114 & 79 & 74 \\
\hline 14 & Kajaani & 140 & 15,0 & 25,6 & 627 & 118 & 80 & 96 \\
\hline 15 & Uleåborg (Oulu) & 2 & 15,7 & 25,7 & 545 & 120 & 81 & 90 \\
\hline 16 & Torneå (Tornio) & 10 & 15,2 & 27,0 & 495 & 108 & 82 & 69 \\
\hline 17 & Kuusamo & 266 & 13,6 & 26,3 & 606 & 102 & 82 & 73 \\
\hline 18 & Ylitornio & 3 & 15,7 & 28,0 & 549 & 117 & 83 & 83 \\
\hline 19 & Rovaniemi & 80 & 15,7 & 27,3 & 454 & 117 & 83 & 70 \\
\hline 20. & Salla (Aaliuki) & - & 15,5 & 27,7 & 450 & 111 & 84 & 65 \\
\hline 21 & Salla (Kuolajärvi) & - & 14,6 & 28,8 & 409 & 102 & 84 & 49 \\
\hline 22 & Sodankylä & 179 & 13,8 & 27,7 & 520 & 98 & 84 & 59 \\
\hline 23 & Muonio & 300 & 13,3 & 28,0 & 365 & 98 & 85 & 40 \\
\hline 24 & Pallasjärvi & - & 13,3 & 26,2 & 467 & 95 & 85 & 53 \\
\hline 25 & Laanila & - & 12,2 & 26,5 & 471 & 88 & 86 & 46 \\
\hline 26 & Enontäkiö & 440 & 13,3 & 28,2 & 405 & 90 & 86 & 47 \\
\hline 27 & Inari & 153 & 13,1 & 27,3 & 477 & 90 & 87 & 50 \\
\hline 28 & Ivalo & 134 & 12,8 & 26,0 & 467 & 89 & 86 & 49 \\
\hline 29 & Petsamo & 13 & 13,1 & 25,1 & 4.23 & 99 & 87 & 53 \\
\hline 30 & Vaitolahti & 4 & 11,1 & 17,5 & 450 & 89 & 88 & 62 \\
\hline 31 & Nuorgam(Neuvola) & 20 & 10,9 & 23,1 & 417 & 81 & 88 & 39 \\
\hline
\end{tabular}




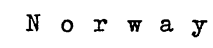

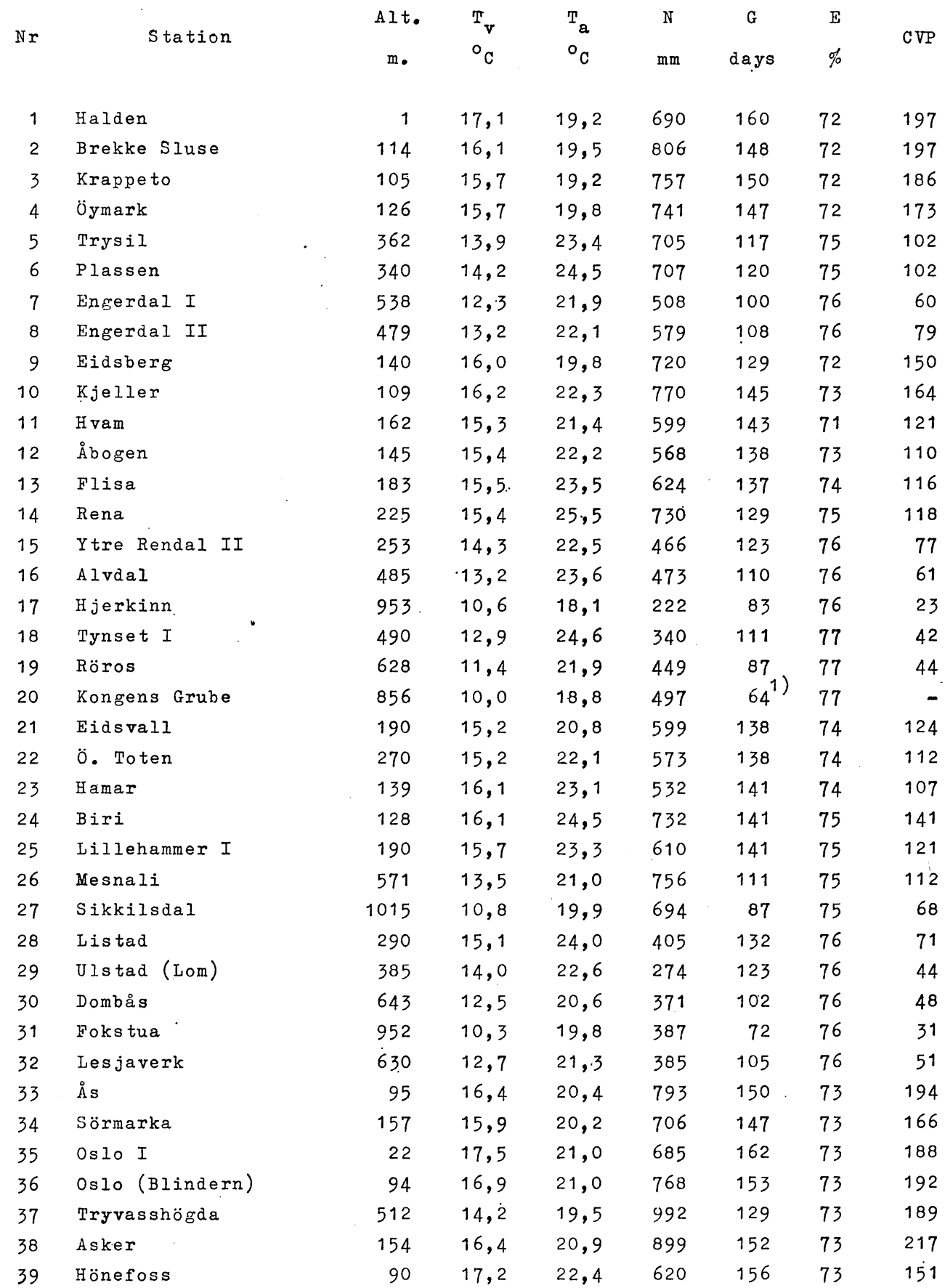

1) only 2 months with $+7^{\circ} \mathrm{C}$ 


\begin{tabular}{|c|c|c|c|c|c|c|c|c|}
\hline $\mathbb{N r}$ & Station & $\begin{array}{c}\text { Alt. } \\
\text { m.. }\end{array}$ & $\begin{array}{l}T_{\nabla} \\
{ }_{0} \\
\end{array}$ & $\begin{array}{l}\mathrm{T}_{\mathrm{a}} \\
{ }^{\circ} \mathrm{C}\end{array}$ & $\begin{array}{l}N \\
\mathrm{~mm}\end{array}$ & $\begin{array}{c}G \\
\text { days }\end{array}$ & $\begin{array}{l}E \\
\%\end{array}$ & C VP \\
\hline 40 & Kutjern & 4993 & 13,7 & 21,5 & 757 & 127 & 74 & 12.6 \\
\hline 41 & Tonsåsen & 631 & $.12,5$ & 21,2 & 802 & 115 & 74 & 112 \\
\hline 42 & Åbjörsbråten & 635 & 12,9 & 21,2 & 554 & 112 & 73 & 77 \\
\hline 43 & Vollen i Slidre & 403 & 14,1 & 23,7 & 574 & 123 & 75 & 88 \\
\hline 44 & V́ang i Valdres & 471 & 13,4 & 20,2 & 501 & 123 & 75 & 85 \\
\hline 45 & Modum I & 135 & 16,0 & 21,8 & 7.18 & 1.41 & 73 & 151 \\
\hline 46 & Nesbyen I & 1.64 & 15,4 & 25,4 & 453 & 135 & 74 & 76 \\
\hline 47 & Sveingården & .810 & 12,0 & 19,4 & 606 & 108 & 74 & 83 \\
\hline 48 & Geilo & 794 & 11,7 & 18,7 & 683 & 93 & 74 & 82 \\
\hline 49 & HangastöI II & 995 & 10,2 & 18,6 & 747 & $81^{2)}$ & 74 & - \\
\hline 50 & Slirå & 1300 & 6,7 & 15,7 & 1095 & $0^{3)}$ & 74 & - \\
\hline 51 & Horten & 15 & $1.6,7$ & 19,1 & 855 & 157 & 72 & 235 \\
\hline 52 & Kongsberg II & 155 & 15,6 & 21,5 & 801 & 143 & 73 & 169 \\
\hline 53 & Kn'w tehytta & 717 & 13,0 & 18,3 & 964 & 114 & 73 & 158 \\
\hline 54 & Veggli & 226 & 14,3 & 21,5 & 833 & 129 & 73 & 145 \\
\hline 55 & Dagali & 887 & 11,0 & 18,4 & 522 & 87 & 74 & 56 \\
\hline 56 & Skien & 28 & 16,3 & 20,9 & 787 & 156 & 72 & 192 \\
\hline 57 & Notodden & 22 & 16,9 & 22,0 & 759 & 153 & 72 & 178 \\
\hline 58 & Gnarv & 26 & $16 ; 3$ & 21,1 & 749 & 149 & 72 & 172 \\
\hline 59 & Dalen ị Telemark I & 102 & 16,2 & 19,8 & 876 & 150 & 72 & 215 \\
\hline 60 & Dalen i Telemark II & 77 & 15,9 & 19,7 & 831 & 147 & 72 & 197 \\
\hline 61 & Jömfruland & 15 & 16,8 & 17,8 & 860 & 164 & 73 & 270 \\
\hline 62 & Vefall i Drangedal & 68 & 16,1 & $2.0,0$ & 1011 & 156 & .72 & 254 \\
\hline 63 & Treitsund & 2.52 & 15,3 & 18,4 & 976 & 129 & 72 & 209 \\
\hline 64 & Grimstad II & 7. & 16,8 & 16,8 & 1184 & 178 & 71 & 416 \\
\hline 65 & Mykland & 265 & 15,7 & 18,3 & 1184 & 150 & 71 & 301 \\
\hline 66 & Kristiansand $\mathbf{s}$ & 22 & 16,2 & 16,6 & 1297 & 168 & 70 & 413 \\
\hline 67 & Heegeland & 174 & 15,0 & 18,0 & 1546 & 164 & 71 & 417 \\
\hline 68 & Byglandsfjord & 207 & 15,0 & 17,6 & 1269 & 147 & 71 & 314 \\
\hline 69 & Austad & 240 & 15,1 & 18,3 & 916 & 144 & 72 & 218 \\
\hline 70 & Mandal I & 6 & 15,8 & 15,6 & 1331 & 173 & 70 & 453 \\
\hline 71 & $\dot{B} j e l l a n d$ & 110 & 14,2 & 17,9 & 1386 & 138 & 71 & 299 \\
\hline 72 & Lịndesnes II & 10 & 14,4 & 13,5 & 843 & 174 & 70 & 304 \\
\hline 73 & Gardöl & 200 & 14,7 & 16,9 & 1417 & 149 & 71 & 362 \\
\hline 74 & Lista & 13 & 14,2 & 13,4 & 1050 & 171 & 7.0 & 370 \\
\hline 75 & Flekkef jord & 4 & 16,6 & 15,9 & 1768 & 173 & 70 & 562 \\
\hline
\end{tabular}
2) only 2 months with $+7^{\circ} \mathrm{C}$
3) no month with $+7^{\circ} \mathrm{C}$ 


$$
N \circ r w a y(\text { cont. })
$$

Nr Station

$\begin{array}{ccccccc}\text { Alt. } & \mathrm{T}_{\mathbf{v}} & \mathrm{T}_{\mathrm{a}} & \mathrm{N} & \mathrm{G} & \mathrm{E} & \\ \mathrm{m} . & { }^{\circ} \mathrm{C} & { }^{\circ} \mathrm{C} & \mathrm{mm} & \text { days } & \% & \end{array}$

76 Bakk

77 Tonstad

78 Vibberodden

79 Etkeland

80 Kvassheim

81 Obrestad

82 S tavanger

83 Sand i Ryfylke

84 Röldal

85 Svandalsflona

86 Sauda

8.7 Skudenes I

88 Slåtterög

89 Indre Matre

90 Ullensvang I

91 Eidfjord

92 Granvin

93 Syfteland

94 Bergen II

95 Bergsdal

96 Voss I

97 Raundal

98 Upsete

99 Eksingedal II

100 Hellisög Fyr

101 Vangsnes

102 Myrdal

103 Stondal

104 Lardal

105 Ijösne

106 Fortun

107 Fanaråken

108 Leikanger

109 Fjarland

110 Förde $i$ Sunnfjord

111 Florö

\begin{tabular}{|c|c|c|c|c|c|c|}
\hline 53 & 15,2 & 15,6 & 1800 & 161 & 71 & 557 \\
\hline 57 & 15,0 & 16,1 & 1697 & 159 & 71 & 496 \\
\hline 17 & 14,6 & 13,3 & 995 & 159 & 71 & 342 \\
\hline 250 & 14,4 & 14,6 & 2163 & $1 \dot{62}$ & 71 & 682 \\
\hline 7 & 13,7 & 12,5 & 1093 & 170 & 71 & 402 \\
\hline 24 & 13,5 & 12,3 & 1018 & 169 & 71 & 372 \\
\hline 67 & 14,1 & 12,5 & 1078 & 174 & 72 & 423 \\
\hline 2 & 14,4 & 14,0 & 2010 & 165 & 72 & 682 \\
\hline 430 & 13,5 & 17,6 & 1438 & 124 & 73 & 277 \\
\hline 1048 & 9,1 & 15,3 & 1175 & $-4)$ & 73 & - \\
\hline 5 & 14,4 & 16,1 & 2033 & 186 & 73 & 686 \\
\hline 2 & 14,0 & 11,9 & 1221 & 180 & 73 & 524 \\
\hline 15 & 13,5 & 11,4 & 1314 & 174 & 73 & 549 \\
\hline 24 & 13,9 & 12,7 & 2854 & 171 & 73 & 1083 \\
\hline 55 & 15,3 & $.15,2$ & 1634 & 159 & 74 & 538 \\
\hline 5 & 15,4 & 15,4 & 915 & 165 & 74 & 310 \\
\hline 345 & 13,8 & 16,9 & 1738 & 134 & 74 & 391 \\
\hline 55 & 13,9 & 14,2 & 2159 & $155^{\circ}$ & 73 & 664 \\
\hline 43 & 14,2 & 12,6 & 1944 & 174 & 74 & 784 \\
\hline 540 & 11,6 & 16,8 & 2201 & 108 & 74 & 337 \\
\hline 56 & 15,1 & 18,5 & 1376 & 153 & 74 & 353 \\
\hline 700 & 13,2 & 17,8 & 1454 & 120 & 74 & 266 \\
\hline 851 & 10,7 & 16,0 & 1557 & 84 & 74 & 180 \\
\hline 300 & 13,9 & 15,5 & 2328 & 136 & 74 & 584 \\
\hline 20 & 13,2 & 11,0 & 1237 & 169 & 74 & 516 \\
\hline 53 & 15,3 & 14,7 & 920 & 158 & 75 & 315 \\
\hline 870 & 10,1 & 15,5 & 1266 & 77 & 74 & 131 \\
\hline 657 & 11,6 & 16,3 & 743 & 99 & 74 & 108 \\
\hline 3 & 16,1 & 17,2 & 444 & 162 & 75 & 140 \\
\hline 107 & 16,5 & 17,9 & 375 & 165 & 75 & 119 \\
\hline 27 & 14,5 & 18,9 & 739 & 141 & 75 & 167 \\
\hline 2062 & 2,5 & 14,2 & 1261 & & 75 & - \\
\hline 22 & 15,7 & 15,6 & 937 & 165 & 75 & 324 \\
\hline 5 & 14,7 & 17,7 & 1670 & 141 & 75 & 407 \\
\hline 3 & 14,7 & 16,4 & 2171 & 155 & 75 & 628 \\
\hline 2 & 13,6 & 11,4 & 2161 & 168 & $\cdot 75$ & 902 \\
\hline
\end{tabular}

4) only 2 months with $+7^{\circ} \mathrm{C}$

5) no month with $+7^{\circ} \mathrm{C}$ 


$$
\text { Nor wa y (cont.) }
$$

\begin{tabular}{ll} 
Nr & \multicolumn{1}{c}{ Station } \\
& \\
112 & Stryn \\
113 & Opstryn \\
114 & Nordfjordeid \\
115 & Hellesylt \\
116 & Tafjord \\
117 & Alesund \\
118 & Andalsnes \\
119 & Molde II \\
120 & Sunndalsöra \\
121 & Sunndal \\
122 & Kristiansund I \\
123 & Vinjeöra \\
124 & Sandstad \\
125 & Berkåk \\
126 & Trondheim I \\
127 & Selbu \\
128 & Stugudal \\
129 & Meråker \\
130 & Stöp \\
131 & Sulstua \\
132 & Steinkjer \\
133 & Kjevli \\
134 & Snasa \\
135 & Vallersund \\
136 & Grong \\
137 & Nordli I \\
138 & Namsos \\
139 & Sörgjøslingan \\
140 & Rossvikvagen \\
141 & BrInnöysund I \\
142 & Skalvær \\
143 & Alstahaug \\
144 & Majavatu \\
145 & Hattfjelldal \\
146 & Rana \\
147 & Mo i Rana I \\
148 & Tonnes i Helgeland \\
149 & Myken \\
& \\
\hline 13
\end{tabular}

$\begin{array}{rcrrrrr}\text { Alt. } & \mathrm{T}_{\mathrm{v}} & \mathrm{T}_{\mathbf{g}} & \mathrm{N} & \mathrm{G} & \mathrm{E} & \mathrm{C} \mathrm{VP} \\ \mathrm{m} . & { }_{\mathrm{O}} \mathrm{C} & { }^{\mathrm{O}} \mathrm{C} & \mathrm{mm} & \text { days } & \% & \\ & & & & & & \\ 6 & 15,6 & 16,3 & 1110 & 156 & 76 & 350 \\ 205 & 14,5 & 15,2 & 991 & 150 & 76 & 299 \\ 71 & 14,4 & 14,7 & 1852 & 147 & 76 & 563 \\ 11 & 14,9 & 14,8 & 1624 & 153 & 76 & 528 \\ 27 & 14,8 & 13,6 & 837 & 169 & 77 & 329 \\ 6 & 13,2 & 10,7 & 1239 & 165 & 77 & 539 \\ 20 & 14,0 & 14,1 & 1269 & 152 & 77 & 410 \\ 50 & 14,2 & 14,1 & 1380 & 147 & 77 & 437 \\ 4 & 13,5 & 13,7 & 902 & 150 & 77 & 285 \\ 195 & 13,8 & 17,3 & 700 & 136 & 77 & 162 \\ 23 & 13,2 & 11,2 & 1271 & 162 & 78 & 526 \\ 15 & 13,8 & 15,7 & 1350 & 137 & 78 & 352 \\ 22 & 13,3 & 12,6 & 1187 & 147 & 79 & 404 \\ 424 & 12,4 & 18,3 & 647 & 103 & 78 & 98 \\ 58 & 14,2 & 16,2 & 764 & 141 & 79 & 207 \\ 197 & 13,9 & 17,5 & 795 & 132 & 78 & 181 \\ 615 & 11,4 & 18,4 & 652 & 96 & 78 & 84 \\ 218 & 13,6 & 17,9 & 849 & 123 & 79 & 174 \\ 40 & 14,6 & 17,9 & 681 & 138 & 79 & 168 \\ 251 & 13,1 & 19,0 & 939 & 114 & 79 & 162 \\ 5 & 15,0 & 18,6 & 732 & 141 & 79 & 183 \\ 195 & 13,6 & 19,2 & 876 & 103 & 80 & 142 \\ 141 & 14,4 & 18,7 & 874 & 110 & 80 & 165 \\ 4 & 13,3 & 13,0 & 912 & 147 & 79 & 301 \\ 72 & 14,0 & 18,4 & 1344 & 123 & 80 & 280 \\ 401 & 12,2 & 20,8 & 790 & 97 & 80 & 100 \\ 20 & 14,1 & 16,2 & 1178 & 168 & 80 & 383 \\ 6 & 12,9 & 12,2 & 879 & 144 & 81 & 301 \\ 13 & 13,0 & 13,1 & 1153 & 138 & 81 & 355 \\ 4 & 13,0 & 13,2 & 1086 & 138 & 82 & 336 \\ 4 & 12,6 & 12,4 & 880 & 131 & 82 & 267 \\ 8 & 13,7 & 14,6 & 1333 & 138 & 82 & 393 \\ 352 & 12,5 & 18,8 & 881 & 99 & 81 & 130 \\ 208 & 13,3 & 22,0 & 874 & 105 & 82 & 126 \\ 13 & 13,4 & 16,4 & 1320 & 120 & 83 & 298 \\ 8 & 13,8 & 19,6 & 1346 & 117 & 83 & 256 \\ 15 & 13,4 & 13,5 & 1030 & 135 & 83 & 318 \\ 19 & 12,2 & 11,5 & 857 & 126 & 84 & 267\end{array}$


$N \circ I * a y($ cont.)

\begin{tabular}{|c|c|c|c|c|c|c|c|c|}
\hline$N r$ & Station & $\begin{array}{c}\text { Alt. } \\
\text { m. }\end{array}$ & $\begin{array}{l}{ }^{T} \mathrm{v} \\
{ }^{\circ} \mathrm{C}\end{array}$ & $\begin{array}{l}\mathrm{T}_{\mathrm{a}} \\
{ }^{\circ} \mathrm{C}\end{array}$ & $\begin{array}{l}\mathrm{N} \\
\mathrm{mm}\end{array}$ & $\begin{array}{c}\text { G } \\
\text { days }\end{array}$ & $\begin{array}{l}\mathrm{E} \\
\%\end{array}$ & $\mathrm{CVP}$ \\
\hline 150 & Glomf jord & 39 & 12,8 & 13,7 & 1937 & 123 & 84 & 519 \\
\hline 151 & Fleinver & 4 & 12,1 & 11,8 & 945 & 126 & 84 & 285 \\
\hline 152 & Rognan & 28 & 12,7 & 18,7 & 714 & 111 & 84 & 126 \\
\hline 153 & Sulitjelma & 151 & 13,8 & 19,2 & 1040 & 114 & 84 & 199 \\
\hline 154 & Fauske & 15 & 13,2 & 16,1 & 987 & 117 & 84 & 221 \\
\hline 155 & Bodö I & 17 & 12,8 & 14,6 & 852 & 125 & 84 & 218 \\
\hline 156 & Grötöy & 5 & 13,0 & 13,5 & 868 & 117 & 85 & 231 \\
\hline 157 & Narvik & 32 & 13,5 & 16,9 & 645 & 114 & 86 & 140 \\
\hline 158 & Björnfjell & 512 & 11,0 & 21,5 & 749 & $69^{6)}$ & 86 & - \\
\hline 159 & Offersöy & 16 & 13,3 & 15,3 & 935 & 93 & 86 & 181 \\
\hline 160 & Sörvågen & 20 & 12,4 & 12,5 & 1493 & 117 & 85 & 409 \\
\hline 161 & Röst & 8 & 11,2 & 10,5 & 712 & 114 & 85 & 204 \\
\hline 162 & Eggum & 4 & 11,3 & 12,2 & 1143 & 112 & 86 & 283 \\
\hline 163 & Bö i Vesterålen & 7 & 12,0 & 13,6 & 993 & 114 & 86 & 239 \\
\hline 164 & Andenes & 5 & 10,7 & 12,5 & 808 & 99 & 87 & 165 \\
\hline 165 & Sandsöy $i$ Senja & 17 & 11,9 & 13,9 & 688 & 106 & 87 & 151 \\
\hline 166 & Gibostad & 6 & 12,1 & 16,0 & 748 & 100 & 87 & 137 \\
\hline 167 & Fagerlidal & 72 & 13,7 & 21,4 & 656 & 105 & 87 & 107 \\
\hline 168 & Dividalen & 226 & 13,5 & 22,5 & 296 & 99 & 87 & 42 \\
\hline 169 & Navaren & 5 & 12,5 & 18,7 & 903 & 101 & 87 & 147 \\
\hline 170 & Sommaröy i Senja & 2 & 11,1 & 13,2 & 651 & 102 & 88 & 136 \\
\hline 171 & Tromsö I & 45 & 11,6 & 15,4 & 1013 & 97 & 88 & 181 \\
\hline 172 & Tromsö II & 102 & 11,4 & 15,3 & 940 & 91 & 88 & 156 \\
\hline 173 & Torsvåg & 22 & 10,6 & 12,2 & 603 & 96 & 88 & 123 \\
\hline 174 & Loppa & 10 & 11,4 & 13,8 & 865 & 99 & 88 & 173 \\
\hline 175 & Alta & 14 & 12,8 & 20,7 & 298 & 102 & 88 & 46 \\
\hline 176 & Kau tokeino & 306 & 13,0 & 27,5 & 310 & 87 & 87 & 31 \\
\hline 177 & Sićdajavre & 382 & 12,5 & 27,4 & 322 & 81 & 86 & 28 \\
\hline 178 & Galten & 4 & 11,2 & 14,2 & 855 & 90 & 89 & 150 \\
\hline 179 & Hammerfest & 23 & 11,7 & 15,3 & 722 & 95 & 89 & 130 \\
\hline 180 & Ingöy & 4 & 9,4 & 12,0 & 641 & $75^{6)}$ & 89 & - \\
\hline 181 & Gjesveer & 5 & 10,6 & 14,5 & 763 & 90 & 89 & 124 \\
\hline 182 & Kistrand & 12 & 11,2 & 17,5 & 400 & 88 & 88 & 55 \\
\hline 183 & Lebesby & 10 & 11,6 & 18,2 & 506 & 84 & 89 & 67 \\
\hline 184 & Mehamn & 4 & 10,2 & 15,3 & 935 & $81^{6)}$ & 89 & - \\
\hline 185 & Tana II & 5 & 12,0 & 21,8 & 423 & 91 & 88 & 52 \\
\hline 186 & Karasjok & 129 & 13,2 & 27,9 & 316 & 93 & 87 & 34 \\
\hline 187 & Makkaur Fyr & 11 & 9,9 & 14,9 & 555 & $78^{6)}$ & 89 & - \\
\hline 188 & Vardö & 13 & 8,9 & 14,3 & 573 & $74^{6)}$ & 88 & - \\
\hline 189 & Ekkeröy & 7 & 10,2 & 16,8 & 361 & $81^{6)}$ & 88 & - \\
\hline 190 & Kirkenes & 5 & 12,1 & 22,1 & 402 & 90 & 88 & 48 \\
\hline
\end{tabular}

6) only 2 months with $+7^{\circ} \mathrm{C}$ 
S $w$ e d $n$

$\mathrm{Nr}$

5

6

7

8

9

10

11

12

13

14

15

16

17

18

19

20

21

22

23

24

25

26

27

28

29

30
Station

\section{Karesuando}

Riksgränsen

Abisko

Kiruna

Svappavara

Suorva

Junosuando

Gällivare

Merkenäs

Kvikkjokk

Porjus

Jokkmokk

Apua

Vuonatjviken

Nausta

Puottaure

Näsberg:

Åminne 3)

Morjärv

övertorneå

Tärnaby

Abborberg

Langrattnet

Stensele

Hedberg

Johannisberg

Malå

$S$ tormyrheden

Haraliden

Dalliden
$\begin{array}{ccccc}T_{v} & T_{a} & N & G & E \\ { }^{\circ} & { }_{C}{ }_{C} & m m & \text { days } & \%\end{array}$

CVP

$13,0 \quad 27,2 \quad 326$

$87 \quad 85$

$69^{1)} 84$

$10,6 \quad 21,1 \quad 844$

$81 \quad 84$

$21,9 \quad 267$

$12,0 \quad 23,9 \quad 453$

$81 \quad 84$

1022) 84

$25,2^{2)} \quad 418$

$\begin{array}{lll}11,8 & 22,6 & 404 \\ 14,2^{2)} & \left.27,6^{2}\right) & 405\end{array}$

$90 \quad 84$

$95^{2)} 84$

10284

$84 \quad 84$

$96 \quad 84$

$99 \quad 84$

105,83

$100^{2)} 84$

$84 \quad 83$

932) 83

1022) 83

$105^{2)} 83$

$120 \quad 82$

$114^{2)} 82$

11483

$120 \quad 82$

$121 \quad 81$

$127 \quad 81$

$132 \quad 81$

$103^{2)} 81$

$108 \quad 81$

$108 \quad 81$

$96 \quad 82$

$94^{2)} 81$

11181
32

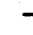

26

43

44

46

60

57

59

55

61

57

46

47

66

50

63

75

65

88

65

83

81

61

78

58

67

65

86

1) Only 2 months with $+7^{\circ} \mathrm{C}$

2) Interpolated value

3) Temperature values according to Hamberg (1908, p.24) pertain to the period 1859-1900. Precipitation values according to Wallén (1951) for the present weather station övre Svartlå. 
$S$ w $\operatorname{de} \mathrm{n}$ (cont.)

\begin{tabular}{|c|c|c|c|c|c|c|c|}
\hline $\mathrm{Nr}$ & Station & $\begin{array}{l}{ }^{\mathrm{T}}{ }_{\mathrm{v}} \\
{ }^{\circ} \mathrm{C}\end{array}$ & $\begin{array}{l}\mathrm{T}_{\mathrm{a}} \\
{ }^{\circ} \mathrm{C}\end{array}$ & $\begin{array}{c}\mathrm{N} \\
\mathrm{mm}\end{array}$ & $\begin{array}{c}G \\
\text { days }\end{array}$ & $\begin{array}{l}\mathrm{E} \\
\%\end{array}$ & CVP \\
\hline 31 & Piteå & 15,9 & 25,1 & 465 & 122 & 81 & 81 \\
\hline 32 & Högsön & 15,9 & 28,0 & 404 & 117 & 82 & 61 \\
\hline 33 & Haparanda & 15,6 & 26,9 & 533 & 114 & 82 & 80 \\
\hline 34 & Gäddede & 12,6 & 21,2 & 610 & 105 & 80 & 85 \\
\hline $35^{\circ}$ & Munsvattnet & 13,0 & 21,8 & 563 & 102 & 80 & 76 \\
\hline 36 & Storholmen & $14,2^{4)}$ & $25,6^{4)}$ & 519 & $123^{4)}$ & 80 & 79 \\
\hline 37 & Hoting & $15,2^{4)}$ & $25,9^{4)}$ & 521 & $129^{4)}$ & 80 & 88 \\
\hline 38 & Bjurfors & $13,6^{4)}$ & $25,0^{4)}$ & 474 & 1204) & 81 & 70 \\
\hline 39 & Svanmyren & $13,6^{4)}$ & $24,0^{4)}$ & 571 & $120^{4)}$ & 80 & 86 \\
\hline 40 & Viska ${ }^{5)}$ & 13,7 & 25,2 & 500 & 111 & 80 & 67 \\
\hline 41 & örträsk & $14,6^{4)}$ & $23,8^{4)}$ & 496 & $120^{4)}$ & 80 & 81 \\
\hline 42 & Sunnanå & $15,0^{4)}$ & $22,3^{4)}$ & 470 & $129^{4)}$ & 81 & 92 \\
\hline 43 & Bygdsiljum & $14,0^{4)}$ & $21,8^{4)}$ & 563 & $115^{4)}$ & 80 & 92 \\
\hline 44 & B jurökIubb & 14,8 & 22,0 & 425 & 120 & 80 & 76 \\
\hline 45 & Storlien & 11,2 & 18,2 & 915 & 67 & 78 & 82 \\
\hline 46 & Duved & 13,2 & 22,1 & 630 & 111. & 78 & 90 \\
\hline 47 & Östersund & 14,3 & 22,2 & 497 & 120 & 78 & 83 \\
\hline 48 & Gisselås & $14,8^{4)}$ & $2.4,0^{4)}$ & 506 & $114^{4)}$ & 79 & 78 \\
\hline 49 & Östra Junsele & 15,5 & 25,7 & $.550^{4)}$ & 123 & 79 & 90 \\
\hline 50 & Ramsele & $15,3^{4)}$ & $25,3^{4)}$ & 512 & $123^{4)}$ & 79 & 84 \\
\hline 51 & $\AA$ dalsliden & $15,8^{4)}$ & $25,5^{4)}$ & 522 & $127^{4)}$ & 79 & 90 \\
\hline 52 & Bispgården & 15,3 & 24,8 & 482 & 126 & 78 & 81 \\
\hline 53 & Tjälsbyn & $14,2^{4)}$ & $24,0^{4)}$ & 544 & $120^{4)}$ & 79 & 85 \\
\hline 54 & Skalmsjö & $14,8^{4)}$ & $23,3^{4)}$ & 568 & $123^{4)}$ & 79 & 97 \\
\hline 55 & Forse & 16,1 & 25,9 & 507 & 119 & 78 & 81 \\
\hline 56 & Kasa & 14,7 & 21,1 & 558 & 123 & 78 & 104 \\
\hline 57 & Nyåker & $15,7^{4)}$ & $23,9^{4)}$ & 560 & $120^{4)}$ & 79 & 96 \\
\hline 58 & Umeå & 15,6 & 23,0 & 564 & 123 & 79 & 103 \\
\hline 59 & Holmö Gadd & 14,6 & 19,4 & 419 & 120 & 79 & 83 \\
\hline 60 & Ljungdalen & $12,4^{4)}$ & $22 ; 6^{4)}$ & 559 & $101^{4)}$ & 78 & 67 \\
\hline 61 & Ljusnedal & 12,9 & 23,9 & 470 & 102 & 77 & 55 \\
\hline 62 & Storsätern & 12,1 & 22,5 & 568 & 93 & 76 & 60 \\
\hline 63 & Linsäli & $14,3^{4)}$ & $24,4^{4)}$ & 532 & $117^{4)}$ & 76 & 77 \\
\hline 64 & Norrböle & $\left.14,1^{4}\right)$ & $22,8^{4)}$ & 445 & $118^{4)}$ & 78 & 70 \\
\hline
\end{tabular}

4) Interpolated value

5) Temperature values according to Hamberg $(1908, p .24)$ pertain to the period 1859-1900. 
$S \pi$ ede $n$ (cont.)

$N r$

Station

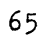

66

67

68

69

70

71

72

73

74

75

76

77

78

79

80

81

82

83

84

85

86

87

88

89

90

91

92

93

94

95

96

97

98

99

100

101
Tossåsen

Sveg

Boggsjö

Sösjö

Ånge

Ramsjö

Ljungå

Oxs jö

S töde

Gäddtjärnsåsen

Lagfors

Härnösand

Sidsjö.

Häljum

Brämö

Lungö

Storhögen

Särna

Nornäs

Ulvsjö

Lillhamra

Älvdalen

Los

Svedåsen

Bjuråker

Katrineberg

$\mathrm{S}$ trömsbruk

S torjungf run

Likenäs

Malung

Ekshärad

Knon

Johannisholm

Siljansfors

ํํㅇ

Rönndalen

Falun
$T_{v} \quad T_{a} \quad N$

${ }^{\circ} \mathrm{C}$

${ }^{\circ}$ mm

$14,5^{6)} \quad 23,5^{6)} \quad 350$

$14,7 \quad 24,6 \quad 512$

$13,9^{6)} \quad 23,9^{6)} \quad 552$

$13,5^{6)} \quad 23,5^{6)} \quad 592$

$15,6 \quad 25,5 \quad 451$

$14,7 \quad 25,0 \quad 469$

14,$8 ; \quad 24,6 \quad 507$

$14,5^{6)} \quad 22,2^{6)} \quad 476$

$15,5^{6)} \quad 24,5^{6)} \quad 602$

$13,4^{6)} \quad 23,6^{6)} \quad 635$

$15,0 . \quad 22,8 \quad 59.0$

$15,4 \quad 21,0 \quad 632$

$15,6,22,6 \quad 574$

$15,3^{6)} \quad 21,0^{6)} \quad 599$

$14,6 \quad 20,1 \quad 446$

$15,3.19,9 \quad 371$

$12,7^{6)} \quad 23,1^{6)} \quad 676$

$14,3 . \quad 25,6 \quad 562$

$13,9^{6)} \quad 24,7^{6)} \quad 594$

$13,3^{6)} \quad 23,1^{6)} \quad 728$

$14,4^{6)} \quad 23,6^{6)} \quad 702$

$15,5^{6)} \quad 23,5^{6)} \quad 600$

$\left.14,2^{6}\right) \quad 22,9^{6)} \quad 646$

$14,1^{6)} \quad 22,2^{6)} \quad 614$

$16,0 \quad 22,8 \quad 471$

$15,0^{6)} \quad 21,4^{6)} \quad 623$

$15,5^{6)} \quad 20,0^{6)} \quad 517$

$15,3 \quad 18,6 \quad 449$

$15,0 \quad 23,1 \quad 710$

$15,3 \quad 23,1 \quad 600$

$15,5 \quad 22,6 \quad 619$

$16,1,22,7,680$

$15,5^{6)} \quad 22,8^{6)} \quad 582$

$15,5 \quad 22,8 \quad 687$

$16,0^{6)} \quad 22,8^{6)} \quad 566$

$16,0^{6)} \quad 21,5^{6)} \quad 516$

16,8

$22,6 \quad 548$
$G$
days

119 $) \quad 78 \quad 56$

$12.1 \quad 76 \quad 78$

$114^{6)} 78$

$110^{6)} 78$

$129 \quad 77$

$120 \quad 76$

$120 \quad 77$

$118^{6)} 78$

1306) 77

1076) 77

$123 \quad 77$

$132 \quad 77$

$132 \quad 77$

1316) 77

$132 \quad 77$

$130 \quad 78$

$110^{6)} 75$

$117 \quad 76$

116 ) 75

1116) 75

1206) 75

1306) 75

$119^{6)} 75$

$116^{6)} 75$

$135 \quad 76$

1306) 75

$138^{6)} 76$

$138 \quad 75$

$132 \quad 74$

$129 \quad 74$

$138 \quad 73$

$144 \quad 73$

$131 \quad 74$

$132 \quad 74$

1376) 74

$138^{6)} 74$

$146 \quad 74$
C VP 56
78
79

76

70

78

79

106

83

102

131

112

122

91

80

85

78

81

97

107

107

99

94

94

118

117

106

125

105

1.19

141

107

127

112

109

122

6) Interpolated value 
$S$ w e d e n (cont.)

\begin{tabular}{|c|c|}
\hline $\mathrm{Nr}$ & Statior \\
\hline 102 & V. Svartnäs \\
\hline 103 & Botjärn \\
\hline 104 & stjärnsund \\
\hline 105 & Runhällen \\
\hline 106 & Hälsan \\
\hline 107 & Gävle \\
\hline 108 & Väsby \\
\hline 109 & Harg \\
\hline 110 & Understen \\
\hline 111 & Kölfors \\
\hline 112 & Adolfsfors \\
\hline 113 & Kyrkerud \\
\hline 114 & Noretjärn \\
\hline 115 & Kölen \\
\hline 116 & Forshult \\
\hline 117 & Rottneros \\
\hline 118 & Karlstad \\
\hline 119 & Malmbacka \\
\hline 120 & Ställdalen \\
\hline 121 & Gåsbernhyttan \\
\hline 122 & Filipstad \\
\hline 123 & Kedjeåsen \\
\hline 124 & Kloten \\
\hline 125 & Nyberget \\
\hline 126 & Färna \\
\hline 127 & Nora \\
\hline 128 & Björklund \\
\hline 129 & örebro \\
\hline 130 & Kävesta \\
\hline 131 & Högsjö \\
\hline 132 & Sätra brunn \\
\hline 133 & Väs terås \\
\hline 134 & Bie \\
\hline 135 & Uppsala \\
\hline 136 & Ultuna \\
\hline 137 & Hyvlinge \\
\hline 138 & UIvhäII \\
\hline
\end{tabular}

$\begin{array}{cccccc}\mathrm{T}_{\mathrm{v}} & \mathrm{T}_{\mathrm{a}} & \mathbb{N} & \mathrm{G} & \mathrm{E} & \mathrm{CVP} \\ { }^{\circ} \mathrm{C} & { }_{\mathrm{O}} & \mathrm{mm} & \text { days } & \% & \end{array}$

$14,7^{7)} \quad 20,7^{7)} \quad 602 \quad 135^{7)} \quad 75$

$15,4^{7)} \quad 20,2^{7)} \quad 634 \quad 137^{7)} \quad 75 \quad 138$

$\begin{array}{llllll}16,1 & 21,7 & 580 & 141 & 74 & 125\end{array}$

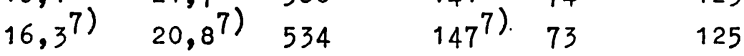

$\begin{array}{llllll}16,3 & 20,7 & 532 & 144 & 74 & 124\end{array}$

$\begin{array}{llllll}16,1 & 20,2 & 533 & 144 & 74 & 126\end{array}$

$\begin{array}{llllll}15,9 & 20,9 & 527 & .141 & 74 & 116\end{array}$

$\begin{array}{llllll}16,6 & 22,2 & 518 & 150 & 73 & 118\end{array}$

$15,2 \quad 16,8 \quad 411 \quad 141,73 \quad 106$

$14,6^{7)} \quad 19,3^{7)} \quad 750 \quad 150^{7)} \quad 7^{2} \quad 170$

$\begin{array}{llllll}16,2 & 22,1 & 645 & 144 & 73 & 138\end{array}$

$\begin{array}{llllll}15,8 & 20,3 & 714 & 145 & 72 & 161\end{array}$

$\left.16,3^{7)} \quad 21,1^{7)} \quad 607 \quad 1417\right) \quad 72 \quad 132$

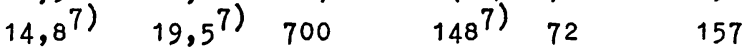

$\begin{array}{llllll}15,9 & 21,9 . & 706 & 141 & 73 & 147\end{array}$

$\begin{array}{llllll}16,7 & 21,1 & 577 & 153 & 73 & 142\end{array}$

$\begin{array}{llllll}17,3 & 20,5 & 631 & 159 & 72 & 169\end{array}$

$\left.14,4^{7)} \quad 21,1^{7)} \quad 771 \quad 1367\right) \cdot 73 \quad 145$

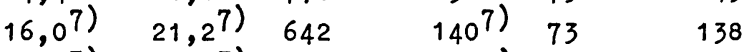

$15,5^{7)} \quad 21,3^{7)} \quad 755 \quad 138^{7)} \quad 73 \quad 154$

$\begin{array}{llllll}16,3 & 21,3 & 812 & 150 & 73 & 189\end{array}$

$\begin{array}{llllll}15,5 & 20,7 & 774 & 138 & 72 & 160\end{array}$

$\begin{array}{llllll}15,4 & 20,8 & 725 & 138 & 73 & 150\end{array}$

$15,7^{7)} \quad 20,3^{7)} \quad 703 \quad 144^{7)} \quad 73 \quad 159$

$\begin{array}{llllll}16,4 & 20,7 & 559 & 150 & 73 & 135\end{array}$

$\begin{array}{llllll}16,7 & 20,6 & 673 & 150 & 72 & 164\end{array}$

$16,7^{7)} \quad 20,0^{7)} \quad 658 \quad 155^{7)} \quad 72 \quad 170$

$\begin{array}{llllll}17,1 & 19,7 & 610 & 160 & 72 & 169\end{array}$

$17,0^{7)} \quad 19,7^{7)} \quad 555 \quad 159^{7)} \quad 72 \quad 152$

$\begin{array}{llllll}16,7 & 19,6 & 552 & 159 & 72 & 150\end{array}$

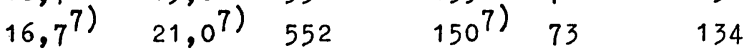

$17,3 \times 20,7 \quad 545 \quad 157 \quad 73 \quad 145$

$\begin{array}{llllll}17,0 & 21,0 & 599 & 153 & 72 & 148\end{array}$

$\begin{array}{llllll}16,9 & 20,7 & 545 & 153 & 73 & 138\end{array}$

$\begin{array}{llllll}16,5 & 20,4 & 516 & 150 & 73 & 127\end{array}$

16,8 7) $20,6^{7)} \quad 498 \quad 154^{7)} \quad 73 \quad 127$

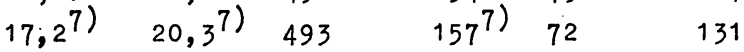

7) Interpolated value 
S we $d$ en (cont.)

\begin{tabular}{|c|c|c|c|c|c|c|c|}
\hline $\mathbb{N r}$ & Station & $\begin{array}{l}{ }_{\mathrm{v}} \\
{ }^{\circ} \mathrm{C}\end{array}$ & $\begin{array}{l}\mathrm{T}_{\mathrm{a}} \\
{ }^{\circ} \mathrm{C}\end{array}$ & $\begin{array}{c}\mathbb{N} \\
\mathrm{mm}\end{array}$ & $\begin{array}{c}\text { G } \\
\text { days }\end{array}$ & $\begin{array}{l}\mathrm{E} \\
\%\end{array}$ & CVP \\
\hline 139 & Södertälje & 17,0 & 20,0 & 558 & 156 & 72 & 148 \\
\hline 140 & Norr-Järsö & $15,8^{8)}$ & $18,9^{8)}$ & 468 & $150^{8)}$ & 73 & 119 \\
\hline 141 & Stockholm & 16,8 & 19,3 & 570 & 156 & 72 & 155 \\
\hline 142 & Ströms tad & 17,1 & 18,9 & 667 & 168 & 72 & 203 \\
\hline 143 & Väderöbod & 16,5 & 16,5 & 615 & 177 & 71 & 215 \\
\hline 144 & Hålı̈ & 16,6 & 17,0 & 583 & 177 & 71 & 199 \\
\hline 145 & Kristineberg & 16,8 & 17,6 & 817 & 174 & 70 & 264 \\
\hline 146 & Bråttkärr & $16,7^{8)}$ & $17,5^{8)}$ & 700 & $165^{8)}$ & 70 & 214 \\
\hline 147 & Måseskär & 16,5 & 16,8 & 521 & 174 & 70 & 173 \\
\hline 148 & Simmersröd & $17,1^{8)}$ & $18,2^{8)}$ & 758 & $174^{8)}$ & 70 & 241 \\
\hline 14.9. & Bäckefors & $15,7^{8)}$ & $19,2^{8)}$ & 798 & $158^{8)}$ & 71 & 203 \\
\hline 150 & Vänersborg & $16,8$. & 18,8 & 693 & 165 & 71 & 202 \\
\hline 151 & Koberg & 16,3 & 18,3 & 641 & 162 & 70 & 180 \\
\hline 152 & Vedum & 15,7 & 17,8 & 603 & 162 & 70 & 168 \\
\hline 153 & Sjötorp & 16,5 & 19,0 & 515 & 159 & 71 & 140 \\
\hline 154 & Hönsäter & 16,5 & 18,8 & 596 & 162 & 71 & 167 \\
\hline 155 & Skara & 15,7 & 18,5 & 582 & 153 & 71 & 149 \\
\hline 156 & Skövde & 16,2 & 18,6 & 661 & 159 & 71 & 181 \\
\hline 157 & Edsvära & $15,6^{8)}$ & $17,9^{8)}$ & 523 & $159^{8)}$ & 70 & 141 \\
\hline 158 & Askersund & 16,6 & 19,6 & 642 & 156 & 71 & 167 \\
\hline 159 & Sörbytorp & $16,1^{8)}$ & $19,7^{8)}$ & 714 & $153^{8)}$ & 71 & 176 \\
\hline 160 & Iindhult & $16 ; 0^{8)}$ & $19,0^{8)}$ & 655 & $152^{8)}$ & 71 & 165 \\
\hline 161 & Götlunda & 16,2 & 18,8 & 554 & 159 & 71 & 150 \\
\hline 162 & Spethult & $16,4^{8)}$ & $18,9^{8)}$ & 689 & $161^{8)}$ & 71 & 190 \\
\hline 163. & Drot.tningtorp & $14,8^{8)}$ & $18,5^{8)}$ & 556 & $142^{8)}$ & 70 & 123 \\
\hline 164 & S trömbäck & $15,5^{8)}$ & $17,7^{8)}$ & 566 & $156^{8)}$ & 70 & 150 \\
\hline 165 & Mariedam & $16,4^{8)}$ & $19,4^{8)}$ & 676 & $154^{8)}$ & 71 & 174 \\
\hline 166 & Finspång & 16,2 & 19,5 & 566 & 151 & 71 & 140 \\
\hline 167 & Grönkulla & $16,6^{8)}$ & $19,2^{8)}$ & 550 & $160^{8)}$ & 71 & 150 \\
\hline 168 & Halleby & $16,8^{8)}$ & $19,1^{8)}$ & 54.0 & $163^{8)}$ & 71 & 153 \\
\hline 169 & Linköping & 17,0 & 19,1 & 511 & 163 & 71 & 146 \\
\hline 170 & Adelsnäs & 16,1 & 19,3 & 530 & 153 & 70 & 132 \\
\hline 171 & Nyköping & 16,7 & 18,9 & 559 & 159 & 71 & 155 \\
\hline 172 & $\AA$ Ib erga & 16,8 & 19,9 & 553 & 156 & 71 & 144 \\
\hline 173 & övre Gränsö & 17,2 & 19,3 & 582 & 162 & 71 & 166 \\
\hline 174 & $\mathrm{H} \circ \mathrm{lmb} \circ$ & $17,1^{8)}$ & $19, i^{8)}$ & 567 & $160^{8)}$ & $70^{\circ}$ & 158 \\
\hline 175 & Landsort & 16,0 & 17,5 & 430 & 153 & 71 & 119 \\
\hline 176 & Gotska Sandön & 16,3 & 17,2 & 498 & 159 & .71 & 148 \\
\hline 177 & Vinga & 16,7 & 16,9 . & 654 & 183 & 70 & 230 \\
\hline
\end{tabular}

8) Interpolated value 
$S$ w e d e n (cont.)

\begin{tabular}{|c|c|}
\hline $\mathrm{Nr}$ & Station \\
\hline 178 & Kilanda \\
\hline 179 & Göteborg \\
\hline 180 & Borås \\
\hline 181 & Rydal \\
\hline 182 & Varberg \\
\hline 183 & Ulricehamn \\
\hline 184 & Tranhult \\
\hline 185 & Åstafors \\
\hline 186 & Kinnared \\
\hline 187 & Lommaryd \\
\hline 188 & Jönköping \\
\hline 189 & Flahult \\
\hline 190 & Prästkulla \\
\hline 191 & Gödeberg \\
\hline 192 & Iannaskede \\
\hline 1.93 & Värnamo \\
\hline 194 & Toraliden \\
\hline 195 & Hässleby \\
\hline 196 & Nyabyberg \\
\hline 197 & Kimramåla \\
\hline 198 & Ogestad \\
\hline 199 & Väs tervik \\
\hline 200 & Falsterbo bruk \\
\hline 201 & Sandbäckshult \\
\hline 2.02 & Ölands norra udde \\
\hline 203 & Tingstäde \\
\hline 204 & Visby \\
\hline 205 & Buttle \\
\hline 206 & östergarn \\
\hline 207 & Hemse \\
\hline 208 & Fårö \\
\hline 209 & Halms tad \\
\hline 210 & Hallands Väderö \\
\hline 211 & Båstad \\
\hline 212 & Kullen \\
\hline 213 & Lagan \\
\hline 214 & Strömsnäs \\
\hline
\end{tabular}

$\begin{array}{ccccc}\mathrm{T}_{\mathrm{V}} & \mathrm{T}_{\mathrm{a}} & \mathrm{N} & \mathrm{G} & \mathrm{E} \\ { }^{\circ} \mathrm{C} & { }^{\circ} \mathrm{C} & \mathrm{mm} & \text { days } & \%\end{array}$

CVP

$\begin{array}{llllll}15,7 & 17,4 & 796 & 165 & 70 & 230 \\ 17,2 & 17,5 & 738 & 195 & 70 & 275 \\ 15,9 & 18,3 & 903 & 159 & 70 & 243 \\ 16,39) & 18,19) & 898 & 1689) & 69 & 260 \\ 16,7 & 17,4 & 571 & 180 & 69 & 189\end{array}$

$14,9 \quad 18,0,799 \quad 147,70^{-} \quad 189$

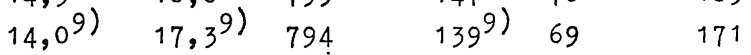

$\begin{array}{llllll}15,1 & 17,9 & 833 & 153 & 69 & 206\end{array}$

$\begin{array}{llllll}15,6 & 17,9 & 911 & 159 & 69 & 242\end{array}$

$\begin{array}{llllll}14,8 & 18,3 & 537 & 144 & 70 & 122\end{array}$

$\begin{array}{llllll}16,2 & 17,9 & 535 & 162 & 70 & 153\end{array}$

$14,8 \quad 18,2 \quad 673 \quad 145,70 \quad 154$

$14,9^{9)} \quad 18,5^{9)} \quad 567 \quad 146^{9)} 70 \quad 130$

$14,3^{9)} \quad 17,8^{9)} \quad 703 \quad 139^{9)} 70 \quad 153$

$15,8,18,9,643 \quad 153,69 \quad 158$

$16,0^{9)} \quad 18,2^{9)} \quad 652 \quad 157^{9)} \quad 69 \quad 172$

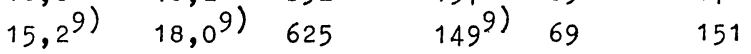

$\begin{array}{llllll}16,1 & 19,0 & 574 & 153 & 69 & 143\end{array}$

$15,7^{9)} \quad 18,7^{9)} \quad 573 \quad 153^{9)} \quad 69 \quad 141$

$\begin{array}{llllll}15,8 & 18,1 & 517 & 156 & 69 & 135\end{array}$

$\begin{array}{llllll}13,2 & 16,0 & 562 & 153 & 70 & 138\end{array}$

$16,9,18,3,548 \quad 164,69 \quad 159$

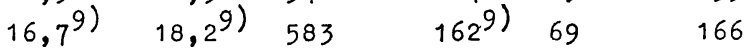

$\begin{array}{llllll}15,9 & 18,1 & 566 & 153 & 69 & 146\end{array}$

$\begin{array}{llllll}16,7 & 17,2 & 415 & 168 & 69 & 130\end{array}$

$\begin{array}{llllll}16,6 & 18,2 & 495 & 162 & 69 & 140\end{array}$

$\begin{array}{llllll}1.6,1 & 16,8 & 513 & 166 & 69 & 156\end{array}$

$\begin{array}{llllll}16,3 & 18,1 & 591 & 159 & 69 & 162\end{array}$

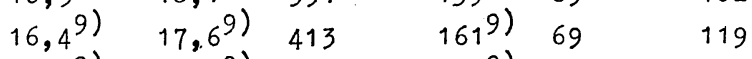

$16,2^{9)} \quad 17,5^{9)} \quad 535 \quad 160^{9)} 69 \quad 152$

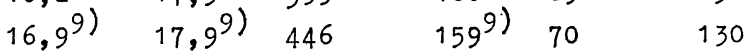

$\begin{array}{llllll}17,2 & 17,6 & 747 & 180 & 68 & 248\end{array}$

$\begin{array}{llllll}16,6 & 16,8 & 591 & 183 & 68 & 202\end{array}$

$\begin{array}{llllll}16,8 & 17,5 & 764 & 177 & 68 & 245\end{array}$

$\begin{array}{llllll}16,2 & 16,5 & 590 & 177 & 68 & 194\end{array}$

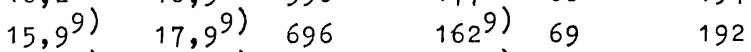

$\begin{array}{llllll}14,8^{9} & 16,4^{9)} & 812 & \left.161^{9}\right) & 68 & 223\end{array}$

9) Interpolated value 


$$
\text { S we de n (cont.) }
$$

Nr Station

215 Knäred

216 Kolleberga

217 Växjö

218 Ekefors

219 Osby

220 Mjönäs

221 Kristianstad

222 Karlshamn

223 Hoby

224 Ronneby

225 Kungsholmen

226 Borgholm

227 Kalmar

228 ölvingstorp

229 Mörbylånga

230 ölands södra udde

231 Hoburg

232 Malmö

233 Falsterbo

234 ÄImhult

235 Iund

236 Svedala

237 Ystad

238 Bollerup
$\begin{array}{cccccc}\mathrm{T}_{\mathrm{v}} & \mathrm{T}_{\mathrm{a}} & \mathrm{N} & \mathrm{G} & \mathrm{E} & \mathrm{CVP} \\ { }^{\circ} \mathrm{C} & { }^{\circ} \mathrm{C} & \mathrm{mm} & \text { days } & \% & \end{array}$

$\begin{array}{llllll}15,6 & 17,3 & 791 & 162 & 68 & 218\end{array}$

$16,1^{10)} \quad 17,2^{10)} 749 \quad 169^{10)} \cdot 67 \quad 221$

$\begin{array}{llllll}16,6 & 18,6 & 593 & 162 & 69 & 164\end{array}$

$15,7 \quad 18,1,639 \quad 159,68 \quad 166$

$16,0^{10)} 17,2^{10)} 690 \quad 168^{10)} 68 \quad 204$

$16,2^{10)} \quad 17,4^{10)} 646 \quad 173^{10)} 68 \quad 197$

$\begin{array}{llllll}16,9 & 17,2 & 551 & 177 & 67 & 178\end{array}$

$\begin{array}{llllll}16,8 & 17,4 & 562 & 174 & 68 & 178\end{array}$

$16,3^{10)} 17,6^{10)} 552 \quad 168^{10)} 68 \quad 162$

$\begin{array}{llllll}16,3 & 17,4 & 575 & 171 & 68 & 174\end{array}$

$\begin{array}{llllll}16,8 & 17,3 & 511 & 1.71 & 68 & 160\end{array}$

$16,4^{10)} 17,4^{10)} 466 \quad 173^{10)} 69 \quad 146$

$16,617,1,465 \quad 175,68 \quad 149$

$16,4^{10)} \quad 17,7^{10)} 517 \quad 174^{10)} 68 \quad 157$

$16,7,18,5,441 \quad 162,68 \quad 122$

$17,2^{10)} 18,4^{10)} 414 \quad 165^{10)} 68 \quad 121$

$\begin{array}{llllll}15,9 & 16,6 & 423 & 162 & 69 & 126\end{array}$

$\begin{array}{llllll}16,6 & 16,8 & 526 & 180 & 67 & 174\end{array}$

$16,6,16,4,443 \quad 183,67 \quad 153$

$15,7^{10)} \quad 16,9^{10)} 792 \quad 167^{10)} 67 \quad 229$

$\begin{array}{llllll}16,5 & 17,1 & 616 & 177 & 67 & 196\end{array}$

$\begin{array}{llllll}16,3 & 17,1 & 558 & 177 & 67 & 175\end{array}$

$\begin{array}{llllll}16,1 & 16,1 & 564 & 180 & 67 & 189\end{array}$

$\begin{array}{llllll}16,8 & 17,6 & 581 & 174 & 67 & 180\end{array}$

10) Interpolated value 
Table III. Yield, climate data and CVP-index of forest sample plots in the Nordic countries

$D$ e $n$ m a $r k$

\begin{tabular}{|c|c|c|c|c|c|c|c|c|c|c|c|c|c|}
\hline \multirow{2}{*}{$\begin{array}{c}\text { Tree } \\
\text { species }\end{array}$} & \multirow[t]{2}{*}{ Sample } & \multicolumn{2}{|c|}{ plot } & \multirow{2}{*}{$\begin{array}{l}\text { Annual mean } \\
\text { increment } \\
\mathrm{m}^{3} / \text { hectare }\end{array}$} & \multicolumn{2}{|c|}{ Station } & \multicolumn{5}{|c|}{$\begin{array}{l}\text { Corrected climatic values } \\
\text { of the sample plot }\end{array}$} & \multirow[b]{2}{*}{ CVP } & \multirow[b]{2}{*}{$C \mathrm{CP}_{1}$} \\
\hline & & age & $\begin{array}{l}\text { alt. } \\
\text { m. }\end{array}$ & & $\mathrm{nr}$ & $\begin{array}{l}\text { alt. } \\
\text { m. }\end{array}$ & $\begin{array}{l}{ }_{\mathrm{v}}^{\mathrm{T}} \\
{ }^{\mathrm{o}} \mathrm{C}\end{array}$ & $\begin{array}{l}\mathrm{T}_{\mathrm{a}} \\
{ }^{\circ} \mathrm{C}\end{array}$ & $\mathrm{N}$ & $\begin{array}{c}G \\
\text { days }\end{array}$ & $\begin{array}{l}E \\
\%\end{array}$ & & \\
\hline Picea & $I Q$ & 46 & 30 & 16,7 & 86 & 40 & 16,5 & 17,2 & 659 & 178 & 67 & 209 & 8,14 \\
\hline \multirow[t]{5}{*}{ excelsa } & IO & 48 & 60 & 10,4 & 31 & 65 & 15,6 & 15,7 & 733 & 176 & 67 & 239 & 8,83 \\
\hline & IT & 50 & 60 & 20,9 & 69 & 60 & 15,8 & 16,0 & 666 & 174 & 66 & 210 & 8,14 \\
\hline & $G G$ & 52 & 65 & 10,7 & 43 & 60 & 15,1 & 15,9 & 695 & 170 & 67 & 209 & 7,93 \\
\hline & IV & 52 & 25 & 14,4 & 38 & 42 & 15,8 & 16,0 & 583 & 176 & 68 & 191 & 7,91 \\
\hline & IS & 65 & 70 & 4,9 & 43 & 60 & 15,0 & 15,8 & 695 & 168 & 67 & 206 & 7,81 \\
\hline Picea & GM & 35 & 110 & 17,1 & 84 & 50 & 16,2 & 16,5 & 640 & 169 & 66 & 19.5 & 7,71 \\
\hline sitchen- & MB & 47 & 45 & 23,2 & 9 & 12 & 15,3 & 15,4 & 716 & 174 & 69 & 237 & 8,86 \\
\hline \multirow[t]{3}{*}{ sis } & ID & 51 & 40 & 21,2 & 83 & 55 & 16,6 & 17,2 & 622 & 177 & 67 & 198 & 7,94 \\
\hline & $\mathrm{ME}$ & 62 & 5 & 24,3 & 50 & 5 & 16,0 & 16,3 & 583 & 174 & 68 & 188 & 7,79 \\
\hline & GU & 69 & 90 & 12,6 & 43 & 60 & 15,0 & 15,8 & 695 & 168 & 67 & 206 & 7,81 \\
\hline Abies & GR & 44 & 85 & 20,2 & 40 & 71 & 15,1 & 15,7 & 650 & 169 & 68 & 200 & 7,84 \\
\hline grandis & IR & 44 & 45 & 25,3 & 51 & 40 & 15,5 & 15,3 & 740 & 179 & 66 & 246 & 9,04 \\
\hline \multirow{2}{*}{$\begin{array}{l}\text { Larix } \\
\text { leptole- } \\
\text { pis }\end{array}$} & GO & 45 & 50 & 13,6 & 40 & 71 & 15,3 & 15,7 & 650 & 174 & $6 \dot{8}$ & 208 & 8,16 \\
\hline & GV & 52 & 40 & 13,9 & 51 & 40 & 15,5 & 15,3 & 740 & 180 & 66 & 247 & 9,08 \\
\hline
\end{tabular}

Temperature observed during 40 years, $1886-1925$.

Termometer position $1,3-2,0 \mathrm{~m}$ above the ground; times of observation:

8 A.M., 2 P.M. and 21 P.M.

Before publication the simple arithmetic means obtained from these observations have been corrected to "true means" by considering the minimum night temperature. (Climate of Denmark, 1933, p.226) The rain gauge placed approx. $1,5 \mathrm{~m}$ above the ground, no snow (or rain) screen (ibid., p. 228). 
$\mathrm{F} \perp \mathrm{n} I$ a $\mathrm{n}$ d

\begin{tabular}{|c|c|c|c|c|c|c|c|c|c|c|c|}
\hline & aple & & Annual mean & Sta & tioio & $\begin{array}{r}\text { Corre } \\
\text { of }\end{array}$ & $\begin{array}{l}\text { ctei } c \\
\text { the s }\end{array}$ & Iima & $\begin{array}{l}\text { ic va } \\
\text { plot }\end{array}$ & Iues & \\
\hline$n r$ & age & alt. & increment & $n r$ & & $\mathrm{~T}_{\mathrm{v}}$ & $\mathrm{T}_{\mathrm{a}}$ & $N$ & $G$ & $E$ & $C V P C V P$ \\
\hline & & & & & $\mathrm{m}$. & ${ }^{\circ} \mathrm{C}$ & ${ }^{\circ} \mathrm{C}$ & $\mathrm{mm}$ & days & $\%$ & \\
\hline $13^{1)}$ & 70 & 120 & 6,3 & 5 & 110 & 16,9 & 24,9 & 541 & 135 & 75 & 1034,43 \\
\hline $15^{2)}$ & 70 & 120 & 5,4 & 5 & 1.10 & 16,9 & 24,9 & 541 & 135 & 75 & 1034,43 \\
\hline $266^{3)}$ & 76 & 110 & 6,8 & 5 & 110 & 17,0 & 25,0 & 541 & 136 & 75 & 1044,47 \\
\hline $14^{4)}$ & 90 & 120 & 5,1 & 5 & 110 & 16,9 & 24,9 & 541 & 135 & 75 & 1034,43 \\
\hline $3 a^{5)}$ & 84 & 50 & 1,7 & 7 & 40 & 15,9 & 23,3 & 567 & 132 & 76 & $108 \quad 4,54$ \\
\hline $1 a^{5)}$ & 95 & 50 & 1,9 & 7 & 40 & $15,9^{\circ}$ & 23,3 & 567 & 132 & 76 & 1084,54 \\
\hline $9 c^{5)}$ & 105 & 50 & 1,9 & 7 & 40 & 15,9 & 23,3 & 567 & 132 & 76 & 1084,54 \\
\hline $7 a^{5)}$ & 119 & 50 & 2,0 & 7 & 40 & 15,9 & 23,3 & 567 & 132 & 76 & 1084,54 \\
\hline $25 a^{6)}$ & 61 & 110 & 7,6 & 8 & 100 & 16,7 & 25,2 & 596 & 138 & 76 & 1154,71 \\
\hline $15 a^{7)}$ & 86 & 110 & 7,3 & 8 & 100 & 16,7 & 25,2 & 596 & 138 & 76 & 1154,71 \\
\hline 208) & 102 & 180 & 5,2 & 8 & 100 & 16,3 & 25,0 & 596 & 134 & 76 & 1104,51 \\
\hline $21^{9)}$ & 111 & 140 & 6,4 & 8 & 100 & 16,6 & 25,1 & 596 & 136 & 76 & 1134,63 \\
\hline $1^{5)}$ & 100 & 120 & 3,8 & 19 & 80 & 15,5 & 27,1 & 454 & 113 & 83 & 683,19 \\
\hline $2 a^{5)}$ & 100 & 120 & 3,2 & 19 & 80 & 15,5 & 27,1 & 454 & 113 & 83 & 683,19 \\
\hline
\end{tabular}
1) birch only
2)birch - $76 \%$
3) spruce - $54 \%$
4)pine $\quad-13 \%$ spruce \& pine $-24 \%$ birch $-46 \%$ spruce $-87 \%$
5)pine oniy
6)birch - $50 . \%$ pine $-47 \%$ spruce - $3 \%$
7) pine - $94 \%$ birch - $6 \%$
8) spruce $-76 \%$ birch $-24 \%$

9)pine - $92 \%$ spruce - $8 \%$

The data of the notes concerning the composition of the stand refer to the numerical distribution and not to the share of each tree species of the total annual mean increment what is the case with the Swedish material. 


\section{$N \circ r$ a $y$}

\begin{tabular}{|c|c|c|c|c|c|c|c|c|c|c|c|c|}
\hline \multirow[b]{2}{*}{$\mathrm{nr}$} & \multirow{2}{*}{$\begin{array}{c}\text { Sample } \\
\text { age }\end{array}$} & $10 t$ & \multirow{2}{*}{$\begin{array}{l}\text { Annual mean } \\
\text { increment } \\
m^{3} / \text { hectare }\end{array}$} & \multicolumn{2}{|c|}{ Station } & \multicolumn{5}{|c|}{ of the sample plot } & \multirow[b]{2}{*}{$\mathrm{CVP}$} & \multirow[b]{2}{*}{$\mathrm{CVP}_{1}$} \\
\hline & & $\underset{\mathrm{m}}{\mathrm{a} \mathrm{t}_{\bullet}}$ & & $\mathrm{nr}$ & alt. & $\begin{array}{l}\mathrm{T}_{\mathrm{v}} \\
{ }^{\circ} \mathrm{C}\end{array}$ & $\begin{array}{l}\mathrm{T}_{\mathrm{a}} \\
{ }^{\circ} \mathrm{C}\end{array}$ & $\begin{array}{l}\mathbb{N} \\
\min \end{array}$ & $\begin{array}{c}\text { G } \\
\text { days }\end{array}$ & $\%$ & & \\
\hline 89 & 81 & 130 & 4,3 & 70 & 6 & 15,0 & 15,3 & 1331 & 159 & 70 & 403 & 11,05 \\
\hline 80 & 85 & 90 & 3,4 & 70 & 6 & 15,3 & 15,4 & 1331 & 162 & 70 & 417 & 11,43 \\
\hline 63 & 81 & 200 & 5,8 & 72 & 10 & 13,5 & 14,5 & 843 & 156 & 70 & 238 & 8,20 \\
\hline 97 & 86 & 120 & 2,7 & 66 & 22 & 15,6 & 16,4 & 1297 & 157 & 70 & 377 & 10,47 \\
\hline 98 & 108 & 80 & 4,0 & 66 & 22 & 15,8 & 16,4 & 1297 & 161 & 70 & 391 & 10,86 \\
\hline 96 & 80 & 90 & 4,4 & 66 & 22 & 15,8 & 16,5 & 1297 & 159 & 70 & 384 & 10,66 \\
\hline 101 & 93 & 30 & 4,9 & 64 & 7 & 16,7 & 16,8 & 1184 & 175 & 71 & 406 & 11,80 \\
\hline 99 & 87 & 50 & 3,6 & 64 & 7 & 16,6 & 16,8 & 1184 & 173 & 71 & 399 & 11,60 \\
\hline 100 & 96 & 50 & 4,4 & 64 & 7 & 16,6 & 16,8 & 1184 & 173 & 71 & 399 & 11,60 \\
\hline 77 & 80 & 110 & 3,2 & 66 & 22 & 16,8 & 18,1 & 1297 & 157 & 70 & 368 & 10,33 \\
\hline 95 & 80 & 240 & 4,4 & 67 & 174 & 14,6 & 17,9 & 1546 & 160 & 71 & 398 & 10,12 \\
\hline 94 & 81 & 230 & 4,9 & 67 & 174 & 14,7 & 18,0 & 1546 & 160 & 71 & 398 & 10,12 \\
\hline 85 & 82 & 90 & 3,0 & 71 & 110 & 14,3 & 17,9 & 1386 & 140 & 71 & 306 & 8,22 \\
\hline 74 & 86 & 200 & 2,9 & 71 & 110 & 13,7 & 17,8 & 1386 & 132 & 71 & 278 & 7,47 \\
\hline 58 & 99 & 190 & 4,0 & 67 & 174 & 14,9 & 18,0 & 1546 & 163 & 71 & 411 & 10,45 \\
\hline 50 & 94 & 190 & 2,0 & 67 & 174 & 14.9 & 18,0 & 1546 & 163 & 71 & 411 & 10,45 \\
\hline 70 & 90 & 200 & 3,4 & 67 & 174 & 14,8 & 17,7 & 1546 & 162 & 71 & 413 & 10,50 \\
\hline 71 & 80 & 360 & 2,8 & 68 & 207 & 14,0 & 17,2 & 1269 & 138 & 71 & 281 & 7,89 \\
\hline 44 & 84 & 150 & 4,7 & 63 & $252^{\circ}$ & 15,9 & 18,6 & 976 & 136 & 72 & 227 & 7,27 \\
\hline 52 & 88 & 230 & 2,8 & 69 & 240 & 15,2 & 18,4 & 916 & 145 & 72 & 219 & 7,24 \\
\hline 62 & 85 & 365 & 6,8 & 69 & 240 & 14,3 & 18,0 & 916 & 137 & 72 & 199 & 6,58 \\
\hline 60 & 104 & 700 & 1,2 & 69 & 240 & 12,3 & 17,4 & 916 & 122 & 72 & 158 & 5,22 \\
\hline 38 & 114 & 300 & 2,6 & 59 & 102 & 15,0 & 19,5 & 876 & 137 & 72 & 185 & 6,25 \\
\hline 35 & 110 & 300 & 4,1 & 59 & 102 & 15,0 & 19,5 & 876 & 137 & 72 & 185 & 6,25 \\
\hline 37 & 108 & 300 & 2,6 & 59 & 102 & 15,0 & 19,5 & 876 & 137 & 72 & 185 & 6,25 \\
\hline 41 & 84 & 300 & 2,5 & 59 & 102 & 15,0 & 19,5 & 876 & 137 & 72 & 185 & 6,25 \\
\hline 34 & 111 & 325 & 5,3 & 59 & 102 & 14,8 & 19,4 & 876 & 136 & 72 & 182 & 6,15 \\
\hline 29 & 83 & 600 & 3,6 & 46 & 164 & 12,8 & 24,5 & 453 & 112 & 74 & 54 & 2,54 \\
\hline 30 & 101 & 350 & 1,7 & 46 & 164 & 14,3 & 25,0 & 453 & 123 & 74 & 66 & 3,10 \\
\hline 33 & 86 & 405 & 5,0 & 46 & 164 & 13,5 & 22,5 & 630 & 124 & 73 & 95 & 3,78 \\
\hline 109 & 110 & 280 & 3,4 & 12 & 145 & 14,6 & 21,9 & 568 & 129 & 74 & 100 & 4,20 \\
\hline 106 & 93 & 370 & 4,8 & 12 & 145 & 14,0 & 21,8 & 568 & 124 & 74 & 93 & 3,90 \\
\hline 108 & 93 & 400 & 3,1 & 12 & 145 & 13,8 & $.21,7$ & 568 & 123 & 74 & 91 & 3,82 \\
\hline 104 & 110 & 230 & 3,2 & 12 & 145 & 14,9 & 22,0 & 568 & 132 & 74 & 104 & 4,36 \\
\hline 102 & 93 & 280 & 1,5 & 12 & 145 & 14,6 & 21,9 & 568 & 129 & 74 & 100 & 4,20 \\
\hline 107 & 95 & 370 & 3,2 & 12 & 145 & 14,0 & 21,8 & 568 & 124 & 74 & 93 & 3,90 \\
\hline 103 & 112 & 240 & 2,3 & 1.2 & 145 & 14,8 & 21,9 & 568 & 132 & 74 & 104 & 4,36 \\
\hline
\end{tabular}




$$
\text { Norway (cont.) }
$$

\begin{tabular}{|c|c|c|c|c|c|c|c|c|c|c|c|c|}
\hline \multicolumn{3}{|c|}{ Sample plot } & \multirow{2}{*}{$\begin{array}{l}\text { Annual mean } \\
\text { increment } \\
\mathrm{m}^{3} / \text { hectare }\end{array}$} & \multicolumn{2}{|c|}{ Station } & \multicolumn{5}{|c|}{$\begin{array}{l}\text { Corrected climatic values } \\
\text { of the sample plot }\end{array}$} & \multirow[b]{2}{*}{ CVP. } & \multirow[b]{2}{*}{$\mathrm{CVP}_{1}$} \\
\hline $\mathrm{nr}$ & age & $\begin{array}{c}\text { alt. } \\
\text { m. }\end{array}$ & & $n r$ & $\begin{array}{c}\text { alt. } \\
\text { m. }\end{array}$ & $\begin{array}{l}\mathrm{T}_{\mathrm{v}} \\
{ }^{\circ} \mathrm{C}\end{array}$ & $\begin{array}{l}\mathrm{T}_{\mathrm{a}} \\
{ }^{\circ} \mathrm{C}\end{array}$ & $\begin{array}{c}\mathrm{N} \\
\mathrm{mm}\end{array}$ & $\begin{array}{c}G \\
\text { days }\end{array}$ & $\begin{array}{l}\mathrm{E} \\
\%\end{array}$ & & \\
\hline 110 & 108 & 200 & 3,9 & 13 & 183 & 15,4 & 23,5 & 624 & 136 & 74 & 114 & 4,56 \\
\hline 111 & 86 & 200 & 3,8 & 13 & 183 & 15,4 & 23,5 & 624 & 136 & 74 & 114 & 4,56 \\
\hline 112 & 104 & 200 & 4,7 & 13 & 183 & 15,4 & 23,5 & 624 & 136 & 74 & 114 & 4,56 \\
\hline 113 & 104 & 200 & 2,7 & 13 & 183 & 15,4 & 23,5 & 624 & 136 & 74 & 114 & 4,56 \\
\hline $7^{\text {III }}$ & 101 & 250 & 3,6 & 14 & 225 & 15,2 & 25,4 & 730 & 127 & 75 & 116 & 4,29 \\
\hline $7^{I V}$ & 101 & 250 & 4,2 & 14 & 225 & $1.5,2$ & 25,4 & 730 & 127 & 75 & 116 & 4,29 \\
\hline 10 & 93 & 440 & 1,8 & $81 \mathrm{~Sv}$ & 600 & 13,7 & 23,5 & 676 & 1.17 & 75 & 96 & 3,69 \\
\hline 11 & 120 & 460 & 2,9 & $81 \mathrm{SV}$ & 600 & 13,5 & 23,3 & 676 & 116 & 75 & 95 & 3,65 \\
\hline 12 & 103 & 360 & 1,8 & $81 \mathrm{SV}$ & 600 & 14,1 & 23,4 & 676 & 121 & 75 & 103 & 3,96 \\
\hline 13 & 105 & 400 & 2,1 & $815 v$ & 600 & 13,9 & 23,4 & 676 & 119 & 75 & 100 & 3,85 \\
\hline 8 & 117 & 410 & 2,6 & 5 & 362 & 13,6 & 23,3 & 705 & 115 & 75 & 99 & 3,73 \\
\hline 9 & 118 & 570 & 2,5 & 5 & 362 & 12,6 & 23,0 & 705 & 107 & 75 & 86 & 3,24 \\
\hline 2 & 95 & 560 & 1,7 & 7 & 538 & 12,2 & 21,9 & 508 & 99 & 75 & 58 & 2,57 \\
\hline 4 & 81 & 530 & 3,4 & 7 & 538 & 12,4 & 22,0 & 508 & 100 & 75 & 60 & 2,66 \\
\hline 6 & 107 & 630 & 0,4 & 7 & 538 & 11,8 & 21,8 & 508 & 96 & 75 & 55 & 2,44 \\
\hline 18 & 119 & 570 & 3,0 & 30 & 643 & 13,0 & 21,9 & 382 & 110 & 76 & 53 & 2,71 \\
\hline 19 & 118 & 500 & 1,9 & 30 & 643 & 13,4 & 22,0 & 382 & 113 & 76 & 56 & 2,87 \\
\hline 21 & 118 & 500 & 3,2 & 30 & 643 & 13,4 & 22,0 & 382 & 113 & 76 & 56 & 2,87 \\
\hline .22 & 120 & 500 & 3,1 & 30 & 643 & 13,4 & 22,0 & 382 & 113 & 76 & 56. & 2,87 \\
\hline 24 & 120 & 550 & 2,2 & 30 & 643. & 13,1 & 21,9 & 382 & 111 & 76 & 54 & 2,76 \\
\hline 25 & 107 & 550 & 2,5 & 30 & 643 & 13,1 & 21,9 & 382 & 111 & 76 & 54 & 2,76 \\
\hline 26 & 98 & 520 & 3,6 & 30 & 643 & 13,3 & 22,0 & 382. & 112 & 76 & 5.5 & 2,81 \\
\hline 65 & 130 & 100 & 2,5 & 134 & 141 & 14,6 & 18,7 & 874 & 113 & 80 & 171 & 5,78 \\
\hline $124^{I}$ & 109 & 70 & 1,8 & 167 & 72 & 13,7 & 21,4 & 656 & 105 & 87 & 107 & 4,18 \\
\hline $124^{I I}$ & 109 & 70 & 1,8 & 167 & 72 & 13,7 & 21,4 & 656 & 105 & 87 & 107 & 4,18 \\
\hline $386^{I}$ & 121 & 90 & 1,7 & 176 & 306 & 13,7 & 25,6 & 305 & 106 & 87 & 42 & 2,40 \\
\hline $386^{\text {II }}$ & 121 & 90 & 1,7 & 176 & 306 & 13,7 & 25,6 & 305 & 106 & 87 & 42 & 2,40 \\
\hline $111^{I}$ & 158 & 25 & 1,4 & 175 & 14 & 12,7 & 20,6 & 298 & 101 & 88 & 45 & 2,61 \\
\hline $111^{I I}$ & 158 & 25 & 1,4 & 175 & 14 & 12,7 & 20,6 & 298 & 101 & 88 & 45 & 2,61 \\
\hline 121 & 102 & 150 & 1,6 & 186 & 129 & 13,1 & 27,9 & 316 & 90 & 87 & 32 & 1,80 \\
\hline $703^{I}$ & 160 & 100 & 0,8 & 190 & 5 & 12,4 & 24,5 & 440 & 86 & 87 & 46 & 2,19 \\
\hline $703^{\text {II }}$ & 160 & 100 & 0,8 & 190 & 5 & 12,4 & 24,5 & 440 & 86 & 87 & 46 & 2,19 \\
\hline $703^{\text {III }}$ & 160 & 100 & 0,9 & 190 & 5 & 12,4 & 24,5 & 440 & 86 & 87 & 46 & 2,19 \\
\hline $703^{\text {IV }}$ & 160 & 100 & 0,9 & $190^{\circ}$ & 5 & 12,4 & 24,5 & 440 & 86 & 87. & 46 & 2,19 \\
\hline $183^{I}$ & 88 & 110 & 2,6 & 152 & 28 & 12,2 & 18,5 & 714 & 101 & 84 & 111 & 4,15 \\
\hline $183^{I I}$ & 88 & 110 & 2,8 & 152 & 28 & 12,2 & 18,5 & 714 & 101 & 84 & 111 & 4,15 \\
\hline
\end{tabular}




$$
\begin{gathered}
S \text { me } d \text { e } n \\
\text { Age class } 71-80
\end{gathered}
$$

\begin{tabular}{|c|c|c|c|c|c|c|c|c|c|c|c|c|}
\hline & & $\begin{array}{c}\text { Annual mean } \\
\text { increment }\end{array}$ & Stat & tion & & & & & $E$ & $\stackrel{S}{10^{-2}}$ & CVP & CVP $x S$ \\
\hline$n r$ & $\begin{array}{l}\text { alt. } \\
\text { m. }\end{array}$ & $\mathrm{m}^{3} /$ hectare & $n r$ & $\begin{array}{c}\text { alt. } \\
\text { m. }\end{array}$ & ${ }^{\circ} \mathrm{C}$ & ${ }^{\circ} \mathrm{C}$ & $\mathrm{mm}$ & days & $\%$ & ohm $\mathrm{cm}$ & U & $0,0 \times 0$ \\
\hline 156 & 180 & 2,1 & 17 & 185 & 14,4 & 27,6 & 404 & 105 & 83 & 0,42 & 51 & 21 \\
\hline 109 & 350 & 2,5 & 68 & 450 & 14,1 & 23,7 & 592 & 116 & 78 & 1,02 & 89 & 91 \\
\hline 108 & 335 & 6,2 & 64 & 380 & 14,4 & 22,9 & 445 & 120 & 78 & 1,18 & 73 & 86 \\
\hline 15 & 144 & 4,8 & 197 & 146 & 15,8 & 18,1 & 517 & 156 & 69 & 0,90 & 135 & 122 \\
\hline 8 & 70 & 6,8 & 215 & 70 & 15,6 & 17,3 & 791 & 162 & 68 & 1,15 & 218 & \\
\hline 105 & 350 & 1,3 & 66 & 363 & 14,8 & 24,6 & 512 & 122 & 76 & 0,33 & 79 & \\
\hline 85 & 378 & 6,2 & 99 & 230 & 15,1 & 22,4 & 566 & 128 & 74 & 0,86 & 100 & \\
\hline 86 & 352 & 2,4 & 97 & 280 & 15,1 & 22,7 & 582 & 127 & 74 & 0,58 & 101 & \\
\hline 77 & 215 & 2,5 & 119 & 385 & 15,4 & 21,5 & 771 & 146 & 73 & 0,81 & 163 & \\
\hline 171 & 260 & 1,9 & 5 & 335 & $.14,0$ & 25,4 & 418 & 107 & 84 & 0,40 & 58 & \\
\hline
\end{tabular}




$$
S \text { w } d \text { e } n
$$

Age class 81-90

\begin{tabular}{|c|c|c|c|c|c|c|c|c|c|c|c|c|}
\hline Samp I & & $\begin{array}{l}\text { Annual mean } \\
\text { increment }\end{array}$ & Stat & ion & $\mathbb{T}^{v}$ & $T_{a}$ & & & & $\frac{S}{10^{-2}}$ & c VP & CVPXS \\
\hline$n r$ & $\begin{array}{l}\text { alt. } \\
\text { m. }\end{array}$ & $\mathrm{m}^{3} /$ hectare & $\mathrm{nr}$ & $\begin{array}{l}\text { alt. } \\
\text { m. }\end{array}$ & & & mm & days & $\%$ & ohm cm & & \\
\hline 150 & 25 & 1,6 & 31 & 9 & 15,9 & 25,1 & 465 & 120 & 81 & 0,41 & 80 & 33 \\
\hline 152 & 70 & 2,6 & 19 & 40 & 15,5 & $27 ; 8$ & 512 & 110 & 82 & 0,55 & 72 & 40 \\
\hline 151 & 55 & 1,7 & 32 & 8 & 15,6 & 27,9 & 404 & 111 & 82 & 0,58 & 57 & 33 \\
\hline 153 & 10 & 1,6 & 33 & 9. & 15,6 & 26,9 & 533 & 114 & 82 & 0,48 & 80 & 38 \\
\hline 148 & 375 & 3,0 & 28 & 445 & 14,1 & 24,2 & 537 & 100 & 82 & 0,77 & 71 & 55 \\
\hline 147 & 405 & 1,2 & 29 & 450 & 13,4 & 23,8 & 555 & 96 & 81 & 0,49 & 67 & 33 \\
\hline 159 & 285 & 1,7 & 12 & 255 & 14,5 & 27,4 & 469 & 103 & 83 & 0,89 & 59 & 53 \\
\hline 160 & 335 & 2,2 & 12 & 255 & 14,2 & 27,3 & 469 & 100 & 83 & 0,50 & 56 & 28 \\
\hline 168 & 300 & 1,8 & 8 & 365 & 14,9 & 26,8 & 462 & 105. & 84 & 1,03 & 63 & 65 \\
\hline 169 & 260 & 3,2 & 8 & 365 & 15,1 & 26,9 & 462 & 108 & 84 & 0,72 & 65 & 47 \\
\hline 170 & 250 & 2,3 & 8 & $365^{\circ}$ & 15,2 & 27,0 & 462 & 109 & 84 & 0,62 & 66 & 41. \\
\hline 155 & 120 & 1,6 & 18 & 30 & 15,0 & 29,7 & 444 & 110 & 82 & 0,59 & 56 & 33 \\
\hline 173 & 185 & 2,2 & 7 & 220 & 14,4 & 27,5 & 405 & 9.7 & 84 & 1,19 & 48 & 57 \\
\hline 125 & 175 & 3,2 & 41 & 205 & 14,8 & 23,9 & 496 & 122 & 80 & 0,46 & 83 & 38. \\
\hline 130 & 310 & 4,1 & 41 & 205 & 14,0 & 23,6 & 496 & 113 & 80 & 0,65 & 74 & 48 \\
\hline 131 & 220 & 1,7 & 41 & 205 & 14,5 & 23,8 & 496 & 119 & 80 & 0,31 & 80 & .25 \\
\hline 134 & 300 & 1,6 & 39 & 410 & 14,3 & 24,3 & 571 & 126 & 80 & 0,28 & 94 & 26 \\
\hline 138 & 205 & 4,5 & 43 & 130 & 13,5 & 21,6 & 563 & 120 & 80 & 2,29 & 94 & 2.15 \\
\hline 144 & 360 & 3,2 & 26 & 400 & 14,5 & 24,9 & 557 & 110 & 81 & 0,61 & 80 & 49 \\
\hline 141 & 424. & 3,3 & 23 & 420 & 13,6 & 25,4 & 544 & 127. & 81 & 0,96 & 83 & 80 \\
\hline 140 & 423 & 2,8 & 23 & 420 & 13,6 & 25,4 & 544 & 127 & 81 & 0,74 & 83 & 61 \\
\hline 104 & 345 & 0,6 & 66 & 363 & 14,8 & 24,6 & 512 & 122 & 76 & 0,27 & 79 & 21 \\
\hline 11.5 & 220 & 2,6 & 71 & 220 & 14,8 & 24,6 & 507 & 120 & 77 & 0,76 & 78 & 59 \\
\hline 107 & 378 & 7,5 & 64 & 380 & 14,1 & 22,8 & 445 & 118 & 78 & $1,8.4$ & 70 & 129 \\
\hline 117. & 325 & 4,5 & 47 & 328 & 14,3 & 22,2 & 497 & 120 & 78 & 0,65 & 83 & 54 \\
\hline 119 & 293 & 3,7 & 48 & 320 & 15,0 & 24,1 & 506 & 115 & 79 & 0,62 & 79 & 49 \\
\hline 114 & 215 & 5,4 & 72 & 215 & 14,5 & 22,2 & 476 & 118 & 78 & 0,60 & 79 & 47 \\
\hline 116 & 254 & 3,4 & 52 & 165 & 14,8 & 24,6 & $4 \overline{8} 2$ & 120 & 78 & 0,47 & 75 & 35 \\
\hline 93 & 316 & 1,8 & 90 & 250 & 14,6 & 21,3 & 623 & 126 & 75 & $0,7.3$ & 112 & 82 \\
\hline 92 & 110 & 4,3 & 103 & 165 & 15,7 & 20,3 & 634 & 141 & 75 & 1,69 & 144 & 243 \\
\hline 94 & 240 & 2,0 & 88 & 400 & 15,1 & 22,4 & 614 & 125 & 75 & 0,96 & 1.08 & 104 \\
\hline 98 & 179 & 8,6 & 89 & 73 & 15,4 & $2 \dot{2}, 6$ & 471 & 128 & 76 & 0,79 & 87 & 69 \\
\hline 95 & 265 & 2,8 & 87 & 405 & 15,0 & 23,2 & 646 & 127 & 75 & 0,73 & 111 & 81 \\
\hline 81 & 473 & 1,8 & 93 & 160 & 13,1 & 22,3 & 710 & 114 & 74 & 0,39 & 98 & 38 \\
\hline 80 & 280 & 5,5 & 93 & 160 & 14,3 & 22,7 & 710 & 124 & 74. & 0,62 & 114 & 71 \\
\hline 79 & 200 & 3,4 & 96 & 193 & 16,1 & 22,7 & 680 & 144 & 73 & 1,11 & 141 & 157 \\
\hline
\end{tabular}




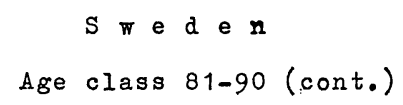

\begin{tabular}{|c|c|c|c|c|c|c|c|c|c|c|c|c|}
\hline \multirow{2}{*}{$\begin{array}{l}\text { Sample } \\
\mathrm{nr}\end{array}$} & \multirow{2}{*}{$\begin{array}{l}\text { e plot } \\
\text { alt. } \\
\text { m. }\end{array}$} & \multirow{2}{*}{$\begin{array}{l}\text { Annual mean } \\
\text { increment } \\
\mathrm{m}^{3} / \text { hectare }\end{array}$} & \multicolumn{2}{|c|}{ Station } & \multirow{2}{*}{$\begin{array}{l}{ }_{\mathrm{V}} \\
{ }^{\circ} \mathrm{C}\end{array}$} & \multirow{2}{*}{$\begin{array}{l}\mathrm{T}_{\mathrm{a}} \\
{ }^{\circ} \mathrm{C}\end{array}$} & \multirow{2}{*}{$\begin{array}{l}\mathrm{N} \\
\mathrm{mm}\end{array}$} & \multirow{2}{*}{$\begin{array}{c}G \\
\text { days }\end{array}$} & \multirow{2}{*}{$\begin{array}{l}E \\
\%\end{array}$} & \multirow{2}{*}{$\begin{array}{c}\mathrm{S} \\
10^{-2} \\
\mathrm{ohm} \mathrm{cm}\end{array}$} & \multirow[t]{2}{*}{ CVP } & \multirow[t]{2}{*}{ CVPXS } \\
\hline & & & $n r$ & $\begin{array}{c}\text { alt. } \\
\text { m. }\end{array}$ & & & & & & & & \\
\hline 78 & 350 & 1,8 & 96 & 193 & 15,1 & 22,3 & 680 & 135 & 73 & 0,64 & 126 & 81 \\
\hline 62 & 116 & 4,5 & 123 & 165 & 15,8 & 20,8 & 774 & 141 & 72 & 1,07 & 166 & 178 \\
\hline 58 & 172 & 5,6 & 123 & $165^{\circ}$ & 15,5 & 20,7 & 774 & 138 & 72 & 0,85 & 160 & 136 \\
\hline 61 & 203 & 3,2 & 121 & 225 & 15,6 & 21,3 & 755 & 139 & 73 & 1,06 & 156 & 165 \\
\hline 56 & 51 & 6,6 & 130 & 45 & 17,0 & 19,7 & 555 & 159 & 72 & 1,47 & 152 & 223 \\
\hline 57 & 46 & 6,1 & 128 & 50 & 16,7 & 20,0 & 658 & 155 & 72 & 1,27 & 170 & 216 \\
\hline 74 & 65 & 6,1 & 132 & 75 & 16,8 & 21,1 & 552 & 151 & 73 & 0,92 & 135 & 124 \\
\hline 68 & 25 & 5,7 & 140 & 15 & 15,7 & 18,8 & 468 & 149 & 73 & 1,85 & 118 & 218 \\
\hline 67 & 30 & 4,4 & 140 & 15 & 15,7 & 18,9 & 468 & 148 & 73 & 1,10 & 117 & 129 \\
\hline 51 & 201 & 3,7 & 163 & 250 & 15,1 & 18,6 & 556 & 139 & 70 & 1,34 & 122 & 163 \\
\hline 49 & 75 & 6,6 & 153. & 50 & 16,3 & 18,9 & 515 & 156 & 71 & 1,62 & 137 & 223 \\
\hline 47 & 131 & 6,8 & 160 & 180 & 16,3 & 19,1 & 655 & 155 & 71 & 0,87 & 171 & 149 \\
\hline 50 & 165 & 5,6 & 160 & 180 & 16,1 & 19,0 & 655 & 153 & 71 & 0,90 & 167 & 150 \\
\hline 45 & 185 & 6,6 & 159 & 185 & 16,1 & 19,7 & 714 & 153 & 71 & 1,12 & 176 & 197 \\
\hline 46 & 156 & 4,4 & 160 & 180 & 16,2 & 19,1 & 655 & 154 & 71 & 0,88 & 169 & 149 \\
\hline 39 & 200 & 6,9 & 185 & 37 & 14,1 & 17,5 & 833 & 138 & 69 & 0,69 & 178 & 123 \\
\hline 37 & 155 & 6,8 & 124 & 100 & 15,3 & 17,9 & 911 & 155 & $69^{\circ}$ & 0,63 & 231 & 146 \\
\hline 23 & 290 & 6,2 & 191 & 350 & 14,7 & 17,9 & 703 & 142 & 70 & 1,02 & 159 & 164 \\
\hline 17 & 166 & 6,1 & 193 & 140 & 15,8 & 18,1 & 652 & 155 & 69 & 1,09 & 169 & 184 \\
\hline 19 & 389 & 5,1 & 184 & 340 & 13,7 & 17,2 & 794 & 137 & 69. & 1,52 & 166 & 252 \\
\hline 11 & 150 & 5,0 & 214 & 110 & 14,6 & 16,4 & 812 & 158 & 68 & 1,04 & 216 & 227 \\
\hline 33 & 117 & 6,5 & 200 & 45 & 16,3 & 18,1 & .583 & 154 & 69 & 1,43 & 155 & 222 \\
\hline 5 & 40 & 5,2 & 222 & 7 & 16,6 & 17,3 & .562 & 170 & 68 & 2,48 & 173 & 429 \\
\hline
\end{tabular}




\begin{tabular}{|c|c|c|c|c|c|c|c|c|c|c|c|c|}
\hline \multirow{2}{*}{$\begin{array}{l}\text { Sample } \\
n r\end{array}$} & \multirow{2}{*}{$\begin{array}{l}\text { plot } \\
\text { alt. } \\
\text { m. }\end{array}$} & \multirow{2}{*}{$\begin{array}{l}\text { Annual mean } \\
\text { increment } \\
\mathrm{m}^{3} / \text { hectare }\end{array}$} & \multicolumn{2}{|c|}{ Station } & \multirow{2}{*}{$\begin{array}{l}{ }_{V}^{T} \\
{ }^{\circ} \mathrm{C}\end{array}$} & \multirow{2}{*}{$\begin{array}{l}\mathrm{T}_{\mathrm{a}} \\
{ }^{\circ} \mathrm{C}\end{array}$} & \multirow{2}{*}{ m } & \multirow{2}{*}{$\begin{array}{c}G \\
\text { days }\end{array}$} & \multirow{2}{*}{$\begin{array}{l}\mathrm{E} \\
\%\end{array}$} & \multirow{2}{*}{$\begin{array}{c}\mathrm{S} \\
10^{-2} \\
\text { ohm cm }\end{array}$} & \multirow[t]{2}{*}{ CVP } & \multirow[t]{2}{*}{ CVPxS } \\
\hline & & & $\mathrm{nr}$ & $\underset{\mathrm{m}}{\text { alt. }}$ & & & & & & & & \\
\hline 158 & 115 & 1,9 & 20 & 58 & 15,3 & 27,8 & 440 & 108 & 83 & 0,59 & 60 & 35 \\
\hline 145 & 530 & 1,5 & 25 & 440 & 14,4 & 24,0 & 458 & 99 & 81 & 0,47 & 61 & 30 \\
\hline 146 & 400 & 1,7 & 29 & 450 & 13,4 & 23,8 & 555 & 97 & 81 & 0,48 & 68 & 33 \\
\hline 161 & 410 & 1,6 & 12 & 255 & 13,8 & 27,2 & 469 & 96 & 83 & 1,10 & 53 & 27 \\
\hline 162 & 400 & 2,2 & 12 & 255 & 13,8 & 27,1 & 469 & 97 & 83 & 0,67 & 53 & 27 \\
\hline 163 & 275 & 1,6 & 12 & 255 & 14,6 & 27,5 & 469 & 104 & 83 & 1,09 & 60 & 30 \\
\hline 154 & 275 & 3,3 & 17 & 185 & 13,7 & 27,4 & 404 & 99 & 83 & 0,76 & 46 & 23 \\
\hline 167 & 450 & 2,2 & 11 & 375 & 14,0 & 27,4 & 453 & 95 & 84 & 1,79 & 51 & 26 \\
\hline 172 & 320 & 2,0 & 5 & 335 & 13,6 & 25,2 & 418 & 103 & 84 & 0,59 & 54 & 27 \\
\hline 174 & 230 & 2,8 & 7 & 220 & $14,1$. & 27,5 & 405 & 94 & 84 & 1,42 & 46 & 23 \\
\hline 165 & 170 & 3,0 & 13 & 210 & $1.4,9$ & 28,4 & 471 & 103 & 84 & 0,72 & 59 & 30 \\
\hline 166 & 170 & 2,7 & 13 & 210 & 14,9 & 28,4 & 471 & 103 & 84 & 0,94 & 59 & 30 \\
\hline 132 & 230 & 2,4 & 4.1 & 205 & 14,4 & 23,7 & 496 & 118 & 80 & 0,60 & 79 & 25 \\
\hline 133 & 340 & 4,2 & 41 & 205 & 13,8 & 23,6 & 496 & 112 & 80 & 0,60 & 72 & 36 \\
\hline .129 & 400 & 4,4 & 24 & 328 & 13,7 & 25,9 & 504 & 128 & 81 & 0,42 & 77 & 32 \\
\hline 143 & 300 & 2,6 & 26 & 400 & 14,9 & 25,1 & 557 & 113 & 81. & 0,54 & 84 & 42 \\
\hline 139 & 85 & 2,0 & 42 & 15 & 14,6 & 22,2 & 470 & 120 & 81 & 2,10 & 83 & 42 \\
\hline 136 & 290 & 2,6 & 38 & 400 & 14,3 & 25,3 & 474 & 126 & 81 & 0,44 & 76 & 33 \\
\hline 142 & 458 & 3,9 & 22 & 550 & 12,7 & 25,4 & 498 & 125 & 81 & 0,83 & 70 & 35 \\
\hline 110 & 389 & 5,2 & 68 & 450 & 13,9 & 23,6 & 592 & 113 & 78 & 0,66 & 85 & 43 \\
\hline 113 & 71 & 6,8 & 78 & 40 & 15,1 & 20,9 & 599 & 127 & 77 & 0,44 & 118 & 52 \\
\hline 120 & 176 & 6,2 & 51 & 130 & 15,5 & 25,4 & 522 & 124 & 79 & 0,91 & 87 & 44 \\
\hline 123 & 350 & 3,6 & 53 & 355 & 14,2 & 24,0 & 544 & 1.20 & 79 & 0,54 & 85 & 42. \\
\hline 122 & 350 & 3,2 & 53 & 355 & 14,2 & 24,0 & 544 & 120 & 79 & 0,36 & 85 & 31 \\
\hline 99 & 43 & 6,3 & 91 & 10 & 15,3 & 19,9 & 517 & 134 & 76 & 1,57 & 112 & 56 \\
\hline 97 & 304 & 6,1 & 89 & 73 & 14,6 & 22,2 & 471 & 118 & 76 & 0,72 & 77 & 39 \\
\hline 100 & 397 & 3,5 & 66 & 363 & 14,5 & 24,5 & 512 & 119 & 76 & 1,29 & 76 & 38 \\
\hline 87 & 156 & 3,3 & 101 & 122 & 16,6 & 22,5 & 548 & 144 & 74 & 1,76 & 120 & 60 \\
\hline 91 & 295 & 4,9 & 86 & 255 & 15,3 & 23,4 & 600 & 127 & 75 & 0,66 & 104 & 52 \\
\hline 83 & 445 & 2,6 & 81 & 600 & 13,6 & 22,8 & 676 & 118 & 75 & 0,62 & 99 & 50 \\
\hline 55 & 129 & 8,1 & 165 & 130 & 16,4 & 19,4 & 676 & 154 & 71 & 1,42 & 174 & 87 \\
\hline 73 & 40 & 3,9 & 133 & 18 & 17,2 & 20,7 & 545 & 154 & 73 & 0,98 & 141 & 71 \\
\hline 71 & 17 & 2,8 & 108 & 35 & 16,0 & 20,9 & 527 & 143 & 74 & 1,16 & 119 & 60 \\
\hline 64 & 62 & 6,7 & 134 & 60 & 17,0 & 21,0 & 599 & 153 & 72 & 1,02 & 148 & 74 \\
\hline 54 & 56 & 6,1 & 166 & 45 & 16,1 & 19,5 & 566 & 150 & 71 & 1,64 & 138 & 69 \\
\hline 53 & 82 & 6,9 & 168 & 70 & 16,7 & 19,1 & 540 & 161 & 71 & 1,36 & 150 & 75 \\
\hline
\end{tabular}




$$
\begin{gathered}
\text { S we de } n \\
\text { Age class } 91-100 \text { (cont.) }
\end{gathered}
$$

\begin{tabular}{|c|c|c|c|c|c|c|c|c|c|c|c|c|}
\hline $\begin{array}{l}\text { Sample } \\
\mathrm{nr}\end{array}$ & $\begin{array}{c}\text { e plot } \\
\text { alt. } \\
\text { m. }\end{array}$ & $\begin{array}{l}\text { Annual mean } \\
\text { increment } \\
\mathrm{m}^{3} / \text { hectare }\end{array}$ & $\mathrm{nr}$ & $\begin{array}{c}\text { tion } \\
\text { alt. } \\
\text { m. }\end{array}$ & $\begin{array}{l}{ }_{\mathrm{T}} \\
{ }^{\circ} \mathrm{C}\end{array}$ & $\begin{array}{l}\mathrm{T}_{\mathrm{a}} \\
{ }^{\circ} \mathrm{C}\end{array}$ & $\mathrm{mm}$ & days & $\%$ & $\begin{array}{c}\mathrm{S} \\
10^{-2} \\
\text { ohm cm }\end{array}$ & CVP & $C \dot{V P x S}$ \\
\hline 42 & 124 & 4,4 & 162 & 115 & 16,3 & 18,9 & 689 & 160 & 71 & 0,88 & 188 & 94 \\
\hline 41 & 200 & 4,0 & 159 & 80 & 15,0 & 19,0 & 798 & 149 & 71 & 1,39 & 185 & 93 \\
\hline 25 & 221 & 3,4 & 190 & 300 & 15,4 & 18,7 & 567 & 151 & 70 & 0,93 & 137 & 69 \\
\hline 22 & 340 & 6,0 & 191 & 350 & 14,4 & 17,9 & 703 & 140 & 70 & 0,74 & 154 & 77 \\
\hline 18 & 180 & 5,1 & 193 & 140 & 15,8 & 18,2 & 652 & 154 & 69 & 0,77 & 167 & 84 \\
\hline 24 & 229 & 7,4 & 196 & 220 & 15,6 & 18,7 & 573 & 152 & 69 & 1,53 & 139 & 70 \\
\hline 20 & 216 & 4,8 & 184 & 340 & 14,7 & 17,5 & 794 & 147 & 69 & 0,96 & 188 & 94 \\
\hline 12 & 145 & 5,0 & 218 & 145 & 15,7 & 18,1 & 639 & 159 & 68 & 1,52 & 166 & 83 \\
\hline 31 & 108 & 3,6 & 200 & 45 & 16,3 & 18,0 & 583 & 154 & 69 & 0,78 & 156 & 78 \\
\hline 30 & 133 & 3,0 & 200 & 45 & 16,2 & 18,1 & 583 & 153 & 69 & 1,32 & 153 & 77 \\
\hline 36 & 12 & 2,6 & 176 & 12 & 16,3 & 17,2 & 498 & 159 & 71 & 0,48 & 148 & 74 \\
\hline 9 & 147 & 5,1 & 186 & 100 & 15,3 & 17,8 & 911 & 162 & 69 & 1,14 & 243 & 122 \\
\hline 6 & 34 & 7,4 & 224 & 6 & 16,1 & 17,3 & 575 & 167 & 68 & 1,36 & 169 & 85 \\
\hline
\end{tabular}


S re d e n

Age class .101-110

\begin{tabular}{|c|c|c|c|c|c|c|c|c|c|c|c|c|}
\hline \multirow{2}{*}{$\begin{array}{l}\text { Sampl } \\
n r\end{array}$} & \multirow{2}{*}{$\begin{array}{l}\text { plot } \\
\text { alt. } \\
\text { m. }\end{array}$} & \multirow{2}{*}{$\begin{array}{l}\text { Annual mean } \\
\text { increment } \\
\mathrm{m}^{3} / \text { hectare }\end{array}$} & \multicolumn{2}{|c|}{ Station } & \multirow{2}{*}{$\begin{array}{l}{ }_{\mathrm{T}}^{\mathrm{v}} \\
{ }^{\circ} \mathrm{C}\end{array}$} & \multirow{2}{*}{$\begin{array}{l}\mathrm{T}_{\mathrm{a}} \\
{ }^{\circ} \mathrm{C}\end{array}$} & \multirow{2}{*}{$\begin{array}{c}\mathrm{N} \\
\mathrm{mm}\end{array}$} & \multirow{2}{*}{$\begin{array}{c}G \\
\text { days }\end{array}$} & \multirow{2}{*}{$\begin{array}{l}\mathrm{E} \\
\%\end{array}$} & \multirow{2}{*}{$\begin{array}{c}\mathrm{S} \\
10^{-2} \\
\text { ohm cm }\end{array}$} & \multirow{2}{*}{$\mathrm{CVP}$} & \multirow{2}{*}{ CVPxS } \\
\hline & & & $\mathrm{nr}$ & $\begin{array}{c}\text { alt. } \\
\text { m. }\end{array}$ & & & & & & & & \\
\hline 149 & 65 & $2 ; 6$ & 28 & 445 & 16,0 & 25,1 & 537 & 121 & 82 & 0,50 & 94 & 47 \\
\hline 157 & 130 & 2,7 & 19 & 40 & 15,2 & 27,7 & 512 & 104 & 82 & 0,58 & 67 & 34 \\
\hline 128 & 370 & 2,6 & 36 & 345 & 14,0 & $\cdot 25,8$ & 519 & 122 & 80 & 0,50 & 76 & 38 \\
\hline 126 & 275 & 1,5 & 37 & 240 & 15,0 & 25,8 & 521 & 127 & 80 & 1,40 & 85 & \\
\hline 135 & 340 & 3,5 & 38. & 400 & 14,0 & 25,1 & 474 & 123 & 81 & 0,57 & 73 & 37 \\
\hline 137 & 137 & 2,0 & 41 & 20.5 & 15,0 & 23,9 & 496 & 125 & 80 & 0,83 & 86 & 43 \\
\hline 124 & 45 & 3,1 & 57 & 70 & 15,8 & 24,0 & 560 & 123 & 79 & 0,47 & 100 & 47 \\
\hline 106 & 410 & 3,1 & 65 & 350 & 14,1 & 23,4 & 350 & 116 & 78 & 0,57 & 53 & 27 \\
\hline 111 & 445 & 6,0 & 64 & 380 & 13,7 & 22,7 & 445 & 115 & 78. & 0,99 & 67 & 34 \\
\hline 1.12 & 215 & 5,1 & 67 & 375 & 14,9 & 24,3 & 552 & 124 & 78 & $0,71$. & 91 & 46 \\
\hline 118 & 332 & 3,6 & 48 & 320 & 14,7 & 23,9 & 506 & 113 & 79 & 0,63 & 77 & 39 \\
\hline 96 & 385 & 3,4 & 87 & 405 & 14,2 & 23,3 & 646 & 120 & 75 & 1,32 & 98 & 49 \\
\hline 102 & 422 & 3,7 & 74 & 415 & 13,4 & 23,6 & 635 & 107 & 77 & 1,34 & 83 & 42 \\
\hline 82 & 435 & 2,6 & 81 & 600 & 13,7 & 23,5 & 676 & 117 & 75 & 0,67 & 96 & 48 \\
\hline 72 & 15 & 4,4 & 133 & 18 & 17,3 & 20,7 & 545 & 157 & 73 & 1,88 & 145 & 73 \\
\hline 75 & 135 & 1,5 & 132 & 75. & 16,3 & 20,9 & 552 & 145 & 73 & 1,78 & 127 & 64 \\
\hline 69 & 30 & 7,1 & 140 & 15 & 15,7 & 18,9 & 468 & 148 & 73 & 1,11 & 117 & 59 \\
\hline 63 & 25 & 4,7 & 171 & 18 & 16,7 & 18,9 & 559 & 158 & 71 & 0,76 & 154 & 77 \\
\hline 5.2 & 153 & 5,7 & 163 & 250 & 15,4 & 18,7 & 556 & 148 & 70 & 1,80 & 132 & 66. \\
\hline 44 & 140 & 5,9 & 160 & 180 & 16,2 & 19,1 & 655 & 155 & 71 & 1,53 & 170 & 85 \\
\hline 40 & 133 & 5,9 & 150 & 54 & 16,3 & 18,6 & 693 & 157 & 71 & 1,50 & 188 & 94 \\
\hline 38 & 125 & 8,4 & 181 & 75 & 16,0 & 18,0 & 898 & 163 & 69 & 1,31 & 249 & 125 \\
\hline 14 & 186 & 3,6 & 217 & 173 & 16,5 & 18,6 & 593 & 161 & 69 & 0,81 & 162 & 81 \\
\hline 32 & 117 & 5,6 & 195 & 172 & 16,4 & 19,1 & 574 & 157 & 69 & 0,78 & 148 & 74 \\
\hline 35 & 1.38 & 5,1 & 174 & 45 & 16,6 & 18,9 & 567 & 151 & 70 & 1,56 & 146 & 73 \\
\hline 27 & 40 & $3 ; 5$ & 228 & 15 & 16,2 & 17,6 & 517 & 171 & 68 & 1,07 & 154 & 77 \\
\hline 28 & 45 & 5,8 & 228 & 15 & 16,2 & 17,6 & 517 & 170 & 68 & 1,15 & 153 & 77 \\
\hline 10 & 150 & 6,2 & 186 & 100 & 15,3 & 17,8 & 911 & 156 & 69 & 1,03 & 234 & 117 \\
\hline 7 & 115 & 5,7 & 223 & 30 & 15,8 & 17,4 & 552 & 158 & 68 & 1,28 & 150 & 75 \\
\hline 3 & 96 & 7,7 & 219 & 75 & 15,9 & 17,2 & 690 & 165 & 68 & 1,76 & 199 & 100 \\
\hline 4 & 97 & 8,3 & 219 & 75 & 15,8 & 17,1 & 690 & 165 & 68 & 1,97 & 199 & 100 \\
\hline 1 & 95 & $6 ; 3$ & 220 & 90 & 16,2 & 17,4 & 646 & 172 & 68 & 3,66 & 195 & 98 \\
\hline
\end{tabular}


S w e. d e $n$

Age class 111-120

\begin{tabular}{|c|c|c|c|c|c|c|c|c|c|c|c|c|}
\hline $\begin{array}{l}\text { Sample } \\
n r\end{array}$ & $\begin{array}{l}\text { plot } \\
\text { alt. } \\
\text { m. }\end{array}$ & $\begin{array}{l}\text { Annual mean } \\
\text { increment } \\
\mathrm{m}^{3} / \text { hectare }\end{array}$ & $n r$ & $\begin{array}{c}\text { tion } \\
\text { alt. } \\
\text { m. }\end{array}$ & $\begin{array}{l}{ }_{\mathrm{T}}^{\mathrm{T}} \\
{ }^{\mathrm{O}} \mathrm{C}\end{array}$ & $\begin{array}{l}{ }^{T}{ }_{a} \\
{ }^{\circ} \mathrm{C}\end{array}$ & $\mathrm{mm}$ & days & $\%$ & $\begin{array}{c}\text { s } \\
10^{-2} \\
\text { ohm cm }\end{array}$ & CVP & CVPXS \\
\hline 164 & 305 & 2,0 & 11 & 375 & 15,0 & 27,6 & 453 & 103 & 84 & 0,43 & 59 & 25 \\
\hline 127 & 370 & 2,2 . & 36 & 345 & 14,0 & 25,8 & 519 & 122 & 80 & 0,80 & 76 & 38 \\
\hline 121 & 215 & 5,0 & 50 & 205 & 15,2 & 25,3 & 512 & 122 & 79 & 0,50 & 82 & 41 \\
\hline 101 & 328 & 2,0 & $70^{\circ}$ & 215 & 14,0 & 24,8 & 469 & 113 & 76 & 1,33 & 63 & 32 \\
\hline 89 & 185 & 4,1 & 98 & 260 & 16,0 & 23,0 & 687 & 137 & 74 & 0,95 & 135 & 68 \\
\hline 84 & 295 & 3,8 & 99 & 230 & 15,6 & 22,7 & 566 & 133 & 74 & 0,85 & 106 & 53 \\
\hline 88 & 235 & 4,2 & 102 & 350 & 15,4 & 21,0 & 602 & 142 & 75 & 1,19 & 131 & 66 \\
\hline 59 & 176 & 5,3 & 125 & 185 & 15,8 & 20,3 & 703 & 145 & 73 & 1,34 & 161 & 81 \\
\hline 60 & 160 & 2,4 & 120 & 165 & 16,0 & 21,2 & 642 & 140 & 73 & 0,79 & 138 & 69 \\
\hline 70 & 27 & 4,7 & 137 & 35 & 16,8 & 20,6 & 498 & 155 & 73 & 1,06 & 128 & 64 \\
\hline 76 & 65 & 7,9 & 105 & 80 & 16,4 & 20,8 & 534 & 149 & 73 & 1,64 & 127 & 64 \\
\hline 66 & 30 & 9,1 & 140 & 15 & 15,7 & 18,9 & 468 & 148 & 73 & 1,63 & 117 & 59 \\
\hline 65 & - 46 & 6,8 & 138 & 5 & 17,0 & 20,2 & 493 & 152 & 72 & 1,08 & 126 & 63 \\
\hline 48 & 140 & 7,0 & 160 & 180 & 16,2 & 19,1 & 655 & 155 & 71 & 1,14 & 170 & 85 \\
\hline 43 & 110 & 7,6 & 162 & 115 & 16,4 & 18,9 & 689 & 161 & 71 & 1,14 & 190 & 95 \\
\hline 26 & 211 & 4,1 & 190 & 300 & 15,4 & 18,7 & 567 & 152 & 70 & 0,72 & 138 & 69 \\
\hline 21 & 294 & 4,5 & 191 & 350 & 14,6 & 17,9 & 703 & 142 & 70 & 0,77 & 158 & 79 \\
\hline 16 & 350 & 3,9 & 194 & 290 & 14,8 & 17,9 & 625 & 146 & 69 & 2,37 & 145 & 73 \\
\hline 13 & 168 & 6,9 & 213 & 140 & 15,7 & 17,8 & 696 & 160 & 69 & 1,01 & 188 & 94 \\
\hline 34 & 152 & 5,7 & 170 & 97 & 15,8 & 19,2 & 530 & 149 & 70 & 1,23 & 126 & 63 \\
\hline 29 & 35 & 5,0 & 201 & 37 & 15,9 & 18,1 & 566 & 153 & 69 & 1,55 & 146 & 73 \\
\hline 2 & 95 & 5,6 & 220 & 90 & 16,2 & 17,4 & 646 & 172 & 68 & 0,90 & 195 & 98 \\
\hline
\end{tabular}

Age class $121-130$

$\begin{array}{rrrrrrrrrrrr}90 & 700 & 1,9 & 62 & 680 & 12,0 & 22,5 & 568 & 92 & 76 & 0,62 & 59 \\ 103 & 570 & 1,1 & 60 & 615 & 12,7 & 22,7 & 559 & 103 & 78 & 0,54 & 70\end{array}$

